MAURIDES DE MELO RIBEIRO

\title{
DROGAS E REDUÇÃO DE DANOS: \\ ANÁLISE CRÍTICA NO ÂMBITO DAS CIÊNCIAS CRIMINAIS
}

\author{
TeSe De Doutorado
}

Orientador: Prof. Dr. SÉrgio Salomão Shecaira

FACULDADE DE DIREITO DA USP

SÃO PAULO

2012 
MAURIDES DE MELO RIBEIRO

\section{DROGAS E REDUÇÃO DE DANOS: \\ ANÁLISE CRÍTICA NO ÂMBITO DAS CIÊNCIAS \\ CRIMINAIS}

Tese de Doutorado apresentada à Banca Examinadora da Faculdade de Direito da Universidade de São Paulo, como exigência parcial para a obtenção do título de Doutor em Direito, sob a orientação do Prof. Dr. Sérgio Salomão Shecaira

FACULDADE DE DIREITO DA USP

SÃO PAULO

2012 
Para Júlia e Marina, minhas redutoras de danos embora companheiras de riscos. 


\section{AGRADECIMENTOS}

Sou sinceramente grato a todos que, de alguma forma, se fizeram presentes nesse processo de aprendizado e construção que está retratado nesse trabalho. Continuo crendo, com Manuel de Barros, que "o melhor de mim sou eles".

Todavia, não posso deixar de dar especial destaque ao meu orientador e sempre amigo, Prof. Dr. Sérgio Salomão Shecaira, através de quem apresento minha gratidão a todos os amigos, professores e funcionários da Faculdade de Direito do Largo de São Francisco.

Também, nesse mesmo sentido, destaco a importância do Instituto Brasileiro de Ciências Criminais, IBCCrim, e o faço lembrando amigos como Alberto Silva Franco, Ranulfo de Mello Freire e Sérgio Mazina Martins e, ainda, os componentes da Comissão de Política Nacional de Drogas.

No aprendizado acerca da questão das drogas, minha linha de pesquisa, é impossível deixar de reconhecer o privilégio de ter compartilhado da experiência e da amizade de componentes do Conselho Estadual de Entorpecentes, CONEN, como Alberto Zacharias Toron, Sérgio Dario Seibel, Fabio Mesquita, Celi Cavallari, Lidia Rosemberg Aratangi, Marco Segre, Maria Alice Polo Araujo e Ana Noto, dentre tantos outros.

Merece especial destaque, a lembrança de operadores da saúde pública, médicos, psicólogos, redutores de danos, especialmente os integrantes da Reduc - Rede Brasileira de Redução de Danos e Direitos Humanos e da Aborda - Associação Brasileira dos Redutores de Danos, como Daniela Piconez, Domiciano Siqueira e Dênis Petuco.

Foi fundamental, ainda, a contribuição de todos os componentes da equipe da USP no projeto "Integração de Competências". $\mathrm{Na}$ área da saúde pública: Camila, Erica, Heloisa, Daniela e Bia e no direito: Rogério, Cristiano e Luciano.

Agradeço, muito especialmente, aos meus sempre amigos, Luigi e Nora, Tatá e Silvana, Kiki e Zeca, Lela e Silvio, Fernanda, Angelinha e, em Campinas, Carlão e Guilherme.

À família sempre presente, meus sinceros reconhecimentos nas pessoas de meus irmãos e cunhados, Maraisa e Neto, Mauricio e Fernanda, Dudu e Tânia e dos primos irmãos, Marcelo, Rogério, Beth, Marco Aurélio e Xan.

E, finalmente, serei eterno devedor da Shirley, que, em meio a tudo isso, me achou. E me devolveu para mim. 
${ }^{6} \mathrm{E}$ nos usos, nas plantas, nas águas, na terra, no vento. . . Estrumes. ... O diabo na rua, no meio do redemunho ..."

João Guimarães Rosa.

Grande sertão: veredas.

"Pleased to meet you

Hope you guessed my name, oh yeah

But what's confusing you

Is just the nature of my game

Just as every cop is a criminal

And all the sinners saints

As heads is tails

Just call me Lucifer

'Cause I'm in need of some restraint

So if you meet me

Have some courtesy

Have some sympathy, and some taste"

The Rolling Stones.

Sympathy for the Devil. 


\section{RESUMO}

Ribeiro, M. M. Drogas e redução de danos: análise crítica no âmbito das ciências criminais. 2012. Tese (Doutorado em Direito) - Faculdade de Direito, Universidade de São Paulo.

A Política Mundial de Drogas, traduzida no modelo proibicionista-belicista que se convencionou designar como "war on drugs", vem recebendo acerbas críticas dos mais variados setores e atores, nacionais e internacionais, que se ocupam da "questão das drogas". Há um relativo consenso no sentido de que o proibicionismo fracassou. Apesar de seu elevado custo econômico não conseguiu uma redução significativa da oferta do produto etiquetado de ilícito e, paradoxalmente, aumentou os riscos para aqueles cidadãos que se dispõem a continuar utilizando drogas, em razão da clandestinidade imposta às cenas de uso, produção, distribuição e comércio de psicotrópicos. Todavia, desde que os estados modernos passaram a formular políticas públicas para o equacionamento dessa questão, o modelo proibicionista-punitivo vem sendo utilizado de forma hegemônica. A mais promissora alternativa à política proibicionista surgiu na Saúde Pública e ganhou expressão definitiva a partir da epidemia de HIV/Aids. Trata-se da vertente de origem européia hoje conhecida como estratégias de redução de danos. Em breve síntese, a nova abordagem pretende que o indivíduo que use drogas o faça com os menores danos possíveis, tanto no plano pessoal quanto social. A presente tese procura analisar as perspectivas da política de redução de danos no âmbito das Ciências Criminais. Para tanto, investigou-se as potencialidades da nova abordagem numa perspectiva criminológica e, especialmente, de política criminal. A partir do exame de programas e ações concretas implementadas pelos agentes de saúde, buscou-se identificar eventuais impactos na criminalidade conexa às práticas de uso e comércio de drogas ilícitas. A hipótese objetivada é o exame da possibilidade dessa política alternativa transpor os limites da Saúde Pública para ser utilizada no campo da política criminal.

Palavras-chave: Política Criminal, Política de drogas, Drogas, Redução de Danos 


\section{SUMMARY}

Ribeiro, M. M. Drugs and harm reduction: critical analysis in the scope of criminal science. 2012. Thesis (Law Ph. D.) - Faculdade de Direito, Universidade de São Paulo.

The world's drug policy, conventionally described as "war on drugs" in the prohibitionistcombative model, has received stinging criticism from a great number of sectors and agents related to the "drugs issue", both in the national and international ambits. There is a relative consensus that prohibitionism has failed. Despite its elevated economic cost, it has not achieved any significant reduction in the offer of the products labeled illicit, and, paradoxically, it has raised the risks to those citizens who are willing to continue consuming drugs, as the scenarios for using, producing, distributing and commercializing psychotropic drugs have been made clandestine. However, since modern states began to formulate public policies in order to balance that issue's equation, the prohibitionistpunitive model has been hegemonically used. The most promising alternative to the prohibitionist policy emerged from Public Health and gained definitive expression with the breakout of the HIV/Aids epidemic. This is the European-originated line of thought known as harm reduction strategies. In short, the new approach intends that the individual suffers as little damage as possible, either personally or socially, when using drugs. The present thesis seeks to analyze the perspectives of harm reduction policies in the scope of Criminal Sciences. For this purpose, the potential of this new approach was studied from a criminological perspective and also especially from the perspective of criminal policy. By examining programs and concrete actions implemented by health agents, this work strove to identify the possible effects on criminality associated with the practice of consuming and commercializing illicit drugs. The intended hypothesis is the study of the possibility that this alternative policy might leap across the boundaries of Public Health and be used in the sphere of criminal policy.

Keywords: Criminal Policy, Drugs policy, Drugs, Harm Reduction 


\section{RÉSUMÉ}

Ribeiro, M. M. Drogues et réduction de dommages: analyse critique dans le cadre des sciences criminelles. 2012. Thèse (Doctorat en Droit) - Faculté de Droit, Université de São Paulo.

La politique Mondiale des Drogues, exprimée à travers le modèle prohibitioniste-beliciste conventionellement désigné comme "War on Drugs", est l'objet de critiques acerbes par les acteurs et secteurs les plus variés, nationaux et internationaux, qui s'occupent de "la question des drogues". Il existe un relatif consensus comme quoi le prohibitionisme a échoué. Malgré son coût économique élevé, il n’a pas abouti à une réduction significative de l'offre du produit désigné comme illicite et, paradoxalement, il a augmenté les risques pour les citoyens qui souhaitent continuer à consommer des drogues, à cause de la clandestinité imposée aux lieux de consommation, production, distribution et commerce des psychotropes, Néanmoins, depuis que les états modernes ont formulé des politiques publiques pour la formulation de cette question, le modèle prohibitioniste-punitif a passé à être employé de forme hégémonique. L'alternative la plus prometteuse à la politique prohibitioniste a gagné son expression définitive à partir de l'épidémie de HIV/Sida. Il s'agit de la tendence d'origine européenne connue présentement comme les stratégies de réduction des dommages. Brièvement, le nouvel abordage propose que l'individu qui utilise des drogues le fasse avec un minimum de dommages, sur les plans personnel et social. La Thèse présentement soumise cherche à analyser les perspectives de la politique de réduction des dommages dans le cadre des Sciences Criminelles. Pour cela, le potentiel de la nouvelle approche dans une perspective criminologique, particulièrement de politique criminelle, a été analysé. A partir de l'examen de programmes et d'actions concrètes entreprises par les agentes de santé, l'on a cherché à identifier les impactes éventuels sur la criminalité liée aux pratiques et commerce des drogues illicites. L'hypothèse proposée consiste à examiner la possibilité que cette politique alternative sapplique au delà des limites de la Santé Publique, pour être utilisée sur le terrain de la politique criminelle.

Mots clés: Politique Criminelle, Politique de drogues, Drogues, Réduction de dommages. 


\section{SUMÁRIO}

1. A POLÍTICA CRIMINAL E AS DROGAS ........................................................................ 13

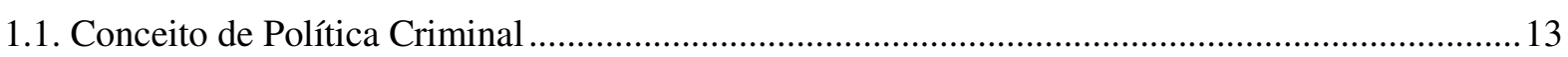

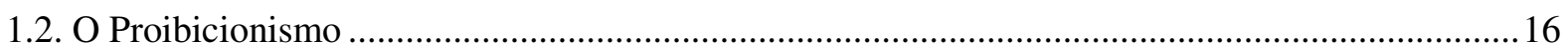

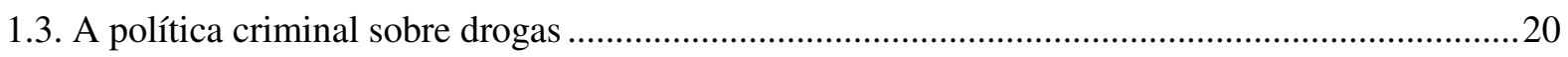

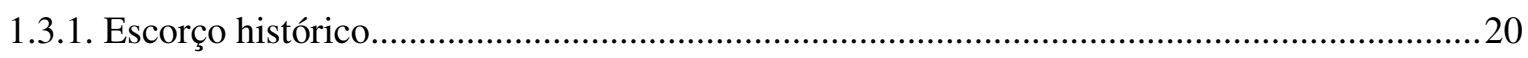

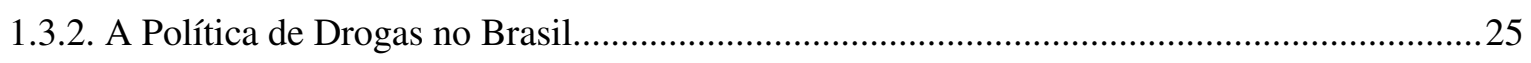

2. A POLÍTICA DE SAÚDE PÚBLICA E AS DROGAS...................................................... 31

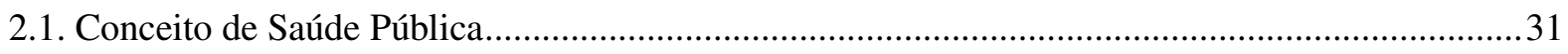

2.2. Saúde Pública e Violência............................................................................................................... 32

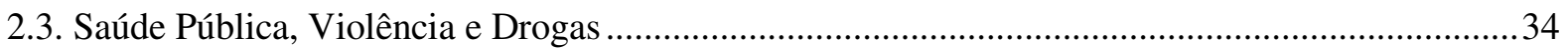

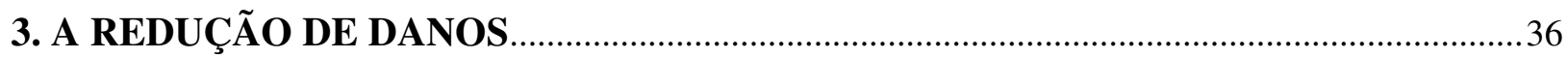

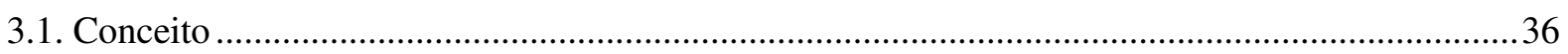

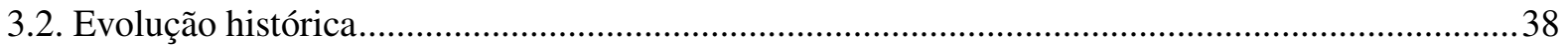

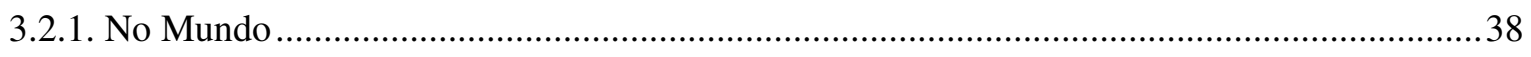

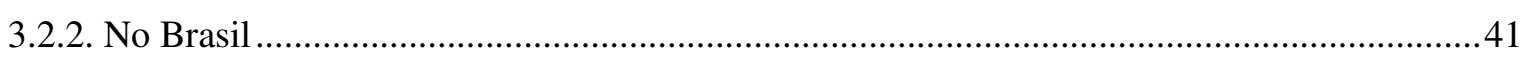

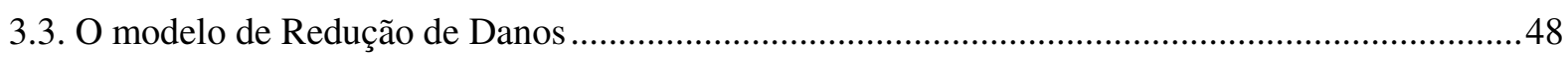

3.3.1. O arcabouço principiológico: Direitos Humanos - dignidade da pessoa humana...................48

3.3.2. A vulnerabilidade como critério de eleição das ações de Redução de Danos ..........................52

4. PROGRAMAS DE REDUÇÃO DE DANOS E AS DROGAS …......................................58

4.1. A Redução de danos: no marco do Proibicionismo .........................................................................58

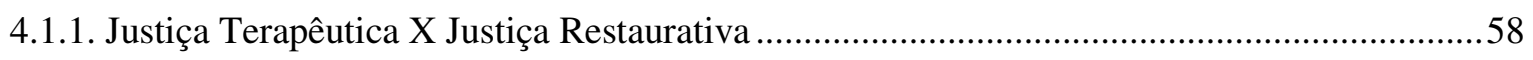

4.2. Programas de Redução de Danos para Cocaína/Crack ..................................................................67

4.2.1. O "higienismo" X consultórios de rua e locais de acolhimento ...............................................67

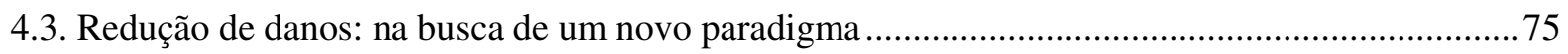

4.3.1. A descriminalização da Cannabis...................................................................................... 78

4.3.1.1. O estado atual do debate: o movimento antiproibicionista e suas propostas ...............78

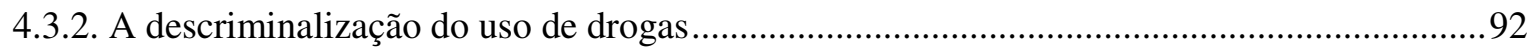

4.3.2.1. O modelo português ....................................................................................................92 


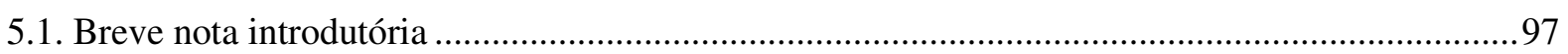

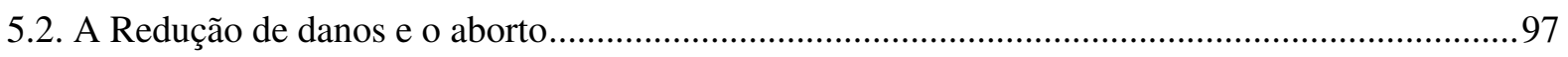

5.3. A Redução de danos e a terminalidade da vida: a ortotanásia ....................................................101

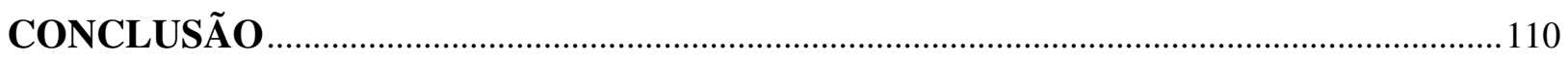

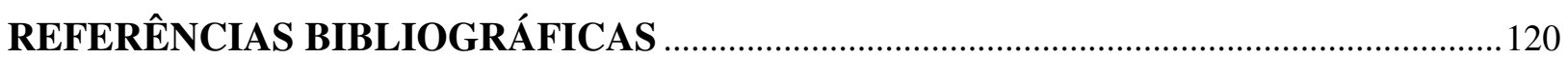

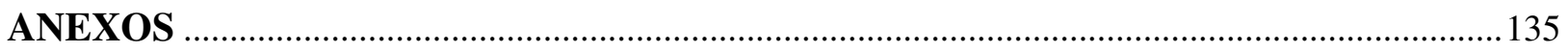

Anexo 1: PORTARIA No 1.059, DE 4 DE JULHO DE 2005

Anexo 2: POLÍTICA NACIONAL SOBRE DROGAS

Anexo 3: INTEGRAÇÃO DE COMPETÊNCIAS NO DESEMPENHO DA ATIVIDADE

JUDICIÁRIACOM USUÁRIOS E DEPENDENTES DE DROGAS

Anexo 4: CONSULTÓRIO DE RUA DO SUS

Anexo 5: CONSELHO FEDERAL DE MEDICINA

Anexo 6: ATENÇÃO HUMANIZADA AO ABORTAMENTO 


\section{INTRODUÇÃO}

Há mais de duas décadas que a saúde pública encampou o tema da violência como objeto de estudo em razão de ser ela causa de mortalidade, morbidades e comorbidades. E a chamada "questão das drogas" teve e tem relevante papel nessa pauta de investigações científicas empreendidas pelas ciências da saúde. Tanto que foi a pesquisa e a avaliação desse fenômeno que propiciou a formulação da política de redução de danos como uma proposta alternativa de abordagem para a "questão das drogas".

Sabemos que, apesar de todas as críticas, o proibicionismo-punitivo tem um papel hegemônico na formulação de políticas públicas nessa matéria. De fato, ele imperou, praticamente, como única alternativa de modelo de política pública até que a situação dos cidadãos usuários dessas substâncias se viu em muito agravada com o advento da epidemia de AIDS.

Constatou-se que o submundo no qual se desenvolve a cena de uso e comércio de drogas, notadamente em função da clandestinidade imposta pela criminalização da conduta, enfeixava inúmeras condições propícias à difusão da epidemia.

A partir dessa verificação epidemiológica, os agentes de saúde pública desenvolveram uma proposta de política pública para a questão das drogas que foi designada como estratégias de redução de danos. Trata-se de uma intervenção que se caracteriza pelo respeito a pessoa que usa drogas, agora vista como sujeito de direitos, e, por outro lado, dotada de um pragmatismo pois visa à melhora do quadro geral do cidadão usuário de drogas, sem que lhe seja exigida a renúncia ao consumo dessas substâncias, como condições para adesão ao programa de saúde.

Busca-se, através da presente pesquisa, investigar se a "Ciência Conjunta do Direito Penal" pode encampar esse novo modelo e seus fundamentos, trazidos pelas novas estratégias de saúde pública e, em caso positivo, estabelecer como se pode realizar a ampliação do conceito original para o âmbito das preocupações que formam o seu objeto próprio.

\footnotetext{
${ }^{1}$ DIAS, Jorge de Figueiredo. Questões fundamentais de direito penal revisitadas. São Paulo: Ed. Revista dos Tribunais, 1999. p. 49.
} 
Para tanto, no primeiro capítulo do trabalho, a pesquisa analisará, buscando estabelecer as bases teóricas para seu desenvolvimento, a política criminal na atualidade, seu conceito e, principalmente, sua evolução no que pertine com a chamada "questão das drogas".

No segundo capítulo busca-se compreender a evolução das políticas de saúde pública e as estratégias por ela adotadas ao incluir a violência como objeto de suas preocupações, até se chegar à sistematização das políticas de redução de danos.

Examinando-se as estratégias adotadas pela saúde pública com relação à violência poderemos extrair um modelo que permita transpor o paradigma da redução de danos do campo da saúde pública para o âmbito das Ciências Criminais, como um modelo alternativo na formulação de políticas criminais, notadamente na área das drogas, mas não necessariamente a ela restrita. Essa é a meta que norteará o desenvolvimento do terceiro capítulo da presente tese.

No quarto capítulo será realizada a análise de alguns programas de redução de danos, a partir de uma leitura criminológica de seu acervo de pesquisas, buscando inferir a percepção de seus operadores com relação às perspectivas criminológicas e de política criminal do modelo de política de saúde.

Finalmente, no quinto capítulo, o trabalho visa o exame da compatibilidade do modelo de redução de danos e seu arcabouço principiológico com as Ciências Criminais. Para tanto analisaremos possibilidades práticas de transposição e aplicação do modelo para o âmbito da Política Criminal e, extrapolando o campo de trabalho inicial, examinaremos a possibilidade de aplicação do modelo a outras hipóteses de fenômenos sociais multifacetados, cuja conduta se viu criminalizada, como, por exemplo, os casos de aborto ilícito.

Após a investigação propiciada pela revisão bibliográfica e pelo estudo de alguns programas de redução de danos, a partir de uma leitura criminológica, teremos estabelecidos os marcos teóricos e políticos que possibilitarão analisar os impactos da abordagem alternativa para a questão das drogas, formulada pela saúde pública, no âmbito das Ciências Criminais, notadamente na Criminologia e Política Criminal. 


\section{A POLÍTICA CRIMINAL E AS DROGAS}

\subsection{Conceito de Política Criminal}

A Política pode ser compreendida em múltiplos sentidos. Em linhas gerais, podemos conceituá-la como: "arte ou ciência de governar", "arte ou ciência da organização, direção e administração de nações ou Estados", "aplicação desta arte aos negócios internos da nação (política interna) ou aos negócios externos (política externa)”, "ciência política", "orientação ou método político", "série de medidas para obtenção de um fim",

Políticas públicas, por seu turno, é a expressão utilizada para designar os “programas de ação governamental visando a coordenar os meios à disposição do Estado e as atividades privadas, para a realização de objetivos socialmente relevantes e politicamente determinados"3. Como se depreende da própria definição, o Estado ordenará suas ações visando a consecução de seus objetivos político-sociais para, em conjunto com a sociedade, implementá-las de forma articulada.

Embora a definição dos fundamentos e finalidades de uma política pública seja função do Estado, evidentemente com a participação dos diversos atores sociais nela envolvidos, sua implantação requer o envolvimento de todos os setores interessados nos seus resultados, articulados numa rede que acompanhará todo o processo de execução das medidas podendo realizar as adequações e eventuais ajustes com vistas ao cumprimento das metas pré-estabelecidas.

No atual modelo constitucional, diante do reconhecimento de direitos sociais que impõe uma prestação positiva do Estado, pode-se afirmar que as políticas públicas têm como meta, em linhas gerais, a concreção dos direitos e garantias fundamentais, podendo para tanto adotar medidas de cunho intervencionista, sem se descurar, no entanto, de que essa mesma intervenção também estará condicionada e, portanto, limitada por esses mesmos direitos e garantias constitucionais.

\footnotetext{
${ }^{2}$ Conferir: HOUAISS, Antonio; VILLAR, Mauro de Salles. Dicionário Houaiss da língua portuguesa. Rio de Janeiro: Objetiva, 2001. p. 2.253.

${ }^{3}$ BUCCI, Maria Paula Dallari. Direito administrativo e políticas públicas. São Paulo: Saraiva, 2000. p. 241.
} 
Dentre as inúmeras demandas a cargo da intervenção estatal através de políticas públicas, a segurança e a criminalidade são temas recorrentes e presentes em todos os programas de governo. Apesar disso, o debate em torno das políticas públicas relativas a esses temas é inexistente ou superficial, esgotando-se, na maioria das vezes, na promoção de medidas repressivas. Há uma crença, constantemente realimentada pelos meios de comunicação de massa, na eficiência do direito penal e suas agências de controle social na manutenção da segurança pública e contenção da criminalidade.

Nesse passo, não avançamos para a concepção de um programa amplo e consistente que articule a adoção de políticas sociais em conjunto com políticas criminais, estrito senso. As políticas sociais, assim como a política criminal, são espécies do gênero políticas públicas e devem ser articuladas num programa de governo, cabendo a cada uma delas um papel determinado. As primeiras têm como meta a promoção de uma melhor qualidade de vida da população em geral, tornando efetivos os seus direitos constitucionais através de políticas de emprego, de capacitação profissional, de saúde e outras ações de promoção e tutela da dignidade humana. As medidas de natureza preventivas ou repressivas implantadas com vistas à tutela da segurança pública e contenção da criminalidade são opções político-criminais. Atuam diretamente no fenômeno criminal, prevenindo os fatores etiológicos da criminalidade e reprimindo-a quando lesionados ou postos em perigo concreto os bens juridicamente protegidos.

Há, portanto, um amplo conjunto de políticas públicas que deve ser implementado de forma articulada e sistemática para que seja possível atingir resultados exitosos relativamente ao fenômeno criminal.

Com relação à Política Criminal, propriamente dita, sua origem remota pode ser situada no marco do Iluminismo, tendo como referência histórica a clássica obra, Dos delitos e das Penas, de Beccaria, que é reconhecido como o fundador dessa disciplina. Contudo, é inegável que foram os alemães os que melhor sistematizaram e conferiram cientificidade a essa matéria, especialmente a partir de Franz Von Liszt e seu Programa de Marburgo, bem como com a concepção de seu modelo tripartido da "ciência conjunta do direito penal"4.

${ }^{4}$ DIAS, Jorge de Figueiredo. op. cit., p. 24. 
Contudo, o destaque conferido à Política Criminal na atualidade se deve, prioritariamente, às novas doutrinas alemãs, de concepção teleológico-funcionalistas, sobressaindo-se, dentre todas, a concepção desenvolvida por Claus Roxin, que teve o mérito de sistematizar a relação entre a Dogmática Penal e a Política Criminal.

No modelo proposto, a função do sistema penal, de caráter teleológico, seria o exame dos elementos concretos para a resolução dos problemas jurídicos, pautando-se pelas diretrizes político-criminais da teoria dos fins da pena ${ }^{5}$. O modelo tem sua base, portanto, nos parâmetros e finalidades de ordem político-criminais.

Para Roxin, a Política Criminal está "em um peculiar ponto médio entre a ciência e a estrutura social, entre a teoria e prática. Por uma parte baseia-se como ciência nos conhecimentos objetivos do delito, em suas formas de manipulação empírica e jurídica; por outra parte quer como uma forma de política estabelecer determinadas idéias ou interesses, tratando como teoria de desenvolver uma estratégia definitiva da luta contra o delito"6.

Por outro lado, ela não se resume a uma análise valorativa do fato e na eleição das respostas penais cabíveis visando a eficaz prevenção do delito, "senão também o conjunto dos aspectos fundamentais que segundo a Constituição e o Código Penal devem presidir a fixação e o desenvolvimento dos pressupostos da penalidade assim como da sanção"7.

Dessa forma, a Política Criminal mantém a Dogmática Penal em permanente contato com a realidade valendo-se, para tanto, dos aportes proporcionados pela Criminologia. Isso porque a Política Criminal "transforma a experiência criminológica, em opções e estratégias a serem assumidas pelo legislador e pelos poderes públicos" ${ }^{\text {. }}$.

Pode-se afirmar "que é à política criminal que pertence competência para definir, tanto no plano do direito constituído, como do direito a constituir, os limites da punibilidade; como, por outro lado, que a dogmática jurídico-penal não pode evoluir sem atenção ao trabalho 'prévio' de índole criminológica. Mas também este não pode evoluir

${ }^{5}$ ROXIN, Claus. Derecho penal: parte general. Madrid: Civitas, 1997. t. 1, p. 203-206.

${ }^{6}$ Id. Política criminal y estructura del delito: elementos del delito em base a la política criminal. Trad. Juan Bustos Ramírez y Hernán Hormazábal Malarée. Barcelona: PPU, 1992. p. 9.

${ }^{7}$ Id. La evolución de la política criminal, el derecho penal y el processo penal. Valencia: Tirant lo Blanch, 2000. p. 58.

${ }^{8}$ GARCÍA-PABLOS DE MOLINA, Antonio. Tratado de criminología. 2. ed. Valencia: Tirant lo Blanch, 1999. p. 207. 
sem uma mediação político-criminal que lance luz sobre as finalidades e os efeitos que se apontam à (e se esperam da) aplicação do direito penal."9

Portanto, numa perspectiva conjunta das Ciências Criminais, a política criminal funciona como o elo de ligação entre a dogmática penal e a realidade, fundada nos múltiplos subsídios trazidos pela criminologia, de tal sorte que "política criminal, dogmática jurídico-penal e criminologia são assim, do ponto de vista científico, três âmbitos autônomos, ligados porém, em vista do integral processo da realização do direito penal, em uma unidade teleológico-funcional. É a esta unidade que continua hoje justificadamente a convir o antigo conceito de V. Liszt de 'ciência conjunta do direito penal" ${ }^{, 10}$.

\subsection{O Proibicionismo}

A partir do século XVI, como decorrência do descobrimento do Novo Mundo e a possibilidade de contato com novas culturas e o estabelecimento de colônias ultramarinas, durante o período que ficou conhecido como das Grandes Navegações, os europeus foram apresentados a uma nova farmacopeia, grande número de ervas e especiarias, dentre elas substâncias psicoativas, que foram convertidas em valiosas mercadorias ${ }^{11}$ e introduzidas, progressivamente, em suas sociedades com finalidades médicas ou recreativas ${ }^{12}$.

\footnotetext{
${ }^{9}$ DIAS, Jorge de Figueiredo. op. cit., p. 49.

${ }^{10}$ Id., loc. cit.

${ }^{11}$ Quando da primeira publicação de O Capital, Engels, ao rebater as críticas dirigidas à teoria do valor proposta por Marx, termina por complementá-la chamando a atenção sobre o seu processo histórico e não, meramente, lógico. Primeiramente os produtores consumiam seus próprios produtos e as comunidades por eles formadas eram autossuficientes. No início das trocas de excedentes, o valor atribuído tinha relação com o tempo de trabalho agregado ao produto. Essas noções vão, por assim dizer, se desmaterializando à medida que a sociedade vai se tornando mais complexa e passa a promover intercâmbios comerciais entre famílias, comunidades, cidades, países, distanciando-se, cada vez mais, do local de produção de origem. Dessa maneira, os produtos se convertem em mercadorias. Finalmente, culmina o processo histórico com a transição para o dinheiro-metal. "O dinheiro tornou-se praticamente a medida decisiva do valor, e tanto mais, quanto mais variadas se tornaram as mercadorias objeto de comércio, quanto mais afastados eram os países donde provinham e quanto menos portanto se podia controlar o tempo de trabalho necessário para produzi-las". ENGELS, Friedrich. Aditamento ao Livro Terceiro de "O Capital". In: MARX, Karl. $O$ capital: crítica da economia política. Rio de Janeiro: Civilização Brasileira, 1974. v. 6, Livro Terceiro. O processo global da produção capitalista, p. 1025-1028.

${ }^{12}$ ESCOHOTADO, Antonio. O livro das drogas: usos e abusos, preconceitos e desafios. São Paulo: Dynamis Editorial, 1997.
} 
Esse comércio se intensificou a tal ponto que durante o século XIX, a Europa e os Estados Unidos conviviam com uma grande variedade de novas drogas, das quais pouco conheciam e com as quais tinham pouca ou nenhuma identificação cultural ${ }^{13}$.

O marco definitivo desse processo foram as Guerras do Ópio (1839 - 1841), a partir das quais os ingleses garantiram o monopólio internacional desse mercado, consolidaram o domínio britânico no Extremo Oriente e implementaram a prática comercial de substâncias psicoativas em larga escala ${ }^{14}$. Podemos dizer que tivemos, nesse primeiro momento histórico, a "guerra pela droga"15 que culminou com o domínio desse comércio pelas nações colonizadoras, notadamente Inglaterra e França, e a expansão do uso dessas substâncias no continente europeu.

Como dito, o "lastro cultural" existente nos povos de cujos países as substâncias psicotrópicas que foram introduzidas no Velho Mundo eram originárias, serviam como mecanismo de controle informal de seu consumo. A popularização do consumo desses "novos produtos" - dentro do contexto sócio-cultural de cada nação, - acarretou uma série de desdobramentos e impactos sociais (intoxicações agudas (overdoses), complicações crônicas à saúde), decorrentes da ausência daqueles dispositivos ${ }^{16}$.

Essa novidade culminou na elaboração de políticas públicas, com o intuito de solucionar os prejuízos causados pela massificação do consumo dessas substâncias. Desse modo, o consumo de drogas passou a ser considerado como causa de morbidade, merecendo ações de saúde como qualquer outra doença.

De qualquer sorte, as ações implementadas não tinham a proibição como seu eixo, e durante o século XIX, inúmeros compostos a base de ópio ou cocaína eram vendidos livremente nas boticas, e o uso com finalidades recreativas acontecia com relativa normalidade, dentro de bares, salões e reuniões sociais. Somente no período de transição para o século XX, que a conjugação de diversos fatores, com ênfase aos aspectos moralreligioso e étnico, contribuiu para o surgimento de um movimento que reivindicava a proibição do consumo de substâncias psicoativas, por entendê-la a melhor política para sanar os prejuízos clínicos, psicológicos e sociais dele derivados.

\footnotetext{
${ }^{13}$ MUSTO, David F. The american disease: origins of narcotic control. New York: Oxford University Press, 1987.

${ }^{14}$ PASSETTI, Edson. Das fumeries ao narcotráfico. São Paulo: EDUC, 1991.

${ }^{15}$ RODRIGUES, Luciana Boiteux de Figueiredo. Controle penal sobre as drogas ilícitas: impacto do proibicionismo no sistema penal e na sociedade. 2006. Tese (Doutorado) - Faculdade de Direito da Universidade de São Paulo, São Paulo, 2006. p. 249.

${ }^{16}$ ESCOHOTADO, Antonio. op. cit.
} 
Na perspectiva da moral-religiosa, o ideário cristão sempre condenou o consumo de plantas e fungos psicoativos, especialmente os outrora vinculados a rituais pagãos, como o cânhamo, a mandrágora, o ópio, a amanita muscaria, dentre outras ${ }^{17}$, e os vinculava a rituais diabólicos e a bruxarias, proscrevendo-os e perseguindo seus usuários ao longo de toda a Inquisição.

Com a Revolução Científica, e a invenção de novos processos físico-químicos, como a destilação, foi possível a obtenção de princípios ativos isolados que possibilitaram novas apresentações daquelas substâncias mais potentes que as obtidas nas culturas de origem. Vinculada a esse movimento, a nascente psiquiatria contemporânea passou a identificar nos psicotrópicos propriedades capazes de levar seu consumidor à degradação moral e ao vício, posteriormente denominados dependência ${ }^{18}$.

Além disso, a ideia de que o consumo de drogas induzia seus usuários à violência sempre esteve presente no imaginário popular ocidental ${ }^{19}$. Com esses ingredientes, a alternativa da proibição do consumo de drogas como estratégia de política pública estava presente de alguma forma em todas as nações no final do século XIX.

Nos Estados Unidos, porém, essa tendência ganhou um corpo teórico e se transformou em um movimento político estruturado. $O$ marco do nascimento do Proibicionismo, como sistema político, se deu no estado de Ohio, a partir de uma aliança entre as igrejas locais (católica e protestantes). Sob o slogan "ao badalar dos sinos das igrejas de Ohio, os saloons devem partir", o movimento tinha como sua plataforma política o fim do comércio de álcool, por julgá-lo a causa da degradação moral e física que acreditavam ter acometido o país.

A indústria do álcool crescera rapidamente nos Estados Unidos. A descoberta da refrigeração e da pasteurização, aliada ao desenvolvimento nos meios de transporte,

\footnotetext{
${ }^{17}$ ESCOHOTADO, Antonio. op. cit., p. 245.

${ }^{18}$ Id. Historia general de las drogas. Madrid: Alianza Editorial, 1995.

${ }^{19} \mathrm{Na}$ Idade Média, os cruzados se assustaram com os métodos de guerra de Hassan bin Sabbath e seus soldados usuários de haxixe. Passaram a chamá-los de haxixins ou assassinos (ashishins), e o termo se generalizou para denominar todo aquele que é capaz de atos de violência contra a vida humana com requintes de crueldade. No período colonial das Américas, o consumo do cânhamo pelos escravos, durante seus rituais religiosos, era associado à lascívia e ao descontrole (DÓRIA, Rodrigues. Os fumadores de maconha: efeitos e males do vício. In: BRASIL. Serviço Nacional de Educação Sanitária. Maconha: coletânea de trabalhos brasileiros. Rio de Janeiro: Ministério da Saúde, 1958. p. 2-3. No mesmo sentido: No mundo industrializado do século XIX, o consumo dessas substâncias entre as classes sociais mais pobres e excluídas, como os proletários, imigrantes e negros, foi cada vez mais relacionado às manifestações de raiva e violência que eclodiam de modo explosivo e desordenado em todo mundo desenvolvido daquele período (MUSTO, David F. op. cit.).
} 
propiciaram a ampla circulação dessas mercadorias, com novos saloons sendo abertos a cada instante. Nesses locais promovia-se o jogo, a prostituição e a dança, tudo a se opor ao espírito puritano que sempre marcou a sociedade estadunidense ${ }^{20}$.

Na segunda metade do século XIX, a mentalidade proibicionista se difundiu em vários campos da sociedade civil norte-americana. Em 1869, foi fundado o Partido Proibicionista. Surgiram diversas sociedades e ligas, como a Sociedade Nova-Iorquina para Supressão do Vício (1868), a Liga das Senhoras Cristãs pela Sobriedade (1873) e as Ligas Anti-Saloon (1893). Nas universidades, entidades como a Federação Científica pela Sobriedade (1879) foram criadas para estudar o problema e propor soluções com bases acadêmico-científicas. Editoras e jornais dedicados exclusivamente ao tema pautaram a discussão, que ganhou dimensão nacional, acerca da necessidade de banir o consumo do álcool do país. Além disso, o movimento soube se articular com outros movimentos sociais em ascensão, como a luta feminina pelo sufrágio universal e as campanhas antitruste ${ }^{21}$.

Nesse contexto cultural propício, já no início do século $\mathrm{XX}$, as nações, dentro do espírito sanitarista e do estado assistencial, passaram a legislar sobre o tema. Em 1906, os Estados Unidos aprovaram a Pure Food and Drug Act que exigia o detalhamento da composição dos medicamentos. Nesse mesmo ano, o hábito de fumar ópio foi proibido no país, ficando o uso restrito ao tratamento das doenças ${ }^{22}$.

Alguns anos mais tarde, o Harrison Narcotics Act (1914) determinou que a cocaína e o ópio fossem utilizados apenas com prescrição médica. Progressivamente o uso recreativo foi colocado na ilegalidade e o médico tornou-se o profissional responsável pela autorização do consumo de psicotrópicos.

O movimento atingiria seu ápice em 1920, quando o consumo de álcool foi banido dos Estados Unidos, após a aprovação da $18^{\mathrm{a}}$ Emenda à Constituição dos Estados Unidos ou Volstead $A c t^{23}$. Apesar do conhecido fracasso da medida, que ficou mundialmente conhecida como "Lei Seca", cujo único resultado concreto foi determinar o fortalecimento das máfias e dar início à internacionalização do crime organizado, o fato é que o modelo proibicionista-punitivo se consolidou de forma hegemônica, sendo apregoado como a

\footnotetext{
${ }^{20}$ ESCOHOTADO, Antonio. Historia general de las drogas, cit.

${ }^{21}$ RIBEIRO, Maurides de Melo; ARAƯJO, Marcelo Ribeiro. Política mundial de drogas ilícitas: uma reflexão histórica. In: SILVEIRA, Dartiu, Xavier da; MOREIRA, Fernanda Gonçalves. Panorama atual de drogas $e$ dependências. São Paulo: Atheneu, 2006. p. 459.

${ }^{22}$ ESCOHOTADO, Antonio. Historia general de las drogas, cit.

${ }^{23}$ MUSTO, David F. op. cit.
} 
única possibilidade de controle dessas substâncias, agora direcionado a outros psicotrópicos catalogados como ilícitos, como a cannabis, o ópio e a cocaína, ainda por razões morais e sanitaristas, mas, nessa nova cruzada, ganha especial destaque os fundamentos étnicos.

Pode-se, a partir desses aportes, concluir que o modelo proibicionista-punitivo tem por fundamento dois princípios: um de ordem moral-religiosa, que prega a abstinência como única possibilidade relacional dos indivíduos com essas substâncias, e outro de ordem higienista, que preconiza o ideal de um mundo livre de drogas, que, conjugados, determinam a proibição de qualquer modalidade de uso, comércio ou produção dos psicotrópicos etiquetados como ilícitos, condutas que passaram a ser tipificadas como crime e sancionados com penas privativas de liberdade e mesmo, em alguns países, penas corporais $^{24}$.

\subsection{A política criminal sobre drogas}

\subsubsection{Escorço histórico}

Quando falamos sobre política criminal relacionada à questão das drogas vemo-nos praticamente obrigados a refletir sobre o proibicionismo que, patrocinado no plano internacional pelos Estados Unidos da América, que por sua vez detém a hegemonia no concerto das nações, não encontrava, há até bem pouco tempo, nenhum contraponto à sua ideologia fundamentalista-puritana que se concretiza na chamada "guerra às drogas".

$\mathrm{Na}$ realidade, desde que os estados modernos passaram a se ocupar da "questão das drogas", com o propósito de formular políticas públicas para o seu equacionamento, o modelo proibicionista-punitivo vem sendo adotado de maneira quase unânime e praticamente sem questionamentos.

Engessando definitivamente o debate, as denominadas Convenções-Irmãs da ONU estabeleceram um sistema internacional de controle de algumas drogas catalogadas de ilícitas, reafirmando o proibicionismo como a política a ser seguida por todas as nações.

\footnotetext{
${ }^{24}$ RODRIGUES, Luciana Boiteux de Figueiredo. op. cit., p.46.
} 
A primeira dessas Convenções, realizada em Nova York no ano de 1961, recuperou e detalhou as determinações oriundas da Liga das Nações nos anos 20, cuidando, basicamente, de proscrever o ópio, a cannabis e a cocaína. A segunda, que se deu em Viena no ano de 1971, reafirmou o propósito proibicionista frente aos movimentos contraculturais dos anos sessenta, banindo o LSD e as novas drogas sintéticas. A terceira, novamente em Viena em 1988, ratificou e fortaleceu o modelo proibicionista-punitivo como instrumento de combate ao crescimento do crime organizado e suas novas estratégias delitivas, como a lavagem de capitais. Além disso, recrudesceu no tratamento punitivo para com o usuário dessas substâncias, recomendando expressamente a criminalização dessa conduta.

Posteriormente, em 1998, portanto dez anos após a assinatura da última das “convenções-irmãs”, a Assembléia Geral das Nações Unidas realizou uma Sessão Especial (UNGASS) dedicada à discussão da política mundial de drogas, na qual ratificou os tratados anteriores e colocou ao mundo um desafio: erradicar ou diminuir significativamente, até 2008, a produção e o consumo de drogas ilícitas no planeta.

Como decorrência dessa opção de mão única temos assistido a um duplo fracasso. De um lado não conseguimos uma redução significativa da oferta do produto etiquetado de ilícito e, por outro lado, aumentamos exponencialmente os riscos para aqueles cidadãos que, apesar de toda a repressão, se dispõem a continuar utilizando aquelas substâncias, seja para fins recreativos, seja com finalidades medicinais ou, até mesmo, em razão de terem desenvolvido dependência aos psicotrópicos ao longo do tempo de uso.

Novos fatores foram adicionados à questão com o fim da guerra fria. Após a derrocada do bloco socialista, simbolicamente representada pela queda do muro de Berlim, o embate ideológico é rapidamente substituído pela hegemonia das leis do mercado. Com a queda das barreiras nacionais e o acesso a novos mercados as perspectivas de expansão comercial atingiram proporções até então inimagináveis.

Paradoxalmente, esses mesmos fenômenos contribuíram para o fomento do comércio das substâncias psicoativas, agora num ambiente globalizado. A criminalidade transnacional fortalece-se nesse contexto dando margem à implementação oportunista de uma política declaradamente militar capitaneada pelos Estados centrais, notadamente os 
Estados Unidos da América. Na arguta análise de Salo de Carvalho 25 “o ‘inimigo global’ é redescoberto nos agentes do narcotráfico devido ao seu potencial de milícia, sua capacidade econômica e sua estrutura organizacional”.

Assim as pressões internacionais tornam-se cada vez maiores e, a partir dos anos 90, a política mundial sobre drogas experimenta uma escalada repressiva, empolgada por uma superexposição midiática da violência que terminou por banalizá-la, transformando-a em espetáculo de entretenimento, conjugada com uma resposta oficial meramente simbólica dada aos reclamos do "clamor público" pelos agentes políticos que vêem no tema uma oportunidade sem igual para propagandearem-se com finalidades meramente eleitoreiras.

A conjugação desses fenômenos tem provocado um recrudescimento nas respostas do sistema penal e processual penal, notadamente naquilo que diz respeito às concepções garantísticas desses ramos do Direito.

Num movimento inversamente proporcional à desregulamentação das relações econômicas temos assistido à superafetação dos mecanismos de controle do Estado sobre a totalidade de seus cidadãos. Esse novo sistema político, regido por um totalitarismo penal, termina por desembocar num estado policialesco que tem como instrumentos de "combate" à nova criminalidade transnacional a restrição e/ou a flexibilização de direitos constitucionalmente consagrados, quando não a supressão pura e simples das liberdades públicas e das garantias individuais dos cidadãos.

Mas, para além da afronta às liberdades individuais e aos postulados garantísticos de um direito penal moderno, a política proibicionista se revela igualmente controvertida quando se tem em conta que, apesar de alegadamente visar à tutela da saúde pública, paradoxalmente cria, com a proibição, maiores riscos à saúde física e mental dos cidadãos que eventualmente venham consumir as substâncias etiquetadas de ilícitas.

E isto se dá em decorrência da clandestinidade imposta pela própria proibição, fator que impedirá um controle de qualidade dessas substâncias aumentando a possibilidade de adulteração e o desconhecimento de sua real potência, causas mais frequentes das intoxicações agudas (overdoses) observadas em razão do uso. Além disso, é evidente, que todo o sistema de distribuição e consumo dar-se-á no chamado submundo, na clandestinidade,

\footnotetext{
${ }^{25}$ CARVALHO, Salo. A atual política brasileira de drogas: os efeitos do processo eleitoral de 1998. Revista Brasileira de Ciências Criminais, São Paulo, n. 34, p. 129, 2001.
} 
o que aumentará a falta de assepsia e a possibilidade de transmissão de doenças infectocontagiosas, especialmente a AIDS, com o compartilhamento de instrumentos destinados ao uso de drogas.

Também é a clandestinidade da distribuição e uso de drogas que geram maiores tensões nas relações daí decorrentes, aumentando os índices de criminalidade e violência, uma vez que os partícipes desse submundo são levados a delinqüir e, até mesmo, a participar do tráfico em razão de sua vulnerabilidade, da falta de instrumentos formais para a solução dos conflitos decorrentes do comércio ilícito ou, até mesmo, em troca de sua dose de manutenção.

Esse quadro se agrava ainda mais nas hipóteses de o usuário desenvolver uma dependência química uma vez que em decorrência dela haverá, na grande maioria dos casos, a quebra das relações interfamiliares e sociais provocando novos conflitos desencadeadores de violências e outras condutas desviantes e/ou delitivas.

Some-se a tudo isso que o usuário de drogas que eventualmente desenvolva uma dependência química apresentará uma resistência natural na busca de ajuda terapêutica uma vez que haverá de confessar a prática de um crime e, em razão de as respostas estatais à questão consistirem, em sua esmagadora maioria, nas sanções penais, o usuário dessas substâncias proscritas será naturalmente refratário a buscar ajuda.

Apesar de todas as críticas, o proibicionismo-punitivo imperou como única alternativa de modelo de política criminal até que a situação dos cidadãos usuários dessas substâncias se viu em muito agravada com o advento da epidemia da AIDS, no início dos anos oitenta.

Constatou-se que o submundo no qual se desenvolvia a cena do uso de drogas, notadamente as injetáveis, enfeixava inúmeros fatores propícios à difusão da epidemia. Nos anos oitenta houve a demonstração de que um dos principais vetores de transmissão do HIV era a prática de compartilhamento de seringas e agulhas entre os consumidores de drogas injetáveis. A partir dessa verificação epidemiológica os agentes de saúde pública passaram a desenvolver uma proposta de política pública para a questão das drogas que foi designada como estratégias de redução de danos.

A ótica da nova abordagem é a de que se o cidadão usa drogas ao menos que o faça com os menores danos possíveis à sua saúde, à sua vida de relação e, finalmente, à própria sociedade. 
A nova maneira de lidar com o tema causou grandes polêmicas desde então, notadamente em razão das ações objetivas que propõe e que contemplam, apenas a título de exemplo, desde trocas e desinfecção de seringas e agulhas a terapias de substituição (heroína/metadona, crack/cannabis, cocaína/folha de coca etc.).

Essas práticas foram logo identificadas pelas agências penais estatais como formas de auxílio, incentivo ou induzimento ao uso e comércio de psicotrópicos e seus operadores passaram a ser vítimas de uma perseguição impregnada de um moralismo que se julgava superado no fim do milênio.

Após inúmeros embates, a política de redução de danos ganhou prestígio mundial em razão de seus resultados práticos, atingindo, em inúmeros países incluindo o Brasil, o estatuto da oficialidade uma vez que integrada na Política Nacional sobre Drogas (PNAD), dentre outras, na área saúde pública, muito embora sua aplicação esteja muito aquém de suas reais possibilidades e a tônica oficial ainda seja de cunho majoritariamente proibicionista-punitivo.

Não obstante esse relativo avanço das políticas alternativas e o evidente fracasso do modelo proibicionista-belicista, o fato é que, findo o prazo demarcado pelas próprias convenções internacionais já citadas, durante a última reunião realizada em Viena, em março de 2009, com a finalidade de avaliar o cumprimento das metas estabelecidas em 1998, vale rememorar: a erradicação ou o significativo decréscimo da produção, distribuição e consumo de drogas ilícitas até o ano de 2008, a Comissão sobre Entorpecentes da ONU (CND) manteve a política punitiva-proibicionista sob a irrealista meta de, uma vez mais, eliminar ou minimizar significativamente a produção e o uso de drogas ilícitas até o ano de 2019.

Contudo, ficou patente que não há mais unanimidade em torno da proposta proibicionista, nem no âmbito da própria Organização das Nações Unidas, uma vez que instâncias como a Organização Mundial de Saúde (OMS) e UNAIDS encamparam em seus programas e defenderam abertamente as estratégias de redução de danos e, entre os países membros, formaram-se dois blocos, os países europeus e alguns países latino-americanos, dentre eles o Brasil, (simpatizantes de uma política mais tolerante sintetizada hoje nas chamadas estratégias de redução de danos) e, de outro lado, especialmente, os EUA, China e França, que capitanearam a manutenção do proibicionismo-punitivo. 
A história já nos demonstrou os graves malefícios provocados por esses modelos de controle total. É necessário termos sempre em mente a advertência de que o maior perigo da criminalidade nas sociedades modernas não é o crime em si mesmo, mas sim o de que a luta contra este acabe por conduzir tais sociedades ao totalitarismo ${ }^{26}$.

\subsubsection{A Política de Drogas no Brasil}

As menções mais remotas em nossa legislação pertinentes à questão das drogas não chegam a representar um verdadeiro sistema legal. A primeira dessas disposições remonta às Ordenações Filipinas, que no livro V, título 89 dispõe que "nenhuma pessoa tenha em sua casa para vender rosalgar branco, nem vermelho, nem amarelo, nem solimão, nem escamonéa, nem ópio, salvo se for boticário examinado e que tenha licença para ter botica, e usar do ofício" 27 . Essas Ordenações do Reino, até pela falta de um órgão judiciário local responsável pela sua aplicação, restavam distantes da realidade cotidiana da colônia e, no mais das vezes, seus conflitos eram solucionados por disposições locais como provimentos municipais.

Mesmo na fase Imperial ainda não se registra um arcabouço legislativo sobre o tema e, ainda que o advento do Código Criminal do Império, sancionado em dezembro de 1830, representasse a primeira sistematização da matéria, a temática das drogas continuou sendo objeto de posturas municipais como a expedida pouco antes pela Câmara do Rio de Janeiro, em 04 de outubro 1830, que proibia a "venda e o uso do pito de pango, bem como a conservação dele em casas públicas", ${ }^{28}$ dispositivo que é considerado como um marco proibicionista por ser "o primeiro ato legal de proibição de venda e uso da maconha no mundo ocidental",29.

\footnotetext{
${ }^{26}$ CHRISTIE, Nils. La industria del control del delito: la nueva forma del holocausto? Buenos Aires: Editores del Puerto, 1993.

${ }^{27}$ LUISI, Luiz. A legislação penal brasileira sobre entorpecentes: nota histórica. Fascículos de Ciências Penais, Porto Alegre, v. 3, n. 2, p. 152, 1990.

${ }^{28}$ DÓRIA, Rodrigues. op. cit., p. 2 e 14 . No mesmo sentido: BATISTA, Nilo. Política criminal com derramamento de sangue. Revista Brasileira de Ciências Criminais, São Paulo, n. 20, p. 131, 1997.

${ }^{29}$ MACRAE, Edward; SIMÕES, José Assis. Rodas de fumo: o uso da maconha entre camadas médias urbanas. Salvador: EDUFBA; CETAD/UFBA, 2000. p. 19.
} 
O Código Penal da República de 1890 proibia em seu artigo 159 o comércio de "substâncias venenosas", dando continuidade à tradição que remonta à matriz colonial que denota um matiz de delito profissional dos boticários ${ }^{30}$. Subsidiariamente, permanecem os controles locais exercidos por intermédio das posturas municipais, como a proibição da venda da maconha nas feiras de Penedo com o fito de se evitar perturbações da ordem ${ }^{31}$.

O marco inicial de uma sistematização legal fundamentada em acordos internacionais, que a partir daí será uma das características marcantes das legislações posteriores sobre drogas, será o Dec.11.481, de 10.02.1915, que determinou o cumprimento da Convenção firmada na Conferência Internacional do Ópio, realizada em Haia em 1912, e da qual o Brasil foi signatário. Seguiu-se depois um período de quase meio século em que vigorou o modelo de política criminal denominado por Nilo Batista de "modelo sanitário",32.

Nesse período foram implementadas inúmeras alterações legislativas com nítida preocupação sanitarista, todas patrocinadas em decorrência de compromissos assumidos em convenções internacionais, o que terminou por implantar um sistema médico-policial. Importa ressaltar que apesar de, nessa fase, terem sido introduzidas inúmeras medidas invasivas e cogentes com relação aos usuários de drogas (obrigatoriedade de tratamento, internação compulsória, interdição de direitos etc.), sua conduta não chegou a ser criminalizada.

De fato, a posse ilícita só foi criminalizada em 1932 (Dec. 20.930 de 11.01.32) e o consumo propriamente dito somente passou a integrar a lista de ações criminalizadas em 1938, através do Decreto-Lei 891, de 25.11.1938 ${ }^{33}$.

Contudo, a criminalização do consumo teria vida breve, pois que sobrevem o Código Penal de 1940 que revoga todos os dispositivos penais vigentes relacionados à matéria, e confere ao tema uma disciplina mais sóbria - não se trata aqui de trocadilho não só optando por descriminalizar o consumo como promovendo uma redução do número de verbos incriminadores, a ponto de fundir num mesmo dispositivo legal, o artigo 281, as condutas relativas ao tráfico e a posse ilícita. Segue-se daí um período no qual se arrefeceram as preocupações oficiais relacionadas à questão das drogas.

\footnotetext{
${ }^{30}$ BATISTA, Nilo. op. cit., p. 131.

${ }^{31}$ DÓRIA, Rodrigues. op. cit., p. 12.

${ }^{32}$ BATISTA, Nilo. op. cit., p. 131.

${ }^{33}$ KARAM, Maria Lúcia. Aspectos jurídicos. In: SEIBEL, Sergio Dario; TOSCANO JR., Alfredo (Orgs.). Dependência de drogas. São Paulo: Ed. Atheneu, 2001. p. 529.
} 
O novo catalizador que motivou a conjugação de fatores que convergiram para o estabelecimento da militarização da questão das drogas - isto no plano interno, uma vez que sempre é preciso ter em conta que o principal vetor que preside essas modificações são as convenções internacionais - será o golpe militar de 1964, que criará as condições propícias para o surgimento da política criminal que se denominou de modelo bélico ${ }^{34}$.

Já na primeira alteração legislativa introduzida pelo regime militar, o Decreto-lei 385, de 26 de dezembro de 1968, promulgado treze dias após a edição do malfadado Ato Institucional n. ${ }^{\circ}$ 5, foi alterado o artigo 281 do Código Penal para, além de outros aspectos recrudescedores, equiparar a conduta da pessoa que usa drogas à do traficante.

Situação que não será substancialmente alterada até o advento da Lei n. ${ }^{\circ} 6.368$, de 21 de outubro de 1976, que ficou mais conhecida como a Lei de Entorpecentes, que, sob o aspecto penal, permaneceu em vigência até o dia 09 de outubro de 2006, quando se encerrou a vacatio legis da atual Lei de Drogas. Não se pode negar, contudo, que, ao disciplinar a conduta do usuário (artigo 16) de forma distinta da do traficante (artigo 12), a Lei n. ${ }^{\circ}$ 6.368/76 representou, na época, um avanço ainda que tímido, uma vez que o sistema repressivo impregnado da ideologia de segurança nacional permaneceu reforçado.

Uma vez restabelecido o Estado Democrático de Direito, especialmente após o advento da Constituição da República de 1988, experimentamos uma breve fase que se apresentava com ares liberalizantes. Isso se deu a reboque das reformas institucionais e legislativas visando implementar mudanças naquilo que, à época, a imprensa se referia como "entulho autoritário".

O debate acerca de modelos alternativos ao proibicionismo ganha as ruas também em função de que estavam evidentemente revogados os dispositivos legais que impunham a censura prévia a respeito do tema drogas, sendo certo que, até então, sequer era possível a realização de uma conferência sem prévia autorização ${ }^{35}$. Nesse período, inicia-se um movimento pela alteração da Lei $n^{\circ}$ 6.368/76 tendo, momentaneamente, ganhado expressão a tese da descriminalização da posse para uso próprio.

Todavia, apesar desse contexto histórico interno propício a mudanças legislativas liberalizantes, o fato é que com o fim da guerra fria, simbolicamente representada pela

\footnotetext{
${ }^{34}$ BATISTA, Nilo. op. cit., p. 137.

${ }^{35}$ Essas autorizações eram conferidas pelos Conselhos Estaduais ou pelo Conselho Federal de Entorpecentes (CONEN e CONFEN). Os "especialistas" que as requeriam deveriam cumprir uma série de exigências prévias, dentre elas apresentar o texto integral da palestra a ser proferida. Obtida a chancela do Conselho o conferencista adquiria o status de Conferencista oficial sobre entorpecentes.
} 
queda do muro de Berlim, o embate ideológico é rapidamente substituído pela hegemonia das leis do mercado. Com a queda das barreiras nacionais, o acesso a novos mercados e as perspectivas de expansão comercial, atingiram proporções até então inimagináveis.

Esses mesmos fenômenos contribuíram para o fomento do comércio das substâncias psicoativas, agora num ambiente globalizado. E como não poderia deixar de ser, a criminalidade transnacional fortaleceu-se nesse contexto, dando margem à implementação oportunista de uma política declaradamente militar, capitaneada pelos Estados centrais, notadamente os Estados Unidos da América. Na arguta análise de Salo de Carvalho " ${ }^{36}$ 'inimigo global' é redescoberto nos agentes do narcotráfico devido ao seu potencial de milícia, sua capacidade econômica e sua estrutura organizacional".

Diante da expansão e fortalecimento das máfias globalizadas, as pressões internacionais tornam-se cada vez maiores e, a partir dos anos 90, a legislação penal sobre drogas experimenta uma escalada repressiva, empolgada, no plano interno, por uma superexposição midiática da violência que terminou por banalizá-la, transformando-a em espetáculo de entretenimento, conjugada com uma resposta oficial meramente simbólica dada aos reclamos do "clamor público" pelos agentes políticos, que veem no tema uma oportunidade sem igual para propagandearem-se com finalidades meramente eleitoreiras.

A convergência desses fenômenos, nos planos externo e interno, acabou por provocar um recrudescimento nas respostas do sistema penal e processual penal, notadamente naquilo que diz respeito às concepções garantísticas desses ramos do Direito. Numa razão inversamente proporcional à desregulamentação das relações econômicas, exigidas pela nova "ordem mundial", assistimos à superafetação dos mecanismos de controle do Estado sobre seus cidadãos. Esse novo sistema político, regido por um totalitarismo penal, terminou por desembocar num Estado Policialesco que tem como instrumentos de "combate" à nova criminalidade transnacional a restrição e/ou a flexibilização de direitos constitucionalmente consagrados, quando não a supressão pura e simples das liberdades públicas e das garantias individuais dos cidadãos.

São os princípios estruturantes dessa nova "ordem mundial" que deram novo rumo à produção legislativa exasperando, ainda mais, o tratamento proibicionista-punitivo na disciplina relativa às drogas etiquetadas de ilícitas, como a chamada lei dos crimes hediondos, Lei n. ${ }^{\circ}$ 8.072, de 25.07.90, ou a Lei n. 9.034, de 03 de maio de 1995,

${ }^{36}$ CARVALHO, Salo. op. cit., p. 129. 
enunciando em seu preâmbulo, eufemisticamente, que "dispõe sobre a utilização de meios operacionais para a prevenção e repressão de ações praticadas por organizações criminosas" quando, na realidade institucionaliza um sem número de ações policiais arbitrárias; a Lei n. ${ }^{\circ}$ 9.613, de 03 de março de 1998, que, sempre em atenção a imposições alienígenas, veio dispor sobre os chamados crimes de lavagem de dinheiro e, culminando a escalada punitivista, a Lei n. ${ }^{\circ} 10.409$, de 11 de janeiro de 2002 que tinha como finalidade substituir a antiga Lei de Entorpecentes (Lei 6.368/76) mas que, já de saída, foi de tal forma desfigurada por vetos que entrou em vigor já absolutamente comprometida em sua eficácia.

Em vista disso, o Poder Executivo encaminhou ao Congresso Nacional um projeto de lei integrativo que visava suprir as lacunas decorrentes dos vetos impostos à nova Lei de Tóxicos (projeto $\mathrm{n}^{\circ}$ 6.108/02). Esse novo processo legislativo acabou por dar ensejo à apresentação de uma emenda substitutiva global que reescreveu toda a matéria disciplinada pela Lei n ${ }^{\circ} 10.409 / 2002$, não se limitando aos dispositivos anteriormente vetados.

Surge daí a Lei $n^{\circ} 11.343$, de 23 de agosto de 2006, a nova Lei de Drogas ${ }^{37}$, que embora tenha mantido a criminalização da conduta do mero uso de substâncias psicoativas, optando por promover uma descarcerização da sanção penal cominada, não se pode negar que tenha introduzido avanços, notadamente no que diz respeito ao expresso reconhecimento das estratégias de redução de danos, aproximando a política nacional de drogas ao modelo europeu, que se caracteriza pela adoção de uma política proibicionista moderada. ${ }^{38}$

Dentre as inovações liberalizantes, por reduzirem o controle penal sobre o uso de drogas, destacam-se, além da descarcerização da posse para uso próprio (artigo 28), a equiparação dessa conduta à daquele que planta para consumo pessoal (art. 28, § 1o.), a redução da pena para a hipótese de consumo compartilhado de droga ilícita ou, como era conhecido nos meios forenses, o "cedente eventual” (art. 33, § 3o.), conduta anteriormente

\footnotetext{
${ }^{37}$ O presente trabalho não visa o exame das modificações introduzidas pela nova Lei de Drogas. Todavia, é inegável que a nova Lei de Drogas adota critérios mais científicos e que lhe conferem maior precisão, até do ponto de vista terminológico. A própria finalidade estabelecida em seu pórtico, vale lembrar, a instituição do Sistema Nacional de Políticas Públicas sobre Drogas - Sisnad e, não mais como dispunham as leis que a precederam, criar medidas de prevenção e repressão ao tráfico ilícito e uso indevido de substâncias entorpecentes, já sinaliza a adoção de novos rumos e metas. E mais, a adoção da palavra droga para designar as substâncias psicotrópicas, ou ainda, o estabelecimento de uma clara diferenciação da pessoa que usa drogas para o dependente químico, são aspectos que, por si só, revelam consideráveis modificações nos critérios adotados pelo legislador ao fazer suas opções político-legislativas.

${ }^{38}$ RODRIGUES, Luciana Boiteux de Figueiredo. op. cit., p. 249.
} 
equiparada ao tráfico, além da abolitio criminis com relação à conduta daquele que utiliza local ou bem de sua propriedade ou posse, por qualquer título, para o uso de substâncias psicotrópicas, conduta que também era equiparada ao tráfico na revogada Lei de Entorpecentes, conforme o inciso II do $\S 2^{\circ}$ do artigo 12 da Lei $n^{\circ} 6.368 / 76$, e que, na Lei $\mathrm{n}^{\circ} 11.343 / 06$, não se viu mais tipificada, restando, tão somente, a criminalização daquela utilização de imóveis e bens para o tráfico de drogas, consoante a exata dicção do inciso III do $\S 1^{\circ}$ do artigo 33 da nova Lei de Drogas.

Há de ser destacado ainda outro fundamental aspecto, que em geral tem passado despercebido dos comentaristas da nova lei, que é a adoção de balizamentos éticos que representam importante avanço principiológico e permeiam toda a formulação da nova legislação, afastando-a da famigerada doutrina de segurança nacional, que era o substrato ético-político adotado pelas legislações anteriores, opção que aproxima a nova lei de drogas do sistema de proteção dos direitos humanos, fundamentos que lastreiam as estratégias de redução de danos.

Nesse sentido, importa ressaltar que a nova legislação prevê expressamente como fundamentos: "o respeito aos direitos fundamentais da pessoa humana, especialmente quanto à sua autonomia e à sua liberdade" (art. $4^{\circ}$. inciso I); "o respeito à diversidade e às especificidades populacionais existentes" (inciso II); além da necessidade do "fortalecimento da autonomia e da responsabilidade individual em relação ao uso indevido de drogas", no seu art. 19, III. Essa nova diretriz ético-política não pode ser vista apenas como um enunciado abstrato de caráter programático uma vez que estabelece as metas de política criminal para a matéria e haverá de ser observada pelos intérpretes e operadores do direito penal como parâmetro para a solução de conflitos e antinomias que se apresentarem na casuística a partir de sua vigência. 


\section{A POLÍTICA DE SAÚDE PÚBLICA E AS DROGAS}

\subsection{Conceito de Saúde Pública}

A definição clássica, comumente aceita pelos estudiosos da saúde pública, é atribuída a Winslow que a enunciou no ano de 1920. Esse pesquisador pioneiro na área da saúde pública entendia que sua área de conhecimento era " a arte e a ciência de prevenir a doença, prolongar a vida e fomentar a saúde e a eficiência, mediante o esforço organizado da comunidade" 39 .

A crítica que foi lançada ao conceito repelia a vaguidade de seus termos que lhe confere uma amplitude que resultaria na sua inexequibilidade, posto que, com base nele poderíamos transformar qualquer problema, individual, social ou mesmo de saúde, em problema de saúde pública.

Na verdade, a definição de saúde pública não se dá através de um conceito analítico, em razão de sua dimensão multifacetária, e sim a partir da delimitação de seu campo de atuação.

Dessa forma, para que um problema de saúde possa ser considerado um problema de saúde pública, seria necessário o preenchimento de três requisitos, segundo Nathan Sinai: "1) representar causa freqüente de morbidade e mortalidade; 2) existirem métodos eficientes para a sua prevenção e controle; 3) esses métodos não estarem sendo adequadamente empregados pela sociedade" ${ }^{, 4}$.

A esses requisitos delimitadores do campo da saúde pública destacados, o Prof. Oswaldo Paulo Forattini acrescenta uma quarta condição: “ao ser objeto de campanha destinada a erradicá-lo, ocorrer sua persistência além do prazo previsto" ${ }^{41}$.

\footnotetext{
${ }^{39}$ PEREIRA, José Carlos. Problema social e problema de Saúde Pública. In: TEMAS IMESC: sociedade, direito, saúde. São Paulo: IMESC, 1984.

${ }^{40}$ Apud, FORATTINI, P. Oswaldo. Epidemiologia geral. São Paulo: EDUSP, 1976. p. 60.

${ }^{41}$ Id., loc. cit.
} 


\subsection{Saúde Pública e Violência}

Apesar de o fenômeno da violência subsumir-se aos critérios delimitadores do campo de atuação da saúde pública (especialmente os três primeiros requisitos apontados anteriormente) o fato é que, para encampá-lo como objeto de seu interesse, a saúde pública necessitou promover uma nova reconfiguração de suas atribuições.

O grande marco institucional para que a saúde pública assumisse a questão da violência como uma de suas prioridades foi a orientação da Organização Mundial de Saúde (OMS) que, por meio da resolução 49.25, estabeleceu expressamente essa meta como sendo sua atribuição ${ }^{42}$. Essa postura do principal organismo internacional da área foi justificada, principalmente, pelo crescimento epidêmico da mortalidade por causas externas, nas últimas décadas, aliado à falência do modelo baseado, exclusivamente, nas agências estatais de controle penal.

Mas não só - a violência está associada ainda ao aumento da morbidade física e mental das populações vulneráveis. Em nosso país os fatores externos ocupam, cada vez mais, lugar de destaque como causas de óbito, sendo certo que em 1997 os homicídios passaram a figurar como a principal causa de morte precoce.

Os trabalhos de referência nessa área destacam que só é possível encampar o tema da violência como preocupação do campo da saúde pública se adotarmos uma concepção ampliada dessa área, nela se inserindo "tudo o que significa agravo e ameaça à vida, às condições de trabalho, às relações interpessoais, e à qualidade da existência",43 .

Dessa forma, para considerar a violência como um problema de saúde pública devemos ter em conta suas conseqüências para o conjunto social e não apenas na perspectiva do indivíduo, sendo que, a partir desse enfoque, fica evidenciado que as estratégias privilegiadas para seu enfrentamento são de natureza preventiva e interdisciplinar. Faz-se necessário, portanto, que a eleição das ações adequadas sejam precedidas de um planejamento que considere não só fatores objetivos, como, por exemplo, a freqüência e a distribuição da violência na população, mas que também e

\footnotetext{
${ }^{42}$ PERES, M. F. T. Prevenção e controle: oposição ou complementaridade para a redução da violência. Sociedade Brasileira para o Progresso da Ciência, 2008. Disponível em: <www.sbpcnet.org.br/>.

${ }^{43}$ MINAYO, Maria Cecília de Souza; SOUZA, Edinilsa Ramos de. É possível prevenir a violência? Reflexões a partir do campo da saúde pública. Ciências e Saúde Coletiva, Rio de janeiro, v. 4, n. 1, p. 7-23, 1999.
} 
principalmente identifique os fatores de risco determinantes da vulnerabilidade daqueles grupos, para que se formulem as medidas e estratégias necessárias para sua prevenção.

As ações de saúde, portanto, devem atuar nos fatores de vulnerabilidade buscando evitar a ocorrência da violência e, consequentemente, promovendo a saúde. É, portanto, evidente que precisamos conhecer os aspectos etiológicos, os dispositivos causais geradores da violência numa dada população, para que possamos formular intervenções antecipadas que impeçam sua ocorrência.

A saúde pública trabalha já tradicionalmente com três níveis de prevenção. $\mathrm{Na}$ chamada prevenção primária, as estratégias adotadas visam a promover a saúde e sua proteção com a finalidade de evitar a ocorrência do agravo. O foco dessa fase de medidas, portanto, concentra-se nos fatores de risco, buscando reduzir a exposição ou criar e fortalecer mecanismos de proteção a esses agentes causais. A prevenção secundária, por seu turno, compreende estratégias que operem nos casos de ocorrência do agravo, embora esse não esteja consolidado, tendo como objetivo a redução dos danos causados pela violência. Finalmente, a chamada prevenção terciária se dá quando é necessária a adoção de medidas de tratamento e reabilitação de casos de violência já consumada.

Nesse passo, podemos concluir que a transposição desse modelo para o fenômeno da violência não se dará sem o esforço conjunto de todos os setores e agentes envolvidos nessa empreitada, posto que deveremos considerar não apenas os efeitos da violência em vítimas determinadas mas, especialmente, o fenômeno em si mesmo, nas suas variadas formas de expressão no contexto social.

O grande desafio, portanto, na formulação de políticas de prevenção da violência consiste, exatamente, na existência dessa multiplicidade de fatores que implicam na necessidade de uma estratégia capaz de coordenar o conjunto de ações necessárias ao enfrentamento do fenômeno nos seus diferentes níveis de determinação.

As políticas de saúde pública, de assistência social, de educação, dentre outras cuja necessidade seja diagnosticada em função da diversidade e especificidades locais, devem ser adotadas conjuntamente com as medidas de política criminal e não como tradicionalmente vêm sendo aplicadas, de forma desarticulada e priorizando a abordagem punitiva. No campo da violência, é necessária uma interdisciplinaridade e complementaridade das abordagens eleitas na formulação das políticas de prevenção. Essa estratégia de ações, interdisciplinares e inter setoriais, articuladas numa mesma política de 
prevenção à violência objetiva, em última análise, não apenas a sua meta específica mas, fundamentalmente, uma atenção integral às populações vulneráveis expostas a esses fatores de risco, numa perspectiva de promoção dos direitos humanos.

\subsection{Saúde Pública, Violência e Drogas}

Se, com relação à violência, verificamos que a Saúde Pública preconiza um sistema complexo de intervenções multidisciplinares para as abordagens preventivas, quando adicionamos a variável droga, embora os especialistas concordem que álcool e drogas frequentemente têm papel importante nos eventos violentos, há muita incerteza quanto às explicações causais. Vale dizer, não nos é possível saber se, em estado de abstinência, essas mesmas pessoas não teriam cometido os mesmos atos violentos.

Por outro lado, a ilegalidade imposta pela criminalização do uso e comércio de algumas dessas substâncias etiquetadas como ilícitas adiciona novos fatores que potencializam as incertezas, especialmente se considerarmos a impossibilidade de realização de pesquisas num contexto de clandestinidade e ilicitude.

Duas de nossas mais destacadas pesquisadoras desse tema, no campo da Saúde Pública, as Professoras Maria Cecília de Souza Minayo e Suely Ferreira Deslandes ${ }^{44}$, procuraram determinar algumas propostas que pudessem servir de parâmetros para a formulação de políticas de saúde no campo de intersecção entre violência e drogas:

"Como se pode concluir, é muito complexo o fenômeno da violência e sua articulação com as drogas, exigindo que seja tratado com instrumentos, conhecimentos e ações que ultrapassem a mera representação ou o moralismo simplista.

A atuação dos grupos comunitários em relação ao uso de substâncias e violência sugere que o contexto cultural modera e regula intoxicações $e$ ações violentas. Os segmentos e o contexto influenciam a escolha de substâncias, comportamentos e normas, interpretação da situação e a probabilidade de acontecerem agressões. É preciso tomar o contexto em consideração, sobretudo quando se trata de situações de alto risco. A análise de eventos deve focalizar conseqüências das interações comportamentais, interações entre substância e pessoa, interações entre pessoas e pessoas, além da quantidade de drogas ou álcool consumidos e o tempo de uso.

\footnotetext{
${ }^{44}$ MINAYO, Maria Cecília de Souza; DESLANDES, Suely Ferreira. A complexidade das relações entre drogas, álcool e violência. Cadernos de Saúde Pública, São Paulo, v. 14, n. 1, 1998. Disponível em: $<$ http://www.scielosp.org $>$.
} 
As ações produzidas visando à prevenção precisam ser elaboradas incluindo as comunidades e suas instituições, os diversos setores públicos (Educação, Saúde e Justiça), as empresas e os meios de comunicação de massa (OSAP, 1991). Posturas, habilidades e alternativas de lazer podem ser categorias trabalhadas em ações de prevenção. Tais ações devem ser elaboradas levando-se em conta o contexto a que se destinam e questões fundamentais, como o grupo etário, gênero, características individuais, situação social, tipo de comunidade e participação em grupos específicos. Uma atitude de 'escuta', aberta às vivências dos grupos e apoiada numa perspectiva pedagógica centrada no respeito e atenta às peculiaridades sócioculturais são elementos muito importantes. Sem dúvida, as ações de prevenção ao abuso de drogas só alcançarão real efetividade se houver um investimento significativo e de qualidade na educação básica, na melhoria das condições de vida, na oferta de emprego sobretudo para jovens de comunidades mais pobres, no reforço cultural de valores que desfavoreçam a drogadição abusiva e na valorização do diálogo e apoio familiar".

É curioso que, embora sem indicar como via preferencial, as estratégias de redução de danos como forma de intervenção adequada para as ações políticas de saúde pública na intersecção dos fatores violência e drogas, as renomadas pesquisadoras praticamente terminam por descrever, através do elenco de medidas por elas indicado, o modelo tipicamente definido como ações de redução de danos, especialmente se considerarmos os fundamentos ético materiais apontados como reitores das ações e seus critérios objetivos, formais para a sua elaboração e planejamento. 


\section{A REDUÇÃO DE DANOS}

\subsection{Conceito}

Na ótica da Saúde Pública, pode-se conceituar a política de redução de danos como um conjunto de estratégias que visam minimizar os danos causados pelo uso de diferentes drogas, sem necessariamente exigir a abstinência do seu uso ${ }^{45}$. Vale dizer, enquanto não for possível ou desejada a abstinência, outros agravos à saúde podem ser evitados, como por exemplo, as doenças infecto-contagiosas transmissíveis por via sanguínea, como é o caso do HIVAids e das hepatites.

A nova abordagem leva em consideração múltiplos aspectos, tais como: a complexidade do fenômeno, a diversidade das substâncias e seus usos e as particularidades sociais, culturais e psicológicas dos usuários, possibilitando, do cotejo de toda essa gama de variáveis, uma melhor ponderação e individualização dos riscos e das vulnerabilidades na cena de uso de drogas.

Na concepção da política de redução de danos tem-se como pressuposto o fator histórico-cultural do uso de psicotrópicos e, uma vez cientes de que o uso dessas substâncias é parte indissociável da própria história da humanidade, que a pretensão de um mundo livre de drogas não passa de uma quimera. Dentro dessa perspectiva contempla ações voltadas para as drogas lícitas e ilícitas, e suas intervenções não são de natureza estritamente públicas, delas participando, também, organizações não governamentais e, necessariamente e com especial ênfase, o próprio cidadão que usa drogas.

A redução de danos contrapõe-se, desse modo, ao modelo tradicional, de cunho meramente proibicionista-punitivo, que desconsidera a complexidade do fenômeno, buscando uma meta única: a erradicação da produção e consumo das drogas etiquetadas de

\footnotetext{
${ }^{45}$ BASTOS, Francisco Inácio; MESQUITA, Fábio. Drogas e Aids: estratégias de redução de danos. São Paulo: Hucitec, 1994. p. 181. No mesmo sentido: TRIGUEIROS, Daniela Piconez; HAIEK, Rita de Cássia. Estratégias de redução de danos entre usuários de drogas injetáveis. In: SILVEIRA, Dartiu, Xavier da; MOREIRA, Fernanda Gonçalves. Panorama atual de drogas e dependências. São Paulo: Atheneu, 2006. p. 355. Ver ainda: DOMANICO, Andrea. Craqueiros e cracados: bem vindo ao mundo dos nóias: estudo sobre a implementação de estratégias de redução de danos para usuários de crack nos cinco projetos-piloto do Brasil. 2006. Tese (Doutorado) - Universidade Federal da Bahia, Salvador, 2006. p. 69; REGHELIN, Elisangela Melo. Redução de danos: prevenção ou estímulo ao uso indevido de drogas injetáveis. São Paulo: Ed. Revista dos Tribunais, 2002. p. 76. Aliás essa é, em linhas gerais, a mesma definição adotada pela OMS ( Organização Mundial da Saúde) e pelo Ministério da Saúde do Brasil.
} 
ilícitas. A redução de danos, por seu turno, funda-se nos princípios de pluralidade democrática, exercício da cidadania, respeito aos direitos humanos e de saúde $e^{46}$.

A multiplicação dos programas de redução de danos pelo País e o consequente ${ }^{47}$ aumento de pesquisas nas mais diversas áreas do conhecimento sobre o tema, resultou na elaboração e adoção de novas estratégias visando a atenção a outros públicos e outras drogas o que terminou por proporcionar uma ampliação de seu campo de atuação, diversificando suas aplicações e ganhando novos foros que não mais se restringem à saúde pública.

Diante desse novo contexto, pode-se pretender uma ampliação conceitual definindo-a como uma política humanista e pragmática que visa a melhora do quadro geral do cidadão que usa drogas, sem que lhe seja exigida a abstinência ou imposta a renúncia ao consumo dessas substâncias. A ótica da nova abordagem é a de que se o cidadão usa drogas, ao menos que o faça com os menores danos possíveis à sua saúde, física e mental, à sua vida de relação, família, trabalho, sociedade, etc. e, finalmente, à própria comunidade em que vive.

Um dos pioneiros na implantação das estratégias de redução de danos, o pesquisador australiano, Alex Wodak $^{48}$, destaca que, em muitos países onde as estratégias de redução de danos já se encontram sedimentadas há anos, firmou-se uma estreita cooperação entre as agências de segurança pública e as de saúde pública, no sentido de notificar, por exemplo, os serviços médicos de novas substâncias no mercado ilícito de drogas ou ainda da presença de substâncias psicoativas adulteradas no comércio clandestino. Em contrapartida, a polícia tem constatado uma diminuição dos índices de criminalidade conexos ao uso e comércio clandestinos de substâncias psicoativas, em função da adesão dos cidadãos que usam drogas aos programas de redução de danos.

Mas além do estabelecimento de vínculos com os serviços de atenção, o cidadão usuário de psicotrópicos passa a se reconhecer não mais pela rotulagem sócio-cultural que assumiu como estigma, maconheiro, louco, delinquente, bandido, pária, marginal, para assumir-se como um cidadão sujeito de direitos, protagonista das reivindicações de seu

\footnotetext{
${ }^{46}$ DOMANICO, Andrea. op. cit., p. 70.

${ }^{47}$ A pesquisa e utilização de dados científicos são princípios norteadores das estratégias de redução de danos.

${ }^{48}$ WODAK, Alex. Redução de danos e programas de trocas de seringas. In: BASTOS, Francisco I.; MESQUITA, Fábio; MARQUES, Luiz Fernando. Troca de seringas drogas e aids: ciência, debate e saúde pública. Brasília: Ministério da Saúde, 1998. p. 56.
} 
contexto social e responsável pela implementação das modificações necessárias para a melhoria de sua vida pessoal e relacional.

Os resultados exitosos das estratégias de saúde pública que ultrapassam as fronteiras epistemológicas de seu campo de atuação, permitem reivindicar a ampliação do âmbito de ação dessa política pública para outras áreas próprias da intervenção estatal, sendo a política criminal de especial interesse para o presente trabalho.

\subsection{Evolução histórica}

\subsubsection{No Mundo}

Na história das drogas, pode-se colher inúmeros relatos indicativos de que sempre houve uma preocupação com a administração segura dessas substâncias. A própria ritualização do uso dessas substâncias, utilizadas dentro de uma liturgia própria dos cultos religiosos, funcionava como mecanismo de controle informal. A clássica tragédia grega de Eurípedes, As Bacantes, concebida aproximadamente há 2400 anos, nos dá a dimensão desse fenômeno. Trata-se da narrativa sobre o culto a Dionísio, deus do vinho e da vindima, e a reação punitiva do Estado e suas consequiências, às celebrações em seu louvor, que acabaram por ser conhecidas como bacanais ${ }^{49}$. Essa preocupação indica o reconhecimento de possíveis malefícios com a ingestão de psicotrópicos e já nos dá uma noção, ainda que preliminar, da redução de danos à saúde associados ao uso de drogas.

Todavia, a quase totalidade dos autores, estabelece como marco histórico da nova concepção de redução de danos, o chamado Relatório Rolleston, publicado em 1926, na Inglaterra. O nome decorre do trabalho de Sir Humphrey Rolleston, ex-presidente do

\footnotetext{
${ }^{49}$ A célebre tragédia de Eurípedes pode ser dividida em três atos bastante simbólicos: um primeiro de rejeição ao fenômeno - quando a população de Tebas guiada por seu rei, Penteo, nega-se a acreditar no mito segue-se daí o imediato crescimento do culto ao vinho e à luxúria com a esperada reação do Estado, representado por Penteo, determinando a punição e mesmo a prisão de Dionísio. As medidas punitivas colocam a todos na clandestinidade, o que apenas aumenta seu apelo e difusão. A situação apenas se estabilizará quando a própria comunidade passa a crer na existência de Dionísio e estabelece épocas próprias para as celebrações e liturgias em seu louvor; rituais que, na verdade, servirão como mecanismos de controle na administração das substâncias consumidas nessas ocasiões. In: ESCOHOTADO, Antonio. Historia general de las drogas, cit., p. 151-158.
} 
Colégio Real de Médicos do Reino Unido, cujo pioneirismo na área mereceu o reconhecimento emprestando seu nome ao documento elaborado pela equipe.

Esse relatório foi produzido por solicitação do governo inglês e a política dele decorrente era basicamente pautada nas necessidades dos usuários de drogas e na "normalização" de sua vida cotidiana. Essa normalização implicava em diversas iniciativas como promover a administração da droga e seu monitoramento, por um médico, a esses indivíduos. ${ }^{50}$

Todavia, a nova abordagem da saúde pública realmente ganha expressão a partir dos programas de troca de seringas usadas por novas, que acabaram por se notabilizar como uma das principais estratégias de redução de danos implementadas globalmente, que surgiram somente em 1986, após ter sido comprovado o sucesso de programa análogo em Amsterdã $^{51}$.

Que a intervenção pioneira tenha surgido na Holanda e mais especificamente na cidade de Amsterdã não deve causar estranheza. Embora seja signatária dos tratados internacionais sobre a matéria, a Holanda sempre se destacou no concerto internacional por patrocinar uma política mais liberal.

Já no ano de 1976, o governo holandês, preocupado com os riscos relacionados ao uso de psicotrópicos, sancionou uma lei que estabelecia tratamento diferenciado às distintas drogas e de acordo com a potencialidade de dano de cada uma delas. Assim foram diferenciadas as de risco aceitável ou "drogas leves" (maconha e haxixe) das drogas de risco inaceitável ou "drogas pesadas” (cocaína, heroína, anfetaminas e LSD).

A partir dessa distinção, as políticas públicas implementadas buscam auxiliar os usuários de drogas a melhorar seu estado físico e social, contando com sua participação direta, fator, aliás, essencial para a boa execução dos programas ${ }^{52}$.

Nesse contexto de protagonismo das pessoas que usam drogas é que, em 1980, em Amsterdã, foi fundada a "Junkiebond" - a primeira associação de usuários de drogas

\footnotetext{
${ }^{50}$ ANDRADE, Tarcísio Matos de; FRIEDMAN, Samuel R. Princípios e práticas de redução de danos: interfaces e extensão a outros campos da intervenção e do saber. In: SILVEIRA, Dartiu, Xavier da; MOREIRA, Fernanda Gonçalves. Panorama atual de drogas e dependências. São Paulo: Atheneu, 2006. p. 395. No mesmo sentido: BASTOS, Francisco Inácio; MESQUITA, Fábio. op. cit., p. 181. Ver ainda: REGHELIN, Elisangela Melo. op. cit., p. 80.

${ }^{51}$ BUNING, Ernst. Vinte e cinco anos de redução de danos: a experiência de Amsterdã. In: SILVEIRA, Dartiu, Xavier da; MOREIRA, Fernanda Gonçalves. Panorama atual de drogas e dependências. São Paulo: Atheneu, 2006. p. 345.

${ }^{52}$ RODRIGUES, Luciana Boiteux de Figueiredo. op. cit., p. 122.
} 
injetáveis - constando dentre seus objetivos a busca da melhoria da qualidade de vida dos usuários de drogas. Em 1984, a "Junkiebond", preocupada com a crescente difusão da Hepatite B entre os usuários de drogas injetáveis iniciou, com o apoio do governo, um projeto piloto de troca de agulhas e seringas usadas por novas $\left(\mathrm{PTS}^{53}\right.$ ). Assim, o surgimento da ação de saúde foi inicialmente concebida com a preocupação de prevenir hepatites e somente quando se passa a ter certeza da transmissão do vírus $H I V$ pela via sanguínea, a prevenção a AIDS passa a ser uma meta a mais desses programas ${ }^{54}$.

Constatado o êxito da experiência holandesa na contenção da contaminação de doenças infecto-contagiosas pela via endovenosa através dessa ação de saúde pública, as estratégias começaram a ser sistematizadas e passaram a ser adotadas em vários países do mundo. Já no ano de 1985, a Austrália iniciou um programa de âmbito nacional com projetos de troca de seringas como forma de prevenção à epidemia de HIVIAids; o Canadá implantou seus primeiros programas em 1887; nos Estados Unidos, embora de forma precária e sem apoio governamental, iniciaram-se alguns programas no final da década de 80. Na Europa, países como a França, Alemanha e Suíça também iniciaram projetos de redução de danos na mesma época ${ }^{55}$.

Com o desenvolvimento desses projetos, o conceito de Redução de Danos foi sendo revisto, ampliado e incorporado por muitos atores da saúde pública, governamentais ou não, preocupados com a prevenção de doenças infecto-contagiosas e outros agravos associados ao uso de drogas.

Na União Europeia, na atualidade, verifica-se uma clara tendência dos estadosmembros de se adequarem às recomendações de seus órgãos gestores no sentido de adotarem legislação específica sobre as estratégias de redução de danos, como forma de legitimação e regulamentação dessas políticas em seus diversos aspectos.

O relatório do Observatório Europeu de Drogas e Toxicodependências, relativo ao ano de 2005, nos dá conta de que sete estados-membros legislaram sobre o tema desde 1999: Bélgica, França, Luxemburgo, Polônia, Portugal, Eslovênia e Finlândia.

\footnotetext{
${ }^{53}$ Abreviação adotada pela Saúde Pública: projeto de troca de seringas.

${ }^{54}$ VESTER, Annette. Os programas de troca de seringas em Amsterdã. In: BASTOS, Francisco I.; MESQUITA, Fábio; MARQUES, Luiz F. Troca de seringas: ciência, debate e saúde pública. Brasília: Ministério da Saúde, 1998. p. 115. Ver ainda: BUNING, Ernst. op. cit., p. 346-347.

${ }^{55}$ DOMANICO, Andrea. op. cit., p. 68.
} 


\subsubsection{No Brasil}

Com o recrudescimento da militarização das políticas de drogas, patrocinada pelos Estados Unidos da América, nos países andinos produtores de coca a partir dos anos 70, os cartéis produtores buscaram a viabilização de rotas alternativas para o escoamento de sua produção em direção aos grandes mercados consumidores, notadamente Estados Unidos e Europa.

Essa estratégia terminou por conferir ao Brasil uma situação privilegiada, na visão das máfias controladoras do mercado clandestino, devido à sua extensa e desguarnecida fronteira com os países produtores, a navegabilidade dos rios amazônicos além de sua malha viária que cobre toda a extensão territorial e seu sistema bancário, fatores que terminaram por inserir o país, definitivamente, na rota internacional do tráfico de cocaína. Evidentemente que, em conseqüência, passamos a ter uma maior quantidade de drogas circulando pelo Brasil ${ }^{56}$.

Relativamente ao uso de drogas injetáveis, é interessante destacar que, até a década de 70, seus adeptos tinham como droga de eleição a anfetamina que era livremente adquirida na rede farmacêutica. Somente após sua proibição é que começam a usar cocaína injetável, mudança explicável tanto pelo fato de ser a cocaína um estimulante, com efeitos análogos aos da anfetamina, quanto pelo aumento da disponibilidade do produto em razão de sua maior presença no mercado ilícito ${ }^{57}$.

A partir da epidemia de Aids, inúmeros pesquisadores ${ }^{58}$ detectam o crescimento do número de casos entre os usuários de drogas injetáveis, nas cidades que passaram a integrar as rotas de tráfico de cocaína.

A cidade de Santos ganhou posição de destaque nesse novo contexto, em função de sua localização estratégica e infraestrutura logística, e passou a ser uma das principais opções de rota de escoamento da droga para os mercados externos. Esse fato terminou por causar um grande impacto na saúde pública municipal e é certo que, de 1988 em diante, a cidade liderou durante anos o ranking de números de casos de Aids proporcionais à

\footnotetext{
${ }^{56}$ MESQUITA, Fábio et. al. Aids ente usuários de drogas injetáveis na região metropolitana de Santos, na década de 1990. In: A CONTRIBUIÇÃO dos Estudos Multicêntricos frente à epidemia de HIV/Aids entre UDI no Brasil: 10 anos de pesquisa e redução de danos. Brasília: Ministério da Saúde, 2001. p. 14.

${ }^{57}$ DOMANICO, Andrea. op. cit., p. 70.

${ }^{58}$ BASTOS, Francisco Inácio; MESQUITA, Fábio. op. cit.
} 
população do país. Em meados da década de 90, metade das notificações de casos de Aids no município tinha como vetor epidemiológico o uso de drogas injetáveis ${ }^{59}$.

Diante desse quadro foi criado em Santos, em 1989, o primeiro programa de redução de danos associados ao uso de drogas injetáveis do Brasil ${ }^{60}$. O programa adotava, como estratégia, a troca de seringas novas pelas usadas. Todavia, a divulgação precipitada da ação, pelos principais veículos de comunicação do país, gerou intensa polêmica e provocou a intervenção das instâncias formais, notadamente a Polícia e o Ministério Público.

As agências penais viram nas ações de saúde pública condutas típicas penalmente, uma vez que se subsumiam ao disposto no artigo $12, \S 2^{\circ}$, incisos I e III da Lei de Entorpecentes então vigente, vale recordar, a Lei 6.368, de 21 de outubro de 1976. Tais dispositivos legais equiparavam as condutas de induzir, instigar, auxiliar alguém a usar ou contribuir de qualquer forma para incentivar ou difundir o uso de substâncias psicoativas àquelas relativas ao tráfico ilícito, impondo, a umas e outras, penas que poderiam variar de três a quinze anos de reclusão ${ }^{61}$.

Em função dessa interpretação canhestra foi instaurado inquérito policial contra os coordenadores do projeto e o Secretário da Saúde do Município, além da propositura de ação civil pública contra a Prefeitura Municipal e as entidades envolvidas com o desenvolvimento do programa que, face à assinatura de um Termo de Ajustamento de Conduta pela municipalidade, foi interrompido e, embora o inquérito policial tenha sido arquivado, sua implantação permanece obstaculizada até os dias de hoje, apesar de seu pioneirismo no país.

Inicia-se, a partir daí, um processo de debates e encontros públicos buscando esclarecer e sensibilizar a opinião pública e obter a compreensão dos agentes públicos para com as ações de redução de danos. Nessa nova empreitada e já em 1991, foi criado o IEPAS - Instituto de Estudos e Pesquisas em AIDS de Santos, organização nãogovernamental composta por diversos profissionais de saúde ligados àquele primeiro programa. Com base em pesquisas de campo junto aos usuários, a equipe do Instituto

\footnotetext{
${ }^{59}$ MESQUITA, Fábio et. al. op. cit., p. 15.

${ }^{60}$ BUENO, Regina. Estratégias de redução de danos em Santos. In: BASTOS, Francisco I.; MESQUITA, Fábio; MARQUES, Luiz Fernando. Troca de seringas drogas e aids: ciência, debate e saúde pública. Brasília: Ministério da Saúde; 1998. p. 163.

${ }^{61}$ A nova Lei de Drogas, $n^{\circ} 11.343 / 06$, equacionou melhor a questão fazendo previsão específica das modalidades de participação, no $\S 2^{\circ}$ do artigo 33, cominando-lhes penas de detenção de 1 (um) a 3 (três) anos e multa de 100 (cem) a trezentos (trezentos) dias-multa.
} 
iniciou uma nova intervenção, em razão da impossibilidade de retomada do projeto original, valendo-se de experiência exitosa que vinha sendo aplicada no exterior - a distribuição de hipoclorito de sódio para desinfecção das seringas.

Em campo, os agentes de saúde constataram que os usuários de drogas injetáveis lavavam as seringas antes da sua reutilização, para remover possíveis vestígios de sangue que pudessem coagular e entupir a agulha durante o compartilhamento do equipamento. Frente a isso, começaram a distribuir o hipoclorito de sódio - com uma concentração de 5,25\% - para que os usuários o utilizassem na lavagem de suas seringas, sendo que já era cientificamente demonstrado que essa era a concentração suficiente para eliminar o vírus do $H I V^{62}$.

Nesse mesmo ano, a Coordenação Nacional de DST/Aids do Ministério da Saúde cria um setor específico para estas demandas, o "Projeto de Drogas" visando o fomento e a elaboração de novos projetos. De início, o "Projeto" contemplou dez Estados (Rio Grande do Sul, Santa Catarina, Paraná, São Paulo, Rio de Janeiro, Mato Grosso, Mato Grosso do Sul, Distrito Federal, Ceará e Bahia) como prioritários por apresentarem um quadro epidemiológico com alta taxa de notificação de casos de Aids contraídos pelo compartilhamento de seringas durante o uso de drogas injetáveis. A prioridade, na época, foi dada aos usuários de drogas injetáveis devido à eficiência dessa via de uso na transmissão sanguínea do vírus $H I V$.

Seguindo a mesma tendência, o Programa Estadual de DST/Aids do Estado de São Paulo criou um projeto de redução de danos para usuários de drogas injetáveis, com previsão de adoção da estratégia de troca de seringas utilizadas por novas, mas, também por questionamentos judiciais, não conseguiu implantá-lo, naquela oportunidade.

Foi necessário o decurso de seis anos, a partir da iniciativa pioneira de Santos, de intensos debates e embates, para que, em março de 1995, o primeiro programa de troca de seringas, sediado no CETAD - Centro de Estudos e Terapia do Abuso de Drogas, na cidade de Salvador, pudesse efetivamente ser operacionalizado. Dado relevante que certamente contribuiu para a aceitação desse projeto foi a circunstância de ele estar alocado num centro de estudos da Faculdade de Medicina da Universidade Federal da Bahia. A

\footnotetext{
${ }^{62}$ DOMANICO, Andrea. op. cit. A autora alerta para o fato de que embora eficiente contra o vírus HIV, o procedimento não é eficaz como prevenção às hepatites virais.
} 
partir de então, esse modelo institucional passou a ser o mais comumente adotado para a implantação dos programas de redução de danos.

A necessidade de se implementar as estratégias de saúde pública que atingissem o público-alvo dos usuários de drogas injetáveis foi demonstrada através de evidências científicas quando, nos anos de 1994 e 1996, o Ministério da Saúde patrocinou o maior estudo epidemiológico sobre prevalência de $H I V$ e comportamento entre usuários de drogas injetáveis no país e que apontou uma tendência de crescimento da epidemia nesse universo específico.

Como consequência do avanço dos projetos e pesquisas foram surgindo novos atores sociais comprometidos com as ações de redução de danos. Esse fato determinou um incremento na criação de Organizações Não Governamentais com o objetivo de pesquisar e/ou implementar projetos com estratégias para reduzir os danos à saúde entre usuários de drogas.

Dentro desse processo, merece destaque a fundação, em 1997, da primeira associação de caráter nacional que é declaradamente integrada por usuários ou ex-usuários de drogas, agora vistos e reconhecidos como sujeitos de direito, a Associação Nacional de Redutores de Danos ${ }^{63}$, ABORDA, que tem por objetivo "lutar pelos direitos dos redutores de danos e usuários de drogas".

O ano seguinte, 1998, foi especialmente representativo para o desenvolvimento das estratégias de redução de danos no Brasil, pois, além de o país sediar a IX Conferência Internacional de Redução de $\operatorname{Danos}^{64}$, que foi realizada em março, na cidade de São Paulo, durante a cerimônia de abertura do evento, na sede do governo estadual, foi anunciada a sanção pelo Governador do Estado de São Paulo, da Lei Estadual n ${ }^{\circ}$ 9.758/97, a primeira lei no Brasil que regulamentou essa matéria e que autorizou as ações de troca de seringas no Estado.

O advento da lei paulista foi o marco inicial de uma nova etapa na história da redução de danos no Brasil, uma vez que as estratégias de redução de danos foram, a partir

\footnotetext{
${ }^{63} \mathrm{~A}$ maioria dos agentes de saúde comunitários que trabalham com redução de danos é composta de usuários ou ex-usuários de drogas. Isso possibilita uma melhor interlocução entre os agentes e usuários na cena de uso e reduz a atitude refratária desse universo para com agentes do poder público, criando um vínculo com os serviços sociais de atenção à saúde até então desconhecido pelas outras modalidades de intervenção. Nesse contexto que surgiu a categoria de redutor de danos, como forma de dar legitimidade aos agentes de saúde comunitários que participavam e desenvolviam o trabalho de campo.

${ }^{64} \mathrm{~A}$ conferência recebeu 800 delegados de 50 países diferentes. Foi palco de rico debate de alto nível científico, focando a redução de danos em diferentes contextos sócio-culturais.
} 
de então, legitimadas e assumidas como política pública. A repercussão dessa medida é sentida de imediato, com a multiplicação de novas leis, estaduais e municipais, autorizando e regulamentando as estratégias de redução de danos.

Encerrando o ano de 1998, a REDUC - Rede Brasileira de Redução de Danos, uma nova organização de caráter nacional, é fundada e os programas a partir de então se multiplicam, agora com definitivo apoio oficial.

Surge daí a necessidade de uma legitimação uniformizada das estratégias de redução de danos, o que leva o Ministério da Saúde a editar a portaria $\mathrm{n}^{\circ} 1.059$, de 4 de julho de $2005^{65}$, que regulamentou as ações de redução de danos em Centros de Atenção Psicossocial para o Álcool e outras Drogas - CAPSad. Essa normativa define as políticas de atenção em saúde voltadas às pessoas que usam drogas, em conformidade com os princípios e diretrizes do SUS, indicando as ações de saúde como direito desses cidadãos.

Mas não é só. Dizer que a saúde é um direito das pessoas que usam drogas implica em romper com o caráter normativo da atenção em saúde, devolvendo às pessoas que eventualmente venham a se valer desses serviços o direito de decidir sobre os modelos de atenção de sua preferência. Além disto, a redução de danos aparece devidamente caracterizada como forma de atenção em saúde.

Também nesse mesmo sentido e não menos importante, foi o posicionamento oficial da Secretaria Nacional Antidrogas, a SENAD, encampando a redução de danos como uma das estratégias da Política Nacional Antidrogas brasileira, nos termos da resolução n³/ CONAD, de 27 de outubro de 2005 ${ }^{66}$. Ao enunciar os pressupostos ideológicos da nova Política Nacional, a resolução deixa expressamente assentado que tem como meta "Não confundir as estratégias de redução de danos com o incentivo ao uso indevido de drogas, pois se trata de uma estratégia de prevenção".

Além disso, a Política Nacional, estabelecida pela citada portaria, reservou para a redução de danos um capítulo próprio, no qual estabeleceu inúmeras diretrizes e reconheceu a necessidade de fortalecer a implementação das estratégias de redução de danos em todos os níveis do sistema federativo, e enunciou como orientação geral para o Sistema Nacional a indicação de que "a promoção de estratégias e ações de redução de danos, voltadas para a saúde pública e direitos humanos, deve ser realizada de forma

\footnotetext{
${ }^{65}$ Vide anexo 1.
}

${ }^{66}$ Vide anexo 2. 
articulada inter e intra-setorial, visando a redução dos riscos, as consequiências adversas e os danos associados ao uso de álcool e outras drogas para a pessoa, a família e a sociedade".

Esse novo avanço das ações práticas e do debate social e político acabou por refletir na produção legislativa, propriamente dita, fazendo surgir a segunda geração de leis de redução de danos, que agora se preocupa com os direitos do próprio cidadão que usa drogas, como é o caso da Lei Estadual Paulista de $n^{\circ}$ 12.258, de 9 de fevereiro de 2006, que dispõe sobre a prevenção, o tratamento e os direitos fundamentais dos usuários de drogas.

Nesse passo há uma evidente mudança de paradigmas pois a pessoa que usa drogas passa a ser vista como sujeito de direitos, tendo assegurada, a garantia de não exclusão de escolas, centros esportivos e outros próprios do estado; a garantia de não sofrer discriminação em campanhas contra o uso de drogas que diferenciem os usuários dos dependentes; o acesso a tratamentos que respeitem sua dignidade, permitindo sua reinserção social; o direito de ser informado, de todas as formas, estratégias, tipos e etapas de tratamentos, incluindo os desconfortos, riscos, efeitos colaterais e benefícios do tratamento; o apoio psicológico durante e após o tratamento, dentre outros direitos e garantias típicas do exercício da cidadania, num Estado Social Democrático de Direito.

Todo esse conjunto de mudanças sócio-político-culturais abriu espaço para que novas possibilidades de intervenção fossem agregadas às estratégias iniciais que eram voltadas quase que unicamente para os usuários de drogas injetáveis. Iniciam-se, então, ações voltadas aos usuários de cocaína inalada, com fornecimento de kits próprios para essa modalidade de uso ${ }^{67}$; com pesquisas sobre uso terapêutico da cannabis e possíveis terapias de substituição (cocaína/cannabis, crack/cannabis); redução de danos e crack, com fornecimento de cachimbos próprios, filtros e pesquisas sobre eventuais terapias de substituição; redução de danos e drogas sintéticas, especialmente o ecstasy, com intervenções junto ao público frequentador das casas noturnas, fornecendo-lhes orientações sobre esses psicotrópicos e formas de consumo; além de estratégias adequadas às drogas lícitas: bebidas alcoólicas, tabaco e fármacos lícitos, como moderadores de apetite; bem como intervenções para as chamadas dependências não químicas: jogo patológico, transtornos alimentares, descontrole sexual, etc.

\footnotetext{
${ }^{67} \mathrm{O}$ kit é composto, basicamente, de um cartão de plástico, dois canudos de silicone, material informativo sobre hepatites virais, Aids, doenças sexualmente transmissíveis e direitos humanos, material para assepsia.
} 
Há propostas de ações para populações específicas, como a população carcerária, sendo certo que já existem projetos pilotos nos Estados de São Paulo e Paraná. Discute-se, ainda, a viabilidade de implantação de locais especialmente destinados para o uso seguro, como já ocorre em alguns países europeus, como Alemanha, Espanha e Portugal, bem como no Canadá e na Austrália.

Embora não se possa dizer que as estratégias de redução de danos já façam parte da vida cotidiana dos cidadãos brasileiros ${ }^{68}$, é possível encontrar disponíveis em locais públicos - especialmente banheiros de rodoviárias e aeroportos - repositórios próprios para a dispensa segura de agulhas e seringas utilizadas e máquinas de auto-atendimento para a aquisição de preservativos a preços subsidiados.

Também foi aprovada lei que obriga as casas noturnas do Estado de São Paulo a disponibilizarem bebedouros de água potável com a finalidade de controlar e/ou evitar a hipertermia, um dos principais efeitos colaterais gravosos à saúde, decorrente do uso das novas drogas sintéticas (MDMA ou ecstasy e análogos), substâncias comuns nos clubes noturnos e nas chamadas raves $^{69}$, não se podendo esquecer, ainda, que a hidratação é um importante fator na normalização dos casos de abuso de álcool. ${ }^{70}$

Atualmente estão oficialmente registradas na Receita Federal duas associações nacionais de redução/redutores de danos e mais de 25 associações estaduais. Hoje são 267

\footnotetext{
${ }^{68}$ Veja-se, por exemplo, a reação moralista dos órgãos de imprensa frente à divulgação do conteúdo de folheto informativo que era distribuído durante a realização da chamada "Parada do Orgulho Gay", num projeto de informações sobre uso de drogas a públicos específicos que vinha sendo patrocinado tanto pelo Ministério da Saúde quanto pela Secretaria Estadual da Saúde. A reação à divulgação parcial e equivocada do programa desenvolvido teve reflexos em outros setores, inclusive a pesquisa científica levando a FAPESP - Fundação de Amparo à Pesquisa do Estado de São Paulo a suspender o financiamento do projeto "Implantação e Avaliação de Programa de Redução de Danos para o Uso de Ecstasy na cidade de São Paulo", coordenado pela pós-doutoranda em psicologia, a Dra. Stella Pereira de Almeida, e sua orientadora a Professora Titular do Instituto de Psicologia da Universidade de São Paulo, a Prof. Dra. Maria Teresa Araújo Silva, conforme noticiado em todos os jornais da época (vide Folha de São Paulo do dia 05.07.2007 - reportagem da jornalista Laura Capriglione). É importante ressaltar, todavia, a pronta e articulada reação de diversos setores da sociedade civil, especialmente os setores acadêmicos e as organizações não-governamentais ligadas às questões de aids, sexualidade, drogas, redução de danos e direitos humanos, fato que levou a agência de fomento à pesquisa paulista a reconsiderar sua decisão e retomar a pesquisa. Todavia, ao término do cronograma, não renovou o financiamento do programa e, além disso, as ilustres professoras e pesquisadoras continuaram respondendo a procedimento investigatório instaurado pelo Ministério Público junto ao Grupo de Atuação Especial de Saúde Pública e da Saúde do Consumidor - GAESP, bem como a inquérito policial requisitado pelo mesmo órgão do Ministério Público, procedimentos que só foram interrompidos com a impetração de um Habeas Corpus visando o trancamento do inquérito, que foi deferido e que implicou no arquivamento do procedimento civil.

${ }^{69}$ Festas que podem durar dias, em geral realizadas em ambientes amplos e inusitados ou ao ar livre, embaladas por música eletrônica. Segundo Houaiss (op. cit., p. 2389): "reunião dançante de jovens aficionados de rock, rap etc., geralmente de caráter semiclandestino e não isento de espírito rebelde, que se instala em grandes espaços, não contando com sede fixa."

${ }^{70}$ Lei estadual $\mathrm{n}^{\mathrm{o}} 12.637$ de 06 de julho de 2007.
} 
projetos de redução de danos ativos no Brasil, que acessam aproximadamente 146 mil usuários de drogas injetáveis, o que corresponde a $18 \%$ desse universo segundo estimativas do Programa Nacional de DST/Aids ${ }^{71}$. De qualquer sorte, embora esse número esteja subdimensionado em razão de não computar programas que são implementados sem a supervisão direta do Programa Nacional, pode-se ter uma noção do potencial de crescimento dos projetos uma vez que, conforme anotado, o número de pessoas acessadas pelos programas é estimado em menos de $20 \%$ dos cidadãos destinatários dessas políticas.

\subsection{O modelo de Redução de Danos}

\subsubsection{O arcabouço principiológico: Direitos Humanos - dignidade da pessoa humana}

Como já podemos apreender da própria evolução histórica das estratégias de redução de danos, suas abordagens às pessoas que usam drogas têm como fio condutor o respeito à dignidade da pessoa humana. A redução de danos vê no usuário não um sujeito objeto de sua tutela ou repressão, mas um interlocutor qualificado, um sujeito de direitos que deve, como tal, participar assumindo um papel de protagonista das reivindicações de seu contexto social e corresponsável pela implementação das modificações necessárias para a melhoria de sua qualidade vida, pessoal e relacional.

Essa postura ética não poderia ser outra, basta lembrarmos que a abordagem sempre teve em consideração a qualidade de vida do usuário e, na fase de expansão da estratégia seus pioneiros foram os próprios usuários holandeses, constituídos em associação, a Junkiebond e, posteriormente, com o advento da epidemia de HIVIAids, ela é incorporada às redes de atenção que já eram formadas por pessoas militantes de diversos segmentos vulneráveis à doença. Dessa forma, o protagonismo das pessoas que usam drogas e o respeito devido na atenção a eles dirigida já fazia parte dos princípios fundantes da redução de danos.

\footnotetext{
${ }^{71}$ DONEDA, Denise; GANDOLFI, Denise. O início da redução de danos no Brasil na perspectiva governamental: ação local com impacto nacional. In: SILVEIRA, Dartiu, Xavier da; MOREIRA, Fernanda Gonçalves. Panorama atual de drogas e dependências. São Paulo: Atheneu, 2006. p. 359.
} 
Temos, portanto, que a política de redução de danos se baseia no respeito à dignidade do usuário, na sua autonomia e liberdade individual e tem por meta a moderação, ao contrário do proibicionismo-punitivo, que estabelece o máximo controle penal sobre a venda e consumo de psicotrópicos rotulados como ilícitos, preferencialmente mediante o uso da privação de liberdade, como meio de coerção, perseguindo um ideal de abstinência.

Diva Reali ${ }^{72}$, uma das pioneiras na pesquisa do binômio drogas-redução de danos na área da saúde pública, elaborou uma interessante tabela comparativa entre o modelo proibicionista e as estratégias de redução de danos:

\begin{tabular}{|c|c|c|}
\hline $\begin{array}{l}\text { MODELOS } \\
\text { Problema enfocado }\end{array}$ & $\begin{array}{l}\text { PROIBICIONISTA } \\
\text { o uso de droga em si }\end{array}$ & $\begin{array}{l}\text { REDUÇÃO DE DANOS } \\
\text { Danos/ usos de drogas }\end{array}$ \\
\hline Política de drogas & "guerra às drogas" & Tolerante/ pragmática \\
\hline Prioridade & $\begin{array}{l}\text { Repressão ao uso de drogas ilícitas } \\
\text { e tráfico }\end{array}$ & $\begin{array}{l}\text { Redução de danos à saúde } \\
\text { individual e coletiva }\end{array}$ \\
\hline Postura em relação droga & Moralismo: estigmatização UD: & Realística/ pragmática* \\
\hline Papel/posição do Estado & Controle abusivo do cidadão & $\begin{array}{l}\text { - Provê serviços p/ UDs } \\
\text { - Apóia organizações UD } \\
\text { - Prega direitos dos Uds }\end{array}$ \\
\hline Prevenção de drogas & "sociedade livre de drogas" & Dano/risco assoc. abuso \\
\hline $\begin{array}{l}\text { Sistema atenção à saúde } \\
\text { Serviços }\end{array}$ & $\begin{array}{l}\text { Atendimento médico individual } \\
\text { "alta exigência" } \\
\text { Objetivo: abstinência }\end{array}$ & $\begin{array}{l}\text { vários tipos de serviços } \\
\text { "baixa exigência" ** } \\
\text { "busca ativa" \# }\end{array}$ \\
\hline Prevenção AIDS entre & dificultada por restrições legais & articulada como prioridade \\
\hline Uds/UDIs & & de saúde pública \\
\hline
\end{tabular}

E esses princípios éticos encontram ressonância em nosso ordenamento jurídico, a começar de sua base, a Constituição de 1988, que encampou e alargou significativamente o campo dos direitos e garantias fundamentais. Como atenta Flávia Piovesan ${ }^{73}$, "dentre os fundamentos que alicerçam o Estado Democrático de Direito brasileiro, destacam-se a

\footnotetext{
${ }^{72}$ REALI, Diva. Drogas, redução de danos e direitos humanos: transitando com Winnicott. Revista Urutágua - revista acadêmica multidisciplinar, maringá, n. 6, p. 2-3, 2004.

${ }^{73}$ PIOVESAN, Flávia. Direitos humanos e o direito constitucional internacional. 5. ed. São Paulo: Max Limonad, 2002. p. 58.
} 
cidadania e dignidade da pessoa humana (art. $1^{\circ}$, incisos II e III). Vê-se aqui o encontro do princípio do Estado Democrático de Direito e dos direitos fundamentais, fazendo-se claro que os direitos fundamentais são um elemento básico para a realização do princípio democrático, tendo em vista que exercem uma função democratizadora. Como afirma Jorge Miranda: 'A Constituição confere uma unidade de sentido, de valor e de concordância prática ao sistema dos direitos fundamentais. E ela repousa na dignidade da pessoa humana, ou seja, na concepção que faz a pessoa fundamento e fim da sociedade e do Estado"”.

Mas não só, a Política Nacional sobre Drogas também consagra expressamente a adoção de medidas de redução de danos sob esse fundamento ético, tanto que em seu item 3 dispõe, com relação à redução de danos sociais e à saúde, ser orientação geral (3.1): “A promoção de estratégias e ações de redução de danos, voltadas para a saúde pública e direitos humanos, deve ser realizada de forma articulada inter e intra-setorial, visando à redução dos riscos, das conseqüências adversas e dos danos associados ao uso de álcool e outras drogas para a pessoa”. Mais adiante, ao estabelecer suas diretrizes (3.2) arremata: “ 3.2.1 Reconhecer a estratégia de redução de danos, amparada pelo artigo 196 da Constituição Federal, como medida de intervenção preventiva, assistencial, de promoção da saúde e dos direito humanos. 3.2.3 Diminuir o impacto dos problemas socioeconômicos, culturais e dos agravos à saúde associados ao uso de álcool e outras drogas. 3.2.4 Orientar e estabelecer, com embasamento científico, intervenções e ações de redução de danos, considerando a qualidade de vida, o bem estar individual e comunitário, as características locais, o contexto de vulnerabilidade e o risco social."

E completando um exame sistemático em nossa legislação, tendo como objetivo a afirmação do amparo legal acerca da adoção da proteção da dignidade da pessoa humana, e portanto dos direitos fundamentais, como fundamento ético da estratégias de redução de danos vale analisar os preceitos contidos na própria Lei de Drogas, a Lei n ${ }^{\circ} 11.323 / 2006$.

Conforme já afirmado anteriormente, a nova Lei de Drogas, embora permanecendo alinhada à política proibicionista mundial, procurou conformar-se à nova ordem constitucional adotando seus princípios fundamentais. Esse novo norte principiológico não deve ser considerado apenas como uma petição de princípios. Deve, isto sim, servir de balizamento ao operador do direito como parâmetro a ser adotado para a solução de eventuais conflitos. 
Como é sabido, a nova lei tem como uma de suas finalidades instituir o Sistema Nacional de Políticas sobre Drogas - Sisnad, e para tanto, no seu art. $4^{\circ}$ estabelece os princípios reitores que deverão orientar esse sistema. Inaugurando o rol, no inciso I consta "o respeito aos direitos fundamentais da pessoa humana, especialmente quanto à sua autonomia e à sua liberdade". E segue adiante: "II - o respeito à diversidade e às especificidades populacionais existentes; III - a promoção dos valores éticos, culturais e de cidadania do povo brasileiro, reconhecendo-os como fatores de proteção para o uso indevido de drogas e outros comportamentos correlacionados. Portanto, fica extreme de dúvidas que todo o Sistema Nacional deve pautar suas ações atendendo aos direitos fundamentais da pessoa humana.

Mas não é só, quando trata das atividades de prevenção, no Capítulo I de seu Título III, a Lei de Drogas também estabelece, no art. 19, princípios e diretrizes, dentre eles: “III - o fortalecimento da autonomia e da responsabilidade individual em relação ao uso indevido de drogas; IV - o compartilhamento de responsabilidades e a colaboração mútua com as instituições do setor privado e com os diversos segmentos sociais, incluindo usuários e dependentes de drogas e respectivos familiares, por meio do estabelecimento de parcerias"; orientações que, como se vê, invocam a própria metodologia da redução de danos uma vez que, para ela, os usuários de drogas são corresponsáveis pela produção de saúde à medida que tomam para si a tarefa de cuidado.

Mais adiante, no Capítulo II, ao tratar das atividades de atenção e de reinserção social, a legislação, em seu artigo 22 , volta a reafirmar os princípios e diretrizes: “ I respeito ao usuário e ao dependente de drogas, independentemente de quaisquer condições, observados os direitos fundamentais da pessoa humana, os princípios e diretrizes do Sistema Único de Saúde e da Política Nacional de Assistência Social; II - a adoção de estratégias diferenciadas de atenção e reinserção social do usuário e do dependente de drogas e respectivos familiares que considerem as suas peculiaridades socioculturais", tudo a deixar patente que o respeito aos direitos fundamentais, especialmente à dignidade da pessoa humana, é pauta obrigatória para todas as atividades realizadas por todo o Sistema Nacional de Políticas sobre Drogas.

Como visto, não basta o atendimento de um critério ou requisito formal para que se possa ter a intervenção da política pública como uma estratégia de redução de danos. Assim fosse, poderíamos incluir sob a mesma rubrica ações como tratamento e internações compulsórias, independentemente das peculiaridades ou mesmo da necessidade da pessoa 
que se utiliza dessas substâncias ou mesmo a internação coletiva, posto que, numa interpretação literal, pode ser alegado que há uma redução de danos nesses indivíduos. Trata-se de optar entre um modelo que promove a exclusão com uma alternativa inclusiva. Portanto, para que se tenha a intervenção como integrante do rol das estratégias de redução de danos, faz-se necessário o conteúdo ético, o substrato material traduzido no respeito à dignidade da pessoa humana.

\subsubsection{A vulnerabilidade como critério de eleição das ações de Redução de Danos}

O conceito atual de vulnerabilidade também foi construído a partir do direito humanitário significando, inicialmente, uma característica de pessoas ou comunidades fragilizadas, do ponto de vista jurídico ou político, na efetivação ou garantia de seus direitos fundamentais ${ }^{74}$.

No âmbito do direito penal e a partir dessas contribuições do direito humanitário, Zaffaroni $^{75}$ construiu sua ideia de culpabilidade por vulnerabilidade. Partindo da constatação da seletividade do sistema penal a vulnerabilidade se requalifica e, nessa dimensão, passa a ser o grau de risco de seleção que dada pessoa corre diante das agências penais.

Zaffaroni $^{76}$ admite, ainda, a possibilidade de reconhecimento de graus de vulnerabilidade de acordo com a probabilidade de seleção, conforme a situação que se ponha o indivíduo, tendo em conta que ela nada mais é que uma situação de perigo. Propõe, dessa forma, uma classificação:

"Esta situação de vulnerabilidade é produzida pelos fatores de
vulnerabilidade, que podem ser classificados em dois grandes grupos:
posição ou estado de vulnerabilidade e o esforço pessoal para a
vulnerabilidade. A posição ou estado de vulnerabilidade é predominantemente social (condicionada socialmente) e consiste no grau de risco ou perigo que a pessoa corre só por pertencer a uma classe, grupo, estrato social, minoria, etc., sempre mais ou menos amplo, como também por se

\footnotetext{
${ }^{74}$ CAVALLARI, Celi Denise; SODELLI, Marcelo. Redução de danos e vulnerabilidades enquanto estratégia preventiva nas escolas. In: SEIBEL, Sérgio Dario (Org.). Dependência de drogas. São Paulo: Atheneu, 2010. p. 801.

${ }^{75}$ ZAFFARONI, Eugenio Raúl. En busca de las penas perdidas: a perda de legitimidade do sistema penal. Rio de Janeiro: Revan, 1991. p. 245-246.

${ }^{76}$ Id. Ibid., p. 270.
} 
encaixar em um estereótipo, devido às características que a pessoa recebeu.

O esforço pessoal para a vulnerabilidade é predominantemente individual, consistindo no grau de perigo ou risco em que a pessoa se coloca em razão de um comportamento particular. A realização do 'injusto' é parte do esforço para a vulnerabilidade, na medida em que o tenha decidido com autonomia."

Partindo dessa classificação proposta por Zaffaroni, o conceito de vulnerabilidade foi novamente deslocado do restrito âmbito penal e reformulado em três dimensões, a saber, uma vulnerabilidade frente ao sistema penal, uma vulnerabilidade da comunidade e uma vulnerabilidade psico-social ${ }^{77}$.

Tendo como definida a primeira dimensão, a vulnerabilidade psico-social foi concebida como um traço subjetivo, pessoal e referido ao estado psíquico do indivíduo, embora tenha sido construído no âmbito social em função de um processo histórico de descumprimento dos direitos humanos fundamentais.

Finalmente, a vulnerabilidade da comunidade diz respeito às carências do próprio grupo social com relação a recursos institucionais de proteção à saúde, educação, segurança, etc., além de acesso ao mercado de trabalho, qualificação, enfim, condições de vida digna para qualquer agrupamento humano.

Podemos, portanto, definir três planos interdependentes de vulnerabilidade: vulnerabilidade individual (psico-social), vulnerabilidade social (comunitária) e a vulnerabilidade institucional (frente às agências estatais, penais ou não). Além disso, a vulnerabilidade é hoje entendida como uma situação dinâmica, isto é sujeita a mudanças e interações constantes, e, daí a necessidade de participação ativa dos indivíduos e da própria comunidade na elaboração e execução das intervenções preventivas de riscos e danos.

De qualquer sorte, a vulnerabilidade se mostra um valioso instrumento para a definição de estratégias que visem o planejamento e elaboração das ações políticas, uma vez que possibilita uma melhor compreensão das carências e necessidades, dando maior objetividade e incrementando o pragmatismo das intervenções.

Relativamente à política de drogas a utilização do conceito de vulnerabilidade possibilita, no plano individual, a identificação dos usuários mais propensos aos danos

\footnotetext{
${ }^{77}$ AYOS, Emilio Jorge. Delito y pobreza: espacios de intersección entre la política criminal y la política social argentina en la primera década del nuevo siglo. São Paulo: IBCCrim, 2010. p. 77.
} 
decorrentes do uso, tanto físicos como sociais, como, também, na dimensão social, de grupos de maior vulnerabilidade. São inúmeras as possibilidades que se abrem com a utilização desse instrumento uma vez que, como já visto, diversos elementos interferem na maior ou menor exposição ao risco e consumação de danos. Apenas exemplificativamente podemos elencar:

1 - Gênero- o sexo feminino é mais vulnerável a abusos sexuais e violências físicas. Além disso, é comum a prostituição como forma de sobrevivência, tudo implicando num aumento de riscos. O último censo penitenciário demonstrou que na população carcerária relativa às mulheres, $60 \%$ (sessenta por cento) delas estão presas pela prática de delitos tipificados na Lei de Drogas ${ }^{78}$.

2- Idade- usuários mais jovens estão expostos a maiores agravos sociais e a saúde.

3 - Vínculos institucionais e familiares - a inserção no trabalho formal ou informal e manutenção de vínculos familiares possibilitam um maior acesso às redes de atenção e cuidado.

4 - Escolaridade- baixa escolaridade implica em menor possibilidade de inserção no mercado de trabalho, menor disponibilidade financeira e, consequentemente, menores possibilidades de reinserção social.

5 - Droga de eleição e diferentes formas de apresentação e administração - drogas diversas apresentam efeitos e agravos distintos que podem ser potencializados pela sua diversificada forma de apresentação (v.g. : folha de coca, cocaína, pasta base, crack) e de administração (v.g.: inalada, fumada, injetada, etc.).

6 - Co-morbidades- agravos físicos e psíquicos decorrentes do uso de drogas implicam, frequentemente, num pior prognóstico com relação à retomada de uma qualidade de vida.

7 - Delitos, Conflito com a lei- prática de delitos, especialmente associação com o tráfico e, ainda, falta de mecanismos formais para a solução de conflitos (dívidas, compartilhamento de drogas ou insumos, etc) implicam numa maior exposição à violência.

Dessa forma, podemos adotar a vulnerabilidade, na sua tridimensionalidade, como critério formal, objetivo, para a ponderação e determinação das ações redutoras de riscos e

\footnotetext{
${ }^{78}$ INFOPEN - Sistema Integrado de Informações Penitenciárias. Brasília: Ministério da Justiça, jun. 2001.
} 
danos considerando as especificidades individuais e coletivas das pessoas, segmento ou comunidades, além do tipo de droga, sua apresentação e forma de administração.

A vulnerabilidade como critério indicativo das intervenções necessárias também é uma das opções adotadas por nossa Política Nacional sobre Drogas, tanto assim que estabelece "reconhecer as diferenças entre o usuário, a pessoa em uso indevido, o dependente e o traficante de drogas, tratando-os de forma diferenciadas", bem como "garantir, incentivar e articular, por intermédio do Conselho Nacional Antidrogas $\mathrm{CONAD}^{79}$, o desenvolvimento de estratégias de planejamento e avaliação nas políticas de educação, assistência social, saúde e segurança pública, em todos os campos relacionados às drogas" como seus pressupostos. Na mesma linha aponta como um de seus objetivos "reduzir as consequiências sociais e de saúde decorrentes do uso indevido de drogas para a pessoa, a comunidade e a sociedade".

Mais adiante, quando regulamenta tópico específico relativo às estratégias de redução de danos, a Política Nacional sobre Drogas adota como uma de suas diretrizes “orientar e estabelecer, com embasamento científico, intervenções e ações de redução de danos, considerando a qualidade de vida, o bem estar individual e comunitário, as características locais, o contexto de vulnerabilidade e o risco social”, bem como, "implementar políticas públicas de geração de trabalho e renda como elementos redutores de danos sociais".

Finalmente, no tocante a estudos, pesquisas e avaliações a Política Nacional adota como diretriz, dentre outras, "promover e realizar, periódica e regularmente, levantamentos abrangentes e sistemáticos sobre o consumo de drogas lícitas e ilícitas, incentivando e fomentando a realização de pesquisas dirigidas a parcelas da sociedade, considerando a enorme extensão territorial do país e as características regionais e sociais, além daquelas voltadas para populações específicas."

Mas, além de uma orientação programática conferida pela Política Nacional, a própria Lei 11.343/2006 acolhe o mesmo critério e, dessa forma legitima e fornece o enquadramento legal necessário à sua adoção. No seu Capítulo Ido seu Título II, quando estabelece os princípios e objetivos do Sistema Nacional de Políticas de Drogas, ao discorrer sobre os princípios reitores do sistema em seu artigo $4^{\circ}$, ela assim dispõe:

\footnotetext{
${ }^{79}$ Atual Conselho Nacional de Políticas sobre Drogas.
} 
“Art. $4^{o}$ São princípios do Sisnad:

$I-$

II - o respeito à diversidade e às especificidades populacionais existentes;

III- a promoção dos valores éticos, culturais e de cidadania do povo brasileiro, reconhecendo-os como fatores de proteção para o uso indevido de drogas e outros comportamentos correlacionados;

IX - a adoção de abordagem multidisciplinar que reconheça a interdependência e a natureza complementar das atividades de prevenção do uso indevido, atenção e reinserção social de usuários e dependentes de drogas, repressão da produção não autorizada e do tráfico ilícito de drogas;"

Mais adiante, no $\operatorname{artigo} 5^{\circ}$, ao definir seus objetivos destaca:

"I - contribuir para a inclusão social do cidadão, visando a torná-lo menos vulnerável a assumir comportamentos de risco para o uso indevido de drogas, seu tráfico ilícito e outros comportamentos correlacionados;"

Mas a dicção expressa, no sentido de fornecer o embasamento legal para acolher a vulnerabilidade como critério eletivo das ações, é encontrada no artigo 18, quando a legislação define no que constituem as atividades de prevenção:

"Art. 18 - Constituem atividades de prevenção do uso indevido de drogas, para efeito desta Lei, aquelas direcionadas para a redução dos fatores de vulnerabilidade e risco e para a promoção e o fortalecimento dos fatores de proteção."

Em seguida, no artigo 19, ela define os princípios e diretrizes que devem ser seguidas pelas atividades de prevenção:

"I - a adoção de conceitos objetivos e de fundamentação científica como forma de orientar as ações dos serviços públicos comunitários e privados e de evitar preconceitos e estigmatização das pessoas e dos serviços que as atendam;

IV - o compartilhamento de responsabilidade e a colaboração mútua com as instituições do setor privado e com os diversos segmentos sociais, incluindo usuários e dependentes de drogas e respectivos familiares, por meio de estabelecimento de parcerias; 
$V-a$ adoção de estratégias preventivas diferenciadas e adequadas às especificidades socioculturais das diversas populações, bem como das diferentes drogas utilizadas;

VII - o tratamento especial dirigido às parcelas mais vulneráveis da população, levando em consideração as suas necessidades específicas;"

Quanto às atividades de atenção e reinserção social de pessoas que usam drogas a Lei 11.343/2006, em seu artigo 22, define como seus princípios e diretrizes, dentre outros, os seguintes parâmetros:

"II - a adoção de estratégias diferenciadas de atenção e reinserção social do usuário e do dependente de drogas e respectivos familiares que considerem as suas peculiaridades socioculturais;

III - definição de projeto terapêutico individualizado, orientado para a inclusão social e para a redução de riscos e de danos sociais e à saúde;"

Dessa forma, alem de se mostrar, do ponto de vista teórico, um valioso instrumento para a identificação dos fatores de risco e dano nas suas variadas dimensões, a vulnerabilidade encontra a sua legitimação na Política Nacional de Drogas e seu fundamento legal na própria Lei $n^{\circ} 11.343 / 2006$, a atual Lei de Drogas. 


\section{PROGRAMAS DE REDUÇÃO DE DANOS E AS DROGAS}

\subsection{A Redução de danos: no marco do Proibicionismo}

Vale promover o confronto do modelo proibicionista com as estratégias de redução de danos para a verificação de seus alinhamentos ideológicos e suas peculiaridades formais e identificação de suas distintas formas de abordagem quando aplicados numa mesma ação de política pública relacionada às drogas.

Embora a redução de danos, em algumas formas de intervenção, possa ser adotada ainda que no marco de uma política proibicionista, ela se distingue, sobremaneira, das ações de cunho proibicionista-punitivo, que visam, em última análise, a imposição pela via penal de um comportamento único, a abstinência.

Para tanto vale confrontarmos seus modelos de intervenção, quando adotados em uma intervenção pública que se destina ao mesmo contexto e visa a mesma finalidade.

\subsubsection{Justiça Terapêutica X Justiça Restaurativa}

Diante das evidências do fracasso do Proibicionismo e, principalmente, frente à crise penitenciária decorrente da superpopulação carcerária criou-se, nos Estados Unidos da America, um programa denominado "Drug Courts" $" 80$ ou Tribunais para dependentes químicos que, no Brasil, acabou por receber o nome de justiça terapêutica. A base da abordagem preconizada pelo programa é a imposição de tratamento coercitivo aos usuários de drogas e que hoje encontra-se amplamente difundida nos Estados Unidos e possui inúmeros defensores no Brasil.

Deve ser destacada a evidente diferença existente entre o tratamento voluntário, considerado uma estratégia de redução de danos, e a imposição de tratamento compulsório, denominado de "justiça terapêutica", que faz parte de estratégia proibicionista, pois exige a abstinência, e situa o uso de droga no plano da moral.

${ }^{80}$ NATIONAL DRUG COURT INSTITUTE. Desenvolvimento e implementação de sistemas de Tribunais para dependentes químicos. Brasília: Embaixada dos Estados Unidos da América no Brasil, 1999. (Série Monografias 2). 
A adesão voluntária ao tratamento, preferencialmente oferecido pelo sistema público de saúde e fora do sistema penal, difere do modelo compulsório, pois não exige a "cura", e depende do compromisso e envolvimento da pessoa a ele submetida que pode buscar a abstinência através da moderação de seu uso ou simplesmente adotar hábitos de temperança na utilização das substâncias psicoativas.

No polo oposto está a abordagem coercitiva que, conforme a própria Associação Nacional de Justiça Terapêutica, "pode ser compreendida como um conjunto de medidas que visam aumentar a possibilidade de que infratores usuários e dependentes de drogas entrem e permaneçam em tratamento, modificando seus anteriores comportamentos delituosos para comportamentos socialmente adequados".

Dessa forma, o tratamento compulsório tem por objetivo declarado "modificar" comportamentos qualificados de negativos, rotulados como "delituosos", transformando seus autores em seres socialmente adequados.

A Justiça Terapêutica vem sendo anunciada como medida "humanista" e “alternativa" contudo, o tratamento não voluntário representa, na verdade, um reforço da política proibicionista, uma vez que justifica a necessidade de criminalização da conduta de posse de entorpecentes como forma de fornecer ao Estado um instrumento supostamente apto a coagir os usuários a abandonarem a droga.

Pretende, portanto, utilizar o direito penal em prol da modificação da personalidade do sujeito, visando à adaptação individual a uma sociedade que defende a abstinência das drogas consideradas ilícitas, ao mesmo tempo em que sempre incentivou o uso de drogas lícitas. O uso de drogas ilícitas é visto, sob esta perspectiva, como uma imoralidade a ser combatida.

Em sentido oposto, as estratégias de redução de danos, dentre as quais o tratamento voluntário e gratuito nas redes de saúde pública, baseiam-se no respeito à dignidade do usuário, sua autonomia e liberdade individual, têm por meta a moderação, e por isso constituem uma alternativa ao proibicionismo, ainda que possam coexistir em sistemas moderados, como é o caso de diversos países europeus e mesmo o Brasil.

É necessário, dessa forma, estabelecer as diferenças entre o modelo proibicionista, que adota o máximo controle penal sobre a venda e consumo de substâncias etiquetadas como ilícitas, preferencialmente mediante o uso da pena de prisão como meio de coerção, 
ligada a um ideal de abstinência, e os modelos alternativos de controle, que preconizam a redução da ingerência do sistema penal sobre os consumidores de psicotrópicos.

A Justiça terapêutica adota o discurso proibicionista-punitivo, pois limita seus horizontes ao direito penal, olvidando da existência de medidas alternativas que podem e devem ser aplicadas fora do campo punitivista. Além disso, violam princípios ligados às liberdades públicas, notadamente a dignidade do usuário de drogas, que não é simplesmente um alienado que precisa ser tutelado pelo Estado, mas uma pessoa que fez opções por hábitos de vida que, mesmo não sendo necessariamente saudáveis, causam eventualmente danos pessoais, e não pode por isso ser estigmatizada ou tratada, aprioristicamente, como alguém absolutamente incapaz.

Dessa forma, as estratégias de redução de danos, que visam a adoção de um tratamento humanista de temperança no uso de drogas e de respeito ao usuário, não podem ser confundidas com um modelo que tem por meta a defesa social e que trata a pessoa que usa drogas, generalizadamente, como um enfermo perigoso que deve ser tutelado pelo Estado de forma a não causar danos à sociedade.

Pois bem, se do ponto de vista político ideológico podemos estabelecer uma clara distinção entre o modelo adotado pela Justiça Terapêutica, com clara filiação ao proibicionismo-punitivo, e as estratégias de redução de danos que trabalham num horizonte antiproibicionista, embora não sejam absolutamente incompatíveis com modelos políticos mais moderados, não podemos esquecer que sob o aspecto legal as "Drug Courts" foram introduzidas no Brasil, ainda sob a vigência de leis (Lei $n^{\circ}$ 6.368/76 e a Lei $n^{\circ} 10.409 / 02$ ) que previam uma privação de liberdade de seis meses a dois anos para a posse de drogas para uso próprio.

Portanto, é necessário analisarmos se a nova Lei de Drogas prevê ou não a possibilidade de imposição de tratamento como pena. Deve ser desde logo esclarecido que a nova lei aborda o tema de forma transversal, indireta, adotando uma técnica legislativa que tem dado margem às mais diversas interpretações. Contudo, numa exegese sistemática de seus dispositivos, pode-se afirmar com certeza que o novo diploma legal não admite a submissão de acusados a tratamento compulsório.

Deve ser inicialmente considerado que o arcabouço principiológico da nova legislação experimentou significativas modificações e prevê, expressamente, como sua base ética: "o respeito aos direitos fundamentais da pessoa humana, especialmente quanto 
à sua autonomia e à sua liberdade" (art. $4^{\mathrm{o}}$. inciso I); “o respeito à diversidade e às especificidades populacionais existentes" (inciso II); além de ter como meta o "fortalecimento da autonomia e da responsabilidade individual em relação ao uso indevido de drogas", no seu art. 19, III.

Por outro lado, as sanções previstas no artigo 28 da nova lei para "quem adquirir, guardar, tiver em depósito, transportar ou trouxer consigo, para consumo pessoal, drogas sem autorização ou em desacordo com determinação legal ou regulamentar" demonstram uma nítida opção pela descarcerização, embora mantendo a criminalização da conduta e contêm as seguintes modalidades: I - advertência sobre os efeitos das drogas; II - prestação de serviços à comunidade; III - medida educativa de comparecimento a programa ou curso educativo. Relativamente às duas últimas espécies de pena previstas, é estabelecida uma duração máxima de cinco meses $\left(\S 3^{\circ}\right.$.), podendo ser ampliada para dez meses, no máximo, na hipótese de reincidência $\left(\S 4^{\circ}\right.$.). Em caso de recalcitrância ou descumprimento por parte do agente o magistrado poderá submetê-lo a admoestação verbal ou impor-lhe uma multa, sucessivamente $\left(\S 6^{\circ}\right)$.

A nova disciplina estabelece ainda que "a prestação de serviços à comunidade será cumprida em programas comunitários, entidades educacionais ou assistenciais, hospitais, estabelecimentos congêneres, públicos ou privados sem fins lucrativos, que se ocupem, preferencialmente, da prevenção do consumo ou da recuperação de usuários e dependentes de drogas" $\left(\S 5^{\circ}.\right)$.

Há, ainda, a previsão contida no $\S 7^{\circ}$ do artigo 28 , que estabelece um direito do usuário colhido pela agência penal, na medida em que garante a disponibilidade de estabelecimento de saúde que lhe ofereça tratamento especializado e gratuito, preferencialmente ambulatorial, o que não se confunde com o tratamento sob coerção de pena, conforme o modelo adotado pela justiça terapêutica.

Resta claro, portanto, que o legislador optou por rejeitar a pena de tratamento. Em reforço dessa conclusão deve ser lembrado que referida sanção havia sido expressamente prevista no Substitutivo da Câmara dos Deputados ao Projeto de Lei n ${ }^{\circ}$ 7.134-A, de 2002, do Senado Federal (PLS No 115/02 na Casa de origem), no $\S 2^{\circ}$. do artigo 28, cuja redação afasta possíveis dúvidas: 
"O juiz poderá, na homologação da transação penal a que se refere a Lei $\mathrm{n}^{\text {o }}$ 9.099, de 26 de setembro de 1995, que dispõe sobre os Juizados Especiais Criminais, ou na sentença, encaminhar o agente para tratamento, com base em avaliação que ateste a necessidade, em função de risco à integridade física e emocional da própria pessoa, de sua família ou da comunidade, realizada por profissional de saúde com competência específica na forma da lei”.

Contudo, a imposição de tratamento como pena, antecipada ou não, acabou rejeitada no projeto aprovado pelo Senado e torna-se até mesmo acaciano afirmar que por ter sido expressamente repelida pelo legislador, o tratamento compulsório nos moldes pretendido pelos defensores da justiça terapêutica padece da falta de amparo legal, nos termos da Lei 11.343/2006.

Considerando ainda que a nova lei adotou fundamentos éticos que realinharam a Política Nacional de Drogas compatibilizando-a com os direitos e garantias constitucionais insculpidos na Constituição Federal, importa reconhecer que a imposição de tratamento como pena afronta o princípio da liberdade individual, da privacidade e da intimidade (Art. $5^{\circ}$, inciso X), uma vez que é inadmissível que, num Estado Democrático de Direito, um cidadão se veja obrigado a submeter-se a tratamento de saúde, qualquer que seja, contra sua vontade, exceção feita a casos extremos e individualizados, quando a vontade não possa ser aferida ou que importe em grave risco à pessoa ou terceiros, expressamente previstos em lei.

A saúde pública também desautoriza a proposta de terapia compulsória, uma vez que as evidências científicas apontam no sentido de que o tratamento deve ser um processo dialógico, baseado no desejo do cidadão dependente químico. Ademais, a pena de tratamento despreza a necessidade de uma avaliação individualizada na abordagem terapêutica, pois ignora as diferenças entre os usuários ocasionais, eventuais e dependentes e desconsidera a existência de inúmeros tipos de psicotrópicos com características e potencialidades distintas. ${ }^{81}$

Esse foi o entendimento adotado na declaração de intenções conjunta, publicada em 14.12.2002, pelos Conselho Federal e Conselhos Regionais de Psicologia, que afirmaram:

"O Psicólogo, enquanto membro de equipes multiprofissionais da área de saúde, não pode atuar como agente executor de penalidade a ser aplicada ao indivíduo.

\footnotetext{
${ }^{81}$ REGHELIN, Elisangela Melo. op. cit., p. 165.
} 
A "Justiça Terapêutica", ao tratar a saúde como um dever e não como um direito, fere o Código de Ética do Psicólogo no Princípio Fundamental VII, que, balizado na Declaração Universal dos Direitos Humanos, aprovada em 10.12.1948 pela Assembléia Geral das Nações Unidas, prega que o acesso à saúde é um direito universal e não um dever a ser imposto."

Os dispositivos do novo Código de Ética Médica também não permitem interpretação divergente daquela expressada na resolução do Conselho Federal de Psicologia, posto que reforçaram a autonomia do paciente e sua autodeterminação na relação médico-paciente, sendo que este fundamento adquiriu especial relevância no trinômio que se completa com a beneficência da conduta e competência do médico.

Dessa forma, a previsão contida no inciso III do artigo 28 da Lei n. 11.343/06, de “comparecimento a programa ou curso educativo", se cotejada com tais princípios, não pode ser dilargada a ponto de incluir a possibilidade de se impor, ao cidadão acusado por posse de drogas, a frequência a qualquer outra modalidade de tratamento compulsório.

Não obstante todo o embasamento ético-político e legal até aqui apontado, o fato é que passados quase seis anos de vigência da nova Lei de Drogas a aplicação das medidas educativas, introduzidas em nosso ordenamento como penas aplicáveis aos autores da conduta de posse de drogas para uso pessoal, continuam a gerar perplexidade no meio judiciário e ainda não encontrou um modelo paradigmático. Pode-se deparar, no dia a dia forense, com as mais diversas e mesmo contraditórias interpretações.

A medida de advertência sobre os efeitos das drogas viu-se praticamente convertida num pito, uma reprimenda por vezes fundamentada em razões de ordem moral, por outras, em concepções religiosas. São comuns, ainda, as burocráticas e constrangedoras audiências coletivas, onde um público constituído por supostos autores da conduta é instado a aceitar a transação penal consistente numa hipótese também não prevista em lei, vale dizer, as banalizadas cestas básicas. Essas práticas somente contribuem para desautorizar ainda mais a nossa já tão combalida Justiça Penal. 
E, mais, a adoção do modelo de Justiça Terapêutica continua sendo prática cotidiana $^{82}$, à falta de indicação de alternativas mais conformadas às diretrizes éticopolíticas introduzidas em nosso sistema pela nova Lei de Drogas.

Ciente da falta de uma diretriz que uniformizasse o entendimento em torno das medidas educativas indicadas no art. 28 e, ao mesmo tempo, indicasse boas práticas para o desempenho das atividades judiciárias que fossem compatíveis com os novos princípios norteadores da Lei de Drogas, o Conselho Nacional de Justiça, por intermédio de sua corregedoria, editou o Provimento $\mathrm{n}^{\circ} 4$, que define medidas com vistas à eficácia e ao bom desempenho da atividade judiciária na implantação das atividades de atenção e de reinserção social de usuários ou dependentes de drogas. Através desse ato o Conselho Nacional de Justiça estabeleceu:

"Art. $1^{\circ} \mathrm{O}$ atendimento aos usuários de drogas encaminhados ao Poder Judiciário em razão de termo circunstanciado lavrado por infração prevista no artigo 28 da Lei 11.343/2006 será multidisciplinar, na forma do art. $4^{\circ}$, IX, da mesma Lei.

Parágrafo único. Os Tribunais de Justiça deverão estabelecer, no prazo de 120 (cento e vinte) dias, equipes multiprofissionais habilitadas para captar redes de atendimento aos usuários de drogas e propor aos magistrados a medida mais adequada para cada caso.

Art. $2^{\circ}$ A composição e formação das equipes multiprofissionais se fará por capacitação dos servidores do Poder Judiciário ou de forma mista, por convênios com instituições de ensino, entidades públicas e privadas destinadas ao atendimento de usuários de drogas.

$\S 1^{\circ}$ Os Tribunais deverão formar número suficiente de equipes para o atendimento pronto e eficaz em todas as comarcas.

$\S 2^{\circ} \mathrm{O}$ treinamento deve ser continuado e ministrado de forma a facilitar a comunicação efetiva com o usuário de drogas.

Art. $3^{\circ}$ Os Tribunais, no prazo de 120 (cento e vinte) dias, deverão providenciar a capacitação dos juízes na questão drogas, em parceria com as Escolas de Magistratura, observados os princípios e diretrizes definidos no artigo 19 da Lei 11.343/2006.

$\S 1^{\circ}$ O juiz atuará em harmonia com a equipe multiprofissional para individualização da pena ou medida cabível como transação penal ou condenação.

$\S 2^{\circ}$ A atuação do Poder Judiciário limitar-se-á ao encaminhamento do usuário de drogas à rede de tratamento, não lhe cabendo determinar o tipo de tratamento, sua duração, nem condicionar o fim do processo criminal à constatação de cura ou recuperação.

\footnotetext{
${ }^{82}$ A Secretaria da Justiça e o Ministério Público do Estado de São Paulo têm o modelo como referência e o indicam, a partir das experiências realizadas no Juizado Especial Criminal de Santana que trabalha em convênio com grupos de auto-ajuda (AAA, Narcóticos Anônimos etc.)
} 
Art. $4^{\circ}$ Os Tribunais de Justiça manterão banco de dados das entidades públicas e privadas (redes de serviços) que atendam aos usuários de drogas dentro das diretrizes do Sistema Nacional de Políticas Públicas sobre Drogas - SISNAD."

Posteriormente foi editado novo provimento, de número 9, para promover a mesma reestruturação nos Juizados da Infância e Juventude e nas Varas especializadas visando a adoção das mesmas medidas e a observação da metodologia de trabalho indicada no provimento anterior.

Para implantar a metodologia indicada e atender às previsões dos artigos $2^{\circ}$ e $3^{\circ}$ do Provimento $\mathrm{n}^{\mathrm{o}} 4$ do CNJ, o Ministério da Justiça, através da Secretaria Nacional de Políticas sobre Drogas, SENAD, e o Conselho Nacional de Justiça, CNJ, firmaram uma parceria e, em conjunto com a Universidade de São Paulo, representada pelas Faculdades de Medicina e de Direito, elaboraram o programa designado "Integração de Competências no Desempenho da Atividade Judiciária com usuários e dependentes de Drogas" 83.

Essa parceria visa a construção de respostas intersetoriais nas áreas jurídica, da educação, saúde e assistência social que apresentem medidas interdisciplinares para atenção ao fenômeno do uso de drogas em toda sua dimensão e diferentes interfaces.

Numa das fases do projeto será realizada pesquisa de caráter nacional com o objetivo de identificar boas práticas e metodologias eficazes na individualização das medidas socioeducativas e medidas protetivas, com a meta de difundí-las por todo território nacional.

Um modo de promover e compartilhar essas informações, métodos e conhecimentos é a realização de cursos a distância. O conteúdo do curso envolve uma visão geral do tema drogas, sob a ótica do Direito, da Saúde Pública e Ciências Sociais e é voltado aos operadores do direito e profissionais que atuam na área psicossocial dos Juizados Especiais Criminais (JECrims) e Varas da Infância e da Juventude (VIJs), buscando capacitá-los fornecendo as bases teóricas para uma adequada atuação multiprofissional na atenção aos usuários de drogas, incluindo a orientação sobre estratégias de articulação visando a formação de rede de serviços existente na própria comunidade.

\footnotetext{
${ }^{83}$ Vide anexo 3.
} 
O modelo multiprofissional e articulado com a rede local possibilitará não apenas aprimorar o atendimento, mas identificar novos parceiros ampliando as alternativas na execução das penas e medidas aplicadas em busca de um sistema mais eficiente e que apresente resultados positivos, como a queda dos índices de reincidência e o aperfeiçoamento dos serviços judiciários.

Como já foi analisado, a nova Lei de Drogas, introduziu uma modificação significativa na abordagem das pessoas que usam drogas, sejam usuários ou dependentes. No atendimento às pessoas encaminhadas aos Juizados, o modelo proposto é a conversão da audiência de advertência numa prática restaurativa ${ }^{84}$. O cidadão será atendido pela equipe multidisciplinar e poderá receber orientação sobre os diversos aspectos relacionados ao uso indevido de drogas, buscando entender o seu efetivo comprometimento e as possibilidades e alternativas disponíveis com o propósito de se estabelecer uma medida adequada e consensual para cada indivíduo atendido.

Além disso, o encontro servirá para que a equipe multidisciplinar, valendo-se da metodologia de intervenção breve ${ }^{85}$, avalie o real comprometimento do indivíduo com as drogas, se usuário eventual, habitual ou já num estágio de dependência, para possibilitar a indicação àquela pessoa das alternativas disponíveis adequadas ao seu caso e, ainda, propor ao magistrado a medida que melhor atende às necessidades do indivíduo.

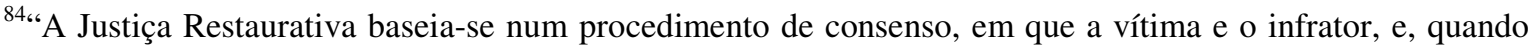
apropriado, outras pessoas ou membros da comunidade afetados pelo crime, como sujeitos centrais, participam coletiva e ativamente na construção de soluções para a cura das feridas, dos traumas e perdas causados pelo crime. Trata-se de um processo estritamente voluntário, relativamente informal, a ter lugar preferencialmente em espaços comunitários, sem o peso e o ritual solene da arquitetura do cenário judiciário, intervindo um ou mais mediadores ou facilitadores e podendo ser utilizadas técnicas de mediação, conciliação e transação para se alcançar o resultado restaurativo, ou seja, um acordo objetivando suprir as necessidades individuais e coletivas das partes e se lograr a reintegração social da vítima e do infrator". Ver: PINTO, R. Sócrates Gomes. Justiça restaurativa é possível no Brasil? In: SLAKMON, C., DE VITTO, R.; GOMES PINTO, R. S. (Orgs.). Justiça restaurativa. Brasília - DF: Ministério da Justiça e Programa das Nações Unidas para o Desenvolvimento - PNUD, 2005. p. 19-39.

${ }^{85}$ “A intervenção breve (IB) é uma técnica mais estruturada que o aconselhamento, mas não mais complexa. Possui um formato claro e simples, pode ser utilizada por qualquer profissional da saúde sem a necessidade de longos e custosos treinamentos e em qualquer local de tratamento. Comprovadamente, tem sido indicada até para pacientes gravemente comprometidos, em fases iniciais de tratamento, pois intervir minimamente é melhor que não o fazer. Quando tais intervenções são estruturadas em até quatro sessões produzem impacto igual ou maior que tratamentos mais extensivos para a dependência de álcool. As IBs utilizam técnicas comportamentais para alcançar a abstinência ou a moderação por meio de informações e recomendações objetivas, como a redução do consumo para atingir a abstinência, a realização de exames complementares e outros recursos. Depois de estabelecida a meta, desenvolvem-se a automonitorização, identificação das situações de risco e estratégias para evitar o retorno ao padrão de beber problemático.” MARQUES, A. C. P. R. A avaliação do uso, abuso e dependência de álcool, tabaco e outras substâncias psicotrópicas e a intervenção breve. In: SEIBEL, Sérgio Dario (Org.). Dependência de drogas. São Paulo: Atheneu, 2010. p. 322.
} 
Além de serem orientadas para as questões relacionadas ao consumo de drogas e suas alternativas, essas pessoas poderão ser encaminhadas para o cumprimento de prestação de serviços em programas comunitários de tratamento e reinserção social, em instituições identificadas na própria comunidade e que compõem a rede de atenção local, formada pela equipe do judiciário.

Dessa forma, muito além da aplicação moralista ou burocrática da lei, a ação dos Juizados Especiais Criminais, diante do usuário e do dependente de drogas, possibilitará uma prática restaurativa, criando uma oportunidade para que eles possam, a partir de um encontro dialógico, repensar sua relação com a droga, assim como as implicações desse comportamento nos diferentes domínios de sua vida.

Desse modo, o modelo formulado supera a abordagem tradicional e incorpora uma aproximação respeitosa com o atendido, dentro dos princípios preconizados pela Redução de Danos, possibilitando a busca consensual de alternativas para o tratamento, se necessário, e perspectivas concretas de reinserção social.

\subsection{Programas de Redução de Danos para Cocaína/Crack}

\subsubsection{O "higienismo" $\mathrm{X}$ consultórios de rua e locais de acolhimento}

Antes de abordarmos as questões relativas às políticas públicas recentemente adotadas para usuários de crack é necessário desmistificar algumas informações que são constantemente veiculadas pelos meios de comunicação social e que, após alguns anos de realização de pesquisas específicas sobre essa modalidade de uso da coca e sua "cultura", não se sustentam, frente às evidências científicas.

O crack é, na realidade, uma forma de apresentação da cocaína que possibilita seu uso pela via inalatória. Sua obtenção é simples e caseira, podendo ser realizada tanto a partir do cloridrato de cocaína quanto da pasta-base. No caso específico do cloridrato de cocaína, a mistura com bicarbonato de sódio resulta num cristal (pedra) próprio para ser consumido na forma fumada, o que não seria possível na forma refinada da cocaína. A pasta base, composta por sulfato de cocaína, devido a sua natureza alcalina, também pode ser fumada assim como o crack. 
As primeiras notícias sobre o uso de crack dão conta de que tenha surgido em meados dos anos 80 em bairros pobres de Los Angeles, Nova York e Miami, sua utilização se dava em grupos e em locais abandonados e precários que ficaram conhecidas como crack houses. Quando acesos para serem fumados os cristais estralavam (cracking), dando origem ao nome pelo qual hoje é conhecido esse subproduto da coca. Os efeitos produzidos nessa modalidade de uso são de grande intensidade e curta duração, provocando grande fissura e compulsão pela utilização de nova dose ${ }^{86}$.

Seu baixo custo, a facilidade em sua obtenção e a otimização com relação ao volume possível de ser produzido a partir do produto original, conjugados à possibilidade de ser comercializado em doses (pedras), contribuíram para a rápida expansão do comércio de crack, possibilitando a popularização do uso da cocaína que era, até então, uma droga típica das classes sociais privilegiadas.

Com relação ao Brasil, as evidências apontam que o crack surgiu na transição dos anos 80/90 na periferia de São Paulo, portanto também em regiões de exclusão social, tendo em seguida "migrado" para a região da Estação da Luz, local que a partir de então passou a ser conhecido como "cracolândia". Em situações episódicas o consumo se espalhou para outros pontos da cidade, especialmente em função de ações policiais naquela região, mas cessada a intervenção torna a se aglutinar numa espécie de gueto, em decorrência da situação de apartamento social.

Embora atualmente o uso de crack possa ser observado em todas as classes sociais, o perfil do usuário segue sendo o de jovens, desempregados, com baixa escolaridade e baixo poder aquisitivo, provenientes de famílias desestruturadas, com antecedentes de uso de múltiplas drogas e comportamento sexual de risco ${ }^{87}$. Essas características de vulnerabilidades pessoais dos usuários, aliadas às vulnerabilidades sócio-políticas: cena de uso, criminalização da conduta, estigmatização e preconceito, falta de acesso ou não aderência aos serviços oferecidos, militam para dificultar sua adesão aos serviços de atenção disponíveis sendo necessárias a adoção de abordagens mais diversificadas ${ }^{88}$.

Foram realizados, ainda, estudos que determinaram aspectos socioculturais do uso do crack ou a subcultura própria dessa população:

\footnotetext{
${ }^{86}$ PERRENOUD, L. O.; RIBEIRO M. Histórico do consumo de crack no Brasil e no Mundo. In: RIBEIRO, M.; LARANJEIRA, R. (Orgs.). O tratamento do usuário de crack. 2. ed. Porto Alegre: Artmed, 2012. p. 33. Ver ainda, DOMANICO, Andrea. op. cit., p. 13.

${ }^{87}$ PERRENOUD, L. O.; RIBEIRO M. op. cit., p. 34.

${ }^{88}$ Id. Ibid., p. 36.
} 
"Quando se considera o uso do crack, que em geral ocorre por longos
períodos contínuos (também chamados de binge), o usuário se esgota
física e psiquicamente, abstendo-se dos cuidados básicos à saúde:
alimentação, sono e procedimentos de higiene pessoal. Somado a isso, há
o compartilhamento dos acessórios para o uso da droga, o que pode
predispor, entre uma série de complicações, a situaçóes como
contaminações por tuberculose ou hepatite. Assim, o usuário de crack
geralmente tem efeitos negativos no status geral da saúde física, uma vez
que seus pensamentos e comportamentos concentram-se em tornar
possível o uso da droga, deixando de lado o autocuidado.

Além dessa série de prejuízos descritos, somam-se ainda outras complicações associadas ao padrão de uso compulsivo. Esses danos incontestes, especialmente aqueles relacionados à ruptura de vínculos sociais (descaso com família e emprego) e ao envolvimento com atividades ilícitas.

Haasen e Krausz, também observam que os homicídios relacionados ao crack não estão ligados diretamente aos efeitos psicofarmacológicos da droga. Eles estariam relacionados aos riscos apresentados pelo sistema ilícito de venda de drogas. No Brasil, especialmente, os homicídios correspondem a importante parte das mortes por causas externas, sendo muito dessa violência relacionada ao uso de álcool e drogas ilícitas.

Ainda no que se refere ao estilo de vida dos usuários, além dos meios violentos como tentativa de arrecadar recursos para o uso, existe também a prostituição com múltiplos parceiros sexuais, aumentando as chances de contaminação por $H I V^{89}$ ".

Talvez a única ressalva que se possa fazer às observações colhidas pelas pesquisas das reconhecidas cientistas seja o fato de que, na verdade, não se trata de um estilo de vida, mas sim uma situação de exclusão social. De qualquer sorte, já existe um conjunto consistente de dados e informações científicas que servem para nortear a formulação de políticas públicas para a atenção a essa população específica. Note-se que os fatores elencados na pesquisa são, todos eles, fatores de risco ou de efetiva lesão, apontam vulnerabilidades de ordem subjetiva e sóciopolíticas-econômicas que poderiam nortear a formulação de estratégias no campo da saúde, assistência social e mesmo jurídicas que possibilitassem, senão a reversão, ao menos a atenuação desse quadro de exclusão.

Pois bem, apesar disso, essa população permaneceu, desde o surgimento das "cracolândias", portanto há quase duas décadas, confinada em guetos e em quase total estado de abandono, pois a atenção se resumia à atuação de ONGS e grupos religiosos,

\footnotetext{
${ }^{89}$ RIBEIRO, L. A.; NAPPO, S. A.; SANCHEZ, Z. V. D. M. Aspectos socioculturais do consumo de crack. In: RIBEIRO, M.; LARANJEIRA, R. (Orgs.). O tratamento do usuário de crack. 2. ed. Porto Alegre: Artmed, 2012. p. 52-53.
} 
sem uma estratégia consistente e contínua da parte do estado, considerando todos os seus entes federativos, que articulasse as diferentes ações de atenção e reinserção social, considerando os diversos e já conhecidos fatores de vulnerabilidade dos usuários de crack.

Em maio de 2010 foi lançado pelo Governo Federal o Plano Integrado de Enfrentamento ao Crack e outras Drogas $^{90}$ nele sendo estabelecido, dentre seus fundamentos: "integração e a articulação permanente entre as políticas e ações de saúde, assistência social, segurança pública, educação, desporto, cultura, direitos humanos, juventude, entre outras, em consonância com os pressupostos, diretrizes e objetivos da Política Nacional sobre Drogas" e um elenco de seis objetivos gerais, dentre eles os de "estruturar, integrar, articular e ampliar as ações voltadas à prevenção do uso, tratamento e reinserção social de usuários de crack e outras drogas, contemplando a participação dos familiares e a atenção aos públicos vulneráveis, entre outros, crianças, adolescentes e população em situação de rua" e "estruturar, ampliar e fortalecer as redes de atenção à saúde e de assistência social para usuários de crack e outras drogas, por meio da articulação das ações do Sistema Único de Saúde - SUS com as ações do Sistema Único de Assistência Social-SUAS".

Contudo, dadas as contingências próprias do período eleitoral que se avizinhava, o plano continuou sendo uma declaração de intenções e não saiu do papel, servindo apenas como argumento político.

Com a posse do novo governo federal, o referido projeto permaneceu em fase de gestação, sendo honesto assinalar que os órgãos de governo que têm atribuição pela condução de políticas públicas nesse campo, especialmente a Secretaria Nacional de Políticas sobre Drogas agora novamente sob o comando do Ministério da Justiça, vem desenvolvendo projetos específicos para a requalificação dos operadores do Direito na atenção aos usuários e dependentes de drogas (Anexo 3) bem como, numa parceria com a Fiocruz, vem realizando o primeiro levantamento epidemiológico nacional sobre o uso de crack.

O ano de 2011 transcorria sem percalços, antes pelo contrário, com relação a esse complexo fenômeno que se convencionou denominar como a "questão das drogas" o clima era de ufanismo midiático frente à nova política implementada na cidade do Rio de Janeiro, sinteticamente denominada de "UPP", vale dizer Unidade de Polícia Pacificadora.

\footnotetext{
${ }^{90}$ Vide anexo 4.
} 
Com a responsabilidade de sediar uma série de grandes eventos esportivos, a cidade do Rio de Janeiro reassumiu seu papel de destaque internacional e não poderia permanecer, conforme se alardeava, à mercê da criminalidade organizada, especialmente a organização denominada "Comando Vermelho". A cidade precisava ser pacificada e, nessa medida, foi sendo promovida a retomada de inúmeras favelas sediadas em morros cariocas, agora eufemisticamente denominadas comunidades, e nelas instaladas as chamadas UPPs, que permanecem aquarteladas, como garantes da ordem pública reafirmada, nas agora designadas "comunidades pacificadas". Junto com a ação militar, é honesto que se diga, vêm sendo implantados uma série de serviços públicos e privados e as favelas vêm sofrendo um processo de reurbanização ${ }^{91}$.

Em meio a esse clima de recuperação dos espaços urbanos, a Secretaria Municipal de Assistência Social da Prefeitura do Rio de Janeiro publicou e colocou em prática a sua resolução no 20/2011 de 27/05/2011, intitulada Protocolo de Abordagem à Pessoa em Situação de Rua que, em resumo, autoriza a adoção do sistema de internação compulsória para crianças e adolescentes menores de idade usuários de crack em situação em rua.

Munidos de mandados genéricos, expedidos pelo Juizado da Infância e Juventude da Comarca, os servidores da Secretaria passaram a recolher crianças e adolescentes em situação de rua, notadamente na região central onde está localizada a "cracolândia" carioca, e acompanhá-las à Delegacia de Proteção à Criança e ao Adolescente - DPCA para verificação de existência de mandado de busca e apreensão de menor e depois encaminhá-las à unidade de acolhimento, que tinha por obrigação impedir a evasão daqueles indivíduos, o que, em última análise, representa a prisão da pessoa arrebatada das ruas, tudo em conformidade com o artigo $5^{\circ}$, incisos XI e XV da citada resolução. Instalou-

\footnotetext{
${ }^{91}$ Embora não seja esse o propósito do presente trabalho uma vez que tal empreitada demandaria material para várias pesquisas nas mais diversas áreas que têm a violência como seu objeto, não se pode deixar de comentar que, a despeito de todo o aparente apoio da população carioca e o otimismo com o programa em comento, as "comunidades pacificadas" foram invadidas pelas forças armadas, que comandaram as operações, realizadas em conjunto com a Força Nacional e as polícias estaduais (com destaque para o cinematográfico BOPE), num verdadeiro "teatro de guerra". Tudo com transmissão ao vivo pelas redes nacionais de televisão, para o gozo do telespectador brasileiro, especialmente os moradores da zona sul carioca, que a tudo acompanhavam torcendo pela vitória do Capitão Nascimento. As populações dessas regiões invadidas tiveram seus direitos civis relativizados, quando não suprimidos, e foram vítimas de incontáveis abusos e violências, todos eles já fartamente documentados, e permanecem, até os dias de hoje, sob o império de um mal disfarçado Estado de Sítio.
} 
se, portanto, na cidade do Rio de Janeiro, a possibilidade de internação compulsória em massa, num sanitarismo típico do Dr. Simão Bacamarte. ${ }^{92}$

Inúmeras entidades da sociedade civil apresentaram seus protestos e denúncias, dentre elas a $\mathrm{OAB} / \mathrm{RJ}$ que organizou uma audiência pública e apresentou moção de repúdio à ação Municipal. O Conselho Nacional de Assistência Social (CNAS) classificou as ações como "práticas punitivas" e "higienistas", que negam o "direito à cidadania, em total desrespeito aos direitos arduamente conquistados na Constituição Federal, contemplados no Estatuto da Criança e do Adolescente - ECA, no Sistema Único da Saúde - SUS e no Sistema Único da Assistência Social - SUAS".

O próprio CONANDA - Conselho Nacional dos Direitos da Criança e do Adolescente - publicou nota técnica onde, depois de analisar detidamente cada dispositivo legal infringido pela ação política adotada pela Secretaria, destaca que " de todo o exposto, no exercício de sua função como órgão nacional de controle da política de direitos das crianças no Brasil, o CONANDA, pelos motivos acima expostos, declara ilegal a Resolução no 20, de maio de 2011, da Secretaria Municipal de Assistência Social do Rio de Janeiro, que institui o Protocolo de Abordagem da Pessoa em Situação de Rua, por não ser este o órgão com atribuição para deliberar as políticas de proteção especial à criança e ao adolescente, bem como por inobservância das normativas nacionais e internacionais que versam sobre os direitos da criança e do adolescente, assim como a política nacional de atendimento à saúde mental, sugerindo seu imediato sobrestamento."

A situação, de qualquer modo, não foi resolvida e as crianças e adolescentes permaneceram custodiados pela Secretaria que se viu obrigada, diante das denúncias e protestos, a adequar as condições das unidades de acolhimento e sobrestar as ações de recolhimento até que houvesse uma definição jurídica sobre a legalidade do procedimento.

Mas, como não poderia deixar de ser, a intervenção da Prefeitura carioca ganhou simpatizantes e o Poder Executivo paulistano manifestou a intenção de lançar um programa semelhante para a região da Luz, a "cracolândia" paulistana. A ação só não se consumou porque várias entidades da sociedade civil já haviam se articulado e manifestado sua oposição. Passou-se, então, para a realização de inúmeras audiências públicas para discussão da medida, que se viu reiteradamente rechaçada. Apesar da rejeição inicial, foi

\footnotetext{
${ }^{92}$ ASSIS, Machado de. O alienista. In: 50 contos. Machado de Assis: seleção, introdução e notas John Gledson. São Paulo: Companhia das Letras, 2007.
} 
articulada, em conjunto com o Tribunal de Justiça do Estado de São Paulo, a criação de um posto móvel do Juizado da Infância e Juventude, na região da Luz, onde um magistrado ficaria à disposição para avaliar e decidir, individualizadamente, a necessidade ou não da internação de crianças e adolescentes em situação de rua e usuários de drogas.

Diante da precipitação do problema frente as medidas adotadas no Rio de Janeiro e o interesse manifestado pelo Município e pelo Estado de São Paulo, a Presidência da República anunciou um vultoso investimento, da ordem de $\mathrm{R} \$ 4.000 .000 .000,00$ (quatro bilhões de reais), no Plano Integrado de Enfrentamento ao Crack e outras Drogas, que seria readequado para fazer frente à nova realidade e apresentado ao país. Com esse quadro, a Confederação Nacional de Municípios (CNM), num lance de inegável oportunismo político, anunciou que realizara uma enquete entre prefeitos de todo o Brasil que apontava para a "presença" do crack em $98 \%$ de nossas cidades, embora a metodologia adotada no levantamento não encontrasse qualquer respaldo científico. Essa medida de marketing político contribuiu para que a demonização do crack e uma suposta epidemia que estaria se espalhando pelo Brasil tomasse conta do noticiário nacional.

Na sequência imediata, o Ministro da Saúde anunciou a retomada do Plano de Enfrentamento ao Crack e suas adequações. O plano, em linhas gerais, adota os fundamentos que presidem nossa Política Nacional sobre Drogas e a Política de Saúde Mental do Ministério da Saúde, fazendo previsão de ações na área de redução de danos e investimentos para a ampliação e funcionamento da rede SUS - Sistema Único de Saúde, especialmente no que se refere aos chamados CAPS-AD ou Centros de Atenção Psicossocial em Álcool e Drogas, que são os serviços especializados da rede pública, na atenção aos dependentes de álcool e drogas. Há, ainda, especial atenção na ampliação do serviço designado Consultórios de Rua ${ }^{93}$ e também nas Casas de Acolhimento Transitório - CATS ${ }^{95}$. Contudo a Saúde Pública, especialmente setores da área de Saúde

\footnotetext{
${ }^{93}$ Consultórios de rua são dispositivos públicos, componentes da rede de atenção substitutiva em saúde mental, com objetivo principal de estender o cuidado a usuários de álcool e outras drogas em situação de rua, historicamente desassistidos e distantes dos serviços de saúde. As ações de promoção, prevenção e cuidados primários são realizadas in loco, fora de ambientes institucionalizados. As abordagens privilegiam a redução de danos como estratégia de aproximação e cuidado destes usuários. É composto por equipes multidisciplinares, em geral, assistente social, psicólogo, médico, redutor de danos etc., que se utilizam de veículos especialmente adaptados para essa finalidade.

${ }^{94}$ Vide anexo 4.

${ }^{95}$ As Casas de Acolhimento Transitório são resultado de uma experiência desenvolvida em Recife com o nome de Casas do Meio do Caminho ou Casas de Passagem. Consistem em casas de albergamento de usuários da rede de atenção psicossocial em tratamento para transtornos relacionados ao uso de álcool e outras drogas. As Casas de Acolhimento Transitório procuram ampliar os recursos da rede em oferecer a estes usuários cuidados contínuos para populações em estado de vulnerabilidade e riscos. Funcionam como
} 
Mental, recebeu com reservas a previsão de investimentos em leitos destinados à internação e para as chamadas Comunidades Terapêuticas ${ }^{96} 97$.

Tão logo foram anunciadas tais mudanças, os Governos Paulista, estadual e municipal, no dia 03 de janeiro, deflagraram a "Operação Sufoco", intervenção meramente policial-militar com nítida finalidade de higienização da região da "cracolândia". Para tanto, a Polícia Militar ocupou a região como se lá houvesse um grave distúrbio a ser enfrentado manu militari: bombas de efeito moral, disparos de projéteis de borracha e todo um aparato bélico absolutamente desproporcional, que fomentou a violência e outras formas de desrespeitos a direitos fundamentais da pessoa humana.

A intervenção da PM não foi capaz de impedir o tráfico na região e ainda causou um êxodo migratório de usuários em busca da droga em outros locais da cidade. A diáspora provocou o que foi chamado "procissão do crack", e espalhou os usuários por diversos bairros vizinhos.

Representantes do Executivo estadual lançaram a proposta de pagar-lhes passagens

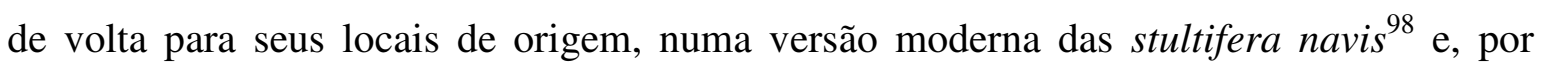
outro lado, o Coordenador de Políticas Públicas em Álcool e Drogas declarou que a finalidade da ação seria a de produzir dor e sofrimento, de modo a forçá-los a buscar o tratamento.

albergues 24 horas que potencializam as ações de saúde mental da rede de atenção, dando maior institucionalidade e continuidade ao cuidado. Sua utilização, na experiência de Recife, é vinculada a um projeto terapêutico que define o tempo de uso do recurso e o objetivo desta utilização. Casas de Acolhimento Transitório podem proporcionar aos usuários de álcool e outras drogas em situação de extrema vulnerabilidade e riscos sociais e de saúde a chance de receber uma intervenção breve ou iniciar um tratamento, protegido das drogas, seja a curto ou a médio prazo, que respeite seu contexto social e familiar, sua capacidade e disponibilidade de adesão, ou seu desejo de interromper ou apenas reduzir seu consumo.

${ }^{96}$ Comunidades Terapêuticas são centros de internação de usuários de álcool e outras drogas, em geral dirigidas por religiosos ou ex-dependentes químicos e que baseiam suas intervenções na espiritualidade, nos princípios de auto-ajuda e nos chamados 12 passos dos Alcoólicos Anônimos (AA).

${ }^{97} \mathrm{Na}$ realidade, há aqui uma disputa ideológica de fundo. A Política Brasileira de Saúde Mental adota, desde o advento da Lei 10.216/01 que a estipulou, os princípios da chamada Reforma Psiquiátrica ou Movimento Antimanicomial que tem como postulado fundamental a desinstitucionalização da pessoa que sofre de agravos mentais, vale dizer, o tratamento deve se dar, preferencialmente, em regime de liberdade, na modalidade ambulatorial, reservando a internação para casos excepcionais e, ainda assim, por períodos de curta duração em instituições não asilares. $\mathrm{O}$ avanço da possibilidade de internações e das comunidades terapêuticas como readequações do Plano original, representaram, nesse contexto, uma perda políticainstitucional, embora o Ministério da Saúde insista que essas instituições deverão integrar a rede de atenção do Sistema Único de Saúde - SUS, cumprindo os requisitos mínimos para funcionamento, conforme regulamentação da ANVISA - Agência Nacional de Vigilância Sanitária.

${ }^{98} \mathrm{Na}$ Idade Média, especialmente na Alemanha e região flamenca, os loucos detidos pelas autoridades eram confiados a barqueiros, eram as "stultifera navis", a Nau dos Loucos. Ver FOUCAULT, Michel. História da loucura na Idade Clássica. São Paulo: Perspectiva, 2000. p. 9. 
Conforme já foi destacado, a Lei 10.216/2001, que rejeita o modelo hospitalocêntrico, consagra, entre outros, "os direitos de ser tratado com humanidade e respeito e no interesse exclusivo de beneficiar sua saúde, visando alcançar sua recuperação pela inserção na família, no trabalho e na comunidade e de ser protegido contra qualquer forma de abuso".

Nesse contexto de arbitrariedades, também merece ser lembrado o Código de Ética Médica $^{99}$ que, logo em seu capítulo primeiro, ao definir seus princípios fundamentais, ressalta:

"VI - O médico guardará absoluto respeito pelo ser humano e atuará sempre em seu benefício. Jamais utilizará seus conhecimentos para causar sofrimento físico ou moral, para o extermínio do ser humano ou para permitir e acobertar tentativa contra sua dignidade e integridade."

O que se tenciona demonstrar, nesse passo, é que pretender a abstinência, pela via da repressão policial, como única alternativa e a internação involuntária indiscriminada, como medida terapêutica, são iniciativas que descortinam uma opção política que aprofunda o apartheid social em que nos acostumamos a viver e que afrontam a dignidade da pessoa humana. A complexidade da questão das drogas - e do crack, em especial exige uma intervenção diversificada e contínua baseada no humanismo e na tolerância, não na segregação e no autoritarismo. O foco deve ser a saúde e a reinserção social.

\subsection{Redução de danos: na busca de um novo paradigma}

Embora existam alguns setores do movimento de redução de danos que se filiem a uma política proibicionista moderada, nos atuais moldes da maioria dos países europeus, tanto que já analisamos alguns programas que funcionam sob este marco legal, os fundamentos ideológicos da redução de danos convergem numa perspectiva antiproibicionista. E isso se explica diante da constatação de que o proibicionismo-punitivo provoca muitos e mais graves danos do que os eventuais agravos à saúde pública, bem jurídico que alega proteger, causados pelas substâncias etiquetadas de ilícitas.

\footnotetext{
${ }^{99}$ Vide anexo 5.
} 
O proibicionismo, não só não soluciona os problemas de saúde pública como, pelo contrário, potencializa o eventual prejuízo, tornando lesão consumada o que era perigo abstrato. Considerando a realidade dos países periféricos, sejam em desenvolvimento ou subdesenvolvidos, os danos sócio-políticos e jurídicos são intensificados e podem ser enumerados da seguinte forma, infelizmente não taxativa:

Sob a ótica da saúde pública: 1) ausência de controle de pureza e adulteração das substâncias consumidas, fatores responsáveis pela maioria das intoxicações agudas; 2) o alto índice de contaminação por $A I D S$, Hepatites e outras doenças infectocontagiosas entre usuários de drogas, em razão do compartilhamento de apetrechos de uso e falta de assepsia nas cenas de uso; 3) aumento das dificuldades na adoção de estratégias de redução de danos, devido ao contexto de clandestinidade imposto pela ilicitude da conduta aliado à resistência das agências de controle penal às abordagens mais compreensivas da conduta: 4) o permanente estado de confronto com sistema penal por parte das pessoas que usam drogas; 5) o incremento da mortalidade, morbidades e co-morbidades decorrentes das práticas de resolução de conflitos numa atividade ilícita e, principalmente, da violência policial na repressão a essas atividades.

Perante as agências de controle penal: 1) a prevalência do aparato policial frente ao sistema judicial; 2) a flexibilização, quando não a supressão, de princípios e garantias constitucionais; 3) a extensão das medidas de exceção criadas para o enfrentamento do "crime organizado" para todos os integrantes da rede: pequenos e médios traficantes, traficantes-dependentes, partícipes, fator determinante para a superpopulação carcerária; 4) desumanização das penas e do sistema penitenciário; 5) superlotação carcerária.

Sob a perspectiva político-socioeconômica podem ser acrescidos os seguintes fatores: 1) incremento do controle das agências penais perante as populações mais desfavorecidas, potencializando o apartamento social; 2) estímulo ao recrutamento de jovens para as atividades criminais e a desagregação familiar; 3 ) incremento do tráfico de armas; 4) fomento às atividades de lavagem de capitais; 5) elevação exponencial dos preços decorrente do incremento do risco a cada aumento de repressão - o recrudescimento do proibicionismo é o principal fator de incremento dos lucros das organizações criminosas; 5) aumento da corrupção, especialmente nas agências de controle penais; 6) estabelecimento de um estado de exceção em extensas faixas urbanas com incremento da violência e dos índices de mortalidade. 
E, como se não bastasse, Maria Lucia $\operatorname{Karam}^{100}$ remata:

"Mas, há outro efeito ainda mais grave. Ao tornar ilegais determinados bens e serviços, como ocorre também em relação ao jogo, o sistema penal funciona como o real criador da criminalidade e da violência. Ao contrário do que se costuma propagar, não são as drogas em si que geram criminalidade e violência, mas é o próprio fato da ilegalidade que produz e insere no mercado empresas criminosas - mais ou menos organizadas - simultaneamente trazendo, além da corrupção, a violência como outro dos subprodutos necessários das atividades econômicas assim desenvolvidas, com isso provocando conseqüências muito mais graves do que eventuais malefícios causados pela natureza daquelas mercadorias tornadas ilegais."

Pois bem, se existe alguma contribuição positiva do proibicionismo essa foi a comprovação de que a criminalização de uma conduta não inibe sua prática, quando ela é socialmente adequada e majoritariamente aceita pela sociedade; por outro lado, também foi possível comprovar que não se pode impor um modelo mundial e uniforme de controle, diante da diversidade das características culturais, econômicas e sociais dos inúmeros países que integram esse concerto de nações.

Por outro lado, deve ser reconhecido que, diante da dimensão global da política de drogas que é condicionada por Convenções Internacionais realizadas no âmbito das Nações Unidas, não há a menor possibilidade de um país implementar, individualmente, uma modificação significativa no sistema proibicionista, que continua em pleno vigor, uma vez que a Comissão sobre Entorpecentes da ONU (CND), em sua última reunião para sua revisão, realizada em Viena em março de 2009, ratificou sua posição originária, sempre com decisivo apoio norte-americano, mantendo-a até o ano de 2019.

\footnotetext{
${ }^{100}$ KARAM, Maria Lúcia. Legislação brasileira sobre drogas: história recente - a criminalização da diferença. In: ACSELRAD, Gilberta (Org.). Avessos do prazer: drogas, Aids e direitos humanos. Rio de Janeiro: Ed. FIOCRUZ, 2000. p. 159-160.
} 


\subsubsection{A descriminalização da Cannabis}

\subsubsection{1. $O$ estado atual do debate: o movimento antiproibicionista e suas propostas}

O reconhecimento desse concerto internacional não pode, todavia, implicar no imobilismo frente às deletérias e perversas consequências da Política Mundial de Drogas, fato reconhecido pela própria Organização das Nações Unidas. Dessa forma, cabe examinar nesse passo, a possibilidade de adoção de medidas intermediárias, entre o proibicionismo e uma nova política de drogas fora do campo penal, dentro do modelo teórico das estratégias de redução de danos e que procurem minimizar o alcance da esfera repressiva, na perspectiva de um direito penal mínimo, e que permitam, por outro lado, minar o imenso poder político e financeiro, paradoxalmente conferido às organizações criminais transnacionais por esse mesmo proibicionismo global.

Uma dessas alternativas, que vem sendo mundialmente debatida na atualidade, é a descriminalização ou a permissão do porte e uso não problemático $^{101}$ de quantias legalmente definidas de algumas drogas, especialmente a cannabis.

A cannabis, ou cânhamo, ganha especial destaque nessa proposta alternativa. Segundo dados da própria Organização das Nações Unidas (ONU), trata-se da droga ilícita mais consumida e mais difundida em todo o mundo, sendo estimado que $80 \%$ (oitenta por cento) dos consumidores mundiais dela se utilizam ${ }^{102}$. Portanto, a descriminalização ou uma distensão com relação à conduta do uso de cannabis implicaria numa significativa alteração na política mundial de drogas diante da escala mundial de seu consumo, além de representar um duro golpe nas máfias que se dedicam ao comércio clandestino dessa substância.

A planta é de origem ancestral. Seu nome científico foi proposto por Lineu, em 1753, mas é popularmente conhecida no Brasil como maconha e nos Estados Unidos da América como marijuana - seus nomes vulgares já nos dão a indicação de um dos motivos

\footnotetext{
${ }^{101}$ O “uso não problemático", previsto em várias legislações europeias, refere-se àquele praticado por maiores de idade, em locais privados, sem causar distúrbios à ordem pública, sem atingir interesse de terceiros e sem o envolvimento de menores, além de excluir as hipóteses de posse de drogas na prisão e em estabelecimentos educacionais, prédios públicos ou locais freqüentados por menores. In: RODRIGUES, B.F L. op. cit., p. 89.

${ }^{102}$ BURGIEMAN, D.R. O fim da guerra: a maconha e a criação de um novo sistema para lidar com as drogas. São Paulo: Leya, 2011. p. 11-12.
} 
que fundamentaram sua proibição ${ }^{103}$. Apesar do estigma negativo que hoje ainda pesa sobre a planta, sua história possui um amplo registro. Proveniente da Ásia Central se expandiu por todo o mundo então conhecido, devido às suas inúmeras propriedades e utilidades. A milenar farmacopeia chinesa, cujos primeiros registros datam de 2.737 a. C., já incluía o cânhamo como remédio. Na Índia é tida como uma planta sagrada desde 2.000 a.C. Heródoto (450 a.C) relata seu uso em saunas citas.

Além de seu uso psicoativo, a cannabis foi largamente utilizada como remédio, fibras para tecidos e papel, óleo combustível até seu uso ser criminalizado nos EUA, em $1937^{104}$. Até essa época, seu extrato era produzido e comercializado por diversas indústrias farmacêuticas, como a Parke-Davis, Squibb, Lilly, dentre outras, e constava da formulação de pelo menos 28 remédios ${ }^{105}$.

Mas a utilização do cânhamo não se restringia a seus múltiplos usos medicinais sua fibra foi utilizada para a fabricação de tecidos, velames e cordoalhas náuticas, devido a sua grande resistência, e seu óleo era largamente usado na iluminação pública. Todavia, a partir do séc. XX, o uso industrial da fibra do cânhamo foi sendo substituído pela indústria de fibras e tecidos sintéticos e, no caso do papel, pela celulose de madeira. Na indústria farmacêutica também foi sendo paulatinamente substituído até sua definitiva proscrição.

Após o fim da Lei Seca, na década de 30, iniciou-se uma intensa campanha oficial, a partir de órgãos policiais capitaneados por Harry Anslinger, então comissário do Federal Bureau of Narcotics e que depois veio a ser durante décadas o "czar antidrogas" norteamericano, associando a cannabis a imigrantes mexicanos e atribuindo-lhe propriedades indutoras de crimes e violência, conseguindo sensibilizar o Congresso e, finalmente, criminalizar o seu uso através da Marijuana Tax Law, promulgada em 1937. Após a segunda guerra mundial, os Estados Unidos emergem como a maior potência do mundo ocidental e sua hegemonia no concerto internacional possibilitou a mundialização da proibição da cannabis, através das Convenções da ONU ${ }^{106}$.

A história no Brasil não foi muito diferente, embora aqui a cannabis sempre tenha sido associada aos afrodescendentes uma vez que há indícios de que foram os escravos

\footnotetext{
${ }^{103}$ No Brasil, até os anos 60 , a maconha era sempre relacionada, de forma discriminatória, à população afrodescendente e, nos EUA, aos imigrantes latinos, especialmente os mexicanos. In: CARNEIRO, Henrique. Pequena Enciclopédia da história das drogas e bebidas: histórias e curiosidades sobre as mais variadas drogas e bebidas. Rio de Janeiro: Elsevier, 2005. p. 71-76.

${ }^{104}$ Marijuana Tax Law.

${ }^{105}$ CARNEIRO, Henrique. op. cit., p. 74.

${ }^{106}$ BURGIEMAN, D.R.op. cit., p. 63-66.
} 
africanos que introduziram, primeiramente, a planta no país. Não obstante isso, há registros que atestam o forte interesse da Coroa Portuguesa na cultura do cânhamo, devido a seu alto valor econômico e da utilização de sua fibra na fabricação do velame e da cordoalha utilizada nas caravelas, sendo certo que, em 1799, o então vice-rei do Brasil, marquês do Lavradio, determinou seu cultivo em extensas regiões de Santa Catarina e Rio Grande do Sul. $^{107}$

De qualquer sorte, a depreciação do grande valor utilitário que era até então atribuído à cannabis teve nítida conotação étnica e é certo que, a partir do início do séc. XX, cientistas brasileiros como Rodrigues Dória e Francisco Iglesias, passaram a difundir suas teses que se fundavam no conceito de eugenia, que ganhava prestígio acadêmico na época, associando a cannabis à população de origem africana e atribuindo-lhe efeitos como degeneração mental e moral, vício, psicose e crime que também diziam ser típicos daqueles indivíduos. O teor discriminatório que fundamentava as teorias desses cientistas sobre os efeitos do uso da maconha, que Rodrigues Dória chamou de 'a vingança dos vencidos', pode ser conferido pela leitura de trecho de sua comunicação ao Segundo Congresso Científico Pan-americano, realizado em Washington em 1915:

"A raça preta, selvagem e ignorante, resistente, mas intemperante, se em determinadas circunstâncias prestou grandes serviços aos brancos, seus irmãos mais adiantados em civilização, dando-lhes, pelo seu trabalho corporal, fortuna e comodidades, estragando o robusto organismo no vício de fumar a erva maravilhosa, que, nos êxtases fantásticos, lhe faria rever talvez as areais ardentes e os desertos sem fim de sua adorada e saudosa pátria, inoculou também o mal nos que o afastaram da terra querida, the roubaram a liberdade preciosa, e lhe sugaram a seiva reconstrutiva". (Dória, 1915; 37) ${ }^{108}$

Esse discurso, impregnado de categorias racistas, assemelha-se ao utilizado nos Estados Unidos da América contra os imigrantes mexicanos e serviu para demonizar, a partir de então, o consumo da maconha no imaginário de gerações de brasileiros, desqualificando suas inúmeras propriedades e utilizações legítimas e criando o clima propício para o advento de sua proibição, ocorrida aqui também durante os anos 30 .

Daí até os anos sessenta, a cannabis seguiu proscrita e seu uso criminalizado; era tão malvista quanto desconhecida e o hábito de seu uso era tido como restrito aos negros,

\footnotetext{
${ }^{107}$ CARNEIRO, Henrique. op. cit., p.73.

${ }^{108}$ VIDAL, Sérgio. Da diamba à maconha: usos e abusos da Cannabis sativa e da sua proibição no Brasil. Disponível em: <http://www.koinonia.org.br/bdv/detalhes.asp?cod_artigo=304>.
} 
em nosso país, e mexicanos nos EUA, mas de qualquer modo pobres e marginalizados. Com o advento da contracultura, tanto nos EUA quanto no Brasil, essa situação muda radicalmente uma vez que o uso da cannabis foi assumido como símbolo de contestação ao sistema pelos integrantes desse movimento, especialmente aqueles conhecidos como "hippies". Após o verão de 67, que nos Estados Unidos ficou conhecido como "verão do amor", o uso da marijuana foi largamente disseminado pela juventude, branca e de classe média, norteamericana ${ }^{109}$. No Brasil, apesar da Ditadura Militar em plena vigência, o mesmo fenômeno passou a ser notado, a partir da década de 70.

Em contrapartida, embora possa parecer paradoxal, talvez pela familiarização que se impôs, é também a partir dessa época que o uso da cannabis passa a, paulatinamente, ser visto com mais tolerância. Na década de 80 , na transição para o regime democrático, o debate sobre a revisão da política de drogas ganha novo impulso. A chamada imprensa alternativa que incluía publicações como Repórter, O Inimigo do Rei, Lampião, Movimento e Coo-Jornal passam a assumir posição favorável à descriminalização da cannabis e a publicar uma série de reportagens nessa linha.

A partir de 1982, estudantes, artistas e intelectuais começam a articular a criação de um movimento organizado pela descriminalização e uma série de debates foi promovida no Rio de Janeiro e São Paulo. Em outubro de 1986, nas escadarias do Teatro Municipal de São Paulo, foi realizado o primeiro ato público em favor da descriminalização da maconha e cerca de 50 pessoas, dentre eles, estudantes, a maioria da Faculdade de Direito da Universidade de São Paulo, sindicalistas ligados ao Sindicato dos Bancários e militantes da causa foram presas, em flagrante pelo delito de contribuição, induzimento ou incentivo ao uso de drogas, previsto na legislação então vigente. Por ironia do destino, o flagrante foi presidido pelo Delegado Paulo Sérgio Fleury, filho do conhecido e temido Delegado Sérgio Fleury, que, após longa negociação com os advogados presentes, acabou por liberar os manifestantes por entender que o ato era lícito num Estado Democrático de Direito. O único detido que teve seu flagrante confirmado foi um incauto escriturário que passava pelo local e aderiu à manifestação por se solidarizar com a causa. Ocorre que, por não ter participado das reuniões preparatórias do ato, desconhecia a orientação dada pelos advogados e trazia consigo um "baseado"110 111.

\footnotetext{
${ }^{109}$ BURGIEMAN, D.R. op. cit., p. 70. Confira ainda: VIDAL, Sérgio. op. cit.

${ }^{110}$ Nome popular do cigarro de cannabis.

${ }^{111}$ LABATE, Beatriz Caiuby et al. (Orgs.). Drogas e cultura: novas perspectivas. Salvador: EDUFBA, 2008. p. 120.
} 
Ainda nos anos 80, o debate sobre a descriminalização atinge o discurso político e ganha defensores que o assumem como ponto programático e tema de campanha. Em São Paulo tivemos o engajamento de João Batista Breda, Henrique Carneiro e Catarina Koltai, no Rio de Janeiro, Lizt Vieira e, na Bahia, o músico Galvão, que usava como tema de campanha a música de sua autoria. "Você pode fumar baseado".

Na década de 1990, no campo da militância político-social os ânimos se arrefeceram, devendo ser lembrado, contudo, o ativismo dos músicos Gabriel Pensador e os integrantes do grupo musical Planet Hemp, que ficaram uma semana presos em razão das letras de suas músicas pró-legalização, além de, no campo político, as iniciativas de Fernando Gabeira. Todavia e não menos importante, foi nessa década que o movimento de redução de danos se estrutura e ganha seu espaço político-institucional.

Nos EUA, em 1997, uma iniciativa acadêmica pioneira mereceu destaque internacional. Lynn Zimmer e John P. Morgan, ela socióloga e ele médico farmacologista, ambos professores e pesquisadores da prestigiada City University of New York realizaram a mais completa revisão bibliográfica sobre a cannabis e que resultou na publicação do livro recentemente publicado no Brasil sob o título "Maconha: mitos e fatos - uma revisão das provas científicas.

Os autores introduzem seu trabalho lembrando que, em quase cem anos de proibicionismo, várias comissões independentes foram criadas por seus respectivos governos para investigar os efeitos da cannabis $^{112}$, todas elas chegando a conclusões semelhantes quanto a baixa toxicidade da substância e desnecessidade de criminalização da conduta. Talvez, dentre todas elas, a mais emblemática seja a Comissão Nacional sobre Abuso de Maconha e de Drogas (National Comission on Marihuana and Drug Abuse), que foi criada em 1971, pelo então Presidente Richard Nixon que pretendia, com base nesse relatório, subsidiar cientificamente sua promessa de campanha de empreender uma guerra contra as drogas. No seu relatório final os pesquisadores afirmaram ter "opinião unânime que o consumo de maconha não é um problema tão grave a ponto de os indivíduos que a

\footnotetext{
${ }^{112}$ Os principais relatórios produzidos sobre o assunto são: Indian Hemp Drug Comission (1894); The New York Academy of Medicine (1944); President Kennedy.s White House Comission on Narcotics and Drug Abuse (1962); Relatório Wotton (1968); Relatório da Comissão do Governo do Canadá (1970); Relatório da Comissãodo Governo da Holanda (1972); President Nixon.s National Comission onMarijuana and Drug Abuse (1972); The National Academy of Sciences Substance Abuse Report (1982); The United Nation's World Health Organization Report (1999); National Institute of Medicine Report (1999).
} 
fumam ou carregam para uso próprio terem de ser processados"; o tiro saiu pela culatra e Nixon teve que se lançar na guerra sem apoio da comunidade científica ${ }^{113}$.

Após empreenderem exaustiva revisão e análise, os autores encerram sua obra com a seguinte conclusão:

"Mais de 70 milhões de americanos - 35 por cento daqueles com mais de 26 anos de idade - já usaram maconha; um quinto ainda fuma maconha, ao menos ocasionalmente. A maconha é a droga ilícita mais amplamente usada nos Estados Unidos. Na verdade, é a única droga ilícita usada de forma ampla. Seu uso ocorre em todas as regiões do país, entre pessoas de todas as classes sociais, etnias, profissões, religiões e conviç̧ões políticas. Em erto sentido, o uso de maconha já faz parte da cultura 'normal' da população. O que torna a maconha elemento de desvio é a sua contínua criminalização."

No início dos anos 2000, as chamadas redes sociais viabilizaram, através da comunicação virtual, um novo espaço de debates públicos sobre o tema inclusive possibilitando o estabelecimento de contatos com movimentos internacionais da mesma natureza. Essa articulação deu causa à organização, no Brasil, de passeatas em favor da descriminalização da maconha, seguindo o calendário internacional. Além disso, representou um marco no movimento porque promoveu a estréia, no debate político, de um ator fundamental que estava, até o momento, ou alijado ou intimidado pela própria criminalização de exercer seus direitos políticos. Entra em cena, a partir de então, os cidadãos que usam drogas.

Esse ativismo cibernético acabou possibilitando o surgimento de várias organizações não governamentais e coletivos antiproibicionistas ao longo desses últimos anos destacando-se os já tradicionais Princípio Ativo (Porto Alegre), Growroom (nacional), Hempadão (Rio de Janeiro), Canabis Ativa (Natal), Ananda (Salvador), a ONG Psicotropicus (Rio de Janeiro), Filipeta da Massa (Recife) e o coletivo DAR Desentorpecendo a Razão (São Paulo).

Em 2001, pela primeira vez, um semanário de distribuição nacional dá destaque de capa ao tema e, num lance de ousadia para a época, entrevista várias pessoas que assumem o uso da maconha e que são apresentadas na capa da revista sob a manchete "Eu fumo". A repercussão foi ampla e imediata e o debate permaneceu na pauta por semanas.

\footnotetext{
${ }^{113}$ ZIMMER, L.; MORGAN, J. P. Maconha: mitos e fatos - uma revisão das provas científicas. Rio de Janeiro: Psicotropicus, 2010. p. 16-18.
} 
Em 2007, com núcleos locais já articulados, algumas cidades organizaram um calendário de manifestações, sob o nome "Marcha da Maconha". No ano seguinte, houve uma tentativa de realizar a Marcha da Maconha em doze capitais, simultaneamente, contudo, decisões judiciais proibiram a manifestação, na maioria delas sob a alegação de apologia ao uso de drogas e, até mesmo, formação de quadrilha.

O movimento tornou-se, desde então, nacionalmente conhecido como a Marcha da Maconha e passou a ser realizado, a partir de então, sempre em meio a percalços judiciais, especialmente na cidade de São Paulo.

Em junho de 2011, entretanto, o Supremo Tribunal Federal decidiu, por unanimidade, pela legitimidade da manifestação, considerando que sua proibição é uma ameaça à liberdade de expressão.

No campo acadêmico, o debate também avança, notadamente após as recentes descobertas da neurociência sobre receptores do sistema nervoso e até um sistema endocanabinol, além das inúmeras pesquisas que têm comprovado as propriedades terapêuticas da cannabis.

Em 2004, ocorreu o Seminário Cannabis Sativa L. e Substâncias Canabinóides em Medicina, organizado pela Secretaria Nacional Antidrogas - SENAD e pelo Centro Brasileiro de Informações sobre Drogas Psicotrópicas - CEBRID, que reuniu pesquisadores, autoridades políticas e científicas do país e alguns convidados estrangeiros de países como Holanda, E.U.A. e Canadá. Foi apresentado um panorama das pesquisas e experiências atuais sobre as potencialidades da cannabis e dos seus princípios ativos, enquanto medicamento, e as experiências existentes de prescrição e distribuição dos seus derivados para uso médico em diferentes países.

Renato Malcher Lopes ${ }^{114}$, um dos mais destacados neurocientistas brasileiro na atualidade, assim resume a questão do uso terapêutico:

"Ingeridos ou inalados por meio de vaporizadores (que não queimam a planta), os princípios ativos da maconha podem levar ao alívio efetivo e imediato de náuseas e falta de apetite em pacientes sob tratamento quimioterápico, de espasmos musculares da esclerose múltipla e de diversas formas severas de dor-muitas vezes resistentes aos demais analgésicos.

\footnotetext{
${ }^{114}$ LOPES, Renato Malcher. Maconha, uma planta medicinal. Disponível em: <http://sergyovitro.blogspot.com/2011/05/maconha-uma-planta-medicinal-renato.html>.
} 
Pesquisas recentes indicam também o potencial da maconha para o tratamento de doença de Huntington, do mal de Parkinson, de Alzheimer e de algumas formas de epilepsia e câncer. A redução da ansiedade e os efeitos positivos sobre o estado emocional são valiosas vantagens adicionais, que elevam sobremaneira a qualidade de vida dessas pessoas $e$, por conseguinte, seus prognósticos.

A maconha não serve para todos: há contraindicações e grupos de risco, como gestantes, jovens em crescimento e pessoas com tendência à esquizofrenia. Em menos de $10 \%$ das pessoas o uso descontrolado pode gerar dependência psicológica reversível. Mas, ponderados riscos e benefícios, para a grande maioria das pessoas, a maconha continua a ser remédio seguro.

A biotecnologia brasileira tem todas as condições para desenvolver variedades com diferentes proporções de princípios ativos, reduzindo efeitos colaterais e aumentando a eficácia das plantas (ou de seus extratos) para cada caso."

Finalmente, no campo político social, o debate antiproibicionista também avançou e merece destaque, no plano nacional, a tomada de posição por parte do Instituto Brasileiro de Ciências Criminais - IBCCrim, assumindo institucionalmente a necessidade de revisão integral do modelo proibicionista e a adoção da legalização controlada como política criminal para a produção, distribuição, comércio e uso pessoal de drogas.

No plano internacional, repercutiram fortemente as posições assumidas pelo expresidente brasileiro Fernando Henrique Cardoso que, juntamente com o ex-presidente da Colômbia César Gavíria Trujillo, o ex-presidente mexicano Ernesto Zedillo e outras personalidades de destaque, artistas, intelectuais, juristas e empresários latino-americanos, criaram a Comissão Latinoamericana para as Drogas e a Democracia e passaram a capitanear uma campanha mundial pela revisão da política de drogas.

Essa iniciativa foi de tal forma exitosa e bem recebida que evoluiu para a criação da Comissão Global de Políticas de Drogas. Trata-se de um grupo de dignitários e personalidades de destaque mundial, cujo objetivo é promover a discussão, em nível internacional, sobre os danos causados pelas drogas e os meios para sua efetiva redução, com amparo em bases científicas. Assoma em importância esse empreendimento quando verificamos que seus membros são exatamente os mesmos dignitários que implantaram, em escala mundial, a política conhecida como "war on drugs" e que, agora, reconhecem seu fracasso e reivindicam sua revisão. 
Compreendendo que a associação entre o comércio de drogas, a violência e a corrupção são uma ameaça à democracia na América Latina, a Comissão reavaliou as políticas predominantes de "guerra às drogas" e iniciou um debate público a respeito da questão que tende a ser permeada pelo medo e pela falta de informação. ${ }^{115}$

Os objetivos da Comissão são, basicamente, os seguintes: (a) revisar o fundamento, a efetividade e as consequências da questão da "guerra às drogas", (b) avaliar os riscos e os benefícios das diversas respostas dos países ao problema das drogas e (c) desenvolver recomendações praticáveis e fundadas para uma reforma legal construtiva da política de drogas. $^{116}$

Para realçar a importância da Comissão, basta apenas citar alguns de seus integrantes, respeitados internacionalmente pela experiência acadêmica e profissional: Asma Jahangir, ativista pelos direitos humanos e ex-Relatora Especial das Nações Unidas sobre Execuções Extrajudiciais, Sumárias ou Arbitrárias; Javier Solana, ex-Alto Representante da União Européia para Política Exterior e Segurança Comum; Kofi Annan, ex-Secretario Geral das Nações Unidas; Mario Vargas Llosa, escritor e intelectual; John Whitehead, banqueiro e presidente da Fundação World Trade Center Memorial; Marion Caspers-Merk, ex-Secretária de Estado do Ministério Federal da Saúde da Alemanha.

Dando sequência aos seus objetivos, a Comissão Global lançou, em 2011, seu primeiro relatório que inicia com a constatação de algo que já é notório: "a guerra às drogas fracassou, com consequências devastadoras para os indivíduos e sociedades ao redor do mundo". Afirma, ainda, que "os imensos recursos destinados à criminalização e às medidas repressivas orientadas aos produtores, traficantes e consumidores de drogas ilegais fracassaram eficazmente em reduzir a oferta ou o consumo".

E mais, a Comissão elaborou alguns princípios e recomendações, encaminhados à Organização das Nações Unidas, como alternativas à atual guerra às drogas. São basicamente oito as recomendações:

1. "Acabar com a criminalização, a marginalização e a estigmatização das pessoas que usam drogas mas que não causam nenhum dano a outros;

\footnotetext{
${ }^{115}$ Informações retiradas da página oficial da COMISSÃO GLOBAL DE POLÍTICAS DE DROGAS. Disponível em: <http://www.globalcommissionondrugs.org/>.

${ }^{116}$ Id. Ibid.
} 
2. Incentivar os governos a tentarem modelos de regulação legal das drogas a fim de eliminar o poder do crime organizado e para salvaguardar a saúde e a segurança dos seus cidadãos;

3. Oferecer serviços de saúde e tratamento aos que deles necessitem, de acordo com o caso concreto, inclusive com a implementação de medidas de redução de danos, como o oferecimentos de seringas descartáveis;

4. Respeitar os direitos humanos das pessoas que usam drogas, abolindo as práticas abusivas praticadas em nome do tratamento, como o trabalho forçado, a internação forçada ou abusos físicos e psicológicos;

5. Focar as ações repressivas nas organizações criminosas violentas, mas fazê-lo de maneira a eliminar seu poder e seu alcance, enquanto dáse prioridade à redução da violência e da intimidação;

6. Investir em atividades que possam prevenir, em primeiro lugar, que os mais jovens usem drogas e prevenir que aqueles que já usem possam desenvolver problemas mais sérios;

7. Começar a transformação do regime mundial de proibição das drogas, repensando as políticas e estratégias movidas apenas por conveniência e ideologia política;

8. Por fim, romper o tabu sobre o debate e a reforma. Agora é tempo de mudar."

Culminando esse processo, agora já em 2012, às vésperas do conclave internacional conhecido como Cúpula das Américas, o presidente da Colômbia, Juan Manuel Santos, anfitrião do encontro, se declarou favorável à legalização da maconha e da cocaína como alternativas para erradicar a violência do narcotráfico. Logo a seguir, os presidentes da Guatemala e El Salvador, Otto Perez e Mauricio Funes conclamaram seus pares a iniciar o debate sobre a regulação do uso e comércio de drogas nesse encontro, no que foram secundados pela presidenta da Costa Rica, Laura Chinchilla e do México, Felipe Calderón, que embora não assumindo nenhuma posição em suas declarações concordaram ser necessário promover o debate a nível internacional ${ }^{117}$. A posição do presidente da Bolívia, Evo Morales, já é internacionalmente conhecida, até mesmo pela sua ascensão política a partir do movimento sindical cocalero.

Todas essas vertentes da mobilização política mundial visando uma revisão ou ao menos uma distensão na política de "guerra às drogas" convergem para pressionar a Organização das Nações Unidas nesse mesmo rumo e permitem a realização de um prognóstico positivo no sentido de uma modificação de rumos, ao menos quanto a cannabis.

\footnotetext{
${ }^{117}$ AMÉRICA Latina quiere hablar de drogas. El Pais, 23.02.2012. Internacional. Disponível em: <http://internacional.elpais.com/internacional/2012/02/23/actualidad>. Acesso em: 23 fev. 2012.
} 
E tanto isso é verdade que, de fato, essas mudanças já vêm ocorrendo em vários países do mundo. Além da Holanda, que sempre foi o paradigma de uma política alternativa, com sua flexibilização para com o uso privado de cannabis e a destinação de locais especialmente destinados para essa finalidade (coffe shops), temos hoje diversos países europeus, dentre eles a Espanha e Itália que descriminalizaram o uso privado de drogas, e Portugal que hoje se tornou a referência mundial em política alternativa de drogas, uma vez que é o único país que descriminalizou totalmente essa conduta, realizando seu controle pela via administrativa ${ }^{118}$.

Nas Américas o Canadá foi sempre uma referência em políticas mais liberais com relação às drogas e mesmo os Estados Unidos passam hoje por intensa revisão, posto que seu sistema federativo permite a adoção de políticas estaduais diferenciadas e, capitaneados pela Califórnia, dezesseis estados americanos e mais o Distrito de Columbia, onde está sediada a capital federal, já aprovaram a regulamentação do uso terapêutico da cannabis, que pode ser legalmente adquirida em dispensários ${ }^{119}$ especialmente dedicados a esse comércio.

Na América Latina, a Argentina e a Colômbia descriminalizaram o uso privado, a partir de decisões de suas Cortes Constitucionais que reconheceram a inconstitucionalidade da criminalização da conduta ${ }^{120}$ e o Uruguai admite o porte e uso privado de pequena quantidade de cannabis.

A questão que se coloca, atualmente, para os países que já adotaram políticas alternativas com relação ao consumo de psicotrópicos é a de como dar sustentabilidade ao sistema. O problema que se apresenta decorre da ambiquidade do sistema. Nenhum deles descriminalizou a produção, distribuição e o comércio de cannabis. Dessa forma, a pessoa tem o direito ao consumo privado de cannabis mas não tem onde adquirir, de forma lícita, o produto. Várias alternativas estão sendo discutidas, na Califórnia por exemplo, há uma

\footnotetext{
${ }^{118}$ A política de drogas portuguesa será analisada no próximo tópico.

${ }^{119}$ Boticas fitoterápicas especializadas em cannabis, seus derivados e produtos extraídos a partir da planta.

${ }^{120}$ A Suprema Corte Argentina declarou, em 2010, a inconstitucionalidade da incriminação do porte de drogas para uso próprio em razão da impossibilidade da intervenção estatal no âmbito privado dos cidadãos. A Corte Constitucional da Colômbia ratificou, em 2009, o mesmo entendimento que já havia adotado desde 1994, confirmando a inconstitucionalidade de dispositivo idêntico. No Brasil, a $6^{\text {a }}$ Câmara do $3^{\circ}$ Grupo da Secção Criminal do Tribunal de Justiça de São Paulo declarou a inconstitucionalidade do artigo 28 da Lei de Drogas, na Apelação Criminal, n 01113563.3/0-0000-000, da Comarca de São José do Rio Pardo, em 31 de março de 2008. O Supremo Tribunal Federal admitiu, no final de 2011, a repercussão geral no Recurso Especial n. 635659 proveniente da Comarca de Diadema, onde a Defensoria Pública argüiu a inconstitucionalidade do artigo 28 da Lei 13.343 por afronta à intimidade e à vida privada, além da falta de lesividade e alteridade da conduta.
} 
permissão para que cada usuário medicinal possa produzir até 25 pés de cannabis para seu consumo pessoal, daí foi criado um sistema de cooperativas que reúne diversos desses consumidores e organizam a produção coletiva, em geral indoor ${ }^{121}$. Além disso, é regulamentada a produção e distribuição para a venda nos dispensários, que também só comercializa o produto para clientes associados ao coletivo e que tenham indicação médica para o uso $^{122}$.

Mas a alternativa que mais vem ganhando destaque nesse novo debate que se instala é a espanhola, que estabeleceu um sistema, também cooperativo, denominado Clubes Sociais de Cannabis (CSC). O modelo foi originalmente apresentado, como proposta de redução de danos, pela Coligação Européia por Políticas de Drogas Justas e Eficazes (ENCOD) e hoje já foi implantado na Espanha, na Bélgica e na Suíça. A proposta se baseia na formação de associações de consumidores que teriam como princípios: 1) não ter fins comerciais nem buscar obtenção de lucro; 2) só aceitar como associados, pessoas maiores de 18 anos; 3) não fazer qualquer tipo de publicidade; 4) notificar, constantemente, a quantidade de plantas cultivadas e de flores colhidas e distribuídas; 5) não realizar qualquer tipo de comércio ou de distribuição gratuita a pessoas não associadas; e 6) manter um constante diálogo com os órgãos de Saúde Pública ${ }^{123124}$.

Resta finalmente, numa prognose, verificar se um modelo semelhante poderia ser adotado no Brasil. Realizando uma interpretação sistemático teleológica, tendo em conta os princípios que norteiam a nova lei e as finalidades da Política Nacional sobre Drogas, com relação ao delito de porte para uso próprio capitulado no seu artigo 28 teremos inicialmente que a nova base principiológica adota estabelece que: "o respeito aos direitos fundamentais da pessoa humana, especialmente quanto à sua autonomia e à sua liberdade”, conforme a dicção do artigo $4^{\circ}$, inciso I; "o respeito à diversidade e às especificidades populacionais existentes", nos termos do inciso II do mesmo dispositivo legal; além da necessidade do "fortalecimento da autonomia e da responsabilidade individual em relação ao uso indevido de drogas", conforme o disposto no seu artigo 19, inciso III.

\footnotetext{
${ }^{121}$ O plantio é realizado no interior de estufas e galpões, ou mesmo dentro de casa.

${ }^{122}$ BURGIEMAN, D.R. op. cit., p. 154.

${ }^{123}$ VIDAL, Sérgio. A regulamentação do cultivo da maconha para consumo próprio: uma proposta de redução de danos. In: NERY FILHO, Antonio et al. (Orgs.). Toxicomanias: incidências clínicas e socioantropológicas. Salvador: EDUFBA: CETAD, 2009. p. 87-88.

${ }^{124}$ Para saber mais sobre a proposta: CANNABIS SOCIAL CLUBS, DRAFT TO THE PROJECT. Disponível em: <www.encod.org/info/test>.
} 
Pois bem, ao punir o delito de porte para uso pessoal, isolada e unicamente, com pena restritiva de direitos o legislador inaugura uma nova modalidade de delitos em nosso sistema penal, vale dizer, os delitos de mínimo potencial ofensivo ${ }^{125}$. Seguindo nessa linha de pensamento verifica-se de plano que o delito de "uso de drogas" é, nos termos da nova lei, absolutamente incompatível com a privação de liberdade do eventual infrator.

Tanto assim que a lei veda em seu artigo 48, $\S 2^{\circ}$ a imposição de prisão em flagrante ao autor da conduta prevista no artigo 28, devendo este ser encaminhado imediatamente ao juízo competente ou assumir o compromisso de a ele comparecer. Tal compromisso poderá ser tomado pela própria autoridade policial, sempre vedada a detenção do autor do fato, conforme estabelece o $\$ 3^{\circ}$ do artigo 48 da nova lei de drogas. Dessa forma, ao contrário do que tem sido afirmado pela maioria da doutrina, não será possível, realmente, a prisão em flagrante do autor da conduta tipificada.

Diante da impossibilidade de prisão em flagrante está absolutamente vedado o ingresso em casa particular para a constatação ou apreensão de drogas ilícitas que estejam sendo utilizadas para consumo próprio sem mandado judicial, uma vez que a norma constitucional excepciona apenas aquela hipótese, conforme prevê o inciso XI do artigo $5^{\circ}$ da Constituição Federal.

Numa análise sistemática da lei essa impossibilidade fica realçada quando se verifica que não foi criminalizada a conduta de quem utiliza local ou bem de sua propriedade ou posse, por qualquer título, para o uso de substâncias psicotrópicas, conduta que era anteriormente equiparada ao tráfico conforme o inciso II do $\S 2^{\circ}$ do artigo 12 da Lei ${ }^{\circ} 6368 / 76$.

Com essa nova conformação o legislador, na realidade, reconfigurou o âmbito de interesse e atuação legítima do Estado. Caso a conduta não tenha relevância e permaneça no plano da intimidade do cidadão que faça uso da droga, fora do espaço público, não será permitida a intervenção desmotivada do Estado que nesse limite somente poderá ingressar munido de autorização judicial.

Ao delimitar o interesse estatal o legislador deu nova solução ao conflito de direitos constitucionalmente assegurados. A conduta está criminalizada, contudo, se praticada no espaço público terá potencialidade de expansão e sujeitará o infrator à pronta e imediata

\footnotetext{
${ }^{125}$ Também nesse sentido ver: MAGNO, Levy Emanuel. In: GUIMARÃES, Marcello Ovídio Lopes (Coord.). Nova lei antidrogas comentada. São Paulo: Quartier Latin, 2007. p. 120.
} 
intervenção estatal, contudo, se praticada no recesso de sua privacidade, no interior de sua residência, por exemplo, o infrator, embora cometendo um ilícito penal, somente estará passível da intervenção estatal se a autoridade pública se apresentar munido de mandado que lhe franqueie o acesso na residência da pessoa averiguada.

A mesma orientação se aplica a conduta de plantio para uso pessoal que, nos termos do $\S 1^{\circ}$ do artigo 28 , está equipada à conduta de porte para uso próprio. Remarque-se, que essa alternativa de suprimento autônomo por parte da pessoa que dela se utiliza retira uma fonte fundamental de recursos da atividade comercial ilícita e evita o estabelecimento de vínculos da pessoa que usa drogas com as organizações criminosas que se dedicam ao tráfico.

Dessa forma é possível projetar, com a necessidade de poucas alterações legais, quiçá apenas regulamentação de natureza administrativa, para a implementação de clubes de canabismo no Brasil. Caso a autorização para o uso seja restrito a determinados locais e certos grupos de pessoas, a conduta estará contida naquele âmbito específico e será passível de um melhor controle criminal, social e médico-sanitário.

Estratégias dessa natureza, que visam à prevenção de riscos e a redução de danos são condutas adotadas comumente como controles informais e, em nossa história, tivemos experiências semelhantes como os clubes de diambistas do Maranhão, conforme os relatos de estudiosos da época ${ }^{126}$. Por outro lado, condutas que envolvem aspectos morais e criminalizadas com maior rigor - como o ato obsceno, tipificado no artigo 233 do Código Penal e sancionado com pena de detenção de três meses a um ano - são também de tipificação restrita ao espaço público e há tolerância com sua prática privada e mesmo permissão e destinação de locais especialmente adequados à atividade do naturismo, geridos por associações ou clubes de pessoas cultoras dessa cultura.

\footnotetext{
${ }^{126}$ IGLÉSIAS, Francisco Assis. Sobre o vício da diamba. In: BRASIL. Serviço Nacional de Educação Sanitária. Maconha: coletânea de trabalhos brasileiros. Rio de Janeiro: Ministério da Saúde, 1958. p. 18-19.
} 


\subsubsection{A descriminalização do uso de drogas}

\subsubsection{O modelo português}

Há pouco mais de dez anos ${ }^{127}$, Portugal, um país reconhecidamente conservador, com forte influência religiosa e que teve sua história recente marcada por uma ditadura, adotou uma política sobre drogas ousada e pioneira, que tem como marco legal a descriminalização da posse de pequena quantidade de droga ${ }^{128}$ para consumo pessoal, inclusive aquelas classificadas como drogas "pesadas", como a cocaína e a heroína.

A estratégia adotada foi a de retirar a infração do âmbito penal e transformá-la num ilícito de mera ordenação social, ou contra- ordenações, que se situam no campo do Direito Administrativo ou, mais precisamente, administrativo-penal ${ }^{129}$. Portanto, em vez de tentar diminuir o uso através da punição dos consumidores, as novas medidas mantêm as drogas ilegais, mas já não tratam o consumo como um crime. Isso viabilizou a implantação de todo um conjunto de novas estratégias com abordagens mais tolerantes e que possibilitam o estabelecimento de vínculos com os usuários dessas substâncias, sem que fosse necessário abdicar do controle sobre sua utilização, todavia realizando-o através de institutos não-penais e, com isso, sem afrontar as Convenções Internacionais das quais Portugal também é signatário.

Esse reenquadramento legal permitiu a implantação de um vasto leque de medidas em áreas como a prevenção e educação, o tratamento e assistência na reinserção social das pessoas que usam drogas, sem estigmatizá-las pela criminalização de sua conduta e, com isso, sem amedrontá-las na eventual busca de auxílio. Por outro lado, os agentes, públicos e

\footnotetext{
${ }^{127}$ A nova política foi implantada pela Lei no 30/2000 que entrou em vigor em 01/07/2001.

${ }^{128} \mathrm{~A}$ quantidade estabelecida pela lei foi indicada como sendo suficiente para o consumo de uma pessoa por um período de 10 dias, ou seja: cannabis folha, 25 gramas; haxixe, 5 gramas; cocaína, 2 gramas; heroína, 1 grama; LSD ou ecstasy, 10 comprimidos. Atualmente, prevalece o entendimento de que essas quantidades são indicativas, devendo ser cotejada com outras informações indiciárias de outra modalidade de conduta, como por exemplo, local da apreensão (escolas, clubes noturnos etc.) forma de acondicionamento etc. Vide: Conferir nesse sentido: Domostawski, Artur. Política da droga em Portugal. Os benefícios da descriminalização do consumo de drogas. Global Drug Policy Program/Open Society Foundations, 2011, págs. 16 e 27. O tráfico de drogas continua recebendo um tratamento penal severo com penas variando numa escala de 1 (um) a 12 (doze) anos, de acordo com o tipo de substância. Essas penas poderão sofrer acréscimos de até um quarto na ocorrência de circunstâncias agravantes. É prevista, ainda, a figura do traficante-consumidor, que recebe tratamento penal mais brando. Vide: RODRIGUES, Luciana Boiteux de Figueiredo. op. cit., p. 130.

${ }^{129}$ RODRIGUES, Luciana Boiteux de Figueiredo. op. cit., p. 128.
} 
privados, integrantes dos serviços de atenção que trabalham nessa área deixaram de temer pela segurança jurídica das ações que praticam uma vez que, sob o regime anterior, lhes era frequentemente imputado o delito de auxílio ao uso de drogas.

O novo modelo criou o ambiente jurídico-político adequado para que a política de drogas pudesse se concentrar nas ações de prevenção e educação, redução de danos, ampliação e melhoria dos programas de tratamento e em atividades que ajudassem grupos de risco ou consumidores de drogas a manter ou restaurar as suas relações famíliares, laborais e sociais.

$\mathrm{Na}$ base dessa nova filosofia de ação estava o reconhecimento da pessoa que usa drogas como um interlocutor qualificado para determinar sua própria conduta, um sujeito de direitos e não apenas um alvo da tutela ou da sanção do estado. Isso implica no reconhecimento da diversidade das razões etiológicas do uso de drogas: problemas pessoais, fatores sociais ou por recreação ou prazer e, portanto, no tratamento diferenciado que devem receber essas pessoas. Nesse contexto, a resposta meramente punitiva não tem explicação racional e é desproporcional em relação a uma conduta que pode não ser saudável, mas que também não é prejudicial em relação a terceiros.

As reformulações operadas na política de drogas portuguesa partiram, ainda, da constatação de que, ao contrário do preconizado pelo proibicionismo, tratar o consumo de drogas por meio do sistema criminal, longe de tutelar a saúde pública colaborava para sua ineficácia, uma vez que dificulta a procura voluntária de tratamento pelos eventuais dependentes de drogas ou por pessoas acometidas por crises de intoxicação aguda em situações de uso abusivo. A criminalização faz com que os consumidores de drogas se sintam amedrontados pelo receio de uma pena criminal ou mesmo pela necessidade da confissão de um crime com toda estigmatização dela decorrente, com evidentes reflexos em termos laborais e de inserção na sociedade.

A Política Nacional de Drogas é formulada e coordenada pelo Instituto da Droga e da Toxicodependência (IDT) e sua implementação se baseia em cinco grandes eixos de ações: prevenção, dissuasão, redução de riscos e danos, tratamento e reinserção social.

As ações preventivas são realizadas através de campanhas informativas em geral dirigidas a grupos de potenciais consumidores. As campanhas de largo alcance apresentam um baixo índice de efetividade e podem, inclusive, surtir efeito contrário ao pretendido quando desperta a curiosidade de um que público ainda desconheça as potencialidades das 
drogas ou de alguma droga específica. Dessa forma, as campanhas televisivas, foram substituídas por ações dirigidas a públicos específicos (escolas, estudantes universitários, imigrantes e desempregados), tendo cada campanha suas especificidades, em termos de mensagem e argumentos, de acordo com as necessidades e cultura de cada um desses grupos. Também são realizadas ações informativas de intervenção direta com os promotores atuando nas chamadas cenas de uso, clubes noturnos, shows e outros ambientes que propiciam o uso de drogas.

Para operacionalizar o eixo de ações dissuasivas foram criadas as Comissões para a Dissuasão da Toxicodependência. Essas comissões são organismos administrativos que funcionam na forma de grupos multidisciplinares com competência regionalizada ${ }^{130}$. Elas recebem as pessoas apanhadas na posse das substâncias proibidas e buscam informá-las e dissuadi-las dessa prática. Também têm o poder de aplicar sanções administrativas ${ }^{131}$ e de encaminhá-las para tratamento, desde que obtido o seu consentimento.

Na realidade, numa primeira ocorrência, a intervenção da comissão se limita a uma abordagem onde são tratadas questões como: motivações e histórico do consumo, frequência e uso compulsivo e abusivo, repercussões no âmbito familiar e laboral e, não sendo caso de dependência (hipótese na qual a comissão empreenderá novas tentativas, caso não obtenha o convencimento do autuado para adesão a um tratamento), suspenderá o procedimento sem a imposição de nenhuma sanção. Todavia, a ocorrência fica registrada no IDT para hipótese de reincidência quando, aí sim serão aplicadas a coima ou outra modalidade de restrição de direitos, como prestação de serviços comunitários, suspensão de habilitação para dirigir veículos, obrigatoriedade de comparecimento para prestar informações etc.. O não cumprimento da sanção imposta é considerado crime de desobediência. $^{132}$

A partir da opção descriminalizante, as atividades de redução de riscos e danos puderam ser consolidadas e sistematizadas. Elas são articuladas por departamento próprio do IDT e atualmente financia 69 projetos em todo o país, e dispõe de 30 equipes de

\footnotetext{
${ }^{130}$ Cada comissão é formada por três membros: um da área jurídica e os outros dois da área de saúde ou assistência social, sendo assessorados por equipes técnicas multidisciplinares. Cada um dos dezoito distritos (divisão geográfica) portugueses dispõe de uma comissão. Nesse sentido: DOMOSTAWSKI, Artur. Política da droga em Portugal: os benefícios da descriminalização do consumo de drogas. Global Drug Policy Program, Open Society Foundations, 2011. p. 31.

${ }^{131}$ A principal delas é a chamada coima: sanção de natureza pecuniária embora não se confunda com as multas, administrativas ou penais. Podem variar entre 30 a 40 euros, com aumentos gradativos no caso de reincidência.

${ }^{132}$ DOMOSTAWSKI, Artur. op. cit., p. 33.
} 
técnicos especializados que trabalham nas ruas e em centros de acolhimento, providenciando, dentre outras ações, metadona a dependentes de heroína e albergues para consumidores sem-teto.

A esmagadora maioria desses projetos são operados por organizações não governamentais, ONG's, com financiamento estatal, obtido por concorrências públicas realizadas pelo IDT. Essa solução foi adotada com apoio na experiência internacional no trabalho de campo de redução de danos, que indica a maior eficácia se realizado por agentes de saúde comunitários, em geral usuários em tratamento ou ex-usuários, especialmente treinados para a abordagem de grupos específicos com os quais mantém vínculos ${ }^{133}$ proporcionando, dessa forma, um melhor acesso às pessoas na rua $\mathrm{e}$ estabelecendo uma relação de confiança entre os prestadores de serviços e os consumidores. Essas equipes são, também, muiltidisciplinares e trabalham disponibilizando informações, providenciando serviços e encaminhamentos e trocando seringas e agulhas utilizadas por kits ${ }^{134}$ novos.

O tratamento oferecido ao usuário dependente é disponível em todo território nacional através de uma rede de serviços públicos ou financiados pelo sistema público, como clínicas e comunidades terapêuticas, de qualquer forma referenciados pelo IDT. O centro de referência na área de tratamento é a Unidade de Desabituação - Centro de Taipas, localizado nas proximidades de Lisboa. O modelo de tratamento é notadamente ambulatorial com possibilidade de internação, quando indicada, especialmente para desintoxicação e por períodos de, no máximo, duas semanas.

Finalmente, um interessante eixo de ações de reinserção social complementa a ampla rede de atenção às pessoas que usam drogas, em conformidade com a Política de Drogas Portuguesa. As equipes de reinserção social trabalham em consonância com as unidades de tratamento e realizam um levantamento prévio das condições da pessoa em tratamento para posteriormente, em conjunto com ela planejarem ações com metas concretas visando a qualificação do indivíduo para o retorno ao trabalho, sua recolocação no mercado e outros aconselhamentos.

Além disso, respeitando o sigilo, buscam sensibilizar a sua própria comunidade (escola, emprego, etc.) com o intuito de superar o preconceito e preparar o regresso do

\footnotetext{
${ }^{133}$ No Brasil esse agente de saúde foi denominado redutor de danos.

${ }^{134} \mathrm{O}$ kit é composto, além de seringa e agulha esterilizadas, de utensílios de higiene como gaze e água esterilizada e camisinhas. Vide: DOMOSTAWSKI, Artur. op. cit., p. 36.
} 
indivíduo à sua vida normal. O IDT mantem, ainda, programas de incentivo a empresas que empregam dependentes em tratamento, com financiamento de estágios e outras modalidades de apoio.

Ainda na atividade de reinserção, uma importante ação é desenvolvida no sentido de garantir acesso à habitação. Foi constatado que muitos abandonos de tratamento foram motivados pela falta de um local para a moradia próximo da unidade de atenção à saúde. Assim, após uma avaliação de sua situação familiar, esses indivíduos podem candidatar-se a viver em apartamentos do próprio IDT por um período de 6 a 12 meses. Há um compartilhamento de vagas com outras pessoas que se encontram na mesma situação e, nesse período, são implementadas as ações que lhes permitam assegurar uma moradia com os seus próprios recursos.

Após dez anos de sua implantação, contrariando as críticas inicialmente recebidas, a nova política portuguesa, apresentou resultados que mereceram atenção mundial. Primeiramente, ficou estatisticamente demonstrado que, ao contrário do que é propalado pelo senso comum, o número de consumidores de drogas não aumentou dramaticamente em decorrência da descriminalização, chegando mesmo a diminuir em algumas categorias ${ }^{135}$. Por outro lado, o número de pessoas com doenças relacionadas com o uso de drogas (como AIDS e Hepatites B ou C) diminuiu significativamente. Enfim, os níveis de consumo de drogas em Portugal são dos mais baixos da União Europeia. ${ }^{136}$

Atualmente, embora a política de drogas venha recebendo críticas com relação a seu custo, principalmente diante da grave crise econômica que assola a Europa e muito especialmente Portugal, a descriminalização e todo o arcabouço principiológico que a sustenta encontra uma aprovação quase consensual da parte da sociedade portuguesa e é reconhecida como um paradigma para a elaboração de alternativas viáveis ao proíbicionismo, que se mostrou completamente ineficaz com relação às suas finalidades declaradas.

\footnotetext{
${ }^{135}$ Por exemplo, a prevalência de consumo de heroína entre os $16 / 18$ anos caiu de $2.5 \%$ em 1999 para $1.8 \%$ em 2005. Nesse sentido, vide: GREENWALD, G. Drug decriminalization in Portugal: lessons for creating fair and successful drug policies. The Cato Institute, 2009. p. 14.

${ }^{136}$ Conferir: EUROPEAN MONITORING CENTER FOR DRUGS AND DRUG ADDICTION (EMCDDA), Statistical Bulletin 2010. Disponível em: <http://www.emcdda.europa.eu/stats10>, "Lifetime prevalence of drug use in Nationwide surveys among the general population." Apenas 8 de 28 países avaliados apresentam um nível inferior ao de Portugal no consumo de cannabis, 10 de 27 - cocaína, 4 de 27 anfetaminas, 4 de 27 - ecstasy, 5 de 23 - LSD.
} 


\section{A REDUÇÃO DE DANOS PARA ALÉM DA “QUESTÃo DAS DROGAS"}

\subsection{Breve nota introdutória}

Culminando a hipótese inicialmente considerada, vale dizer, a adoção do modelo da redução de danos no âmbito da Política Criminal, resta-nos indagar de suas possibilidades para além da questão das drogas. Temos que, na atualidade, outros temas igualmente complexos comportam a mesma abordagem.

Tratam-se de fenômenos sociais multifacetados, cuja conduta se viu criminalizada e que, como na questão das drogas, recebem a atenção especial da saúde pública.

Mas não só, o debate social que se trava sobre eles enfeixa aspectos morais, éticos, biopsico-sociais, políticos, antropológicos, filosóficos, jurídicos e de saúde pública. Dessa forma, a abordagem adequada será a interdisciplinar e, nesse sentido, tanto quanto na questão das drogas, a saúde pública já impulsiona sua política rumo a novas alternativas que congregam os elementos propostos pelo modelo de redução de danos, isto é, situações de vulnerabilidade das quais decorrem ações práticas fundadas no respeito à dignidade humana.

Podemos assim, já num primeiro momento ampliativo, apontar duas possibilidades: a redução de danos em casos de aborto ilegal e a redução de danos na terminalidade da vida.

\subsection{A Redução de danos e o aborto}

Segundo a Organização Mundial de Saúde (OMS), todos os anos e em todas as partes do mundo milhares de mulheres estão morrendo em conseqüência da prática de abortamento inseguro ${ }^{137}$. Trata-se de uma causa de morte materna perfeitamente evitável e que, não obstante isso, tem atingido de setenta a oitenta mil mulheres por ano. No Brasil,

\footnotetext{
${ }^{137}$ Prescreve a OMS (Organização Mundial de Saúde), que o abortamento inseguro é aquele procedimento realizado para interromper uma gravidez, praticado por pessoal sem qualificação ou aquele realizado sem condições de segurança médica, ou ambos (ORGANIZAÇÃO MUNDIAL DE SAÚDE. Saúde. Aborto sem riscos: guia técnico e políticas para sistemas de saúde. Genebra: OMS, 2003).
} 
em especial, o abortamento inseguro constitui uma das principais causas de morte materna $^{138}$.

Esse foi o motivo que levou o Comitê sobre Direitos Econômicos, Sociais e Culturais da ONU a recomendar que sejam adotadas medidas eficazes "com a finalidade de proteger as mulheres dos efeitos dos abortos clandestinos e inseguros, assegurando que as mulheres não recorram a tais procedimentos prejudiciais" ${ }^{\prime 39}$, quando tratou de sua preocupação com a mortalidade materna no Brasil.

Ademais, deve-se ter em conta que as mortes de mulheres relacionadas ao aborto são apenas a parte mais visível do problema, pois são inúmeras as comorbidades a ele relacionadas ou dele decorrentes, sejam de natureza física, psíquica ou social ${ }^{140}$.

É necessário e possível sairmos do campo da elaboração formal de princípios e da produção legislativa para enfrentar o problema no âmbito material com a implementação de políticas públicas que visem a diminuição dos riscos e danos a que estão expostas as mulheres que se encontram nessa situação, notadamente aquelas provenientes de populações mais pobres e marginalizadas.

Do ponto de vista formal, não se pode esquecer que o Brasil ratificou tratados e convenções internacionais de direitos humanos e, nessa medida, incorporou-os ao seu sistema constitucional de garantias ${ }^{141}$. Dessa forma, assumiu o expresso compromisso de garantir às mulheres uma assistência plena à sua saúde sexual e reprodutiva, o que o obriga a enfrentar essa flagrante violação dos direitos humanos das mulheres, não apenas no

\footnotetext{
${ }^{138}$ TORRES, José Henrique Rodrigues. Aborto inseguro: é necessário reduzir riscos. Revista Brasileira de Ciências Criminais, São Paulo, n. 68, p. 27, 2007.

${ }^{139}$ PRESIDÊNCIA DA REPÚBLICA. Secretaria Especial dos Direitos Humanos. Comitê sobre Direitos Econômicos, Sociais e Culturais. Direitos Humanos, Econômicos, Sociais e Culturais. O cumprimento do Piedesc pelo Brasil. Plataforma Brasileira de Direitos Humanos, Econômicos, Sociais e Culturais Plataforma DhESC Brasil. Brasília, 2003.

${ }^{140}$ Explicitando esses aspectos, confira-se: TORRES, José Henrique Rodrigues, op. cit.

${ }^{141}$ Nos termos da Constituição Federal, artigo $5^{\circ}$, parágrafos $1^{\circ}, 2^{\circ}$ e $3^{\circ}$ : os tratados internacionais de direitos humanos ratificados pelo Brasil têm natureza constitucional. O Congresso Nacional ratificou a Convenção Interamericana para prevenir, punir e erradicar a violência contra a mulher - "Convenção de Belém do Pará" (1994), em 27 de novembro de 1995, a Convenção Interamericana para prevenir e punir torturas (1985) em 20 de julho de 1989, a Convenção Americana de Direitos Humanos - "Pacto de San José da Costa Rica" (1969), em 25 de setembro de 1992, a Convenção contra a tortura e outros tratamentos ou penas cruéis, desumanos ou degradantes (1984), em 28 de setembro de 1989, a Convenção sobre a eliminação de todas as formas de discriminação contra a mulher (1979), em $1^{\circ}$ de fevereiro de 1984 , e o Pacto Internacional dos Direitos Civis e Políticos (1966), em 24 de janeiro de 1992.
} 
campo jurídico-formal, mas, principalmente, com políticas públicas inclusivas, efetivas e eficientes $^{142}$.

Há frutíferas experiências nesse campo, como no caso de nosso vizinho, o Uruguai, que recentemente adotou um programa de redução de riscos e danos frente ao aborto inseguro decorrente de gravidez indesejada ${ }^{143}$.

No Brasil, até recentemente ${ }^{144}{ }^{145}$, permanecíamos adstritos à discussão do abortamento sob seu aspecto estritamente legal, no plano político e ideológico, sem que fossem adotadas políticas públicas sanitárias que visassem a, pelo menos, transformar o "aborto inseguro" em "aborto de menor risco", como já estava sendo feito naquele país latino-americano ${ }^{146} \mathrm{e}$, recentemente, iniciou-se a implantação de novas balizas normativas que indicam a adoção de política pública semelhante pelo Ministério da Saúde.

É fato inegável que o abortamento, considerado em sua dimensão estritamente de saúde pública, pode ser decomposto em distintas etapas temporais de caráter preparatório, executório, além de seu resultado e suas consequências. Dessa forma, é perfeitamente possível a limitação temporal da execução, propriamente dita. Assim sendo, é factível a adoção, dentro da legalidade estrita, de políticas públicas sanitárias para acolher as mulheres durante esses momentos temporais extremos do abortamento ilícito.

\footnotetext{
${ }^{142}$ Está expressamente declarado na Convenção de Pequim, que "os direitos da mulheres são direitos humanos" e é afirmado o direito à assistência à saúde sexual e reprodutiva das mulheres; na Declaração e no Programa de Viena, são reconhecidos os direitos das mulheres à igualdade, à tolerância e à dignidade; no Pacto Internacional sobre Direitos Econômicos, Sociais e Culturais, os Estados assumem a obrigação de criar condições que assegurem a todos assistência médica plena; na Convenção sobre a eliminação de todas as formas de discriminação contra a mulher (CEDAW), são reconhecidos os direitos à assistência à saúde sexual e reprodutiva da mulheres e os Estados comprometem-se a proteger as mulheres dos efeitos negativos à saúde causados pelo abortamento; e na Convenção Interamericana para prevenir, punir e erradicar a violência contra a mulher (Convenção de Belém do Pará), é reconhecido o direito das mulheres a uma vida livre da morte materna evitável.

${ }^{143}$ Uma vez verificado que o aborto inseguro constituía a primeira causa de morte materna, o Ministério da Saúde Pública do Uruguai aprovou, em 2004, a Normativa, que começou a ser oficialmente aplicada, nos termos da Ordenanza 369-04 / MSP, complementada, depois, por duas novas normativas: consulta pré aborto e consulta post aborto.

${ }^{144}$ No ano de 2010 o Ministério da Saúde publicou uma revisão de sua norma técnica; “Atenção humanizada ao abortamento" (anexo 6) na qual estabelece os procedimentos necessários e devidos à mulher, tanto nos casos de aborto legal, quanto, especialmente, no que diz respeito à atenção e acolhimento nas fases pré e pós abortamento.

${ }^{145}$ Vide anexo 6.

${ }^{146}$ Conforme os termos prescritos pela Conferência Mundial sobre as Mulheres (Plataforma de Ação de Beijing), o Brasil comprometeu-se a reformar as leis que estabelecem medidas punitivas contra as mulheres que tenham sido submetidas a abortos ilegais. E, em reforço a essas medidas, o relatório do Comitê CEDAW (Comitê sobre a Eliminação da Discriminação contra a Mulher), aponta que a existência de leis punitivas em relação ao abortamento é o que leva as mulheres à prática de abortos inseguros e, portanto, seu efeito é deletério pois incrementa o risco de morte e demais comorbidades.
} 
Esse foi, em linhas gerais, o paradigma adotado pelo Uruguai na formulação de sua nova política de saúde para o acolhimento das gestantes: o estabelecimento do "antes" e "depois" do abortamento ilícito, para que sejam garantidos plenamente os direitos das mulheres à assistência médica integral e eliminados ou pelo menos diminuídos os riscos (antes) e danos (depois) inerentes ou decorrentes do abortamento clandestino.

Não obstante a adoção dessas estratégias, que se destaca como necessária, é certo que o aborto não é um fato desejável, quer se tenha em conta a ótica feminina quer se adote a perspectiva da sociedade de modo geral. Por outro lado, todo esse conjunto de medidas não invalida nem minimiza o trabalho preventivo visando a evitar a gravidez indesejada e a prática do abortamento clandestino.

Dito isso e agora examinando aspectos objetivos de nosso ordenamento legal, o fato é que perante a legislação penal brasileira, o abortamento não é criminoso em duas hipóteses previstas expressamente no artigo 128 do Código Penal: (1) abortamento necessário, que é aquele autorizado como única forma de salvar a vida da gestante; e (2) abortamento sentimental, quando a gravidez resulta de estupro. Tem sido autorizado, ainda, através de decisões judiciais, o abortamento nos casos de malformação fetal incompatível com a vida extra-uterina, com base nos princípios fundantes do sistema jurídico e nos tratados internacionais de direitos humanos.

Todavia, as hipóteses de licitude da prática abortiva previstas em nossa legislação e aquela que vem sendo admitida judicialmente estão longe, a toda evidência, de abarcar a totalidade do problema do abortamento inseguro.

A corroborar essa afirmação basta a singela constatação de que, embora seja um direito $^{147}$, as mulheres no Brasil não conseguem exercê-lo nem mesmo nos casos de abortamento lícito. Essa afirmação não implica em desprezo aos avanços ocorridos, especialmente com a explicitação dos procedimentos terapêuticos devidos relacionados na Norma Técnica do Ministério da Saúde denominada "Atenção humanizada ao abortamento", publicada em $2010^{148}$, contudo, a oferta de serviços de atenção e cuidado às gestantes para a prática do abortamento lícito ainda é mínima e deficitária.

\footnotetext{
${ }^{147}$ Confira-se nesse sentido: UNITED NATIONS GENERAL ASSEMBLY. Programme of Action of the International Conference on Population and Developement. New York: United Nations, 1994: "Os direitos sexuais e reprodutivos, como parte integral dos direitos humanos, implicam o direito à interrupção da gestação nos casos legalmente autorizados pelo sistema jurídico" e artigo 196 da Constituição Federal Brasileira.

${ }^{148}$ Vide anexo 6.
} 
Resta claro que as hipóteses legais de aborto são insuficientes, pois, não dão respostas às causas sociais e econômicas, bem como ao aborto por livre opção diante de uma gravidez indesejada, que são as motivações mais frequentes para a prática do aborto clandestino. Tanto isso é verdade que suas taxas de incidência permanecem elevadas.

Remarque-se que o abortamento é problema de saúde pública e deve ser tratado com o instrumental próprio dessa área, tais como: a) a educação sexual e reprodutiva; b) o acesso aos meios contraconceptivos. Todas essas possibilidades foram contempladas na nova normativa adotada pelo Ministério da Saúde, bem como foram disciplinados procedimentos padrões para todos os serviços de atenção à saúde sexual e reprodutiva da mulher, integrantes da rede do Sistema Único de Saúde (SUS).

Além disso, sendo o abortamento um problema de saúde pública sua criminalização se mostra um evidente equívoco. Sua manutenção tem efeitos apenas ideológicos e simbólicos e não colabora com a solução efetiva do problema, ao contrário incrementa de forma exponencial os riscos e danos inerentes e decorrentes do abortamento clandestino.

Portanto, é urgente e necessário que se abra o debate nacional com vistas à descriminalização do aborto como já fizeram, dentre outros, a Alemanha,a Escócia, a Holanda, a Dinamarca, a Suécia, a Áustria, a República Checa, a Eslováquia, a Bulgária, a Romênia, a Grécia, a Hungria, a Itália, a Bélgica, a França, o Reino Unido e até mesmo Portugal.

Mas, enquanto esse ideal não é atingido, urge seja efetivamente implantado o programa descrito na nova normativa do Ministério da Saúde que, em última análise, contempla ações preventivas de redução de riscos e danos do abortamento inseguro para garantir às mulheres o direito à assistência plena a sua saúde ${ }^{149}$.

\subsection{A Redução de danos e a terminalidade da vida: a ortotanásia}

Vivemos num curso da história no qual as ciências médicas têm experimentado um espetacular avanço, notadamente se considerarmos questões como a terminalidade da vida.

\footnotetext{
${ }^{149}$ Conforme mostra José Henrique Torres (op. cit.), tem sido reiterada e cientificamente demonstrado que no aborto assistido, como ocorre nos países que não o criminalizaram, raramente acontece a morte materna. As comorbidades causadas pelo abortamento são praticamente desconhecidas nesses países. Por outro lado, quanto mais restritivas são as leis relativas ao aborto, maiores são as complicações decorrentes de sua prática e maiores são as possibilidades de morte materna.
} 
As novas tecnologias têm propiciado a manutenção da vida humana em condições até então inimagináveis, em contrapartida, toda essa parafernália impõe aos pacientes a sujeição a tratamentos de questionável eficácia, mas comprometedores da qualidade de vida, muitas vezes involuntários. Nesse contexto, a morte acabou sendo percebida como fracasso terapêutico.

Diante desse quadro, é necessário um redimensionamento do próprio papel do médico e de suas atribuições. O dever de agir do médico está condicionado à possibilidade de cumprir a sua função curativa.

Uma vez afastada essa condição, não se pode falar em omissão relevante e, assim, abrem-se novas hipóteses que possibilitam uma revaloração da terminalidade da vida, notadamente tendo em conta valores constitucionais como a dignidade humana, tudo a excluir a possibilidade de criminalização da conduta do profissional de saúde.

No campo da ética, a eutanásia é um dos temas mais polêmicos e delicados e, em geral, a palavra tem sido entendida e reduzida ao seu significado de "boa morte". Essa definição de eutanásia não compreende de forma completa o debate atual. Ao longo do tempo a palavra eutanásia sofreu mudanças e tem seu sentido moderno atribuído a Francis Bacon (1605), que aos médicos sugeria "ao mesmo tempo aperfeiçoar sua arte e dar assistência para facilitar e suavizar a agonia e os sofrimentos da morte" ${ }^{150}$.

$\mathrm{Na}$ atualidade, "poderíamos definir a eutanásia como o fato de provocar diretamente a morte de um ser humano (ou de um animal), de tal modo que essa morte advenha rapidamente e sem sofrimento, seja agindo para esse fim, seja abstendo-se de agir: no primeiro caso, fala-se de eutanásia ativa, no segundo, de eutanásia passiva,. A intenção daquele que provoca a morte deve ser livrar aquele que está para morrer de uma condição insuportável: entende-se com isso, em geral, sofrimentos intoleráveis ou uma situação de indignidade e de desamparo extremo provocado pela doença"151

A distanásia, por seu turno, é a denominação científica da conduta médica que se caracteriza por uma obstinação diagnóstica e terapêutica, com um forte componente de autoritarismo. Etimologicamente, a palavra tem origem grega e significa: "morte difícil e penosa".

\footnotetext{
${ }^{150}$ OLIVEIRA, Reinaldo Ayer de. Eutanásia, distanásia e ortotanásia. Apostilas de Bioética. Bioética e Direito/USP, 2009. No prelo.

${ }^{151}$ CANTO-SPERBER, M, org. Dicionário de ética e filosofia moral. São Leopoldo, RS: Ed. Unisinos; 2003. v. 1, p. 603.
} 
$\mathrm{Na}$ atualidade, o conceito de distanásia indica o prolongamento do processo da morte, por meio de técnicas terapêuticas extraordinárias que apenas têm o objetivo de prolongar a vida biológica do doente, impondo, ao paciente e seus familiares, dor e sofrimento diante da irreversibilidade do quadro.

Nesse contexto, as condutas distanásicas podem estar relacionadas com:

1. A convicção de que a vida é um bem absoluto e, portanto, a morte surge como fracasso terapêutico, não se levando em consideração a qualidade da vida;

2. Um autoritarismo na relação médico-paciente que leva a um desprezo pela vontade do doente e de seus familiares;

3. A angústia do médico diante do insucesso terapêutico e a resistência em aceitar a morte do doente. ${ }^{152}$

Entre esses dois extremos surge uma terceira via, a Ortotanásia, cujo significado se refere às atitudes que vão sendo assumidas na perspectiva do bem-estar do doente, quando as possibilidades de diagnóstico e tratamento de uma enfermidade grave e incurável foram sendo vencidas, progressivamente.

Num quadro dessa natureza, "a ortotanásia permite ao doente que já entrou na fase final e aos que o cercam enfrentarem a morte com certa tranqüilidade, porque, nesta perspectiva, a morte não é uma doença a curar, mas sim algo que faz parte da vida. Uma vez aceito esse fato que a cultura ocidental moderna tende a esconder e negar abre-se a possibilidade de trabalhar com as pessoas a distinção entre curar e cuidar, entre manter a vida quando este é o procedimento correto e permitir que a pessoa morra quando sua hora chegou". 153

Também é preciso ser considerado que, mesmo para as ciências médicas, há uma grande dificuldade em definir, de forma clara e objetiva, quando a vida termina. Frequentemente, a morte está associada a um acontecimento súbito. Não obstante, existem situações em que a morte era esperada porque a pessoa estava doente.

Há até pouco tempo, o senso comum entendia que a morte significava a parada do coração ou, cientificamente, a interrupção irreversível dos batimentos cardíacos. A cessação da circulação e da respiração significava o fim da vida.

\footnotetext{
${ }^{152}$ LEONE, Salvino; PRIVITERA, Salvatore; CUNHA, Jorge Teixeira da (Coords.). Dicionário de bioética. Aparecida, SP: Ed. Santuário; 2001.

${ }^{153}$ PESSINI, L. Distanásia: até quando prolongar a vida. São Paulo: Loyola; 2001.
} 
O conceito de morte ligado à parada do coração, em caráter definitivo, sofreu um abalo nos anos 1960 em virtude da possibilidade de reversão da parada cardíaca e da respiração por meio de manobras de massagem cardíaca e a instituição de uma ventilação pulmonar artificial.

Dessa forma, na hipótese de uma parada cardiorrespiratória um indivíduo que disponha de uma técnica adequada tem a possibilidade de ressuscitar um outro individuo.

Todavia, nesse processo, pode ocorrer uma lesão grave do sistema nervoso central, decorrente da baixa oxigenação do tecido cerebral durante as manobras de ressuscitação, que resulte num estado de comprometimento daquele sistema vital. Quando "ocorre a lesão irreversível do tronco cerebral e do córtex cerebral, por injúria direta ou falta de oxigenação, por um tempo, em geral, superior a 5 minutos em adulto em normotermia estamos diante da morte encefálica". ${ }^{154}$

A mudança definitiva da concepção da morte se dá com o advento dos transplantes de órgãos e tecidos, especialmente com os transplantes cardíacos que possibilitaram a retirada do coração sem interrupção de seus batimentos, inaugurou-se uma nova forma de abordar a terminalidade da vida.

Os transplantes romperam uma barreira conceitual introduzindo a noção de morte encefálica como critério de morte da pessoa humana com possível disponibilidade de órgãos e tecidos do seu corpo.

A ocorrência da morte deixou de ser considerada um fenômeno súbito, terminal e passou a ser compreendida como a culminância de um processo de terminalidade. No final dos anos 80, com o desenvolvimento de sofisticados equipamentos de recuperação e preservação de determinadas funções orgânicas vitais, criou-se a possibilidade de implementar uma verdadeira revolução nos tratamentos de doentes graves. Sobretudo com a criação das unidades de terapia intensiva, concentrando recursos materiais e disponibilizando pessoal altamente qualificado, propiciando, então, a expectativa de continuidade da vida em situações extraordinárias.

Contudo, apesar do avanço científico-tecnológico, há situações de irreversibilidade que levam pessoas à morte. A constatação da falência de órgão, sistema e/ou tecido,

\footnotetext{
${ }^{154}$ TIMERMAN A, CÉSAR, L. A. M.; TIMERMAN, S, VIEIRA S. R. R. (Coords.). Consenso Nacional de Ressuscitação Cardiorrespiratória. Arquivos Brasileiros de Cardiologia, São Paulo, v. 66, n. 6, p. 375-402, 1996.
} 
determinou a construção de protocolos de prognósticos, que definem, com razoável probabilidade, a possibilidade de evolução para a morte de uma pessoa com o diagnóstico de, por exemplo, choque irreversível.

Nesse passo, a falência do sistema nervoso central passou a ser considerada como o critério de morte cerebral e entendida, portanto, como morte da pessoa humana.

A morte encefálica, expressão da irreversibilidade das lesões do sistema nervoso central, adquiriu um estatuto próprio e sua definição passou a ser estabelecida por lei e normas complementares. No Brasil a Resolução $\mathrm{n}^{\mathrm{o}}$ 1.480/97 do Conselho Federal de Medicina ${ }^{155}$, a Lei $\mathrm{n}^{\mathbf{0}}$ 9.434/97 - Lei dos Transplantes ${ }^{156}$ e a Resolução CFM no. $1.826 / 07^{157}$ são os instrumentos legais que disciplinam os protocolos para a constatação da morte encefálica.

Todas essas circunstâncias convergiram para provocar modificações nos paradigmas da própria deontologia médica, que passou a destacar a autonomia do paciente, sua qualidade de vida e a própria valorização da dignidade humana, como fatores recondicionantes desse debate que terminaram por reorientar as relações médico-paciente.

No Estado de São Paulo tivemos o advento da Lei n. 10.241, de 17 de março de $1999^{158}$, que ficou conhecida como Lei Mário Covas ${ }^{159}$, e que autoriza o paciente a recusar tratamentos extraordinários de manutenção de vida.

\footnotetext{
${ }^{155}$ BRASIL. Conselho Federal de Medicina. Resolução n. 1.480, de 8 de agosto de 1997. Dispõe sobre os critérios de morte encefálica. Diário Oficial da União, Poder Executivo, Brasília, DF, n. 160, 21 ago. 1997. Seção $\quad 1, \quad$ p.18.227-8. $\quad$ Disponível em: <http://www.cremesp.org.br/library/modulos/legislacao/versao_impressao.php?id=3004>. Acesso em: 04 set. 2008.

${ }^{156}$ BRASIL. Lei n. 9.434, de 4 de fevereiro de 1997. Dispõe sobre a remoção de órgãos, tecidos e partes do corpo humano para fins de transplante e tratamento e dá outras providências. Diário Oficial da União, Poder Executivo, Brasília, DF, 05 fev. 1997. Seção 1. Disponível em: $<$ http://www.planalto.gov.br/ccivil_03/Leis/L9434.htm>. Acesso em: 04 set. 2008.

${ }^{157}$ BRASIL. Conselho Federal de Medicina. Resolução n. 1.826, de 24 de outubro de 2007. Dispõe sobre a legalidade e o caráter ético da suspensão dos procedimentos de suportes terapêuticos quando da determinação de morte encefálica de indivíduo não-doador. Diário Oficial da União, Poder Executivo, Brasília, DF, 06 dez. 2007. Seção I, p. 133. Disponível em: $<$ http://www.cremesp.org.br/library/modulos/legislacao/versao_impressao.php?id=7587>. Acesso em: 04 set. 2008.

${ }^{158}$ SÃ̃ PAULO (Estado). Lei n. 10.241, de 17 de março de 1999. Dispõe sobre os direitos dos usuários dos serviços e das ações de saúde no Estado e dá outras providências. Diário Oficial do Estado, Poder Executivo, São Paulo, n. 51, de 18 mar. 1999. Seção 1, p. 1. Disponível em: $<$ http://www.cremesp.org.br/library/modulos/legislacao/versao_impressao.php?id=3080>. Acesso em: 04 set. 2008.

${ }^{159} \mathrm{O}$ ex-governador Mário Covas foi, possivelmente, o primeiro a se valer das prerrogativas estabelecidas pela nova lei que promulgara, quando, vítima de um câncer e em estado de irreversibilidade de seu quadro, opôs-se à dar continuidade ao tratamento inútil e preferiu passar seus últimos dias em sua residência na companhia de amigos e familiares.
} 
Mais recentemente, no ano de 2009, o próprio Código de Ética Médica ${ }^{160} /{ }^{161}$ foi reformado e nele foram introduzidas modificações substanciais com reflexos diretos nesse tema estabelecendo como princípios fundamentais os seguintes tópicos:

VI - O médico guardará absoluto respeito pelo ser humano e atuará sempre em seu benefício. Jamais utilizará seus conhecimentos para causar sofrimento físico ou moral, para o extermínio do ser humano ou para permitir e acobertar tentativa contra sua dignidade e integridade.

XXI - No processo de tomada de decisões profissionais, de acordo com seus ditames de consciência e as previsões legais, o médico aceitará as escolhas de seus pacientes, relativas aos procedimentos diagnósticos e terapêuticos por eles expressos, desde que adequadas ao caso e cientificamente reconhecidas.

XXII - Nas situações clínicas irreversíveis e terminais, o médico evitará a realização de procedimentos diagnósticos e terapêuticos desnecessários e propiciará aos pacientes sob sua atenção todos os cuidados paliativos apropriados.

Nessa mesma linha, em secção específica que versa sobre Direitos Humanos, fica expressamente estabelecido que é vedado ao médico:

Art. 22 - Deixar de obter consentimento do paciente ou de seu representante legal após esclarecê-lo sobre o procedimento a ser realizado, salvo em caso de risco iminente de morte.

Art. 24 - Deixar de garantir ao paciente o exercício do direito de decidir livremente sobre sua pessoa ou seu bem-estar, bem como exercer sua autoridade para limitá-lo.

Art. 26 - Deixar de respeitar a vontade de qualquer pessoa, considerada capaz física e mentalmente, em greve de fome, ou alimentá-la compulsoriamente, devendo cientificá-la das prováveis complicações do jejum prolongado e, na hipótese de risco iminente de morte, tratá-la.

Art. 29 - Participar, direta ou indiretamente, da execução de pena de morte.

${ }^{160}$ BRASIL. Conselho Federal de Medicina. Resolução n. 1.931, de 17 de setembro de 2009. Aprova o Código de Ética Médica. Diário Oficial da União, Poder Executivo, Brasília, DF, de 24 set. 2009. Seção 1, p. 90-92. Disponível em: <http://www.abdir.com.br/legislacao/legislacao_abdir_24_9_09_1.pdf>.

${ }^{161}$ Vide anexo 5. 
Ainda no tocante à relação do facultativo com pacientes e familiares, o novo código estabelece expressamente que é também vedado:

Art. 31 - Desrespeitar o direito do paciente ou de seu representante legal de decidir livremente sobre a execução de práticas diagnósticas ou terapêuticas, salvo em caso de iminente risco de morte.

Art. 32 - Deixar de usar todos os meios disponíveis de diagnóstico e tratamento, cientificamente reconhecidos e a seu alcance, em favor do paciente.

Art. 41 - Abreviar a vida do paciente, ainda que a pedido deste ou de seu representante legal.

Parágrafo único. Nos casos de doença incurável e terminal, deve o médico oferecer todos os cuidados paliativos disponíveis sem empreender ações diagnósticas ou terapêuticas inúteis ou obstinadas, levando sempre em consideração a vontade expressa do paciente ou, na sua impossibilidade, a de seu representante legal.

Todo esse arcabouço ético-jurídico traz uma compreensão mais precisa e definitiva sobre a terminalidade da vida, nas situações em que medidas de manutenção artificial são adotadas, e abre novas perspectivas de soluções aos conflitos que permeiam o debate.

No caso da morte encefálica, que é constatada através de um diagnóstico preciso, com vários testes e exames, não existe nenhuma atividade do córtex cerebral e do tronco cerebral, ou seja, dos órgãos responsáveis pela respiração do indivíduo.

Por outro lado, é natural que ao conceituarmos vida precisamos levar em consideração, sobretudo, a integridade do indivíduo, que permite que ele se relacione com o seu meio, qualificando sua vida.

Ao retiramos ou suspendermos os tratamentos chamados fúteis, dispendiosos e/ou dolorosos, o médico admite que o paciente morra, inclusive se possível no seio de sua família, contando com seu apoio, e de todo modo, recebendo medicamentos paliativos para aliviar seu sofrimento.

Tomando agora a perspectiva do Direito Penal, segundo o modo de execução, a eutanásia pode ser ativa, quando a morte se dá por ato comissivo do agente ou passiva, quando a ação for omissiva como a consistente em deixar morrer, através da omissão ou interrupção de processos terapêuticos mantenedores da vida. Há que se apontar o entendimento majoritário no sentido de que o desligamento de aparelhos que mantêm 
artificialmente a vida constitui uma omissão uma vez que entende-se que equivaleria à interrupção de um processo terapêutico.

Ainda numa tentativa delimitadora do conceito tem-se que a eutanásia pressupõe a existência de consentimento do enfermo. Importa, nesse passo distinguir a eutanásia do homicídio consentido. Embora ambos contem com a anuência da vítima a eutanásia tem sempre a finalidade piedosa ou humanitária.

Dessa forma, ressalta-se que a hipótese que aqui se cogita como legitimada pela nova conformação ético-legal do ordenamento brasileiro é aquela na qual a privação da vida alheia é perpetrada por razões humanitárias, com o consentimento do interessado, que sofre de uma enfermidade terminal incurável, tendo-se em conta o atual estágio das ciências médicas, bem como naquelas hipóteses em que o interessado não pode manifestar seu consentimento, embora esse possa ser suprido por manifestações anteriores de vontade.

Em geral, o médico assume uma posição de enfrentamento à morte. Desse posicionamento pode decorrer uma luta desenfreada pela manutenção da vida a qualquer custo, indiferentemente da vontade do paciente e de seus familiares. Pode também ser estabelecida uma condição de intransigência do médico quanto a real possibilidade de morte do doente. Tal conduta pode trazer como consequência a agonia prolongada, dor e sofrimento ao doente e seus familiares.

A alternativa a esses procedimentos obstinados, embora inúteis e dolorosos, implica na adoção de um conjunto de atitudes e procedimentos que, levando em consideração a dignidade da pessoa humana, põem em relevo seus direitos e sua autonomia de decidir sobre a própria morte. Nesses casos, considera-se que a retirada e suspensão de tratamentos dolorosos, inúteis e dispendiosos de manutenção de vida, possibilitam que o doente em fase terminal de doença grave e incurável e seus familiares compartilhem da decisão sobre o seu destino.

Os novos princípios deontológicos estabelecidos pelo Código de Ética Médica e pelas resoluções do Conselho Federal de Medicina, órgão que disciplina e fiscaliza a prática médica no Brasil, culminaram por permitir que o médico, no curso do processo terapêutico, possa limitar ou suspender procedimentos e tratamentos que prolonguem a vida do doente, em fase terminal, de enfermidade grave e incurável, respeitada a vontade da pessoa ou de seu representante legal. 
Importa ainda ressaltar que a prática médica continua a garantir que o doente receba todos os cuidados necessários para aliviar os sintomas que levam ao sofrimento, assegurada a assistência integral, o conforto físico, psíquico, social, espiritual, inclusive assegurando a ele o direito da alta hospitalar se assim o desejar.

Essa nova conformação ético-jurídica apóia-se na Constituição da República Federativa do Brasil que consagra como seu princípio fundante a dignidade da pessoa humana e, embora aceite a morte do paciente, deve ser tomada como uma estratégia de redução de danos, uma vez que, considerando o estado de vulnerabilidade daquele indivíduo, a imposição de procedimentos dolorosos, dispendiosos e inúteis, apenas serviria para prolongar seu sofrimento e não para dar-lhe qualidade de vida diante de um fato inexorável da existência humana, a sua finitude. 


\section{CONCLUSÃO}

O trabalho até aqui desenvolvido buscou analisar as perspectivas da política de redução de danos no âmbito das Ciências Criminais. Procurou, dessa forma, examinar as potencialidades da nova abordagem numa perspectiva criminológica e, especialmente, de política criminal. Para tanto, utilizou-se de uma abordagem interdisciplinar, sem se descurar dos reflexos no âmbito das Ciências Criminais, nossa área de interesse acadêmico, antes pelo contrário, visou a revelação de suas especificidades.

A pesquisa teve como meta, investigar se os programas e as ações concretas implementadas pelos agentes de saúde, operadores da política de redução de danos, têm impacto na criminalidade conexa às práticas de uso e comércio de drogas ilícitas. Pretendeu, assim, examinar se a política de saúde pública tem potencialidade para transpor os limites de sua área original e, ampliando sua atuação, ser utilizado no campo da política criminal.

Para tanto, procurou-se identificar um modelo abstrato que pudesse congregar as características dessa estratégia, servindo como paradigma para a sua aplicação em outras áreas do conhecimento.

Ao fim dessa empreitada, embora sem a pretensão de ter esgotado o assunto que ainda é absolutamente original, podemos apresentar uma síntese das conclusões que, nesse momento, parecem ser as mais pertinentes com o propósito original do trabalho:

1. No nosso atual modelo constitucional, diante do reconhecimento de direitos sociais que impõem uma prestação positiva do Estado, pode-se afirmar que as políticas públicas têm como meta, em linhas gerais, a concreção dos direitos e garantias fundamentais, podendo para tanto adotar medidas de cunho intervencionista, sem se descurar, no entanto, de que essa mesma intervenção também estará condicionada e, portanto, limitada por esses mesmos direitos e garantias constitucionais;

2. Há um amplo leque de políticas públicas que deve ser adotado de forma articulada, sistemática e complementar, para que seja possível atingir resultados satisfatórios com relação ao fenômeno criminal;

3. Nessa medida, as políticas sociais e a política criminal, devem ser articuladas num programa de governo, cabendo a cada uma delas um papel determinado e 
complementar. As primeiras têm como objetivo a promoção de uma melhor qualidade de vida da população em geral, tornando efetivos os seus direitos constitucionais, e, por outro lado, medidas de natureza preventivas ou repressivas implantadas com vistas à tutela da segurança pública e contenção da criminalidade são opções político-criminais;

4. Todavia, na atualidade, a Política Criminal não se resume numa análise valorativa das ações desviantes e na eleição das medidas cabíveis visando a eficaz prevenção e repressão do delito, abarcando também o conjunto dos aspectos fundamentais, nos termos da Constituição e do Ordenamento Penal, que devem presidir a fixação e o desenvolvimento dos pressupostos da pena;

5. Numa perspectiva das Ciências Criminais, a política criminal funcionará como o elo de ligação entre a dogmática penal e a realidade, baseada nos subsídios trazidos pela criminologia;

6. No campo de uma Política Criminal para a chamada "questão das drogas", o modelo proibicionista-punitivo vem sendo adotado de forma hegemônica e, até bem pouco tempo, sem qualquer questionamento;

7. O modelo proibicionista-punitivo tem por fundamento dois princípios: um de ordem moral-religiosa, que obriga a abstinência como única meta, e outro de ordem higienista, que idealiza ser possível um mundo livre de drogas. Para atingir esses objetivos, impõe a proibição de qualquer modalidade de uso, comércio ou produção de drogas tidas como ilícitas, tipificando tais condutas como crime e prescrevendo penas privativas de liberdade ou, até mesmo, penas corporais;

8. O modelo proibicionista se internacionalizou através das chamadas ConvençõesIrmãs da ONU. A primeira, realizada em Nova Iorque em 1961, recuperou as determinações originárias da Liga das Nações, proscrevendo o ópio, a cannabis e a cocaína. A segunda, com sede em Viena em 1971, ratificou o ideário proibicionista frente aos movimentos contraculturais e proibiu as drogas sintéticas, especialmente o LSD. A terceira, novamente em Viena no ano de 1988, fortaleceu a estratégia repressiva como instrumento de combate ao crime organizado, definitivamente lançando o mundo na "war on drugs";

9. Essa Política Mundial foi ratificada em 1988 (UNGASS - 1998) ocasião que foi definida a meta de erradicar até 2008 a produção e o consumo de drogas ilícitas do planeta; 
10. Na última reunião, realizada em Viena em março de 2009, para avaliar o cumprimento das metas estabelecidas em 1998, a Comissão sobre Entorpecentes da ONU (CND) manteve a política punitiva-proibicionista e restabeleceu a meta de eliminar ou minimizar significativamente a produção e o uso de drogas ilícitas, agora com novo marco temporal, até o ano de 2019;

11. Contudo, ficou patente que não há mais unanimidade em torno da proposta proibicionista, nem no âmbito da própria Organização das Nações Unidas, uma vez que instâncias como a Organização Mundial de Saúde (OMS) e UNAIDS encamparam em seus programas e defenderam abertamente as chamadas estratégias de redução de danos;

12. Por outro lado, campo da Saúde Pública, a violência foi encampada como seu objeto, principalmente pelo crescimento epidêmico da mortalidade por causas externas, nas últimas décadas;

13. Ao assumir a violência como tema de sua preocupação, a Saúde Pública, se viu, necessariamente, na obrigação de examinar a conjugação dos vetores violência-drogas;

14. E, nesse passo, as estratégias de redução de danos mostraram-se como eficiente e adequada forma de intervenção para as ações políticas de saúde pública na intersecção dos fatores violência/ drogas;

15. Essa nova abordagem leva em consideração múltiplos fatores com relação ao fenômeno das drogas, tais como, sua complexidade, a diversidade das substâncias e seus usos e as particularidades sociais, culturais e psicológicas dos usuários, possibilitando uma melhor ponderação e individualização dos riscos e danos na cena de uso de drogas;

16. A retomada dessa concepção pela Saúde Pública foi motivada pelo protagonismo das pessoas que usam drogas, posto que, em 1984, a "Junkiebond", uma associação holandesa de usuários de drogas, preocupada com a crescente difusão da Hepatite $\mathrm{B}$ entre os usuários de drogas injetáveis iniciou, com o apoio do governo, o primeiro projeto de troca de agulhas e seringas usadas por novas (PTS);

17. Com o advento da epidemia de $A I D S$, as estratégias começaram a ser sistematizadas e a redução de danos se internacionalizou;

18. Inicialmente, a política de redução de danos foi definida como um conjunto de estratégias que visavam a diminuição dos agravos causados pelo uso de drogas, sem exigir a abstinência como meta ou condição para adesão aos serviços de atenção; 
19. Nessa medida, a redução de danos contrapõe-se ao modelo proibicionistapunitivo, que desconsidera a complexidade do fenômeno e tem a abstinência como meta única;

20. A expansão e diversificação dos programas de redução de danos e o aumento de pesquisas nas mais diversas áreas do conhecimento sobre o tema, teve como resultado a formulação e implementação de novas estratégias, visando a atenção a outros públicos e outras drogas, resultando na ampliação de seu campo de atuação;

21. Hoje é necessário rever e ampliar o seu conceito inicial para defini-la como uma política pragmática e humanitária que visa a melhora do quadro geral de vida do cidadão que usa drogas, nas suas mais variadas dimensões, sem a exigência da abstinência ou imposição de renúncia ao consumo dessas substâncias;

22. A nova política de saúde tem como fundamento a tolerância e adota uma postura dialógica, reconhecendo na pessoa que usa drogas um cidadão sujeito de direitos, protagonista das reivindicações de seu contexto social e corresponsável pela adoção das medidas necessárias para a melhoria de sua vida pessoal e relacional livrando-o, dessa forma, da rotulação sócio-cultural que lhe era imposta como estigma;

23. A Redução de Danos ganhou, na atualidade, reconhecimento internacional como uma alternativa viável ao modelo proibicionista e, no Brasil, ela foi legitimada com sua adoção como política pública de saúde para a área de drogas, tanto pelo Ministério da Saúde quanto pela própria Política Nacional sobre Drogas. Por outro lado, foi-lhe conferida a legalidade pela previsão de suas ações na própria Lei n 11.343/2006, a Lei de Drogas;

24. De qualquer sorte, para que se possa pretender sua transposição para outros campos de formulação política, para além da saúde pública, é necessário a identificação de suas características básicas, material e formalmente consideradas, para delas extrair um modelo abstrato que oriente os operadores, especialmente, para os fins desse trabalho, no campo da Política Criminal;

25. Na busca desse constructo podemos identificar, como elemento material ou fundamento ético, que a política de redução de danos se baseia no respeito à dignidade do usuário, na sua autonomia e liberdade individual e tem por meta a moderação; a Política Nacional sobre Drogas e a Lei 11.343/2006, corroboram esse entendimento; portanto, para que se tenha a intervenção como integrante do rol das estratégias de redução de danos, fazse necessário o substrato material traduzido no respeito à dignidade da pessoa humana; 
26. De outra parte, como elemento formal para a integralização do modelo, adota-se um critério objetivo, a vulnerabilidade, considerada como o conjunto de fatores de risco ou de perigo a pessoas, segmentos ou grupos sociais, decorrentes da seletividade das agências estatais de controle ou em razão da negação ou falta de garantia da efetivação de seus direitos fundamentais;

27. Nessa concepção, verificamos que a vulnerabilidade se apresenta numa tridimensionalidade, posto que é composta por três planos interdependentes: vulnerabilidade individual (psico-social), vulnerabilidade social (comunitária) e a vulnerabilidade institucional (frente às agências estatais, penais ou não);

28. A vulnerabilidade torna-se, nessa medida, um valioso instrumento para a definição de estratégias que visem a elaboração e o planejamento das ações políticas, tendo em conta que possibilita a identificação e análise das carências e necessidades da pessoa ou grupo social, dando maior objetividade e incrementando o pragmatismo das intervenções. A adoção da vulnerabilidade como critério objetivo de eleição das intervenções necessárias e adequadas para os casos concretos é, também, respaldada pela Política Nacional sobre Drogas e pela própria lei que rege a matéria;

29. A "Justiça Terapêutica", embora anunciada como uma alternativa mais tolerante, representa um reforço da política proibicionista, uma vez que amplia o seu arsenal de medidas e justifica a necessidade de criminalização da conduta do usuário como forma de fornecer ao Estado um instrumento supostamente apto a coagir os usuários a submeterem-se a tratamento sob a exigência de abstinência;

30. Ressalte-se, ainda, que Justiça terapêutica limita seus horizontes ao direito penal, desconsiderando a existência de medidas alternativas fora do campo punitivista e viola princípios ligados às liberdades públicas, notadamente a dignidade do usuário de drogas, que é visto como simplesmente como o alvo da tutela ou da repressão estatal;

31. Consagrando esse entendimento é de ser lembrado que a imposição de tratamento como pena, antecipada ou não, foi rejeitada no projeto de lei aprovado pelo Senado e, dessa forma, o tratamento compulsório carece de amparo legal, nos termos da Lei 11.343/2006;

32. Em contraposição, a Secretaria Nacional de Políticas sobre Drogas - SENAD, o Conselho Nacional de Justiça - CNJ e a Universidade de São Paulo, representada pelas Faculdades de Medicina e de Direito, elaboraram o programa designado "Integração de 
Competências no Desempenho da Atividade Judiciária com usuários e dependentes de Drogas" que visa a promoção de ações intersetoriais nas áreas jurídica, da educação, saúde e assistência social que apresentem medidas interdisciplinares para atenção ao fenômeno do uso de drogas em toda sua dimensão e diferentes interfaces;

34. Visando estabelecer um parâmetro para a aplicação da medida de advertência prevista no inciso I do artigo 28 da Lei de Drogas, e que vem sendo desvirtuada de suas finalidades, servindo, inclusive como base para a adoção de práticas como o tratamento compulsório, o programa de governo propõe que essa oportunidade seja convertida numa prática restaurativa. A pessoa será atendida por equipe multidisciplinar e receberá orientação sobre os diversos aspectos relacionados ao uso indevido de drogas, visando a compreensão do seu eventual comprometimento e as alternativas disponíveis para o estabelecimento de uma medida adequada e consensual para cada indivíduo;

35. Essa prática diante do usuário e do dependente de drogas, pretende criar uma oportunidade para que eles possam, a partir de um encontro dialógico, repensar sua relação com a droga, assim como as implicações desse comportamento nos diferentes domínios de sua vida;

36. Assim, o modelo proposto adota uma aproximação respeitosa com o atendido, dentro dos princípios preconizados pela Redução de Danos, possibilitando a busca consensual de alternativas para o tratamento, se necessário, e perspectivas concretas de reinserção social;

37. Nesse mesmo sentido, vale cotejar, ainda, as ações realizadas no Rio de Janeiro e São Paulo, com relação a usuários de crack, consistentes basicamente na internação compulsória mediante a adoção de medidas repressivas, com aquelas previstas no Plano Integrando de Enfrentamento ao Crack e outra Drogas, como os Consultórios de Rua e locais de acolhimento;

38. O Executivo Municipal Rio de Janeiro adotou como política o sistema de internação compulsória para crianças e adolescentes menores de idade usuários de crack em situação de rua, com base na sua resolução $n^{\circ}$ 20/2011 de 27/05/2011, intitulada Protocolo de Abordagem à Pessoa em Situação de Rua; o Governo paulista, por seu turno, deflagrou a "Operação Sufoco", intervenção meramente policial-militar, com nítida finalidade de higienização da região da "cracolândia", ambas as intervenções se caracterizam como nitidamente proibicionistas-punitivas; 
39. Novamente, como contraponto, as medidas propostas com fundamento nas estratégias de redução de danos são os Consultórios de Rua, que têm como finalidade o atendimento a essas pessoas na própria cena de uso e são compostos por equipes multidisciplinares, em geral, assistente social, psicólogo, médico, redutor de danos etc., que se deslocam em veículos adaptados para essa finalidade e os locais de acolhimento, como as Casas de Acolhimento Transitório, que funcionam como albergues 24 horas onde são oferecidos os serviços de atenção em saúde, dando maior institucionalidade e continuidade ao cuidado;

40. O confronto dessas medidas nos leva a concluir que impor a abstinência, pela via da repressão policial ou a internação involuntária indiscriminada, aprofunda a exclusão social e afronta a dignidade da pessoa humana. A complexidade da questão das drogas - e do crack, em especial - exige uma intervenção diversificada e contínua baseada na tolerância; o foco deve ser a saúde e a reinserção social;

41. Cabe ainda examinar, a possibilidade de adoção de medidas intermediárias, entre o proibicionismo e uma nova política de drogas, fora do campo penal e dentro do modelo teórico das estratégias de redução de danos, e a proposta de descriminalização ou adoção de um modelo mais tolerante com relação a algumas drogas, como a cannabis, se insere nesse contexto;

42. Hoje são inúmeros os estudos que apontam para a impropriedade da proscrição da cannabis e a criminalização das condutas a ela referidas, especialmente a de uso pessoal. Por outro lado, também são inúmeras as utilidades já comprovadas, notadamente suas aplicações terapêuticas. Finalmente, sua descriminalização representaria uma significativa perda para as organizações criminosas que monopolizam o comércio clandestino dessas substâncias, uma vez que a cannabis é, dentre todas, a mais difundida e a mais consumida em todo o mundo;

43. Há intensa mobilização político-social visando à descriminalização da cannabis, não só no Brasil como internacionalmente. Mesmo ex-chefes de governo, exdignitários e personalidades de expressão mundial e, até mesmo, chefes de estado, que há até pouco tempo eram responsáveis diretos pela implantação e condução do proibicionismo, reconhecem seu fracasso e proclamam a necessidade de revisão da política mundial; 
44. E, de fato, isso já vem ocorrendo em diversos países do mundo. Além da Holanda, sempre lembrada como exemplo de política alternativa, inúmeros outros países europeus, como a Espanha e Itália descriminalizaram o uso privado de drogas, e, especialmente, Portugal, que se tornou referência mundial, posto ser o único país que descriminalizou a conduta do consumo de qualquer psicotrópico, realizando seu controle pela via administrativa. Nas Américas, o Canadá, que sempre foi uma referência em políticas mais liberais, e, até mesmo, os Estados Unidos, passam hoje por intensa revisão sendo que dezesseis estados americanos e mais o Distrito de Columbia, onde está sediada a capital federal, já aprovaram a regulamentação do uso terapêutico da cannabis, que pode ser legalmente adquirida em estabelecimentos especialmente dedicados a esse comércio. A Argentina e a Colômbia descriminalizaram o uso privado, através de decisões de suas Cortes Constitucionais e o Uruguai admite o porte e uso privado de pequena quantidade de cannabis;

45. O debate que hoje se coloca é quanto a sustentabilidade do novo sistema. $\mathrm{O}$ problema decorre da ambiquidade do modelo. Nenhum país, por conta de seus compromissos internacionais, descriminalizou a produção, distribuição e o comércio de cannabis. Assim, o cidadão tem o direito ao consumo, nas mais variadas alternativas políticas, mas não tem como adquirir o produto de forma lícita. Inúmeras alternativas estão sendo discutidas, desde a solução da Califórnia, onde há uma permissão para que cada usuário medicinal possa produzir até 25 pés de cannabis para seu consumo pessoal e, a partir daí, foi criado um sistema de produção em cooperativas, até o modelo espanhol, também cooperativo, denominado Clubes Sociais de Cannabis (CSC), que se baseia na formação de associações de consumidores;

46. No Brasil, embora a questão da descriminalização da cannabis ainda esteja em debate, é possível um prognóstico otimista, com a necessidade de poucas alterações legais (quiçá apenas regulamentação administrativa), para a implementação de clubes de canabismo. A hipótese de autorização para o uso restrito a determinados locais e certos grupos de pessoas, restringe a propagação da conduta e melhora a eficácia do controle criminal, social e médico-sanitário;

47. Mas a atual referência em política de drogas é o modelo português, que adotou a estratégia de retirar a infração do controle penal e transformá-la num ilícito administrativo, ou como foi designada uma infração de mera ordenação social, ou contraordenações, que se situa no campo administrativo-penal. As drogas foram mantidas na 
ilegalidade, mas não na criminalidade. Esse novo enquadramento legal possibilitou a implantação de todo um conjunto de novas medidas com abordagens mais tolerantes, possibilitando o estabelecimento de vínculos com os usuários dessas substâncias e mantendo o controle formal sobre sua utilização, portanto, sem afrontar as Convenções Internacionais das quais Portugal também é signatário;

48. Como desfecho da hipótese inicialmente considerada no presente trabalho, vale recordar, a adoção do modelo da redução de danos no âmbito da Política Criminal, resta analisar as possibilidades de adoção do modelo para além da questão das drogas. Na atualidade, temas igualmente complexos permitem a mesma abordagem, são fenômenos sociais multifacetados, cuja conduta foi criminalizada e que, como na questão das drogas, são notadamente afetos à saúde pública;

49. Além disso, como na questão das drogas, eles enfeixam aspectos morais, éticos, biopsico-sociais, políticos, antropológicos, filosóficos, jurídicos e de saúde pública, o que implica na necessidade de uma abordagem interdisciplinar e que congregue os elementos propostos pelo modelo de redução de danos, isto é, situações de vulnerabilidade das quais decorrem ações práticas fundadas no respeito à dignidade humana;

50. O primeiro desses temas é o abortamento inseguro que, no Brasil, constitui uma das principais causas de morte materna, além de inúmeras morbidades e comorbidades dele decorrente. O principal paradigma é a política uruguaia, que recentemente estabeleceu um programa de redução de riscos e danos frente ao aborto inseguro; seguindo essa orientação, no ano de 2010 o Ministério da Saúde procedeu a uma revisão de sua norma técnica: “Atenção humanizada ao abortamento" (anexo 6), na qual estabelece os procedimentos necessários e devidos à mulher, tanto nos casos de aborto legal, quanto, na atenção e acolhimento nas fases pré e pós-abortamento de qualquer natureza;

51. Outro tema de igual complexidade que merece consideração é a terminalidade da vida. Com o espetacular avanço nos últimos tempos experimentado pelas ciências médicas acabamos por entender a morte como um fracasso terapêutico. Isso levou à adoção de condutas obstinadas diante de quadros terminais irreversíveis e que somente contribuem para o prolongamento de sofrimentos inúteis e dispendiosos para o enfermo e seus familiares, a distanásia. Por outro lado, debate-se também, a possibilidade de abreviar a vida em quadros de profundo sofrimento ou estados crônicos, embora não terminais, a eutanásia. Entre uma hipótese e outra, surge a ortotanásia, que se refere às atitudes que vão 
sendo assumidas na perspectiva do bem-estar do doente, quando as possibilidades de tratamento de uma enfermidade grave, incurável e em fase terminal, foram sendo progressivamente vencidas;

52. Os novos princípios deontológicos estabelecidos pelo Código de Ética Médica e pelas resoluções do Conselho Federal de Medicina, órgão que disciplina e fiscaliza a prática médica no Brasil, permitem ao médico limitar ou suspender procedimentos e tratamentos que prolonguem a vida do doente, em fase terminal, de enfermidade grave e incurável, respeitada sua vontade ou de seu representante legal, diante desse quadro, está excluído o dever de agir do facultativo, não podendo ser criminalizada sua conduta;

53. Ressalte-se que a prática médica continua a garantir todos os cuidados necessários para aliviar os sintomas que levam ao sofrimento, assegurada a assistência integral, o conforto físico, psíquico, social, espiritual, inclusive assegurando a ele o direito da alta hospitalar se assim o desejar;

54. Essa nova conformação ético-jurídica encontra seus fundamentos na Constituição da República Federativa do Brasil que consagra como seu princípio fundante a dignidade da pessoa humana e, embora não evite a morte do paciente, deve ser tomada como uma estratégia de redução de danos, uma vez que, considerando o estado de vulnerabilidade daquele indivíduo, a imposição de procedimentos dolorosos, dispendiosos e inúteis, apenas serviria para prolongar seu sofrimento e não para dar-lhe qualidade de vida diante do fato inexorável da existência humana, a sua finitude;

55. A Redução de Danos mostrou-se um modelo eficiente e paradigmático para a formulação de políticas públicas visando os fenômenos violência/crime/drogas, que requerem intervenções interdisciplinares e intersetoriais. É um instrumento apto a romper os limites de sua área original, a Saúde Pública, para ser utilizado em outros campos do conhecimento como, no caso em exame, a Política Criminal. Na área específica das Ciências Criminais, a Redução de Danos converge para a concretização de um Direito Penal minimalista e garantista, próprio de um Estado Social e Democrático de Direito e de uma sociedade tolerante e solidária. 


\section{REFERÊNCIAS BIBLIOGRÁFICAS}

AMÉRICA Latina quiere hablar de drogas. El Pais, 23.02.2012. Internacional. Disponível em: <http://internacional.elpais.com/internacional/2012/02/23/actualidad>. Acesso em: 23 fev. 2012.

ANDRADE, Tarcísio Matos de; FRIEDMAN, Samuel R. Princípios e práticas de redução de danos: interfaces e extensão a outros campos da intervenção e do saber. In: SILVEIRA, Dartiu, Xavier da; MOREIRA, Fernanda Gonçalves. Panorama atual de drogas $e$ dependências. São Paulo: Atheneu, 2006.

ARANA, Xabier; HUSAK, Douglas; SCHEERER, Sebastian (Coords.). Globalización y drogas: políticas sobre drogas, derechos humanos y reducción de riesgos. Madrid: Dykinson, 2003.

ARAÚJO, Marcelo Ribeiro; RIBEIRO, Maurides de Melo. Política mundial de drogas Ilícitas: uma reflexão histórica. In: SILVEIRA, Dartiu, Xavier da; MOREIRA, Fernanda Gonçalves. Panorama atual de drogas e dependências. São Paulo: Atheneu, 2006.

ARBEX José; TOGNOLI, Cláudio J. O século do crime. São Paulo: Boitempo, 1996.

ASSIS, Machado de. O alienista. In: 50 contos. Machado de Assis: seleção, introdução e notas John Gledson. São Paulo: Companhia das Letras, 2007.

AYOS, Emilio Jorge. Delito y pobreza: espacios de intersección entre la política criminal y la política social argentina en la primera década del nuevo siglo. São Paulo: IBCCrim, 2010 .

BARATTA, Alessandro. Criminologia crítica e crítica do direito penal: introdução à sociologia do direito penal. Tradução de Juarez Cirino dos Santos. 3. ed. Rio de Janeiro: Revan: Instituto Carioca de Criminologia, 2002.

Fundamentos ideológicos de la actual política criminal sobre drogas: reflexiones al rededor de la teoria del poder en Michel Foucault. In: RIPOLLÉS, José Luis, COPELLO, Patrícia Laurenzo. La actual política criminal sobre drogas: uma perspectiva comparada. Valencia: Tirant lo Blach, 1993. p. 19-36.

BARRETO, João de Deus Lacerda Menna. Estudo geral da nova lei de tóxicos. Rio de Janeiro: Freitas Bastos, 1988.

BASTOS, Francisco Inácio; MESQUITA, Fábio. Drogas e Aids: estratégias de redução de danos. São Paulo: Hucitec, 1994. 
BATISTA, Nilo. Política criminal com derramamento de sangue. Revista Brasileira de Ciências Criminais, São Paulo, n. 20, 1997.

BATISTA, Vera Malaguti. Difíceis ganhos fáceis: drogas e juventude pobre no Rio de Janeiro. Rio de Janeiro: Freitas Bastos, 2003.

- Drogas e criminalização da juventude pobre no Rio de Janeiro. Discursos Sediciosos: crime, direito e sociedade, Rio de Janeiro, v. 1, n. 2, p. 233-240, 1996.

BECKER, Howard Saul. Outsiders: estudos da sociologia do desvio. Rio de Janeiro: Jorge Zahar Ed., 2008.

BEWLEY-TAYLOR DR. Challenging the UN drug control conventions: problems and possibilities. Int J Drug Policy, v. 14, n. 2, p. 171-179, 2003.

BOBBIO, Norberto. Elogio da serenidade e outros escritos morais. São Paulo: UNESP, 2002.

A era dos direitos. Rio de Janeiro: Campus, 1992.

BODSTEIN, Regina Cele de A. Cidadania e modernidade: emergência da questão social na agenda pública. Cadernos de Saúde Publica. 1997, v. 13, n. 2. Disponível em: $<$ http://www.scielo.br>.

BRASIL. Conselho Federal de Medicina. Resolução n. 1.480, de 8 de agosto de 1997. Dispõe sobre os critérios de morte encefálica. Diário Oficial da União, Poder Executivo, Brasília, DF, n. 160, 21 ago. 1997. Seção 1, p.18.227-8. Disponível em: $<$ http://www.cremesp.org.br/library/modulos/legislacao/versao_impressao.php?id=3004>. Acesso em: 04 set. 2008.

Conselho Federal de Medicina. Resolução n. 1.826, de 24 de outubro de 2007. Dispõe sobre a legalidade e o caráter ético da suspensão dos procedimentos de suportes terapêuticos quando da determinação de morte encefálica de indivíduo não-doador. Diário Oficial da União, Poder Executivo, Brasília, DF, 06 dez. 2007. Seção I, p. 133. Disponível em:

<http://www.cremesp.org.br/library/modulos/legislacao/versao_impressao.php?id=7587>. Acesso em: 04 set. 2008.

Conselho Federal de Medicina. Resolução n. 1.931, de 17 de setembro de 2009. Aprova o Código de Ética Médica. Diário Oficial da União, Poder Executivo, Brasília, DF, de 24 set. 2009. Seção 1, p. 90-92. Disponível em: <http://www.abdir.com.br/legislacao/legislacao_abdir_24_9_09_1.pdf>. 
BRASIL. Lei n. 9.434, de 4 de fevereiro de 1997. Dispõe sobre a remoção de órgãos, tecidos e partes do corpo humano para fins de transplante e tratamento e dá outras providências. Diário Oficial da União, Poder Executivo, Brasília, DF, 05 fev. 1997. Seção 1. Disponível em: <http://www.planalto.gov.br/ccivil_03/Leis/L9434.htm>. Acesso em: 04 set. 2008.

BUCCI, Maria Paula Dallari. Direito administrativo e políticas públicas. São Paulo: Saraiva, 2000.

BUENO, Regina. Estratégias de redução de danos em Santos. In: BASTOS, Francisco I.; MESQUITA, Fábio; MARQUES, Luiz Fernando. Troca de seringas drogas e aids: ciência, debate e saúde pública. Brasília: Ministério da Saúde; 1998.

BUNING, Ernst. Vinte e cinco anos de redução de danos: a experiência de Amsterdã. In: SILVEIRA, Dartiu, Xavier da; MOREIRA, Fernanda Gonçalves. Panorama atual de drogas e dependências. São Paulo: Atheneu, 2006.

BURGIEMAN, D.R. O fim da guerra: a maconha e a criação de um novo sistema para lidar com as drogas. São Paulo: Leya, 2011.

CABALLERO, Francis, BISIOU, Yann. Droit de la drogue. 2. ed. Paris: Dalloz, 2000.

CANNABIS SOCIAL CLUBS, DRAFT TO THE PROJECT. Disponível em: $<$ www.encod.org/info/test $>$.

CANTO-SPERBER, M, org. Dicionário de ética e filosofia moral. São Leopoldo, RS: Ed. Unisinos; 2003. v. 1.

CARLINI, Elisaldo Araujo. A história da maconha no Brasil. In: CANNABIS sativa L. e substâncias canabinóides em medicina. São Paulo: CEBRID, 2005.

CARNEIRO, Henrique. Pequena Enciclopédia da história das drogas e bebidas: histórias e curiosidades sobre as mais variadas drogas e bebidas. Rio de Janeiro: Elsevier, 2005.

CARVALHO, Salo. A atual política brasileira de drogas: os efeitos do processo eleitoral de 1998. Revista Brasileira de Ciências Criminais, São Paulo, n. 34, 2001.

. A política criminal de drogas no Brasil (estudo criminológico e dogmático). 3. ed. reescr. ampl. e atual. Rio de Janeiro: Lúmen Júris, 2006.

CASHMAN, J. LSD. São Paulo: Perspectiva; 19. 
CAVALLARI, Celi Denise; SODELLI, Marcelo. Redução de danos e vulnerabilidades enquanto estratégia preventiva nas escolas. In: SEIBEL, Sérgio Dario (Org.). Dependência de drogas. São Paulo: Atheneu, 2010.

CHRISTIE, Nils. La industria del control del delito: la nueva forma del holocausto? Buenos Aires: Editores del Puerto, 1993.

COMISSÃO GLOBAL DE POLÍTICAS DE DROGAS. Disponível em: $<$ http://www.globalcommissionondrugs.org/>.

COMPARATO, Fábio Konder. A afirmação histórica dos direitos humanos. 4. ed. Sâo Paulo: Saraiva, 2005.

Fundamentos dos direitos humanos: a noção jurídica de fundamento e sua importância em matéria de direitos humanos. Revista Consulex, ano 4, n. 48, p. 52-61, dez. 2000.

COSTA, Leonardo Luiz de Figueiredo. Considerações sobre algumas inovações típicas da Lei $n^{o}$ 11.343/06. Disponível em: <www.ibccrim.org.br>. Acesso em: 12 nov. 2007.

CRIVES, Miranice Nunes dos Santos e DIMENSTEIN, Magda. Sentidos produzidos acerca do consumo de substâncias psicoativas por usuários de um programa público. Saúde Soc., v.12, no. 2, p.26-37, jul./dez. 2003.

DA ROS, Vera; DELBON, Fabiana; FERREIRA, Elza Maria Alves. Avaliação da Disponibilização de Kits de Redução de Danos. Saúde e Sociedade, v.15, n.1, p.37-48, jan./abr. 2006.

DEL OLMO, Rosa. A América Latina e sua criminologia. Rio de Janeiro: Revan: ICC, 2004.

. Las drogas y sus discursos. In: PIERANGELI, José Enrique (Coord.). Direito criminal. Belo Horizonte: Del Rey, 2004. v. 5.

A legislação no contexto das intervenções globais sobre drogas. Discursos Sediciosos: crime, direito e sociedade, Rio de Janeiro, v. 7, n. 12, 2. sem 2002.

DEL ROIO, José Luiz. Mundialização e criminalidade. In: RIBEIRO, Maurides M, SEIBEL, Sérgio D. (Orgs.). Drogas: hegemonia do cinismo. São Paulo: Fundação Memorial da América Latina; 1997.

DELMAS-MARTY, Mireille. Del derecho penal a la política criminal. Revista do Instituto Latinoamericano de las Naciones Unidas para la Prevención del Delito y el Tratamiento del Delincuente, n. 26, p. 70-82, 2002. 
DELMAS-MARTY, Mireille. Os grandes sistemas de política criminal. Barueri: Manole, 2004.

DIAS, João Carlos; PINTO, Izabel Marins. Substâncias psicoativas: classificações, mecanismos de ação e efeitos sobre o organismo. In: SILVEIRA, Dartiu, Xavier da; MOREIRA, Fernanda Gonçalves. Panorama atual de drogas e dependências. São Paulo: Atheneu, 2006.

DIAS, Jorge de Figueiredo. Questões fundamentais de direito penal revisitadas. São Paulo: Ed. Revista dos Tribunais, 1999.

As tendências recentes da política criminal e o novo Código Penal Português de 1982. Revista de Direito Penal e Criminologia, n. 34, 1982.

DOMANICO, Andrea. Craqueiros e cracados: bem vindo ao mundo dos nóias: estudo sobre a implementação de estratégias de redução de danos para usuários de crack nos cinco projetos-piloto do Brasil. 2006. Tese (Doutorado) - Universidade Federal da Bahia, Salvador, 2006.

DOMOSTAWSKI, Artur. Política da droga em Portugal: os benefícios da descriminalização do consumo de drogas. Global Drug Policy Program, Open Society Foundations, 2011.

DONEDA, Denise; GANDOLFI, Denise. O início da redução de danos no Brasil na perspectiva governamental: ação local com impacto nacional. In: SILVEIRA, Dartiu, Xavier da; MOREIRA, Fernanda Gonçalves. Panorama atual de drogas e dependências. São Paulo: Atheneu, 2006.

DÓRIA, Rodrigues. Os fumadores de maconha: efeitos e males do vício. In: BRASIL. Serviço Nacional de Educação Sanitária. Maconha: coletânea de trabalhos brasileiros. Rio de Janeiro: Ministério da Saúde, 1958.

ENGELS, Friedrich. Aditamento ao Livro Terceiro de "O Capital". In: MARX, Karl. $O$ capital: crítica da economia política. Rio de Janeiro: Civilização Brasileira, 1974. v. 6, Livro Terceiro.

ESCOHOTADO, Antonio. Historia general de las drogas. Madrid: Alianza Editorial, 1995.

O livro das drogas: usos e abusos, preconceitos e desafios. São Paulo: Dynamis Editorial, 1997. 
EUROPEAN MONITORING CENTER FOR DRUGS AND DRUG ADDICTION (EMCDDA), Statistical Bulletin 2010. Disponível em: $<$ http://www.emcdda.europa.eu/stats10>.

FAUSTO, Boris. Crime e cotidiano: a criminalidade em São Paulo (1880-1924). 2. ed. São Paulo: Ed. da Universidade de São Paulo, 2001.

FAZEY, CSJ. The Commission on Narcotic Drugs and the United Nations International Drug Control Programme: politics, policies and prospect for change. Int J Drug Policy, v. 14, n. 2, p. 155-169, 2003.

FERRAJOLI, Luigi. Más allá de la soberania y la cidadania: un constitucionalismo global. In: CARBONELL, Carbonell (Comp.). Teoria de la Constitución: ensayos escogidos. 4. ed. México: Editorial Porrúa y Universidad Nacional Autónoma de México, 2008. p. 397-410.

. A soberania no mundo moderno. São Paulo: Martins Fontes, 2002.

FIORE, Mauricio. Algumas reflexões a respeito dos discursos médicos sobre uso de "drogas". Disponível em: <www.neip.info>.

FORATTINI, P. Oswaldo. Epidemiologia geral. São Paulo: EDUSP, 1976.

FOUCAULT, Michel. História da loucura na Idade Clássica. São Paulo: Perspectiva, 2000.

FRANCO, Alberto Silva. Crimes hediondos: anotações sistemáticas à Lei 8.072/90. 4. ed. rev. atual. e ampl. São Paulo: Ed. Revista dos Tribunais, 2000.

; STOCCO, Rui (Coords.). Leis penais especiais e sua interpretação jurisprudencial. 7. ed. São Paulo: Ed. Revista dos Tribunais, 2001.

GARCÍA MÉNDEZ, Emilio. Del control como delito, al control del delito: notas para uma política criminal en la Argentina democrática. Doctrina Penal: teoría y práctica en las ciencias penales, n. 29/32, p. 379/387, 1985.

GARCÍA RAMÍREZ, Sérgio. Criminologia, dogmática y política penal: política criminal, derechos humanos y sistemas jurídicos en el Siglo XXI. Buenos Aires: Depalma, 2001.

GARCÍA-PABLOS DE MOLINA, Antonio. Tratado de criminología. 2. ed. Valencia: Tirant lo Blanch, 1999.

; GOMES, Luiz Flávio. Criminologia. 3. ed. São Paulo: Ed. Revista dos Tribunais, 2000. 
GOMES, Luiz Flávio; BIANCHINI, Alice; CUNHA, Rogério Sanches; OLIVEIRA, Willian Terra. Nova Lei de Drogas comentada artigo por artigo: Lei 11.343/2006, de 23.08.2006. São Paulo: Ed. Revista dos Tribunais, 2006.

GOMES, Mariângela Gama de Magalhães. Notas sobre a inidoneidade constitucional da criminalização do porte e do comércio de drogas. In: REALE JR., Miguel (Coord.). Drogas: aspectos penais e criminológicos. Rio de Janeiro: Forense, 2005.

GOMES, R. A violência social em questão: referenciais para um debate em saúde pública. Rev. Latinoam. Enfermagem, Ribeirão Preto, v. 5, n. 2, abr. 1997.

GRECO FILHO, Vicente. Tóxicos: prevenção-repressão: comentários à Lei $\mathrm{n}^{\mathbf{o}}$ 11.343/2006. 13. ed. rev. e ampl. São Paulo: Saraiva, 2009.

GREENWALD, G. Drug decriminalization in Portugal: lessons for creating fair and successful drug policies. The Cato Institute, 2009.

GUIMARÃES, Marcello Ovídio Lopes (Coord.). Nova Lei Antidrogas comentada. São Paulo: Quartier Latin, 2007.

HOSSNE, Willian Saad. Competência do médico. In: SEGRE, Marco; COHEN, Claudio (Orgs.). Bioética. São Paulo: EDUSP, 1995.

HOUAISS, Antonio; VILLAR, Mauro de Salles. Dicionário Houaiss da língua portuguesa. Rio de Janeiro: Objetiva, 2001.

HULSMAN, Louk. A política de drogas na Europa. Palestra ministrada no auditório do Instituto Brasileiro de Ciências Criminais (IBCCrim) (06 nov. 2003) [videocassete]. São Paulo: IBCCrim, 2003.

HUNGRIA, Nelson. Comentários ao Código Penal. Rio de Janeiro: Revista Forense, 1958. v. 9.

IGLÉSIAS, Francisco Assis. Sobre o vício da diamba. In: BRASIL. Serviço Nacional de Educação Sanitária. Maconha: coletânea de trabalhos brasileiros. Rio de Janeiro: Ministério da Saúde, 1958.

INFOPEN - Sistema Integrado de Informações Penitenciárias. Brasília: Ministério da Justiça, jun. 2001.

KARAM, Maria Lúcia. Aspectos jurídicos. In: SEIBEL, Sergio Dario; TOSCANO JR., Alfredo (Orgs.). Dependência de drogas. São Paulo: Ed. Atheneu, 2001. 
KARAM, Maria Lúcia. De crimes, penas e fantasias. Niterói: Luam Ed., 1991.

Drogas: processo legislativo. In: RIBEIRO, Maurides M, SEIBEL, Sérgio D. (Orgs.). Drogas: hegemonia do cinismo. São Paulo: Fundação Memorial da América Latina, 1997.

Legislação brasileira sobre drogas: história recente - a criminalização da diferença. In: ACSELRAD, Gilberta (Org.). Avessos do prazer: drogas, Aids e direitos humanos. Rio de Janeiro: Ed. FIOCRUZ, 2000.

Política de drogas: alternativas à repressão penal. Revista Brasileira de Ciências Criminais, São Paulo, n. 47, 2004.

KOPP, Pierre. A economia da droga. Bauru: EDUSC, 1998.

LABATE, Beatriz Caiuby et al. (Orgs.). Drogas e cultura: novas perspectivas. Salvador: EDUFBA, 2008.

LEARY, Timothy. Flashbacks - LSD: a experiência que abalou o sistema. São Paulo: Brasiliense, 1983.

LEONE, Salvino; PRIVITERA, Salvatore; CUNHA, Jorge Teixeira da (Coords.). Dicionário de bioética. Aparecida, SP: Ed. Santuário; 2001.

LOPES, Renato Malcher. Maconha, uma planta medicinal. Disponível em: $<$ http://sergyovitro.blogspot.com/2011/05/maconha-uma-planta-medicinal-renato.html>.

LUISI, Luiz. A legislação penal brasileira sobre entorpecentes: nota histórica. Fascículos de Ciências Penais, Porto Alegre, v. 3, n. 2, 1990.

MACHADO, Ana Regina; MIRANDA, Paulo Sérgio Carneiro. Fragmentos da história da atenção à saúde para usuários de álcool e outras drogas no Brasil: da Justiça à Saúde Pública. História, Ciências, Saúde-Manguinhos, Rio de Janeiro, v. 14, n. 3, jul./set. 2007.

MACRAE, Edward; SIMÕES, José Assis. Rodas de fumo: o uso da maconha entre camadas médias urbanas. Salvador: EDUFBA; CETAD/UFBA, 2000.

MAGNO, Levy Emanuel. Dos crimes e das penas (usuários e dependentes de drogas). In: GUIMARÃES, Marcello Ovídio Lopes (Coord.). Nova Lei Antidrogas comentada. São Paulo: Quartier Latin, 2007.

In: GUIMARÃES, Marcello Ovídio Lopes (Coord.). Nova lei antidrogas comentada. São Paulo: Quartier Latin, 2007. 
MARKS, John. Dosagem de manutenção de heroína e cocaína. In: RIBEIRO, Maurides M.; SEIBEL, Sérgio D. (Orgs.). Drogas: hegemonia do cinismo. São Paulo: Fundação Memorial da América Latina, 1997.

MARQUES, A. C. P. R. A avaliação do uso, abuso e dependência de álcool, tabaco e outras substâncias psicotrópicas e a intervenção breve. In: SEIBEL, Sérgio Dario (Org.). Dependência de drogas. São Paulo: Atheneu, 2010.

MELOSSI, Dario; PAVARINI, Massimo. Cárcere e fábrica: as origens do sistema penitenciário (séculos XVI-XIX). Rio de Janeiro: Revan: ICC, 2006.

MESQUITA, Fábio et. al. Aids ente usuários de drogas injetáveis na região metropolitana de Santos, na década de 1990. In: A CONTRIBUIÇÃO dos Estudos Multicêntricos frente à epidemia de HIV/Aids entre UDI no Brasil: 10 anos de pesquisa e redução de danos. Brasília: Ministério da Saúde, 2001.

MESQUITA NETO, Paulo de. Fazendo e medindo progresso em segurança pública. In: PRAIA Vermelha: estudos de política e teoria social. Universidade Federal do Rio de Janeiro. Programa de Pós Graduação em Serviço Social, Rio de Janeiro, 1997. v. 1, n. 1.

MILITELLO, Vicenzo. A descriminalização do uso de drogas: a experiência italiana. In: RIBEIRO, Maurides M.; SEIBEL, Sérgio D. (Orgs.). Drogas: hegemonia do cinismo. São Paulo: Fundação Memorial da América Latina, 1997.

MINAYO, Maria Cecília de Souza. A inclusão da violência na agenda da saúde: trajetória histórica. Ciênc. Saúde Coletiva, v. 11, p.1259-1267, 2006.

; DESLANDES, Suely Ferreira. A complexidade das relações entre drogas, álcool e violência. Cadernos de Saúde Pública, São Paulo, v. 14, n. 1, 1998. Disponível em: $<$ http://www.scielosp.org $>$.

; SOUZA, Edinilsa Ramos de. É possível prevenir a violência? Reflexões a partir do campo da saúde pública. Ciências e Saúde Coletiva, Rio de janeiro, v. 4, n. 1, p. 7-23, 1999.

MINGARDI, Guaracy. O Estado e o crime organizado. São Paulo: IBCCrim, 1998.

; GOULART, Sandra. As drogas ilícitas em São Paulo: o caso da Cracolândia. Revista do ILANUD, São Paulo, v. 15, 2001.

MISSE, Michel. Crime e violência no Brasil contemporâneo: estudos de sociologia do crime e da violência urbana. Rio de Janeiro: Lumen Juris, 2006. 
MISSE, Michel. Ligações perigosas: mercado informal ilegal, narcotráfico e violência no Rio de Janeiro. Contemporaneidade e Educação, v. 1, n. 2, p. 93-116, 1997.

O movimento: a constituição e reprodução das redes do mercado informal ilegal de drogas a varejo no Rio de Janeiro e seus efeitos de violência. In: BAPTISTA, Marcos; CRUZ, Marcelo Santos; MATIAS, Regina. Drogas e pós-modernidade: faces de um tema proscrito. Rio de Janeiro: UERJ/FAPERJ, 2003. v. 2, p. 147-156.

MODESTO, Luiz Sérgio. ONU: fundamentalismo puritano no mercado. In: RIBEIRO, Maurides M, SEIBEL, Sérgio D. (Orgs.). Drogas: hegemonia do cinismo. São Paulo: Fundação Memorial da América Latina, 1997.

MOREIRA, FG; HAIEK, R; SILVEIRA, DX. Redução de danos no Programa de Orientação e Atendimento a Dependentes - PROAD. Disponível em: $<$ www.plantandoapaz.org.br>.

MOTT, Luiz. A maconha na história do Brasil. In: HENMAN, Anthony, PESSOA JR., Osvaldo Diamba Sarabamba. Coletânea de textos brasileiros sobre a maconha. São Paulo: Ground, 1986.

MUSTO, David F. The american disease: origins of narcotic control. New York: Oxford University Press, 1987.

NATIONAL DRUG COURT INSTITUTE. Desenvolvimento e implementação de sistemas de Tribunais para dependentes químicos. Brasília: Embaixada dos Estados Unidos da América no Brasil, 1999. (Série Monografias 2).

OLIVEIRA, Reinaldo Ayer de. Eutanásia, distanásia e ortotanásia. Apostilas de Bioética. Bioética e Direito/USP, 2009. No prelo.

ORGANIZAÇÃO MUNDIAL DE SAÚDE. Saúde. Aborto sem riscos: guia técnico e políticas para sistemas de saúde. Genebra: OMS, 2003.

PASSETTI, Edson. Das fumeries ao narcotráfico. São Paulo: EDUC, 1991.

PEREIRA, José Carlos. Problema social e problema de Saúde Pública. In: TEMAS IMESC: sociedade, direito, saúde. São Paulo: IMESC, 1984.

PERES, M. F. T. Prevenção e controle: oposição ou complementaridade para a redução da violência. Sociedade Brasileira para o Progresso da Ciência, 2008. Disponível em: $<$ www.sbpcnet.org.br/>. 
PERRENOUD, L. O.; RIBEIRO, M. Histórico do consumo de crack no Brasil e no Mundo. In: RIBEIRO, M.; LARANJEIRA, R. (Orgs.). O tratamento do usuário de crack. 2. ed. Porto Alegre: Artmed, 2012.

PERTENCE, Sepúlveda. Natureza jurídica da posse de drogas para consumo próprio (art. 28, lei no 11.343/2006). Boletim IBCCrim, São Paulo, ano 15, n. 175, p. 1090, jun. 20.

PESSINI, L. Distanásia: até quando prolongar a vida. São Paulo: Loyola; 2001.

PINTO, R. Sócrates Gomes. Justiça restaurativa é possível no Brasil? In: SLAKMON, C., DE VITTO, R. e GOMES PINTO, R. S. (Orgs.). Justiça restaurativa. Brasília - DF: Ministério da Justiça e Programa das Nações Unidas para o Desenvolvimento - PNUD, 2005.

PIOVESAN, Flávia. Direitos humanos e o direito constitucional internacional. 5. ed. São Paulo: Max Limonad, 2002.

PIRES, Álvaro P. La "línea Marginot" en el derecho penal: la protección contra el crimen versus la protección contra el príncipe. Revista Brasileira de Ciências Criminais, São Paulo, n. 46, 2004.

PRESIDÊNCIA DA REPÚBLICA. Secretaria Especial dos Direitos Humanos. Comitê sobre Direitos Econômicos, Sociais e Culturais. Direitos Humanos, Econômicos, Sociais e Culturais. O cumprimento do Piedesc pelo Brasil. Plataforma Brasileira de Direitos Humanos, Econômicos, Sociais e Culturais - Plataforma DhESC Brasil. Brasília, 2003.

PRITTWITZ, Cornelius. O direito penal entre direito penal do risco e direito penal do inimigo: tendências atuais em direito penal e política criminal. Revista Brasileira de Ciências Criminais, São Paulo, n. 47, 2004.

QUEIROZ, Isabela Saraiva de. Adoção de ações de redução de danos direcionadas aos usuários de drogas: concepções e valores de equipes do Programa de Saúde da Família. Pesquisas e Práticas Psicossociais, São João del-Rei, v. 2, n. 1, mar./ago. 2007.

Os programas de redução de danos como espaços de exercício da cidadania dos usuários de drogas. Psicol. Cienc. Prof., Brasília, v. 21 n. 4, dez. 2001.

REALE JR., Miguel (Coord.). Drogas: aspectos penais e criminológicos. Rio de Janeiro: Forense, 2005.

REALI, Diva. Drogas, redução de danos e direitos humanos: transitando com Winnicott. Revista Urutágua - revista acadêmica multidisciplinar, maringá, n. 6, p. 2-3, 2004. 
REGHELIN, Elisangela Melo. Redução de danos: prevenção ou estímulo ao uso indevido de drogas injetáveis. São Paulo: Ed. Revista dos Tribunais, 2002.

RIBEIRO, L. A.; NAPPO, S. A.; SANCHEZ, Z. V. D. M. Aspectos socioculturais do consumo de crack. In: RIBEIRO, M.; LARANJEIRA, R. (Orgs.). O tratamento do usuário de crack. 2. ed. Porto Alegre: Artmed, 2012.

RIBEIRO, Maurides de Melo. Aspectos legais. In: SILVEIRA, Dartiu, Xavier da; MOREIRA, Fernanda Gonçalves. Panorama atual de drogas e dependências. São Paulo: Atheneu, 2006.

Políticas públicas e a questão das drogas: o impacto da política de redução de danos na legislação brasileira de drogas. 2007. Dissertação (Mestrado) - Faculdade de Direito, Universidade de São Paulo, São Paulo, 2007.

; ARAÚJO, Marcelo Ribeiro. Política mundial de drogas ilícitas: uma reflexão histórica. In: SILVEIRA, Dartiu, Xavier da; MOREIRA, Fernanda Gonçalves. Panorama atual de drogas e dependências. São Paulo: Atheneu, 2006.

; RODRIGUES, Luciana Boiteux de Figueiredo. Justiça terapêutica: redução de danos ou proibicionismo dissimulado? In: SEIBEL JR., Sergio Dario. Dependência de drogas: São Paulo: Ed. Atheneu. 2010.

; SEIBEL, Sérgio D. (Orgs.). Drogas: hegemonia do cinismo. São Paulo: Fundação Memorial da América Latina, 1997.

RODRIGUES, Luciana Boiteux de Figueiredo. Controle penal sobre as drogas ilícitas: impacto do proibicionismo no sistema penal e na sociedade. Tese (Doutorado) - Faculdade de Direito da Universidade de São Paulo, São Paulo, 2006.

; RIBEIRO, Maurides de Melo. Justiça terapêutica: redução de danos ou proibicionismo dissimulado? In: SEIBEL JR., Sergio Dario. Dependência de drogas: São Paulo: Ed. Atheneu. 2010.

ROSEN, G. Uma história da saúde pública. São Paulo: UNESP, 1994.

ROXIN, Claus. Derecho penal: parte general. Madrid: Civitas, 1997.t. 1.

Dogmática penal y política criminal. Trad. Manuel A. Abanto Vasquez. Lima: EDERSA, 1998.

La evolución de la politica criminal, el derecho penal y el processo penal. Valencia: Tirant lo Blanch, 2000. 
ROXIN, Claus. Política criminal y estructura del delito: elementos del delito em base a la política criminal. Trad. Juan Bustos Ramírez y Hernán Hormazábal Malarée. Barcelona: PPU, 1992.

Sobre a fundamentação político-criminal do sistema jurídico-penal. Revista Brasileira de Ciências Criminais, São Paulo, n. 35, jul./set. 2001.

SÃO PAULO (Estado). Lei n. 10.241, de 17 de março de 1999. Dispõe sobre os direitos dos usuários dos serviços e das ações de saúde no Estado e dá outras providências. Diário Oficial do Estado, Poder Executivo, São Paulo, n. 51, de 18 mar. 1999. Seção 1, p. 1. Disponível em: <http://www.cremesp.org.br/library/modulos/legislacao/versao_impressao.php?id=3080>. Acesso em: 04 set. 2008.

SEIBEL, Sergio Dario (Org.). Dependência de drogas. São Paulo: Ed. Atheneu, 2010.

SHECAIRA, Sérgio Salomão. Criminologia. 2. ed. rev., atual. e ampl. São Paulo: Ed. Revista dos Tribunais, 2008.

SHEERER, Sebastian, Dominação Ideológica versus Lazer Psicotrópico. In: RIBEIRO, Maurides M, SEIBEL, Sérgio D. (Orgs.). Drogas: hegemonia do cinismo. São Paulo: Fundação Memorial da América Latina, 1997.

SILVA, Milton Severiano da. Se Liga! O livro das drogas. Rio de Janeiro: Record, 1997.

SILVA, Pablo Rodrigo Alflen da. Aspectos críticos do direito penal na sociedade do risco. Revista Brasileira de Ciências Criminais, São Paulo, n. 46, 2004.

SILVEIRA, Dartiu, Xavier da; MOREIRA, Fernanda Gonçalves. Panorama atual de drogas e dependências. São Paulo: Atheneu, 2006.

SODELLI, Marcelo. Uso de drogas e prevenção: da desconstrução da postura proibicionista às ações redutoras de vulnerabilidade. São Paulo: Iglu, 2010.

SOUZA, Marcelo Lopes de. Fobópole: o medo generalizado e a militarização da questão urbana. Rio de Janeiro: Bertrand Brasil, 2008.

STUDART, Vivian Ferraz. Um estudo da experiência de implementação do Programa de Redução de Danos ao Uso de Drogas do Distrito Federal. Brasília, 2007. Dissertação (Mestrado - Programa de Pós-Graduação em Saúde Pública) - FIOCRUZ, Brasília, 2007.

TIMERMAN A, CÉSAR, L. A. M.; TIMERMAN, S, VIEIRA S. R. R. (Coords.). Consenso Nacional de Ressuscitação Cardiorrespiratória. Arquivos Brasileiros de Cardiologia, São Paulo, v. 66, n. 6, p. 375-402, 1996. 
TORRES, José Henrique Rodrigues. Aborto inseguro: é necessário reduzir riscos. Revista Brasileira de Ciências Criminais, São Paulo, n. 68, 2007.

TOUZÉ, Graciela Dora; GOLTZMAN, Paula Marcela. Aportes para uma nueva política de drogas: V y VI Conferencia Nacional sobre Políticas de Drogas. Buenos Aires: Intercambios Asociación Civil; Facultad de Ciencias Sociales, Universidad de Buenos Aires, 2010.

TRIGUEIROS, Daniela Piconez; HAIEK, Rita de Cássia. Estratégias de redução de danos entre usuários de drogas injetáveis. In: SILVEIRA, Dartiu, Xavier da; MOREIRA, Fernanda Gonçalves. Panorama atual de drogas e dependências. São Paulo: Atheneu, 2006.

TRIVIÑOS, Augusto N. S. Introdução à pesquisa em ciências sociais: a pesquisa qualitativa em educação. São Paulo: Atlas, 1987.

UNITED NATIONS GENERAL ASSEMBLY. Programme of Action of the International Conference on Population and Developement. New York: United Nations, 1994.

UNITED NATIONS OFFICE ON DRUGS AND CRIME (UNODC). Commission on Narcotic Drugs documents. Vienna: UNODC. Disponível em: <http://www.unodc.org>.

- Treaty and Legal Affairs [online]. Vienna: UNODC. Disponível em: $<$ http://www.unodc.org $>$.

UNITED NATIONS ORGANIZATION (UNO). General Assembly Twentieth Special Session (UNGASS). New York: UNO; 1999. Disponível em: $<$ http://www.un.org/ga/20special >.

UPRIMNY, Rodrigo. Narcotráfico e poder. In: RIBEIRO, Maurides M, Seibel Sérgio D. (Orgs.). Drogas: hegemonia do cinismo. São Paulo: Fundação Memorial da América Latina, 1997.

VESTER, Annette. Os programas de troca de seringas em Amsterdã. In: BASTOS, Francisco I.; MESQUITA, Fábio; MARQUES, Luiz F. Troca de seringas: ciência, debate e saúde pública. Brasília: Ministério da Saúde, 1998.

2010 .

Cannabis medicinal: introdução ao cultivo indoor. Salvador: Edição do Autor,

Da diamba à maconha: usos e abusos da Cannabis sativa e da sua proibição no Brasil. Disponível em: <http://www.koinonia.org.br/bdv/detalhes.asp?cod_artigo=304>. 
VIDAL, Sérgio. A regulamentação do cultivo da maconha para consumo próprio: uma proposta de redução de danos. In: NERY FILHO, Antonio et al. (Orgs.). Toxicomanias: incidências clínicas e socioantropológicas. Salvador: EDUFBA: CETAD, 2009. .

WEIGERT, Mariana de Assis Brasil. Uso de drogas e sistema penal: entre o proibicionismo e a redução de danos. Rio de Janeiro: Ed. Lumen Juris, 2010.

WODAK, Alex. Redução de danos e programas de trocas de seringas. In: BASTOS, Francisco I.; MESQUITA, Fábio; MARQUES, Luiz Fernando. Troca de seringas drogas e aids: ciência, debate e saúde pública. Brasília: Ministério da Saúde, 1998.

ZAFFARONI, Eugenio Raúl. En busca de las penas perdidas: deslegitimacion y dogmática jurídico-penal. 2. reimpr. Buenos Aires: EDIAR, 1998.

En busca de las penas perdidas: a perda de legitimidade do sistema penal. Rio de Janeiro: Revan, 1991.

La legislación "Antidroga” Latino Americana: sus componentes de derecho penal autoritario. Fascículos de Ciências Penais, Porto Alegre, n. esp., Drogas Abordagem Interdisciplinar, 1990.

ZIMMER, L.; MORGAN, J. P. Maconha: mitos e fatos - uma revisão das provas científicas. Rio de Janeiro: Psicotropicus, 2010. 


\section{ANEXOS}




\section{$\underline{\text { ANEXO } 1}$}

Edição Número 127 de 05/07/2005

Ministério da Saúde Gabinete do Ministro

\section{PORTARIA N 1.059, DE 4 DE JULHO DE 2005}

Destina incentivo financeiro para o fomento de ações de redução de danos em Centros de Atenção Psicossocial para o Álcool e outras Drogas - CAPSad - e dá outras providências.

O MINISTRO DE ESTADO DA SAÚDE, no uso de suas atribuições, e

Considerando a Lei $\mathrm{n}^{\circ} 10.216$, de 6 de abril de 2001, que dispõe sobre a proteção e os direitos das pessoas portadoras de transtornos mentais e redireciona o modelo assistencial em saúde mental;

Considerando que as estratégias de redução de danos fazem parte da Política Nacional Antidrogas (2003);

Considerando a Portaria $\mathrm{n}^{\circ}$ 336/GM, de 19 de fevereiro de 2002, que define as normas e diretrizes para a organização dos serviços que prestam assistência em saúde mental;

Considerando a necessidade de acelerar a estruturação e a consolidação da rede extrahospitalar de atenção à Saúde Mental em todas as unidades da federação; e

Considerando a necessidade de articulação no território das ações de redução de danos à saúde dirigidas a usuários de álcool e outras drogas com a rede de atenção em saúde mental, resolve:

Art. $1^{\circ}$ Destinar ao Distrito Federal, aos estados, e aos municípios, incentivo financeiro, para o fomento de ações de redução de danos nos Centros de Atenção Psicossocial para o Álcool e outras Drogas - CAPSad cadastrados e em funcionamento, observadas as diretrizes da Portaria n ${ }^{\circ}$ 336/GM, de 19 de fevereiro de 2002.

Art. $2^{\circ}$ Definir que, no âmbito desta Portaria, entende-se ações de redução de danos como intervenções de saúde pública que visam prevenir as conseqüências negativas do uso de álcool e outras drogas, tais como:

I - ampliação do acesso aos serviços de saúde, especialmente dos usuários que não têm contato com o sistema de saúde, por meio de trabalho de campo;

II - distribuição de insumos (seringas, agulhas, cachimbos) para prevenir a infecção dos vírus HIV e Hepatites B e C entre usuários de drogas;

III - elaboração e distribuição de materiais educativos para usuários de álcool e outras drogas informando sobre formas mais seguras do uso de álcool e outras drogas e sobre as consequiências negativas do uso de substâncias psicoativas; 
IV - ampliação do número de unidades de tratamento para o uso nocivo de álcool e outras drogas;

V - outras medidas de apoio e orientação, com o objetivo de modificar hábitos de consumo e reforçar o auto-controle.

Art. $3^{\circ}$ Determinar que as solicitações de incentivo para o fomento das ações de redução de danos sejam apresentadas ao Ministério da Saúde, com cópia para a respectiva Secretaria de Estado da Saúde, devendo ser instruídas com os seguintes documentos:

I - ofício do gestor solicitando o incentivo financeiro;

II - descrição das estratégias comunitárias de redução de danos vinculadas ao CAPSad, com duração mínima de 12 meses e definição da área de abrangência e o número de usuários de álcool e outras drogas previstos a serem acessadas;

III - relação dos agentes redutores de danos que estarão vinculados ao serviço, acompanhada de dados de identificação;

IV - termo de compromisso do gestor local, assegurando o início das ações em até 3 (três) meses após o recebimento do incentivo financeiro de que trata esta Portaria; e

V - proposta técnica de aplicação dos recursos.

Art. $4^{\circ}$ Estabelecer como condições indispensáveis para que os municípios ou estados e Distrito Federal habilitem-se ao recebimento do incentivo definido nesta Portaria:

I - existência de CAPSad cadastrado no município a ser beneficiado;

II - população do município superior a 100.000 habitantes.

Parágrafo único. No caso de Estados e do Distrito Federal, o gestor deverá apresentar proposta técnica especificando a região de abrangência do programa de redução de danos a ser apoiado.

Art. $5^{\circ}$ Estabelecer que o Fundo Nacional de Saúde adote as medidas necessárias para a devolução dos recursos recebidos, caso haja o descumprimento do prazo de início das ações definido nesta Portaria.

Art. $6^{\circ}$ Definir que o incentivo de que trata o artigo $1^{\circ}$ desta Portaria seja da ordem de $\mathrm{R} \$ 50.000,00$ (cinqüenta mil reais) anuais.

$\S 1^{\circ} \mathrm{O}$ incentivo será transferido, em parcela única anual, aos respectivos fundos, dos Estados, Municípios e do Distrito Federal, sem onerar os respectivos tetos da assistência de média e alta complexidade.

$\S 2^{\circ} \mathrm{O}$ incentivo de que trata esta Portaria destina-se a apoiar financeiramente apenas os serviços de natureza jurídica pública. 
Art. $7^{\circ}$ Estabelecer que os recursos orçamentários, objeto desta Portaria, corram por conta do orçamento do Ministério da Saúde, devendo onerar o programa de trabalho 10.302.1312.8529 - Serviços Extra-Hospitalares de Atenção aos Portadores de Transtornos Mentais e Transtornos Decorrentes do Uso de Álcool e outras Drogas.

Art. $8^{\circ}$ Esta Portaria entra em vigor na data de sua publicação.

\section{HUMBERTO COSTA}




\title{
ANEXO 2
}

\section{Política Nacional Sobre Drogas}

\author{
GABINETE DE SEGURANÇA INSTITUCIONAL
}

CONSELHO NACIONAL ANTIDROGAS

RESOLUÇÃO Nº3/GSIPR/CH/CONAD, DE 27 DE OUTUBRO DE 2005

Aprova a Política Nacional Sobre Drogas

O PRESIDENTE DO CONSELHO NACIONAL ANTIDROGAS - CONAD, no uso de suas atribuições, tendo em vista o disposto nos arts. $5^{\circ}$ do Decreto $n^{\circ} 3.696$, de 21 de dezembro de 2000 e 18 do Regimento Interno e em decorrência do processo que realinhou a Política Nacional Antidrogas até então vigente,

RESOLVE:

Art. $1^{\circ}$ Fica aprovada a Política Nacional Sobre Drogas, na forma do anexo a esta resolução, tendo em vista deliberação do Conselho Nacional Antidrogas em reunião de 23 de maio de 2005.

Art. $2^{\circ}$ Esta Resolução entra em vigor na data de sua publicação.

JORGE ARMANDO FELIX

POLÍTICA NACIONAL SOBRE DROGAS

Brasília 2005

\section{PRESSUPOSTOS DA POLÍTICA NACIONAL SOBRE DROGAS}

- Buscar, incessantemente, atingir o ideal de construção de uma sociedade protegida do uso de drogas ilícitas e do uso indevido de drogas lícitas.

- Reconhecer as diferenças entre o usuário, a pessoa em uso indevido, o dependente e o traficante de drogas, tratando-os de forma diferenciada.

- Tratar de forma igualitária, sem discriminação, as pessoas usuárias ou dependentes de drogas lícitas ou ilícitas.

- Buscar a conscientização do usuário e da sociedade em geral de que o uso de drogas ilícitas alimenta as atividades e organizações criminosas que têm, no narcotráfico, sua principal fonte de recursos financeiros.

- Garantir o direito de receber tratamento adequado a toda pessoa com problemas decorrentes do uso indevido de drogas.

- Priorizar a prevenção do uso indevido de drogas, por ser a intervenção mais eficaz e de menor custo para a sociedade. 
- Não confundir as estratégias de redução de danos como incentivo ao uso indevido de drogas, pois se trata de uma estratégia de prevenção.

- Intensificar, de forma ampla, a cooperação nacional e internacional, participando de fóruns sobre drogas, bem como estreitando as relações de colaboração multilateral, respeitando a soberania nacional.

- Reconhecer a corrupção e a lavagem de dinheiro como as principais vulnerabilidades a serem alvo das ações repressivas, visando ao desmantelamento do crime organizado, em particular do relacionado com as drogas.

- Elaborar planejamento que permita a realização de ações coordenadas dos diversos órgãos envolvidos no problema, a fim de impedir a utilização do território nacional para o cultivo, a produção, a armazenagem, o trânsito e o tráfico de drogas ilícitas.

- Garantir, incentivar e articular, por intermédio do Conselho Nacional Antidrogas - CONAD, o desenvolvimento de estratégias de planejamento e avaliação nas políticas de educação, assistência social, saúde e segurança pública, em todos os campos relacionados às drogas.

- Garantir ações para reduzir a oferta de drogas, por intermédio de atuação coordenada e integrada dos órgãos responsáveis pela persecução criminal, em níveis federal e estadual, visando realizar ações repressivas e processos criminais contra os responsáveis pela produção e tráfico de substâncias proscritas, de acordo com o previsto na legislação.

- Fundamentar, no princípio da responsabilidade compartilhada, a coordenação de esforços entre os diversos segmentos do governo e da sociedade, em todos os níveis, buscando efetividade e sinergia no resultado das ações, no sentido de obter redução da oferta e do consumo de drogas, do custo social a elas relacionado e das conseqüências adversas do uso e do tráfico de drogas ilícitas e do uso indevido de drogas lícitas.

- Garantir a implantação, efetivação e melhoria dos programas, ações e atividades de redução da demanda (prevenção, tratamento, recuperação e reinserção social) e redução de danos, levando em consideração os indicadores de qualidade de vida, respeitando potencialidades e princípios éticos.

- Incentivar, orientar e propor o aperfeiçoamento da legislação para garantir a implementação e a fiscalização das ações decorrentes desta política.

- Pesquisar, experimentar e implementar novos programas, projetos e ações, de forma pragmática e sem preconceitos, visando à prevenção, tratamento, reinserção psicossocial, redução da demanda, oferta e danos com fundamento em resultados científicos comprovados.

- Garantir que o Sistema Nacional Antidrogas - SISNAD seja implementado por meio dos Conselhos em todos os níveis de governo e que esses possuam caráter deliberativo, articulador, normativo e consultivo, assegurando a composição paritária entre sociedade civil e governo.

- Reconhecer o uso irracional das drogas lícitas como fator importante na indução de dependência, devendo, por esse motivo, ser objeto de um adequado controle social, especialmente nos aspectos relacionados à propaganda, comercialização e acessibilidade de populações vulneráveis, tais como crianças e adolescentes.

- Garantir dotações orçamentárias permanentes para o Fundo Nacional Antidrogas - FUNAD, a fim de implementar ações propostas pela Política Nacional sobre Drogas, com ênfase para aquelas relacionadas aos capítulos da PNAD: prevenção, tratamento e reinserção social, redução de danos, redução da oferta, estudos e pesquisas. 


\section{OBJETIVOS DA POLÍTICA NACIONAL SOBRE DROGAS}

- Conscientizar a sociedade brasileira sobre os prejuízos sociais e as implicações negativas representadas pelo uso indevido de drogas e suas consequiências.

- Educar, informar, capacitar e formar pessoas em todos os segmentos sociais para a ação efetiva e eficaz de redução da demanda, da oferta e de danos, fundamentada em conhecimentos científicos validados e experiências bem-sucedidas, adequadas à nossa realidade.

- Conhecer, sistematizar e divulgar as iniciativas, ações e campanhas de prevenção do uso indevido de drogas em uma rede operativa, com a finalidade de ampliar sua abrangência e eficácia.

- Implantar e implementar rede de assistência integrada, pública e privada, intersetorial, para pessoas com transtornos decorrentes do consumo de substâncias psicoativas, fundamentada em conhecimento validado, de acordo com a normatização funcional mínima, integrando os esforços desenvolvidos no tratamento.

- Avaliar e acompanhar sistematicamente os diferentes tratamentos e iniciativas terapêuticas, fundamentados em diversos modelos, com a finalidade de promover aqueles que obtiverem resultados favoráveis.

- Reduzir as consequiências sociais e de saúde decorrentes do uso indevido de drogas para a pessoa, a comunidade e a sociedade.

- Difundir o conhecimento sobre os crimes, delitos e infrações relacionados às drogas ilícitas e lícitas, prevenindo-os e coibindo-os por meio da implementação e efetivação de políticas públicas para a melhoria da qualidade de vida do cidadão.

- Combater o tráfico de drogas e os crimes conexos, em todo território nacional, dando ênfase às áreas de fronteiras terrestres, aéreas e marítimas, por meio do desenvolvimento e implementação de programas socioeducativos específicos, multilaterais, que busquem a promoção da saúde e a reparação dos danos causados à sociedade.

- Assegurar, de forma contínua e permanente, o combate à corrupção e à lavagem de dinheiro, como forma de estrangular o fluxo lucrativo desse tipo de atividade ilegal, que diz respeito ao tráfico de drogas.

- Manter e atualizar, de forma contínua, o Observatório Brasileiro de Informações sobre Drogas - OBID, para fundamentar, dentro de outras finalidades, o desenvolvimento de programas e intervenções dirigidas à redução de demanda (prevenção, tratamento e reinserção psicossocial), redução de danos e de oferta de drogas, resguardados o sigilo, a confidencialidade e seguidos os procedimentos éticos de pesquisa e armazenamento de dados.

- Garantir rigor metodológico às atividades de redução da demanda, oferta e danos, por meio da promoção de levantamentos e pesquisas sistemáticas, avaliados por órgão de referência da comunidade científica.

- Garantir a realização de estudos e pesquisas visando à inovação dos métodos e programas de redução da demanda, da oferta e dos danos sociais e à saúde.

- Instituir, em todos os níveis de governo, com rigor metodológico, sistema de planejamento, acompanhamento e avaliação das ações de redução da demanda, da oferta e dos danos sociais e à saúde. 
- Assegurar, em todos os níveis de governo, dotação orçamentária e efetivo controle social sobre os gastos e ações preconizadas nesta política, em todas as etapas de sua implementação, contemplando os preceitos estabelecidos pelo CONAD, incentivando a participação de toda a sociedade.

\section{PREVENÇÃO}

\subsection{Orientação geral}

1.1.1 A efetiva prevenção é fruto do comprometimento, da cooperação e da parceria entre os diferentes segmentos da sociedade brasileira e dos órgãos governamentais, federal, estadual e municipal, fundamentada na filosofia da "Responsabilidade Compartilhada", com a construção de redes sociais que visem à melhoria das condições de vida e promoção geral da saúde.

1.1.2 A execução desta política, no campo da prevenção deve ser descentralizada nos municípios, com o apoio dos Conselhos Estaduais de políticas públicas sobre drogas e da sociedade civil organizada, adequada às peculiaridades locais e priorizando as comunidades mais vulneráveis, identificadas por um diagnóstico. Para tanto, os municípios devem ser incentivados a instituir, fortalecer e divulgar o seu Conselho Municipal sobre Drogas.

1.1.3 As ações preventivas devem ser pautadas em princípios éticos e pluralidade cultural, orientando-se para a promoção de valores voltados à saúde física e mental, individual e coletiva, ao bem-estar, à integração socioeconômica e a valorização das relações familiares, considerando seus diferentes modelos.

1.1.4 As ações preventivas devem ser planejadas e direcionadas ao desenvolvimento humano, o incentivo à educação para a vida saudável, acesso aos bens culturais, incluindo a prática de esportes, cultura, lazer, a socialização do conhecimento sobre drogas, com embasamento científico, o fomento do protagonismo juvenil, da participação da família, da escola e da sociedade na multiplicação dessas ações.

1.1.5 As mensagens utilizadas em campanhas e programas educacionais e preventivos devem ser claras, atualizadas e fundamentadas cientificamente, considerando as especificidades do público-alvo, as diversidades culturais, a vulnerabilidade, respeitando as diferenças de gênero, raça e etnia.

\subsection{Diretrizes}

1.2.1 Garantir aos pais e/ou responsáveis, representantes de entidades governamentais e nãogovernamentais, iniciativa privada, educadores, religiosos, líderes estudantis e comunitários, conselheiros estaduais e municipais e outros atores sociais, capacitação continuada sobre prevenção do uso indevido de drogas lícitas e ilícitas, objetivando engajamento no apoio às atividades preventivas com base na filosofia da responsabilidade compartilhada.

1.2.2 Dirigir as ações de educação preventiva, de forma continuada, com foco no indivíduo e seu contexto sociocultural, buscando desestimular o uso inicial de drogas, incentivar a diminuição do consumo e diminuir os riscos e danos associados ao seu uso indevido.

1.2.3 Promover, estimular e apoiar a capacitação continuada, o trabalho interdisciplinar e multiprofissional, com a participação de todos os atores sociais envolvidos no processo, possibilitando que esses se tornem multiplicadores, com o objetivo de ampliar, articular e 
fortalecer as redes sociais, visando ao desenvolvimento

integrado de programas de promoção geral à saúde e de prevenção.

1.2.4 Manter, atualizar e divulgar um sistema de informações de prevenção sobre o uso indevido de drogas, integrado, amplo e interligado ao OBID, acessível a toda a sociedade, que favoreça a formulação e implementação de ações de prevenção, incluindo mapeamento e divulgação de "boas práticas" existentes no Brasil e em outros países.

1.2.5 Incluir processo de avaliação permanente das ações de prevenção realizadas pelos Governos, Federal, Estaduais, Municipais, observando-se as especificidades regionais.

1.2.6 Fundamentar as campanhas e programas de prevenção em pesquisas e levantamentos sobre o uso de drogas e suas consequiências, de acordo com a população-alvo, respeitadas as características regionais e as peculiaridades dos diversos segmentos populacionais, especialmente nos aspectos de gênero e cultura.

1.2.7 Propor a inclusão, na educação básica e superior, de conteúdos relativos à prevenção do uso indevido de drogas.

1.2.8 Priorizar ações interdisciplinares e contínuas, de caráter preventivo e educativo na elaboração de programas de saúde para o trabalhador e seus familiares, oportunizando a prevenção do uso indevido de drogas no ambiente de trabalho em todos os turnos, visando à melhoria da qualidade de vida, baseadas no

processo da responsabilidade compartilhada, tanto do empregado como do empregador.

1.2.9 Recomendar a criação de mecanismos de incentivo para que empresas e instituições desenvolvam ações de caráter preventivo e educativo sobre drogas.

\section{TRATAMENTO, RECUPERAÇÃO E REINSERÇÃO SOCIAL}

\subsection{Orientação Geral}

2.1.1 O Estado deve estimular, garantir e promover ações para que a sociedade (incluindo os usuários, dependentes, familiares e populações específicas), possa assumir com responsabilidade ética, o tratamento, a recuperação e a reinserção social, apoiada técnica e financeiramente, de forma descentralizada, pelos órgãos governamentais, nos níveis municipal, estadual e federal, pelas organizações não-governamentais e entidades privadas.

2.1.2 $\mathrm{O}$ acesso às diferentes modalidades de tratamento e recuperação, reinserção social e ocupacional deve ser identificado, qualificado e garantido como um processo contínuo de esforços disponibilizados, de forma permanente, para os usuários, dependentes e seus familiares, com investimento técnico e financeiro de forma descentralizada.

2.1.3 As ações de tratamento, recuperação, reinserção social e ocupacional devem ser vinculadas a pesquisas científicas, avaliando-as e incentivando-as e multiplicando aquelas que tenham obtido resultados mais efetivos, com garantia de alocação de recursos técnicos e financeiros, para a realização dessas práticas e pesquisas, promovendo o aperfeiçoamento das demais.

2.1.4 Na etapa da recuperação, deve-se destacar e promover ações de reinserção familiar, social e ocupacional, em razão de sua constituição como instrumento capaz de romper o ciclo 
consumo/tratamento, para grande parte dos envolvidos, por meio de parcerias e convênios com órgãos governamentais e organizações não-governamentais, assegurando a distribuição descentralizada de recursos técnicos e financeiros.

2.1.5 No Orçamento Geral da União devem ser previstas dotações orçamentárias, em todos os ministérios responsáveis pelas ações da Política Nacional sobre Drogas, que serão distribuídas de forma descentralizada, com base em avaliação das necessidades específicas para a área de tratamento, recuperação, redução de danos, reinserção social e ocupacional, estimulando o controle social e a responsabilidade compartilhada entre governo e sociedade

2.1.6 A capacitação continuada, avaliada e atualizada de todos os setores governamentais e nãogovernamentais envolvidos com tratamento, recuperação, redução de danos, reinserção social e ocupacional dos usuários, dependentes e seus familiares deve ser garantida, inclusive com recursos financeiros, para multiplicar os conhecimentos na área.

\subsection{Diretrizes}

2.2.1. Promover e garantir a articulação e integração em rede nacional das intervenções para tratamento, recuperação, redução de danos, reinserção social e ocupacional (Unidade Básica de Saúde, ambulatórios, Centro de Atenção Psicossocial, Centro de Atenção Psicossocial Álcool e Drogas, comunidades terapêuticas, grupos de auto-ajuda e ajuda mútua, hospitais gerais e psiquiátricos, hospital-dia, serviços de emergências, corpo de bombeiros, clínicas especializadas, casas de apoio e convivência e moradias assistidas) com o Sistema Único de Saúde e Sistema Único de Assistência Social para o usuário e seus familiares, por meio de distribuição descentralizada e fiscalizada de recursos técnicos e financeiros.

2.2.2. Desenvolver e disponibilizar banco de dados, com informações científicas atualizadas, para subsidiar o planejamento e avaliação das práticas de tratamento, recuperação, redução de danos, reinserção social e ocupacional sob a responsabilidade de órgãos públicos, privados ou de organizações não-governamentais, devendo essas informações ser de abrangência regional (estaduais e municipais), com ampla divulgação, fácil

acesso e resguardando o sigilo das informações.

2.2.3. Definir normas mínimas que regulem o funcionamento de instituições dedicadas ao tratamento, recuperação, redução de danos, reinserção social e ocupacional, quaisquer que sejam os modelos ou formas de atuação, monitorar e fiscalizar o cumprimento dessas normas, respeitando o âmbito de atuação de cada instituição.

2.2.4. Estabelecer procedimentos de avaliação por uma comissão tripartite e paritária para as diversas modalidades de tratamento, recuperação, redução de danos, reinserção social e ocupacional, para usuários dependentes e familiares, com base em parâmetros comuns, adaptados às realidades regionais, permitindo a comparação de resultados entre as instituições, aplicando para esse fim recursos técnicos e financeiros.

2.2.5. Desenvolver, adaptar e implementar diversas modalidades de tratamento, recuperação, redução de danos, reinserção social e ocupacional dos dependentes químicos e familiares às características específicas dos diferentes grupos: crianças e adolescentes, adolescentes em medida socioeducativa, mulheres, gestantes, idosos, pessoas em situação de risco social, portadores de qualquer co-morbidade, população carcerária e egressos, trabalhadores do sexo e populações indígenas, por meio da distribuição descentralizada de recursos técnicos e financeiros. 
2.2.6. Propor, por meio de dispositivos legais, incluindo incentivos fiscais, o estabelecimento de parcerias e convênios em todos os níveis do Estado, que possibilitem a atuação de instituições e organizações públicas, não- governamentais ou privadas que contribuam no tratamento, na recuperação, redução de danos, reinserção social e ocupacional.

2.2.7. Propor a criação de taxas específicas para serem arrecadadas em todos os níveis de governo (federal, estadual e municipal) sobre as atividades da indústria de bebidas alcoólicas e do tabaco, para financiar tratamento, recuperação, redução de danos e reinserção social e ocupacional de dependentes químicos e familiares.

2.2.8. Garantir a destinação dos recursos provenientes das arrecadações do Fundo Nacional Antidrogas (composto por recursos advindos da apropriação de bens e valores apreendidos em decorrência do crime do narcotráfico) para tratamento, recuperação, reinserção social e ocupacional.

2.2.9. Estabelecer parcerias com universidades para implementação da capacitação continuada, por meio dos pólos permanentes de educação, saúde e assistência social.

2.2.10. Propor que a Agência Nacional de Saúde Suplementar regule o atendimento assistencial em saúde para os transtornos psiquiátricos e/ou por abuso de substâncias psicotrópicas, de modo a garantir tratamento tecnicamente adequado previsto na Política Nacional de Saúde.

\section{REDUÇÃO DOS DANOS SOCIAIS E À SAÚDE}

\subsection{Orientação Geral}

3.1.1 A promoção de estratégias e ações de redução de danos, voltadas para a saúde pública e direitos humanos, deve ser realizada de forma articulada inter e intra-setorial, visando à redução dos riscos, as consequiências adversas e dos danos associados ao uso de álcool e outras drogas para a pessoa, a família e a sociedade.

\subsection{Diretrizes}

3.2.1. Reconhecer a estratégia de redução de danos, amparada pelo artigo 196 da Constituição Federal, como medida de intervenção preventiva, assistencial, de promoção da saúde e dos direitos humanos.

3.2.2. Garantir o apoio à implementação, divulgação e acompanhamento das iniciativas e estratégias de redução de danos desenvolvidas por organizações governamentais e nãogovernamentais, assegurando os recursos técnicos, políticos e financeiros necessários, em consonância com as políticas públicas de saúde.

3.2.3. Diminuir o impacto dos problemas socioeconômicos, culturais e dos agravos à saúde associados ao uso de álcool e outras drogas.

3.2.4. Orientar e estabelecer, com embasamento científico, intervenções e ações de redução de danos, considerando a qualidade de vida, o bem-estar individual e comunitário, as características locais, o contexto de vulnerabilidade e o risco social.

3.2.5. Garantir, promover e destinar recursos para o treinamento, capacitação e supervisão técnica de trabalhadores e de profissionais para atuar em atividades de redução de danos. 
3.2.6. Viabilizar o reconhecimento e a regulamentação do agente redutor de danos como profissional e/ou trabalhador de saúde, garantindo sua capacitação e supervisão técnica.

3.2.7. Estimular a formação de multiplicadores em atividades relacionadas à redução de danos, visando um maior envolvimento da comunidade com essa estratégia.

3.2.8. Incluir a redução de danos na abordagem da promoção da saúde e prevenção, no ensino formal (fundamental, médio e superior).

3.2.9. Promover estratégias de divulgação, elaboração de material educativo, sensibilização e discussão com a sociedade sobre redução de danos por meio do trabalho com as diferentes mídias.

3.2.10 Apoiar e divulgar as pesquisas científicas submetidas e aprovadas por comitê de ética, realizadas na área de redução de danos para o aprimoramento e a adequação da política e de suas estratégias.

3.2.11 Promover a discussão de forma participativa e subsidiar tecnicamente a elaboração de eventuais mudanças nas legislações, nas três esferas de governo, por meio dos dados e resultados da redução de danos.

3.2.12 Assegurar às crianças e adolescentes o direito à saúde e o acesso às estratégias de redução de danos, conforme preconiza o Sistema de Garantia de Direitos do Estatuto da Criança e do Adolescente (ECA - Lei n. $\left.{ }^{\circ} 8.069 / 1990\right)$.

3.2.13 Comprometer os governos federal, estaduais e municipais com o financiamento, a formulação, implementação e avaliação de programas e de ações de redução de danos sociais e à saúde, considerando as peculiaridades locais e regionais.

3.2.14 Implementar políticas públicas de geração de trabalho e renda como elementos redutores de danos sociais.

3.2.15 Promover e implementar a integração das ações de redução de danos com outros programas de saúde pública.

3.2.16 Estabelecer estratégias de redução de danos voltadas para minimizar as consequiências do uso indevido, não somente de drogas lícitas e ilícitas, bem como de outras substâncias.

\section{REDUÇÃO DA OFERTA}

\subsection{Orientação Geral}

4.1.1 A redução substancial dos crimes relacionados ao tráfico de drogas ilícitas e ao uso abusivo de substâncias nocivas à saúde, responsáveis pelo alto índice de violência no país, deve proporcionar melhoria nas condições de segurança das pessoas.

4.1.2 Meios adequados devem ser assegurados à promoção da saúde e à preservação das condições de trabalho e da saúde física e mental dos profissionais de segurança pública, incluindo assistência jurídica.

4.1.3 As ações contínuas de repressão devem ser promovidas para reduzir a oferta das drogas ilegais e/ou de abuso, pela erradicação e apreensão permanentes destas produzidas no país, pelo bloqueio do ingresso das oriundas do exterior, destinadas ao consumo interno ou ao mercado internacional e pela identificação e desmantelamento das organizações criminosas. 
4.1.4 A coordenação, promoção e integração das ações dos setores governamentais, responsáveis pelas atividades de prevenção e repressão ao tráfico de drogas ilícitas, nos diversos níveis de governo, devem orientar a todos que possam apoiar, aprimorar e facilitar o trabalho.

4.1.5 A execução da Política Nacional sobre Drogas deve estimular e promover, de forma harmônica com as diretrizes governamentais, a participação e o engajamento de organizações não-governamentais e de todos os setores organizados da sociedade.

4.1.6 As ações do Conselho de Controle de Atividades Financeiras - COAF, do Departamento de Recuperação de Ativos e Cooperação Jurídica Internacional - DRCI/MJ, da Secretaria da Receita Federal - SRF, do Departamento de Polícia Federal - DPF, do Fundo Nacional Antidrogas - FUNAD, da Secretaria Nacional de Segurança Pública - SENASP, da Polícia Rodoviária Federal - DPRF, das Polícias Civis e Militares e demais setores governamentais, com responsabilidade na redução da oferta, devem receber irrestrito apoio na execução de suas atividades.

4.1.7 Interação permanente com o Poder Judiciário e Ministério Público, por meio dos órgãos competentes, visando agilizar a implementação da tutela cautelar, com o objetivo de evitar a deterioração dos bens apreendidos.

\subsection{Diretrizes}

4.2.1. Conscientizar e estimular a colaboração espontânea e segura de todas as pessoas e instituições com os órgãos encarregados pela prevenção e repressão ao tráfico de drogas, garantido o anonimato.

4.2.2. Centralizar, no Departamento de Polícia Federal, as informações que permitam promover o planejamento integrado e coordenado das ações repressivas dos diferentes órgãos, disponibilizando-as para as unidades da federação, bem como atender as solicitações de organismos nacionais e internacionais com os quais o país mantém acordos.

4.2.3. Estimular operações repressivas, assegurando condições técnicas e financeiras, para ações integradas entre os órgãos federais, estaduais, municipais e do Distrito Federal, responsáveis pela redução da oferta, coordenadas pelo Departamento de Polícia Federal, sem relação de subordinação, com o objetivo de prevenir e combater os crimes relacionados às drogas.

4.2.4. Incrementar a cooperação internacional, estabelecendo e reativando protocolos e ações coordenadas, fomentando a harmonização de suas legislações, especialmente com os países vizinhos.

4.2.5. Apoiar a realização de ações dos órgãos responsáveis pela investigação, fiscalização e controle nas esferas federal, estadual e municipal e o Distrito Federal, para impedir que bens e recursos provenientes do tráfico de drogas sejam legitimados no Brasil e no exterior.

4.2.6. Planejar e adotar medidas para tornar a repressão eficaz, cuidando para que as ações de fiscalização e investigação sejam harmonizadas, mediante a concentração dessas atividades dentro de jurisdição penal em que o Judiciário e a Polícia repressiva disponham de recursos técnicos, financeiros e humanos adequados para promover e sustentar a ação contínua de desmonte das organizações criminosas e de apreensão e destruição

do estoque de suas mercadorias. 
4.2.7. Manter, por intermédio da SENAD, o Conselho Nacional Antidrogas informado sobre os bens móveis, imóveis e financeiros apreendidos de narcotraficantes, a fim de agilizar sua utilização ou alienação por via da tutela cautelar ou de sentença com trânsito em julgado, bem como a conseqüente aplicação dos recursos.

4.2.8. Priorizar as ações de combate às drogas ilícitas que se destinam ao mercado interno, produzidas ou não no país, sem prejuízo das ações de repressão àquelas destinadas ao mercado externo.

4.2.9. Controlar e fiscalizar, por meio dos órgãos competentes dos ministérios da Justiça, da Saúde e da Fazenda, bem como das Secretarias de Fazenda estaduais e municipais e do Distrito Federal, todo o comércio e transporte de insumos que possam ser utilizados para produzir drogas, sintéticas ou não.

4.2.10. Estimular e assegurar a coordenação e a integração entre a Secretaria Nacional de Segurança Pública, as secretarias de segurança e justiça estaduais e do Distrito Federal, o Departamento de Polícia Federal e o Departamento de Polícia Rodoviária Federal, no sentido do aperfeiçoamento das políticas, estratégias e ações comuns de combate ao narcotráfico e aos crimes conexos.

4.2.11. Promover e incentivar as ações de desenvolvimento regional de culturas e atividades alternativas, visando à erradicação de cultivos ilegais no país.

4.2.12. Assegurar recursos orçamentários no âmbito da União, Estados e do Distrito Federal para o aparelhamento das polícias especializadas na repressão às drogas e estimular mecanismos de integração e coordenação de todos os órgãos que possam prestar apoio adequado às suas ações.

4.2.13. Intensificar a capacitação dos profissionais de Segurança Pública, dos membros do Poder Judiciário e do Ministério Público, com funções nas áreas de prevenção e repressão ao tráfico ilícito de drogas em todos os níveis de governo e no Distrito Federal, bem como estimular a criação de departamentos especializados nas atividades de combate às drogas.

4.2.14. Assegurar dotações orçamentárias para a Política de Segurança Pública, especificamente para os setores de redução da oferta de drogas, com vinculação de percentual, nos moldes das áreas de educação e saúde, com o fim de melhorar e implementar atividades, bem como criar mecanismos incentivadores ao desempenho das funções dos profissionais dessa área.

\section{ESTUDOS, PESQUISAS E AVALIAÇÕES}

\subsection{Orientação Geral}

5.1.1 Meios necessários devem ser garantidos para estimular, fomentar, realizar e assegurar, com a participação das instâncias federal, estaduais, municipais e o Distrito Federal, o desenvolvimento permanente de estudos, pesquisas e avaliações que permitam aprofundar o conhecimento sobre drogas, a extensão do consumo e sua evolução, a prevenção do uso indevido, repressão, tratamento, reabilitação, redução de danos, reinserção social e ocupacional, observando os preceitos éticos.

5.1.2 Meios necessários devem ser garantidos à realização de estudos, análises e avaliações sobre as práticas das intervenções públicas e privadas, nas áreas de prevenção, tratamento, reabilitação, redução de danos, reinserção social e ocupacional, redução da oferta, considerando 
que os resultados orientarão a continuidade ou a reformulação dessas práticas.

\subsection{Diretrizes}

5.2.1. Promover e realizar, periódica e regularmente, levantamentos abrangentes e sistemáticos sobre o consumo de drogas lícitas e ilícitas, incentivando e fomentando a realização de pesquisas dirigidas a parcelas da sociedade, considerando a enorme extensão territorial do país e as características regionais e sociais, além daquelas voltadas para populações específicas.

5.2.2. Incentivar e fomentar a realização de pesquisas básicas, epidemiológicas, qualitativas e inovações tecnológicas sobre os determinantes e condicionantes de riscos e danos, o conhecimento sobre as drogas, a extensão do consumo e sua evolução, a prevenção do uso indevido, repressão, tratamento, redução de danos, reabilitação, reinserção social e ocupacional, desenvolvidas por organizações governamentais e não-governamentais, disseminando amplamente seus resultados.

5.2.3. Assegurar, por meio de pesquisas, a identificação de princípios norteadores de programas preventivos.

5.2.4. Avaliar o papel da mídia e seu impacto no incentivo e/ou prevenção do uso indevido de álcool e outras drogas e os danos relacionados, divulgando os resultados por meio do Observatório Brasileiro de Informações sobre Drogas - OBID.

5.2.5. Garantir que sejam divulgados por meio do Observatório Brasileiro de Informações sobre Drogas - OBID e por meio impresso, pesquisas referentes ao uso indevido de álcool e outras drogas, que permitam aperfeiçoar uma rede de informações confiáveis para subsidiar o intercâmbio com instituições regionais, nacionais e estrangeiras e organizações multinacionais similares.

5.2.6. Apoiar, estimular e divulgar estudos, pesquisas e avaliações sobre violência, aspectos socioeconômicos e culturais, ações de redução da oferta e o custo social e sanitário do uso indevido de drogas lícitas e ilícitas e seus impactos na sociedade.

5.2.7. Definir e divulgar critérios de financiamento para os estudos, pesquisas e avaliações.

5.2.8. Apoiar, estimular e divulgar pesquisas que avaliem a relação custo/benefício das ações públicas vigentes, para subsidiar a gestão e o controle social da Política Nacional sobre Drogas 


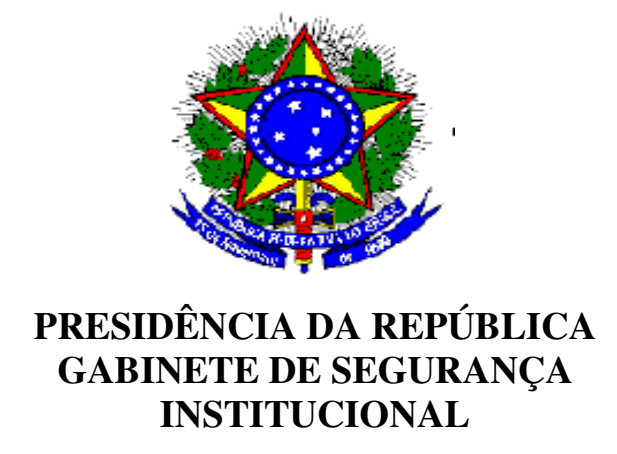

INSTITUCIONAL

\section{INTEGRAÇÃO DE COMPETÊNCIAS NO DESEMPENHO DA ATIVIDADE JUDICIÁRIA COM USUÁRIOS E DEPENDENTES DE DROGAS}




\section{Equipe técnica}

Dr. Danilo Antonio Baltieri

Dra. Camila Magalhães Silveira

Dra. Janaína Conceição Paschoal

Dr. Ricardo Abrantes do Amaral

\section{Parcerias}

Departamento de Psiquiatria da Faculdade de Medicina da USP

Departamento de Telemedicina da Faculdade de Medicina da USP

Faculdade de Direito da Universidade de São Paulo

Ministério da Justiça - Programa Nacional de Segurança Pública com Cidadania (PRONASCI)

\section{Colaboradores}

Conselho Nacional de Justiça (CNJ)

Fórum Nacional de Juizados Especiais (FONAJE)

Escola Nacional da Magistratura (ENM) 


\section{INTRODUÇÃO}

O abuso de drogas é um fenômeno complexo e multifacetado que impõe à sociedade e ao poder público uma ação conjunta a partir de políticas inter setoriais nas áreas jurídica, da educação, da saúde e da assistência social na busca de soluções para minimizar os prejuízos decorrentes deste comportamento.

$\mathrm{Na}$ área do Direito, isso tem gerado modificações nas leis específicas relacionadas ao uso de substâncias psicoativas. A regulamentação sobre drogas no Brasil teve início em 1938, pelo Decreto-Lei no 891/38 que aprovou a Lei de Fiscalização de Entorpecentes. Neste decreto, foram listadas as substâncias consideradas entorpecentes (art.1ํ); foram proibidos no território nacional o plantio, a cultura, a colheita e a exploração dessas substâncias (art.2º); foi instituída a Secção de Fiscalização do Exercício Profissional do Departamento Nacional de Saúde, única repartição autorizada a conceder certificados e autorizações de importação, exportação e reexportação de substâncias entorpecentes a drogarias, laboratórios, farmácias e estabelecimentos fabris (art.3ำ), entre outras providências.

Em 1941 foi promulgado o Decreto-Lei № 3.114, alterado em 1946 pelo Decreto-Lei no 4.647, criando a Comissão Nacional de Fiscalização de Entorpecentes e prevendo sua composição (art. $1^{\circ}$ ); sujeitando o trânsito de substâncias entorpecentes à licença concedida por esta Comissão (art.2º) e alterando alguns dispositivos do Decreto-Lei oㅜ 891/38 (arts. 3ํㅜ e 4ํ). Em 1942 foi editado o Decreto-Lei no 4.720, que fixou normas gerais para o cultivo de plantas entorpecentes, e para a extração, transformação e purificação de seus princípios ativo-terapêuticos (GRADASCHI, Mariluze. Op. cit. p. XII). Ainda em 1942, passou a vigorar o Código Penal Brasileiro (Decreto-Lei o 2.848, de 07/12/1940), que penalizava o comércio clandestino ou a facilitação do uso de entorpecentes, considerando o uso de drogas, ato delituoso contra a saúde, de perigo comum e enquadrável na classe geral dos crimes contra a incolumidade pública (VIEIRA, João. Op cit., p. XIII).

Em 1960, quando o consumo de substâncias psicoativas passou a ser considerado como um "problema social", muitas sociedades ocidentais decidiram pela proibição do consumo, posse e comercialização. Com base no senso comum, algumas das razões aventadas para a proibição foram: consumidores de 
substâncias psicoativas podem causar danos e sofrimento a outras pessoas; o uso das drogas provoca aumento nos gastos com a saúde pública; os usuários de drogas são menos produtivos e têm maior chance de morte prematura; os usuários de substâncias devem ser protegidos contra eles mesmos, à medida que eles atuam de forma auto-destrutiva; o consumo das drogas é "contagioso", ou seja, indivíduos usuários podem "convencer" outros a experimentá-las.

A posse de drogas, no Brasil, não era definida como crime antes de 1968, quando se considerava apenas o tráfico como objeto de repressão penal. A partir do Projeto de Código Penal de 1963, elaborado por Nélson Hungria, houve a referência ao porte de entorpecentes como ilícito penal. O Código Penal de 1969, que não chegou a entrar em vigor, também definia tal conduta como crime. O Decreto-Lei no 385/68 passou a incriminar o porte para uso de drogas com a mesma pena cominada ao tráfico.

Neste decreto, a justificativa para tipificar o porte era "o aumento do consumo e a freqüente impunidade dos traficantes que, quando flagrados com as substâncias proibidas, diziam-se meros usuários das drogas" (Médici, 2005).

Em 1971, foi promulgada a Lei № 5.726, tratando sobre as medidas preventivas e repressivas ao tráfico e consumo de substâncias entorpecentes. Logo em seu artigo 1ํㅡ, determinava que era dever de toda pessoa física e jurídica colaborar no combate ao tráfico de drogas. Ressaltava a importância da prevenção ao consumo de substâncias ilícitas, determinando aos Estados, Distrito Federal e Territórios que, no início de cada ano letivo, promovessem cursos aos educadores de estabelecimentos de ensino, a fim de prepará-los para o combate às drogas no âmbito escolar (art.5).

Em 21 de outubro de 1976 foi sancionada a Lei o 6.368 , que possui 47 artigos divididos em 5 capítulos: medidas de prevenção, tratamento, e recuperação, dos crimes e das penas, do procedimento criminal e das disposições gerais. Essa lei, no entanto, não diferenciava usuário de traficante. Sua abordagem era jurídicopenal e médico psiquiátrico, fazendo com que o problema fosse encarado como problema de polícia ou como problema de saúde mental (Sá, D. B. de Projeto de uma nova política de drogas no país. In: Zaluar, A (org). Drogas e Cidadania: repressão ou redução de riscos. SP:Brasiliense,1999).

Os tipos penais elaborados ao combate das drogas, ou seja, situações de traficância e de porte (respectivamente artigos 12 e 16 da antiga Lei no 6.368/76) 
configuram-se como de perigo abstrato. Classicamente, a missão do Direito Penal reside na proteção a bens jurídicos contra ataques ou perigos concretos (Silveira, 2005). Os delitos de perigo concreto são aqueles que requerem, para sua verificação, a produção de um resultado de real perigo de dano ao objeto protegido pela norma, verificável no caso fático. Tais delitos são de resultado como os delitos de lesão; porém, a sua verificação baseia-se em critérios de imputação divergentes, porque ao invés destes crimes apresentarem um resultado real lesivo de dano, eles apresentam um resultado de criação de perigo de resultado de dano, ou seja, de assunção do risco de lesão não permitido pela norma. Segundo Jakobs (1997), nos crimes de perigo concreto, existe algo mais do que a mera execução de uma ação em determinada situação subjetiva. Deve haver a verificação de que esta ação ocasiona objetivamente uma determinada situação de perigo para um objeto também determinado e visado pela ação. O mesmo autor reporta, ainda, que nos delitos de perigo concreto, o agente da ação possui juízo - conhecimento - do perigo que está produzindo, e, por conseqüência, demonstra dolo de perigo e, às vezes, dolo eventual de lesão. Já nos crimes de perigo abstrato, conforme refere Roxin (1997), pune-se a conduta perigosa por si mesma, sem que no caso concreto ocorra alguma exposição a perigo a outrem.

No campo legislativo e da política pública relacionada às causas e conseqüências do consumo abusivo de drogas, a Lei oㅜ 11.343/2006 que instituiu o Sistema Nacional de Políticas Públicas sobre Drogas (SISNAD) e prescreveu medidas para a prevenção do uso indevido, atenção e reinserção social de usuários e dependentes de drogas, é o marco jurídico de mudança de paradigma e de procedimentos penais ao atender ao pressuposto da Política Nacional sobre Drogas (PNAD) que prevê o reconhecimento das diferenças entre o usuário, a pessoa em uso indevido, o dependente e 0 traficante de drogas, tratando-os de forma diferenciada, sem, no entanto, descuidar e negligenciar os mecanismos de repressão ao tráfico.

Até a publicação da referida Lei, o usuário e dependente eram vistos, no imaginário da sociedade, como um "risco ou ameaça". Os procedimentos eram restritos a ações policiais (punição) e ao encaminhamento a hospitais psiquiátricos (doença mental). Ao contrário, no escopo da nova Lei, o indivíduo que for processado por posse de droga para uso próprio terá direito à definição de um 
projeto terapêutico individualizado (re-socialização), orientado para a inclusão social e para a redução de riscos e de danos sociais e à saúde (art. 22, inc. III).

Neste contexto, os usuários e dependentes não estarão mais sujeitos à pena privativa de liberdade, mas, sim, às medidas sócio-educativas aplicadas pelos Juizados Especiais Criminais.

Esse novo paradigma encontra-se previsto no Art. 28, caput e parágrafos, da Lei oㅜ 11.343/06, abaixo transcrito:

Art. 28. Quem adquirir, guardar, tiver em depósito, transportar ou trouxer consigo, para consumo pessoal, drogas sem autorização ou em desacordo com determinação legal ou regulamentar será submetido às seguintes penas: I Advertência sobre efeitos das drogas; II - Prestação de serviços à comunidade; III - Medida educativa de comparecimento ao programa ou curso educativo.

$\S 1^{\circ}$ Às mesmas medidas submete-se quem, para seu consumo pessoal, semeia, cultiva ou colhe plantas destinadas à preparação de pequena quantidade de substância ou produto capaz de causar dependência física ou psíquica.

$\S 2^{\circ}$ Para determinar se a droga destinava-se a consumo pessoal, o juiz atenderá à natureza e à quantidade da substância apreendida, ao local e às condições em que se desenvolveu a ação, às circunstâncias sociais e pessoais, bem como à conduta e aos antecedentes do agente.

Sendo assim, o pressuposto da ação educativa prevista nessa Lei é de que o Estado, com a participação da sociedade, não só pode como deve formular e implementar políticas ou programas de prestação de serviços à comunidade.

Como reflexo da nova Lei ำ 11.343/06 e com vistas a sua aplicação mais eficaz e adequada pelos Operadores do Direito envolvidos na persecução penal, se faz necessário o aprimoramento de conhecimentos teórico-metodológicos em áreas direcionadas à problemática das drogas (fora da ciência do direito) e adequação da ação conjunta (enfoque multidisciplinar) entre os Operadores do Direito (juízes, promotores, defensores, delegados, conciliadores, advogados e outros serventuários da justiça), os profissionais da área de atenção psicossocial (assistentes sociais, 
pedagogos, psicólogos, dentre outros) e outros profissionais da área de Segurança Pública.

Entretanto, a revisão de conhecimentos teórico-metodológicos é apenas uma das vertentes prevista neste Projeto. Este projeto, consoante às justificativas expostas na introdução, será desenvolvido por meio de quatro etapas, quais sejam:

\section{1․ Etapa: Pesquisa dirigida}

- Juízes (Juizados Especiais Criminais)

- Ministério Público

- Usuários (sentenciados)

2a Etapa: Curso de Capacitacão direcionado a 15.000 (quinze mil) Operadores do Direito dos Juizados Especiais Criminais e dos Juizados da Infância e da Juventude, profissionais da área de atenção psicossocial e outros profissionais da área de segurança pública de todo o Brasil, priorizando as cidades dos 06 Estados que integram o Projeto Ações Integradas na Prevenção ao Uso de Drogas e Violência (PRONASCI/Ministério da Justiça): Rio de Janeiro, Rio Grande do Sul, Bahia, Distrito Federal e Entorno, Espírito Santo e São Paulo.

\section{3ª Etapa: Seminários Regionais de Boas Práticas}

4a Etapa: Projeto Piloto (desenvolvimento de metodologia específica de aplicação das penas alternativas, medidas socioeducativas e das medidas protetivas). 
II. CRONOGRAMA

\begin{tabular}{|c|c|}
\hline FASES DO PROJETO & PREVISÃO \\
\hline $\begin{array}{l}\text { Etapa I } \\
\text { Pesquisa Dirigida }\end{array}$ & $\begin{array}{l}\text { 10 Momento: } \\
\text { Elaboração do instrumento: Setembro } \\
\text { Coleta de dados - Outubro/Novembro/Dezembro } \\
\text { 2o Momento: } \\
\text { Análise dos dados - Janeiro/Fevereiro } \\
\text { 30 Momento: De janeiro/2010 a abril/2011 } \\
\text { Elaboração de artigo com principais dados } \\
\text { encontrados }\end{array}$ \\
\hline $\begin{array}{l}\text { Etapa II } \\
\text { Curso de Capacitação }\end{array}$ & $\begin{array}{l}\text { 10 Momento: } \\
\text { Planejamento - Setembro } \\
\text { 20 Momento: } \\
\text { Execução do curso - Outubro a Dezembro } \\
\text { 3o Momento: } \\
\text { Elaboração de relatórios - Janeiro/Fevereiro } 2011\end{array}$ \\
\hline $\begin{array}{l}\text { Etapa III } \\
\text { Seminários Regionais }\end{array}$ & $\begin{array}{l}\text { 10 Momento: } \\
\text { Planejamento - Setembro/Outubro } \\
\text { 20 Momento: } \\
\text { Realização dos Seminários - Outubro a Dezembro } \\
\text { 3o Momento: } \\
\text { Elaboração de relatórios - Janeiro/Fevereiro } 2011\end{array}$ \\
\hline $\begin{array}{l}\text { Etapa IV } \\
\text { Projeto Piloto }\end{array}$ & $\begin{array}{l}\text { 10 Momento: } \\
\text { Planejamento - Setembro/Outubro } \\
\text { 2o Momento: } \\
\text { Diagnóstico das Instituições - Out/10 a Mar/2011 } \\
\text { 3o Momento: } \\
\text { Elaboração e validação de metodologias - Abril a } \\
\text { Junho/2011 } \\
\text { Publicação e divulgação da proposta metodológica - } \\
\text { Julho/2011 }\end{array}$ \\
\hline
\end{tabular}




\section{ESTUDO DAS POSSIBILIDADES E DIFICULDADES NA APLICAÇÃO DA LEI SOBRE DROGAS ENTRE OPERADORES DO DIREITO DOS JUIZADOS ESPECIAIS CRIMINAIS}

\section{OBJETIVOS}

- Avaliar a efetividade da Lei o 11.343/06, em termos de aplicabilidade, encaminhamento aos serviços de tratamento disponíveis, modelos educacionais existentes e resultados deste encaminhamento;

- Avaliar possíveis dificuldades na aplicação da Lei ํㅜ 11.343/06 considerando os seguintes aspectos: percepção do juiz em relação ao usuário, percepção do juiz em relação à disponibilidade técnica de sua equipe, assim como conhecimento do juiz sobre recursos comunitários disponíveis;

- Percepção do Ministério Público em relação a aplicabilidade da Lei;

- Percepção dos usuários sentenciados em relação às novas medidas da Lei.

\section{HIPÓTESES EXPERIMENTAIS}

- Aproximadamente metade dos juízes entrevistados está alocada em juizados especiais e/ou Ministério Público sem adequada equipe técnica para auxiliar no manejo dos casos a que o artigo 28 da Lei o 11.343/06 se reporta;

- Parte dos juízes entrevistados desconhece fatores relacionados com a reincidência no crime definido pelo artigo 28 da Lei no 11.343/06; 
- Parte dos juízes entrevistados desconhecem os recursos comunitários disponíveis para aplicação das medidas sócio-educativas.

\section{MÉTODO}

A primeira etapa do projeto será desenvolvida pelo Grupo Interdisciplinar de Estudos de Álcool e Drogas do Departamento de Psiquiatria da Faculdade de Medicina da Universidade de São Paulo e Faculdade de Direito da Universidade de São Paulo (FADUSP).

A pesquisa dirigida a Juízes, Ministério Público e Usuários sentenciados dos Juizados Especiais Criminais será realizada nas Comarcas das 26 Capitais e região metropolitana e no Distrito Federal e Entorno.

A partir da averiguação do número total de juízes de cada uma destas capitais, calcular-se-á um fator de homogeneidade, a fim de se determinar qual a quantidade de magistrados a serem entrevistados em cada uma destas cidades / capitais, conforme a fórmula abaixo:

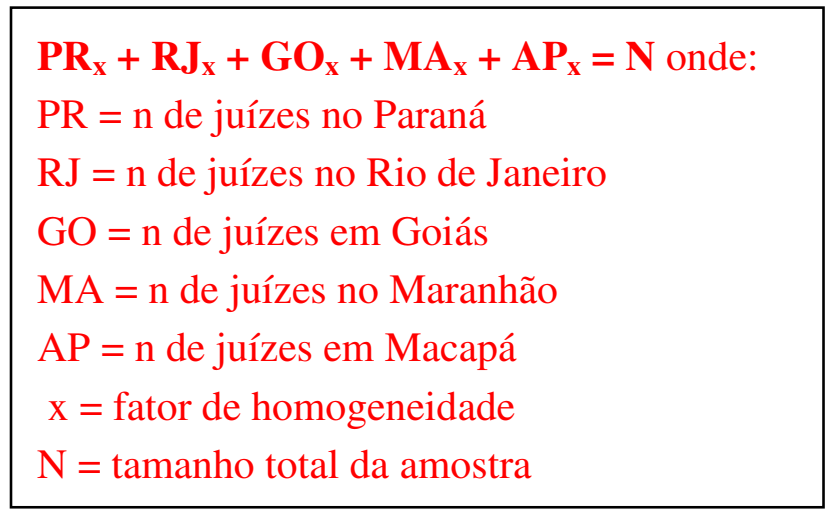

O tamanho da amostra pretendido basear-se-á na assunção de que cerca de $50 \%$ dos magistrados não aplicam adequadamente a Lei no $11.343 / 06$. O objetivo da pesquisa não é comparar os resultados das entrevistas entre magistrados de diferentes estados brasileiros, mas sim obter uma avaliação global das decisões dos magistrados quanto à Lei mencionada. Para o cálculo do tamanho da amostra, utilizamos a seguinte fórmula: 
$N=Z^{2}(\alpha / 2) \cdot p(1-p) / d^{2}$

Onde:

$p($ taxa verdadeira $)=30 \%$

$\alpha=0,05$ (Intervalo de Confiança de $95 \%$ )

$\mathrm{Z}(\boldsymbol{\alpha} / \mathbf{2})=\mathbf{1 . 9 6}$

d $($ precisão $)=0.05$

Os juízes, Ministério Público e usuários sentenciados selecionados para este estudo serão entrevistados e seu consentimento será solicitado por escrito, conforme as normas de ética em pesquisa do Hospital das Clinicas da Faculdade de Medicina da Universidade de São Paulo (ANEXO 1). Todos os magistrados serão certificados de que as informações obtidas terão caráter estritamente confidencial e científico. Também serão assegurados de que sua participação será totalmente voluntária.

\subsection{Instrumento e Procedimento}

O questionário a ser aplicado entre os magistrados (ANEXO 2) foi desenvolvido pelo Dr. Danilo Baltieri e Dra. Janaína Conceição Paschoal, autores da pesquisa, com a parceria do Dr. Roberto Bacellar, Dr. Joaquim Domingos e da Coordenadora do Projeto - representante da SENAD, Deborah Cruz. A sua confecção baseou-se no artigo 28 da Lei oㅜ 11.343/06, procurando-se investigar todos os aspectos da norma, bem como suas dificuldades inerentes no momento da aplicação.

Todas as entrevistas serão realizadas por 03 (três) assistentes sociais atuantes em juizados especiais criminais adequadamente treinadas pelos autores do projeto para este tipo de atividade, que percorrerá os 26 Estados brasileiros e Distrito Federal. Desta forma, as entrevistas serão realizadas face-a-face com os magistrados. Isso dirime possíveis problemas de confiabilidade.

Após determinar o número de juízes a serem entrevistados em cada um dos vinte e seis estados e Distrito Federal, será solicitada à FONAJE uma lista contendo o nome dos juízes de cada estado e a escolha dos entrevistados será realizada randomicamente, através de uma tabela de números aleatórios. 
O questionário será aplicado apenas 01 vez para cada juiz entrevistado. Contém 50 questões, sendo a maioria constituída por respostas do tipo 'múltipla escolha'.

\subsection{Critérios de Inclusão}

- Juízes que atuam em Juizados Especiais Criminais

- Consentimento escrito para a participação da pesquisa

- Ministério Público e Usuários

\subsection{Critérios de Exclusão}

- Outros juízes que exercem funções em outros Juizados Especiais

- Outros operadores do Direito

\subsection{Fluxograma do Estudo}

Seleção dos Entrevistados

Aplicação do questionário

Análise dos Dados Obtidos

Considerações e Conclusões

Propostas de Ação 


\subsection{Análise Estatística}

Os dados serão processados utilizando-se os programas SPSS-14 e Stata 7.0. O tamanho da amostra foi calculado utilizando o programa PASS (Power Analysis and Sample Size). As variáveis categóricas serão descritas mediante características percentuais. Em havendo variáveis contínuas, as mesmas serão descritas mediante média e desvio-padrão.

Além das características puramente descritivas do presente estudo, pretendese utilizar técnicas de regressão múltipla, objetivando determinar até que ponto determinadas variáveis explicativas prevê o resultado de uma variável dependente.

Cálculos de correlação entre diferentes variáveis também poderão ser utilizados.

O nível de significância adotado será de $5 \%$.

\subsection{Aspectos Éticos}

Antes do início da entrevista, os sujeitos do estudo serão informados sobre os procedimentos a serem realizados, bem como sobre os objetivos da pesquisa, e seu consentimento será solicitado por escrito, de acordo com as normas éticas e regulamentares vigentes do Hospital das Clínicas da Faculdade de Medicina da Universidade de São Paulo. Será informado aos entrevistados que a recusa à participação na pesquisa não Ihes causará quaisquer problemas. Aos participantes será oferecida a possibilidade de uma devolutiva do pesquisador no final da entrevista, a partir dos resultados obtidos com o questionário utilizado.

As entrevistas deverão ser realizadas em sala apropriada, respeitando-se o princípio da confidencialidade, sem a presença de terceiros.

Todos os potenciais entrevistados receberão convite escrito para a participação na presente pesquisa. 


\section{ETAPA}

\section{CURSO DE APRIMORAMENTO SOBRE DROGAS - APLICAÇÃO DAS PENAS, MEDIDAS SOCIOEDUCATIVAS E PROTETIVAS - LEIS 11.343/2006 E 8069/1990}

\section{OBJETIVO GERAL}

- Promover a capacitação dos diferentes atores envolvidos na aplicação da lei, visando ao cumprimento de penas e medidas alternativas, medidas protetivas e medidas sócioeducativas, de modo a garantir o aprimoramento do serviço judiciário e diminuição da reincidência.

\subsection{OBJETIVOS ESPECÍFICOS}

- Fornecer subsídios teórico-metodológicos que facilitem a atuação em rede da equipe multidisciplinar dos Juizados Especiais Criminais, dos profissionais da área de atenção psicossocial e da segurança pública;

- Disponibilizar aos profissionais operadores do Direito, da área de atenção psicossocial e da área de segurança pública, informações atualizadas acerca do consumo indevido de álcool e outras drogas e sua interface com a temática da criminalidade, focalizando a prevenção numa perspectiva de direitos humanos e de medidas sócio-educativas;

- Fornecer certificado de Extensão Universitária, com carga horária de 120 horas, pela USP, para todos os alunos aprovados no curso. 


\section{PÚBLICO - ALVO}

- Operadores do Direito dos Juizados Especiais Criminais e dos Juizados da Infância e da Juventude (juízes, promotores, defensores, delegados, conciliadores, advogados e outros serventuários da justiça);

- Profissionais da área de atenção psicossocial (assistentes sociais, pedagogos, psicólogos, dentre outros);

- E outros profissionais da área de Segurança Pública.

\section{EXIGÊNCIAS PARA CONTRATAÇÃO}

\section{Para a realização deste curso a Instituicão de Ensino Superior deverá:}

3.1. Oferecer plataforma virtual, equipamentos e recursos educacionais adequados para 15.000 (quinze) cursistas de todo o Brasil.

3.2. Produzir, gerar e transmitir o curso por meio de teleconferência (parabólica, streaming) para 15.000 (quinze) cursistas de todo o Brasil.

3.3. Disponibilizar estrutura física e humana para acompanhamento do cursista, via sistema 0800 (linha disponibilizada exclusivamente ao curso), via ambiente virtual de aprendizagem e via tutoria.

3.4. Possuir comprovada experiência de ensino, pesquisa e extensão na área de drogas.

3.5. Possuir credenciamento da instituição para educação à distância e de autorização ou reconhecimento para o curso a distância proposto, junto ao Conselho Nacional de Educação, conforme dispõem o artigo 80 da Lei de Diretrizes e Base e legislação complementar.

3.6. Incluir o curso, objeto deste Projeto Básico, como parte integrante dos Cursos de Extensão da Universidade, para efeito de certificação.

3.7. Emitir os certificados de extensão universitária dos participantes que concluírem - Curso com aproveitamento, num prazo máximo de 60 dias após a conclusão do Curso e emitir comprovante de entrega dos certificados a SENAD.

3.8. Indicar no mínimo 03 (três) especialistas de conteúdo com formação e comprovada experiência na área de álcool e outras drogas, para que a SENAD 
possa definir os conteudistas a partir da análise dos currículos cadastrados na Plataforma Lattes do CNPq.

3.9. Os profissionais indicados pela Instituição Executora deverão apresentar currículo comprobatório da experiência profissional, bem como toda a documentação acadêmica, quando necessária para o exercício da profissão e estarão sujeitos à aprovação por parte da SENAD.

3.10. É expressamente proibida a contratação de servidor pertencente ao quadro de pessoal da Secretaria Nacional de Políticas sobre Drogas e do Conselho Nacional de Justiça (CNJ) durante a execução dos serviços objeto do certame.

3.11. É de responsabilidade da Instituição contratada arcar com quaisquer ônus de natureza fiscal, trabalhista, previdenciária ou social, acaso decorrentes das es que lhe competirem no âmbito da execução do projeto do curso.

3.12. Permitir e facilitar, à equipe técnica da Secretaria Nacional de Políticas sobre Drogas, o acesso a toda documentação pertinente ao Projeto do Curso.

3.13. Manter registro de todos os atos e fatos e arquivo de toda documentação administrativa utilizada para a realização do curso, bem como dos documentos comprobatórios dos serviços prestados ou colocados à disposição da execução deste Projeto, que tenham sido de sua responsabilidade.

3.14. Abster-se de veicular publicidade ou qualquer outra informação acerca das atividades objeto deste Edital, sem prévia autorização da Secretaria Nacional de Políticas sobre Drogas.

3.15. Prestar esclarecimentos à Secretaria Nacional de Políticas sobre Drogas sobre eventuais atos ou fatos noticiados que a envolvam, independentemente de solicitação.

\section{DESENVOLVIMENTO}

O Projeto será desenvolvido nas seguintes etapas:

\subsection{Planejamento Geral}

A Instituição de Ensino Superior a ser contratada deverá proceder ao desenvolvimento do projeto segundo os critérios abaixo: 
- Elaborar e encaminhar à Secretaria Nacional de Políticas sobre Drogas para aprovação, um Plano de Trabalho específico contendo as etapas, metas, recursos humanos, materiais e custos para a realização do curso. Assim como, a proposta da identidade visual do curso, portal e ambiente web.

- Observar os ditames da Lei 8.666/93.

- Elaborar orçamentos e acompanhar sua execução.

- Responsabilizar-se em cumprir os prazos estipulados no cronograma.

- Mobilizar, divulgar e inscrever os cursistas para o curso.

- Selecionar e treinar a equipe de tutores para atuarem na metodologia de Ensino a Distância - EaD.

- Responsabilizar-se pelo acompanhamento pedagógico dos cursistas durante a oferta do Curso e pelo processo de aprendizagem via tutoria, avaliando os resultados desta aprendizagem para certificar os alunos aprovados.

- Encaminhar, aos dirigentes da Secretaria Nacional de Políticas sobre Drogas - SENAD, em meio magnético e sob a forma de banco de dados, o cadastro de todos os participantes do Curso, assim como o conteúdo das fichas de inscrição dos alunos e os resultados finais dos mesmos.

- Responsabilizar-se pela indicação de 01 (um) roteirista (com experiência em produção de tele-conferências) e 01 (um) especialista em desenho instrucional (com experiência em produção de materiais de educação à distância, para produção da edição digital do Curso, adequado para linguagem web).

- Capacitar os recursos humanos envolvidos na execução do desenvolvimento dos materiais didáticos do Curso nas especificidades da modalidade à distância, inclusive nas metodologias de uso das tecnologias a serem utilizadas no Curso.

- Prever a realização de reuniões de acompanhamento com os representantes do Comitê Gestor.

- Adaptar os conteúdos do material didático instrucional para o formato do curso em edição digital, compatível para publicação na WEB, no portal do Observatório Brasileiro de Informações Sobre Drogas da Secretaria Nacional de Políticas sobre Drogas, para que o público interessado na temática tenha acesso, para download, ao material disponibilizado. 
- A Instituição de Ensino Superior deverá fornecer à equipe técnica todo o material necessário ao desenvolvimento do curso, tais como: computadores, acesso à internet, material de escritório, etc.

\subsection{Planejamento e elaboração dos recursos didáticos do curso}

A Instituição de Ensino Superior a ser contratada deverá:

- Formar uma equipe técnica especializada constituída de: Conteudistas; Coordenação Geral do projeto; Coordenação administrativo-financeiro; Coordenação de produção (criação, design instrucional, design gráfico, webdesign, produção audiovisual e sistema); Apoio-Administrativo (telefonistas, recepcionistas e auxiliares); Apoio pedagógico (atualização de conteúdo na plataforma web; orientação e acompanhamento da utilização das ferramentas online disponibilizadas aos tutores e alunos); Apoio em Tecnologia da Informação (suporte técnico para equipe de produção e acompanhamento do curso bem como para toda a equipe de tutores), Equipe de tutores; Equipe de tutores coordenadores; Equipe de Informática; Secretária Executiva e Assistentes; para assumir, sob supervisão técnica da SENAD, a criação e/ou adaptação dos recursos didáticos para a execução do Projeto; Profissional para executar a avaliação externa do curso.

- Responsabilizar-se pela criação do projeto gráfico, de identidade visual do curso, portal e ambiente web.

- Responsabilizar-se pela criação e manutenção de portal específico para oferta e acompanhamento do curso.

- Adequação e tratamento da linguagem de Ensino a Distância dos conteúdos dos que irão compor o material didático instrucional.

- Elaboração e adaptação das atividades de aprendizagem do material didático instrucional do curso a distância.

- Diagramação, correção e revisão ortográfica do material didático instrucional e demais materiais pedagógicos.

- Elaboração do modelo de certificado com a identidade visual do curso para apresentação aos Gestores do Contrato e aprovação pela SENAD.

- Produção de roteiro para 06 horas de teleconferências, que devem ocorrer em três momentos distintos do curso, com duração de 2 horas cada, com 02 
(dois) conferencistas (indicados pela SENAD) por teleconferência.

- Quanto às teleconferências, caberá a Instituição de Ensino Superior:

a) fornecer passagens aéreas, hospedagem, alimentação e transporte (deslocamento residência $x$ aeroporto $x$ residência e deslocamento aeroporto $x$ hotel $x$ GREA $x$ aeroporto) aos conferencistas;

b) responsabilizar-se pela locação de estúdios; criação de cenários e adesivos de logomarcas para banners de divulgação e cenário;

c) coffee-break para os conferencistas;

d) serviços de maquilagem e figurino;

e) geração e transmissão de sinal.

- Para completar o kit didático-pedagógico, promovendo a efetiva multiplicação do conteúdo ministrado no curso, as teleconferências (além de disponibilizadas no site e no AVEA - Ambiente Virtual de Ensino e Aprendizagem) deverão ser gravadas em CD-r e distribuídas (no momento da certificação) a todos os cursistas.

- Todos os materiais deverão ser revisados e aprovados pela Equipe Técnica da SENAD e todas as modificações sugeridas deverão ser incorporadas aos referidos materiais.

- Os especialistas de conteúdo deverão assinar termo de cessão de direitos autorais do conteúdo dos textos para a SENAD e os originais dos materiais impressos, textos digitais, vídeos e conteúdos dos chats, fóruns serão de propriedade da Secretaria Nacional de Políticas sobre Drogas.

\section{CARGA-HORÁRIA}

O Curso será ofertado na modalidade de $\mathrm{EaD}$, durante um período de 03 meses, com carga horária de 120 horas, sendo 90 horas (mínimas) de estudo dos materiais didáticos disponíveis e atividades complementares e 30 horas de registro do acesso/interatividade dos profissionais aos recursos do curso (chats, fóruns, ambiente virtual, dentre outros). 


\section{RECURSOS DIDÁTICOS}

O curso contará com os seguintes recursos didáticos:

- Livro texto - contendo o conteúdo do curso e orientações para a realização das atividades de aprendizagem, exercícios de verificação de aprendizagem e indicação de textos complementares; assim como um guia de orientação ao aluno (Guia do Aluno), contendo orientações gerais sobre o funcionamento do curso e sobre o funcionamento das plataformas virtuais disponibilizadas para a realização do curso. Serão confeccionados 16.000 (dezesseis mil) livros, formato $220 \mathrm{~mm} \times 280 \mathrm{~mm}$ fechado, com aproximadamente 320 páginas a $4 \times$ 4 cores impressas em papel couchê fosco $150 \mathrm{~g} / \mathrm{m} 2$. Capa em papelão no 15 , formato $225 \mathrm{~mm} \times 290 \mathrm{~mm}$, com papel empastado couchêbrilho $150 \mathrm{~g} / \mathrm{m} 2$ e laminação bopp brilho frente a $4 \times 0$ cor; Capa interna:02 lâminas papel couche270 g/m2a 4 × 0 cor; Acabamento:Capa dura com lombada quadrada, acabamento do miolo com wire-o preto, colagem de 02 EVA na $2^{2}$ capa (cor a ser definida) com diâmetro de $15 \mathrm{~mm}$ para inserção/fixação de CD-ROM, papelão $n^{0} 15$ revestido com papel offset $150 \mathrm{~g}$ para fixação posterior do miolo com a capa. Obs.: 15.000 (quinze mil) materiais didáticos instrucionais deverão ser entregues aos alunos e 500 (quinhentos) para a SENAD e 500 (quinhentos) de margem-reserva para a instituição contratada.

- Material impresso em forma de brochura: Legislação e Políticas Públicas sobre Drogas e DVD (fornecido pela SENAD);

- Ambiente virtual de aprendizagem - dentre os recursos que os cursistas encontram no AVEA para o desenvolvimento do curso, destacam-se: os Fóruns (de avaliação e conteúdo), as Lições Virtuais, os Chats, a Biblioteca Virtual, o Material Didático-Pedagógico, as FAQs e os Tutoriais online.

- Cd-rom de conteúdo do curso;

- Ficha de controle de recebimento do material - esta ficha deverá ser devolvida à Instituição de Ensino Superior;

- Instrumento de avaliação do curso.

${ }^{* *} \mathrm{O}$ Cursista inscrito receberá, no endereço residencial, todos os materiais didáticos do curso, com 15 (quinze) dias de antecedência do início do curso**. 


\section{ACOMPANHAMENTO DO ALUNO}

O acompanhamento do aluno será realizado por meio de:

- Um centro de relacionamento ativo receptivo via telefonia gratuita na modalidade 0800, disponível no período de segunda a sexta-feira, das 08:00 às 22:00, ininterruptamente;

- Os tutores serão alunos de graduação (graduandos do curso de direito, enfermagem, psicologia ou medicina de $4^{\circ}$. ou $5^{\circ}$. anos), alunos de pósgraduação (ou especialização), em áreas de conhecimento relacionadas à área de drogas e trabalharão na relação 1/50, ou seja, cada tutor ficará responsável pelo atendimento de 50 alunos.

- A tutoria irá funcionar de segunda a sexta-feira, em três períodos distintos: das 08:00 às 12:00 horas, das 13:00 às 17:00 horas e das 18:00 às 22:00 horas.

\subsection{OS TUTORES DE CONTEÚDO DEVERÃO}

- Auxiliar os cursistas nas questões relacionadas ao conteúdo do curso e no assessoramento técnico, no período de segunda a sexta-feira, das 08:00 às 22:00.

- Acompanhar as tarefas de avaliação contínua dos cursistas por intermédio de telefonia gratuita-0800 e acesso web no Ambiente Virtual de aprendizagem.

- Organizar, divulgar e mediar os chats e fóruns.

- Programar reuniões semanais com os supervisores.

- Disponibilizar material pedagógico adequado, de acordo com o objeto do curso, e de interesse dos cursistas.

- Motivar os cursistas a participar das atividades do curso.

- Apresentar, quinzenalmente, relatório englobando as atividades desenvolvidas.

- Elaborar e apresentar o relatório final de atividades desenvolvidas pelos alunos.

\section{AVALIAÇÃO EXTERNA DO CURSO}

A Universidade Executora deverá contratar serviço especializado para realização de avaliação externa do Curso, apresentando previamente proposta de perfil dos profissionais com, no mínimo, 03 indicações para a escolha da SENAD. 0 
referido instrumento de avaliação externa será elaborado sob a orientação da equipe técnica da Secretaria Nacional de Políticas sobre Drogas.

\section{SUPERVISÃO DO PROJETO}

A supervisão geral do Projeto será feita por meio de um Comitê Gestor, que se reunirá mensalmente ou, a qualquer momento, quando necessário. Serão emitidas atas das reuniões do Comitê e levadas à apreciação Técnica da SENAD e das instituições parceiras para a homologação e tomada de decisões.

O Comitê Gestor será composto por:

- 02 (dois) profissionais da Equipe Técnica da SENAD, dos quais um será designado como coordenador do referido Comitê. O coordenador será responsável por verificar e atestar a execução das diversas etapas, conforme estabelecido no Plano de Trabalho acordado entre as partes;

- 02 (dois) profissionais indicados pelas instituições parceiras com conhecimento técnico na área relacionada ao objeto do curso;

- 02 (dois) Consultores Ad hoc - Dr. Bacellar e Joaquim Domingos (ambos juízes);

- 01 (um) representante da Universidade Executora, que será o responsável por registrar as conclusões das etapas do projeto, de encaminhar comprovantes, relatórios e outros documentos solicitados pelo Comitê Gestor.

Caberá ao Comitê Gestor fazer a análise e propor alterações e/ou ajustes se for o caso, e os submeter à SENAD.

\section{CONTEÚDO PROGRAMÁTICO}

Livro texto será elaborado conforme unidades presentes na tabela abaixo:

$\checkmark$ Drogas: classificação e efeitos no organismo

$\checkmark$ Crack

$\checkmark$ Experimentação, uso, abuso e dependência de drogas

$\checkmark$ Epidemiologia: o uso de drogas psicotrópicas no Brasil 
$\checkmark$ Mudança da Cultura Jurídica sobre Drogas

$\checkmark$ Prevenção nos Juizados Especiais Criminais

$\checkmark$ Entrevista Motivacional e Intervenção Breve com Usuários de Drogas

$\checkmark$ Modelos de Tratamento

$\checkmark$ Redução de Danos

$\checkmark$ A Família como rede de proteção do uso indevido de drogas

$\checkmark$ Redes Sociais

$\checkmark$ Implementação da justiça restaurativa por meio dos JEC e das Varas da Infância e da Juventude

$\checkmark$ Políticas de Saúde para a atenção integral a Usuários de Drogas

$\checkmark$ Uso de Drogas versus Violência e Criminalidade

$\checkmark$ Texto direcionado às Varas da Infância e da Juventude 


\section{3․ ETAPA}

\section{SEMINÁRIOS REGIONAIS DE BOAS PRÁTICAS}

\section{OBJETIVO GERAL}

- Promover 05 (cinco) Seminários Regionais visando à troca de experiências entre os Operadores do Direito e a equipe multidisciplinar dos Juizados Especiais Criminais, quanto à aplicabilidade das penas alternativas e medidas sócioeducativas.

\section{OBJETIVOS ESPECÍFICOS}

- Desenvolver o modelo de organização em rede dos diversos Juizados Especiais Criminais possibilitando uma padronização e uniformização de procedimentos com o objetivo de facilitar o trabalho a ser realizado junto ao usuário de drogas.

- Promover a troca de informações entre os diversos órgãos do Poder Judiciário e propiciar a formação de uma cultura no tratamento das questões dos usuários das drogas.

- Conhecer e valorizar as diferenças regionais.

\section{JUSTIFICATIVA}

A vulnerabilidade dos usuários de drogas, agravada pela criminalização do consumo, exige uma articulação efetiva e inventiva entre a rede de cuidados e outras políticas setoriais, como justiça, segurança pública, trabalho, educação, ação social (Delgado e col., Reforma Psiquiátrica e política de saúde mental no Brasil, In: MELLO, MELLO e KOHN, Epidemiologia da Saúde Mental no Brasil, p.76, ARTMED, 2007). Todo o modelo de tratamento das questões legais sobre o uso de drogas foi desenvolvido a partir do conceito de integração entre os diferentes atores e equipamentos públicos disponíveis. Entretanto, é fundamental conhecer a realidade 
dos serviços públicos, tanto no que diz respeito a sua acessibilidade quanto a sua eqüidade, para assegurar a articulação e a cooperação intersetorial.

\section{METODOLOGIA}

Em cada seminário, haverá oficinas temáticas coordenadas, cada uma, por dois profissionais, preferencialmente, um relacionado à área de saúde e outro à área jurídica, a fim de promover discussões sobre os temas. Ao final das discussões, esses profissionais deverão apresentar à plenária a síntese dos trabalhos do grupo sobre os seguintes temas propostos:

1. Histórico penal;

2. Conhecimento, aplicabilidade e compreensão da dimensão da lei;

3. Compreensão do modelo de rede;

4. Esboço da rede existente;

5. Diferenciação entre os diversos padrões de consumo das substâncias psicoativas;

6. Compreensão do caráter crônico do comportamento de uso de drogas e do desenvolvimento de estratégias para recuperação;

7. Acessibilidade dos serviços (jurídico, de saúde, social);

8. Extensão e limitações da ação dos Juizados Especiais Criminais;

9. Discutir os fatores que influenciam na decisão do magistrado e como os profissionais da área de saúde tratam os diferentes casos.

\section{PÚBLICO - ALVO}

- Operadores do Direito dos Juizados Especiais Criminais e Juizados da Infância e da Juventude;

- Profissionais da área de atenção psicossocial (assistentes sociais, pedagogos, psicólogos, dentre outros);

- Profissionais da área de Segurança Pública. 


\section{DATAS E LOCAIS}

\begin{tabular}{|c|}
\hline REGIÕES \\
\hline SUL (RS/SC/PR) Cidade: Curitiba/PR \\
\hline $\begin{array}{c}\text { SUDESTE (SP/MG/RJ/ES)Cidade: } \\
\text { Rio de Janeiro/RJ }\end{array}$ \\
\hline $\begin{array}{c}\text { NORTE } \\
\text { Cidade: Porto Velho/RO }\end{array}$ \\
\hline NORDESTE Cidade: Maceió/AL \\
\hline CENTRO-OESTECidade: Brasília/DF \\
\hline
\end{tabular}

\section{OPERACIONALIZAÇÃO}

- Criação da identidade visual do Seminário;

- Desenvolver ficha de inscrição dos participantes;

- Desenvolver modelo básico para as oficinas;

- Desenvolver formato de relatório a ser produzido ao final de cada oficina e cada Seminário;

- Desenvolver mecanismo de avaliação geral do evento para ser preenchido pelos participantes;

- Acionar os veículos de comunicação locais;

- Os diversos atores e equipamentos cadastrados no Ministério da Justiça e no Ministério da Saúde, de cada uma das regiões, serão contatados a partir de divulgação dos seminários via internet, seis meses antes da realização dos seminários;

- Na divulgação será informado endereço na internet para inscrição;

- No endereço, estará disponível ficha de inscrição com pedido de informações sobre nome, endereço, local de trabalho, profissão, área de atuação, tipo de vínculo com o serviço (público, ONG, OS ou privado), forma de acesso ao seminário e necessidade de diária;

- Providenciar e enviar aos Estados a arte do material de divulgação dos Seminários Regionais; 
- Organização geral do evento (transporte, logística, equipamentos, arrumação do local do evento, recepcionistas etc.);

- Aquisição de passagens aéreas para os coordenadores dos seminários, a equipe técnica do projeto e para os participantes (de acordo com as informações contidas na ficha de inscrição) (Reservas de hotéis e de passagens);

- Condução dos seminários com ênfase no estímulo à elaboração de relatório ao final de cada oficina e cada seminário. 


\section{DESENVOLVIMENTO DE METODOLOGIA ESPECÍFICA DE APLICAÇÃO dAS PENAS ALTERNATIVAS, MEDIDAS SOCIOEDUCATIVAS E DAS MEDIDAS PROTETIVAS}

\section{OBJETIVO GERAL}

- Implementar Projeto nos Estados do Paraná, Rio de Janeiro e no Distrito Federal a fim de desenvolver metodologia específica no que se refere a aplicabilidade das penas alternativas, medidas sócio-educativas e medidas protetivas;

- Identificar experiências que apresentaram resultados positivos a partir da aplicação da Lei no 11.343/06 tendo em vista a construção de uma metodologia capaz de ser replicada nos Juizados Especiais Criminais do Brasil.

\section{METODOLOGIA}

\subsection{Fase 1 - Identificação - "Boas Práticas"}

- Definir junto a SENAD indicadores para seleção e avaliação de metodologias (JEC - que apresentaram resultados positivos a partir da aplicação da Lei), apresentadas durante os Seminários Regionais;

\subsection{Fase 2 - Diagnóstico das Instituições}

- Realizar visita de campo nos Estados onde será implementado o Projeto Piloto: Paraná, Rio de Janeiro e Distrito Federal, tendo em vista conhecer a dinâmica, o funcionamento e a estrutura institucional (diagnóstico);

- Criação de um instrumento de avaliação a ser elaborado pelos pesquisadores deste projeto juntamente com os juízes responsáveis pelos JEC dos 3 Estados estudados. Este instrumento contará com 2 sessões: 


\section{Sessão 1:}

- Caracterização e identificação do perfil do JEC quanto a sua dinâmica, funcionamento e estrutura institucional. Verificação do percentual de usuários, réus primários ou reincidentes. Medidas aplicadas e porcentagem de cumprimento das mesmas.

\section{Sessão 2:}

- Identificação do perfil do usuário em cumprimento de medidas alternativas por uso de drogas (faixa etária, nível educacional, estado civil, vínculo empregatício, droga mais utilizada, padrão de uso, idade de início do uso e idade de início dos problemas, índice de descumprimento das alternativas penais acordadas na transação penal e justificativas associadas (por ex. prestação serviços comunitários junto a instituições filantrópicas)).

\section{Aplicação do questionário}

- O instrumento será aplicado em dois momentos, ou seja, em um momento zero antes da intervenção e no final do estudo. Chamamos de intervenção medidas de capacitação e treinamento da equipe multidisciplinar dos Juizados Especiais Criminais dos Estados do Paraná, Rio de Janeiro e no Distrito Federal, criadas a partir das metodologias discutidas nos seminários regionais.

- Serão produzidos materiais pedagógicos para utilização em atividades com os usuários e oferecidas duas palestras para a equipe multidisciplinar que trabalha na linha de frente com estes usuários.

\subsection{Fase 3 - Elaboração e Validação das Metodologias}

- A partir dos resultados obtidos na pesquisa inicial serão avaliadas as técnicas e instrumentos utilizados nos JEC e serão propostas reuniões técnicas para adequação da metodologia adotada nos JEC;

- Após a replicação dos questionários, serão definidos os indicadores para validar a metodologia aplicada nos Estados e Distrito Federal (após 01 ano) - tendo em 
vista a construção de uma metodologia capaz de ser replicada para outros contextos (servir de modelo a outros Juizados Especiais Criminais (Brasil).

\subsection{Fase 4 - Publicação e Divulgação da Proposta Metodológica}

- Tabulação dos dados encontrados a partir da aplicação dos questionários aplicados no início e fim da pesquisa;

- Verificação dos indicadores de sucesso e ou fracasso relacionados à intervenção;

- Publicação e divulgação da proposta metodológica (envio do material áudio-visual aos Juizados Especiais Criminais - participaram da Pesquisa Dirigida e Curso de Capacitação). 
Ministério da Saúde

Secretariaria de Atenção a Saúde

Departamento de Ações Programáticas Estratégicas

Coordenação Nacional de Saúde Mental, Álcool e outras Drogas

\title{
CONSULTÓRIO DE RUA DO SUS
}

Editoria responsável: Ministério da Saúde

Coordenação Nacional de Saúde Mental, Álcool e outras Drogas

Organizadores:

\author{
Mírian Gracie Plena \\ Miriam Di Giovanni \\ Márcia Landini Totugui \\ Valéria Cristina da Silva \\ Pedro Gabriel Godinho Delgado
}

Assessoria técnica do Projeto Consultórios de Rua do SUS

Aliança de Redução de Danos Fátima Cavalcanti - Faculdade de Medicina Universidade Federal da Bahia

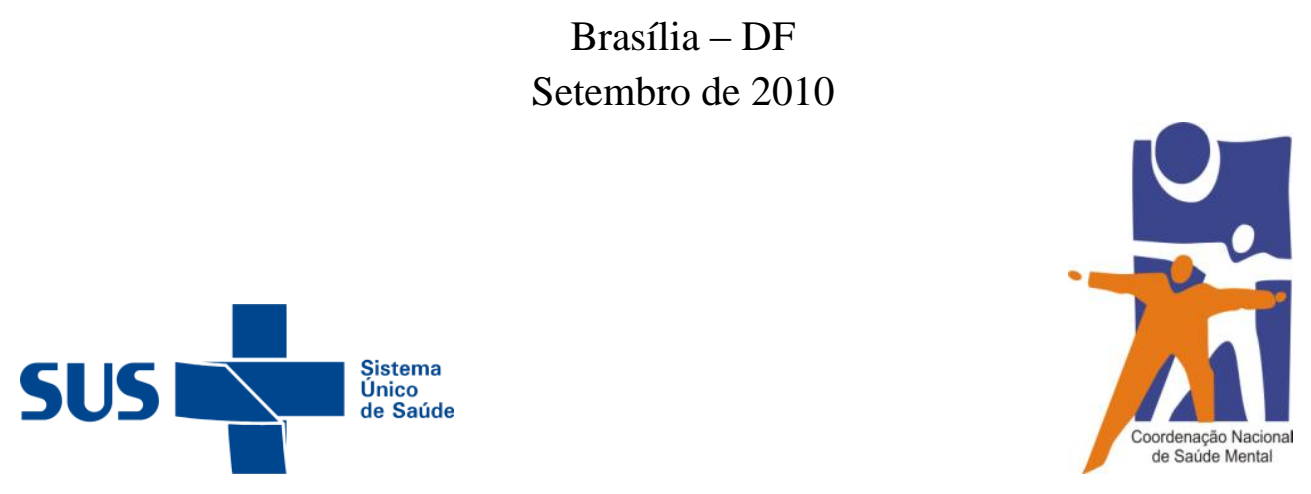




\section{FICHA CATALOGRÁFICA}

Ministério da Saúde. SAS/DAPES. Coordenação Nacional de Saúde Mental.

Consultórios de Rua do SUS. Material de trabalho para a II Oficina Nacional de Consultórios de Rua do SUS. Texto final de Mirian Gracie Plena, Miriam Giovanni, Márcia Totughi, Valéria Cristina da Silva e Pedro Gabriel Godinho Delgado.

Ministério da Saúde/Convênio Escola Politécnica Joaquim Venâncio - FIOCRUZ: Brasília, setembro de 2010, 48 p.

Como referir este texto:

MINISTÉRIO DA SAÚDE. Coordenação Nacional de Saúde Mental. Consultórios de Rua do SUS. Material de trabalho para a II Oficina Nacional de Consultórios de Rua do SUS. Ministério da Saúde/EPJN-FIOCRUZ : Brasília, setembro 2010, 48 p. 


\section{Sumário}

Apresentação

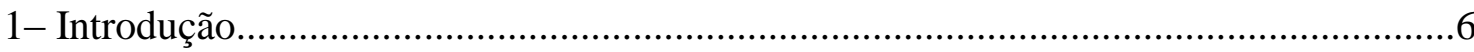

2 - Panorama Nacional das Políticas sobre Álcool e outras Drogas no Brasil..................7

3- Breve História dos Consultórios de Rua...................................................................

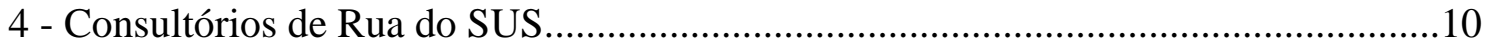

4.1 Em que consistem os Consultórios de Rua?.............................................................

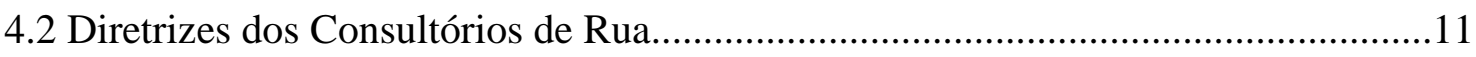

4.3 Quais os princípios que norteiam essa prática?......................................................12

4.4 Quais os objetivos dos Consultórios de Rua?..........................................................13

4.5 Etapas preliminares e operacionalização dos Consultórios de Rua...........................14

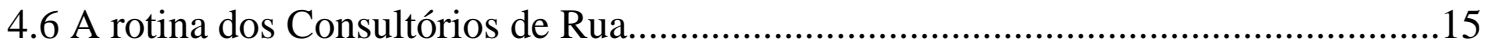

4.7 Como os Consultórios de Rua se articulam com a rede setorial e com a

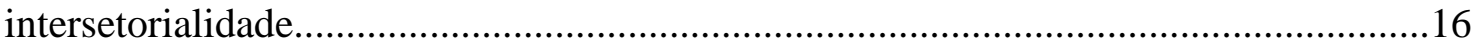

4.8 Que municípios devem implantar os Consultórios de Rua.........................................17

5- Experiências exitosas de Consultórios de Rua. (relato de um caso) ........................18

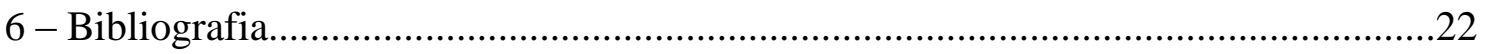

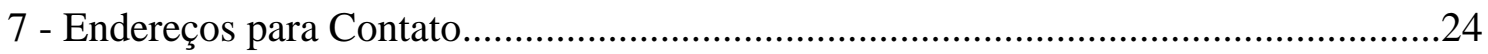

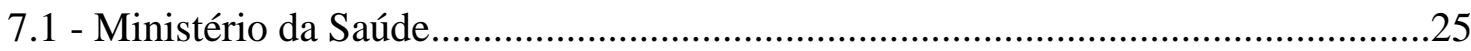

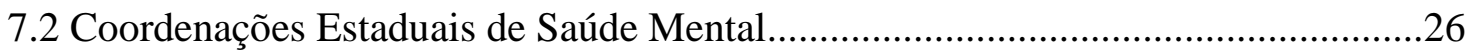

7.3 Consultórios de Rua apoiados pelo Ministério da Saúde ..................................27

Anexos.

Anexo 1 - I Oficina Nacional de Projetos de Consultório de Rua - Relatório Final. .29 Anexo 2 - II Chamada de Projetos de Consultório de Rua - Ministério da Saúde, abril de 2009

Anexo 3 - Plano Emergencial de Ampliação do Acesso ao Tratamento e Prevenção em

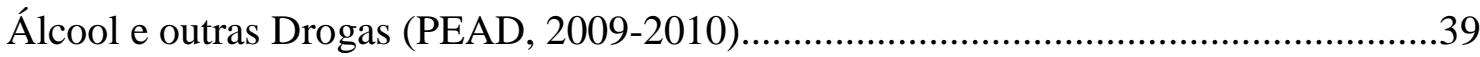

Anexo 4 - Plano Integrado de Enfrentamento do Crack - (PIEC, 2010).........................54

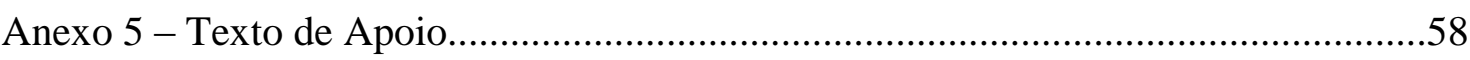

“Álcool e outras drogas como desafio para a saúde e as políticas intersetoriais contribuições para a IV Conferência Nacional de Saúde Mental - Intersetorial” 


\section{APRESENTAÇÃO}

O cenário epidemiológico atual do consumo prejudicial de substâncias psicoativas, especialmente álcool, cocaína (na forma de cloridrato ou pó, crack, merla e pasta base) e inalantes, e as graves conseqüências sanitárias e sociais para os usuários e a comunidade, têm convocado diferentes setores do governo e da sociedade civil para a criação de estratégias e intervenções com vistas à prevenção, promoção da saúde, tratamento e redução de danos sociais e à saúde.

A infreqüente procura por ajuda e o baixo acesso aos serviços da rede de saúde por parte da população usuária de álcool e outras drogas em situação de rua, em especial as crianças, adolescentes e jovens, e ainda o predomínio de ofertas de cuidado baseadas na abstinência como objetivo exclusivo e de abordagens terapêuticas desenvolvidas quase exclusivamente no interior de instituições de saúde têm excluído grande parte dos usuários das ações de assistência e prevenção.

Trata-se de uma distância histórica entre os serviços da rede de saúde e a população usuária de drogas em situação de rua, que levanta, há muito tempo, a necessidade de articular intervenções biopsicossociais efetivas, urgentes e integradas in loco. É preciso potencializar as ações em contexto de rua e sua articulação com as redes de atenção integral voltadas para a população usuária, especialmente crianças, adolescentes e jovens em estado de vulnerabilidade e risco de naturezas diversas.

O Ministério da Saúde tem buscado intervir nas causas e efeitos do consumo prejudicial de álcool e outras drogas, em conjunto com outras políticas sociais, por meio das ações previstas no Plano Emergencial de Ampliação do Acesso ao Tratamento e Prevenção em Álcool e outras Drogas no Sistema Único de Saúde SUS (PEAD 2009-2010), instituído pela Portaria no 1190, de 04 de junho de 2009, e do Plano Integrado de Enfrentamento ao Crack e outras Drogas (PIEC), instituído pelo Decreto Presidencial n $^{\circ} 7179$ de 20 de maio de 2010.

Parte integrante desses Planos, o Consultório de Rua (CR) constitui importante dispositivo público componente da rede de atenção substitutiva em saúde mental, buscando reduzir a lacuna assistencial histórica das políticas de saúde voltadas para o consumo prejudicial de álcool e outras drogas por pessoas em situação de rua, por meio da oferta de ações de promoção, prevenção e cuidados primários no espaço da rua. Visa substituir um modelo assistencial pautado na hegemonia do modelo biomédico, saindo da lógica da demanda espontânea e da abordagem única de abstinência. Propõe uma abordagem de oferta programada a usuários que apresentem alguma demanda, ainda que não formulada através de uma procura espontânea às instituições de cuidado. A abordagem preventiva e de cuidado em saúde do Consultório de Rua permite a redução dos danos potenciais do uso de substâncias psicoativas.

$\mathrm{O}$ Consultório de Rua tem como princípios norteadores o respeito às diferenças, a promoção de direitos humanos e da inclusão social, o enfrentamento do estigma, as ações de redução de danos e a intersetorialidade. Deve ainda estar alinhado às diretrizes da Política para Atenção Integral a Pessoas que Usam Álcool e Outras Drogas, do Plano Emergencial de Ampliação do Acesso ao Tratamento e Prevenção em 
Álcool e outras Drogas, do Plano Integrado de Enfrentamento ao Crack, da Política Nacional de DST/AIDS, da Política de Humanização e da Política de Atenção Básica do Ministério da Saúde.

Sua característica mais importante é oferecer cuidados no próprio espaço da rua, preservando o respeito ao contexto sócio-cultural da população. Projetos já implantados demonstram resultados satisfatórios, com relevante produção de assistência primária, de prevenção, de melhora do acesso aos serviços de saúde e de promoção de qualidade de vida. São experiências exitosas, a nível nacional, sob supervisão e avaliação científica, cujo repertório permite sua intensificação, ampliação e diversificação das ações orientadas para prevenção, promoção da saúde e redução dos riscos e danos sociais e à saúde. A diversificação de ofertas não baseadas exclusivamente na abstinência dessa população desassistida e vulnerável permite ainda que se crie um movimento de aproximação entre ela e os serviços de saúde.

A radicalidade do contexto acima exposto levou o Ministério da Saúde a um olhar mais crítico, no sentido de ampliar as ações de enfrentamento ao grave cenário do uso de álcool e outras drogas por parte de uma população historicamente excluída, que tem a "rua" como seu lugar de existência em várias fases de sua vida. Foi incentivada a implantação de 35 Consultórios de Rua, em 31 cidades brasileiras, abrangendo todas as regiões, conforme mapeamento na figura abaixo:

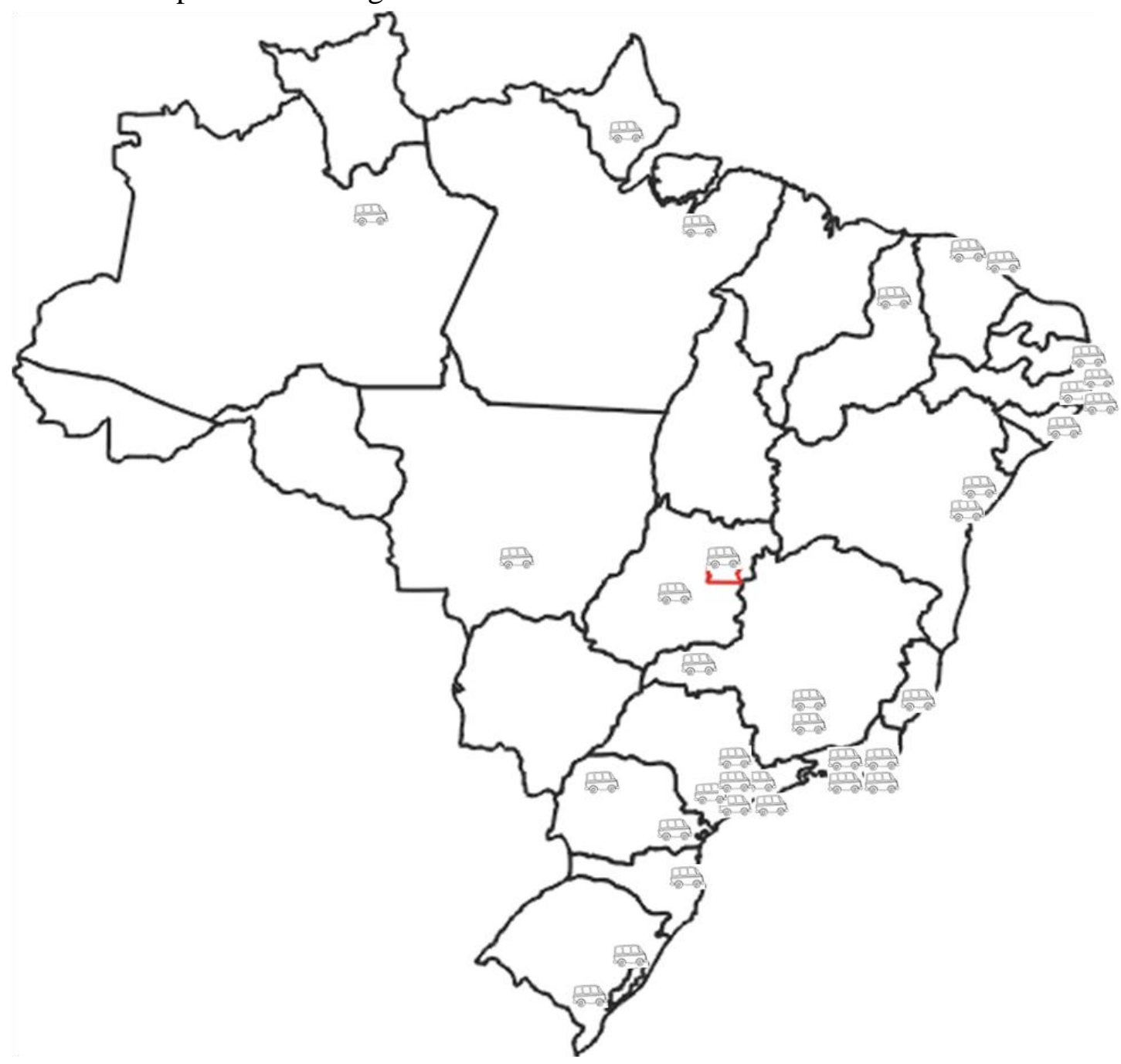




\section{1 - Introdução}

O desenvolvimento tecnológico e as novas relações econômicas forjadas pelo capitalismo globalizado provocaram uma nova forma de a sociedade organizar-se e de orientar-se, trazendo profundas alterações nas relações sociais, com a quebra de laços que teciam as redes comunitárias (BAUMAN, 1999; LIPOVETZKY, 2004). Uma das conseqüências mais nefastas do novo capitalismo é a exclusão, provocada pelo desemprego em massa. Uma considerável parcela da população, a cada dia se vê, inesperadamente, sem condições de colocação no mercado de trabalho, e sem nenhuma possibilidade de assegurar as condições mínimas de uma vida digna. Este fenômeno é observável no cotidiano das cidades em diferentes países do mundo, incluindo o Brasil.

O rebaixamento social imposto pelas novas formas de produção econômica modificou o perfil das populações de rua. Aos grupos de moradores de rua de décadas atrás, compostos de pedintes, hippies e egressos de hospitais psiquiátricos, somam-se hoje novos integrantes: desempregados e subempregados, adultos desocupados (BURSZTYN, 2000), resultados do desemprego em massa, que passaram a 'engordar'" as filas da "marginalidade avançada" nos grande centros urbanos (WACQUANT, 2001).

No conjunto dos moradores de rua insere-se um sem números de usuários de substâncias psicoativas, que ocupam o espaço público como uma forma de habitar o universo mais próximo da rede de sociabilidade em torno do consumo de drogas. Muitos não foram para a rua com o propósito de usar, mas, estando no contexto da rua, passam a utilizar drogas como meio de inserção no grupo de rua. A seguir a relação com o consumo de substâncias psicoativas prescinde da cadeia de relações sociais estabelecidas, e viver na rua passa a ser condição para a continuidade do consumo, visto a desagregação familiar e social que já ocorreu, como resultante do fato em si.

Dentre esses subgrupos, as crianças e adolescentes constituem uma parcela importante dos excluídos sociais. Convivendo em lares impregnados de violências concretas e subjetivas, inúmeras crianças saem às ruas em busca do alívio das tensões familiares ou de ajuda financeira. A situação dos filhos das camadas subalternizadas da sociedade tem sido dramaticamente vivida, na medida em que "ao tentar fugir do inferno de suas casas acabam no inferno da não-existência", na expressão de Castells (1999), indo à busca de uma liberdade, mas caindo no encontro com as drogas, violências de todas as formas, marginalidade, prostituição, tráfico.

No Brasil, o percurso das crianças e adolescentes em situação de rua tem sido largamente documentado em diversas pesquisas (NERY, 1993; NOTO, 1993; 1997, 2003; BUCHER, 1996; CARVALHO, 1999; DIOS, 1999; CEBRID, 1983, 1987, 1989, 2004). Estes estudos mostram a perene condição de vida desses jovens, constante nos últimos 20 anos, assim como a comprovação do aumento de consumo de todas as substâncias psicoativas utilizadas por esses grupos. Os estudos evidenciam estréia na relação do consumo de drogas pela população de rua com uma estratégia de sobrevivência nestes contextos. Seus efeitos fornecem uma multiplicidade de sensações, não só prazerosas, como euforia e poder, mas alterações da percepção da realidade que promovem uma proteção psíquica contra a dolorosa realidade externa e interna. 


\section{2 - Panorama Nacional das Políticas Sobre Álcool e outras Drogas}

A dimensão do consumo de substâncias psicoativas tem levado as diversas políticas, na última década, à renúncia de ações reducionistas, unilaterais e proibicionistas. Fatores como o aumento da oferta e da procura por substâncias psicoativas, as novas formas de consumo e de tipos de drogas, o grave contexto de riscos sociais e vulnerabilidades de diversas naturezas, dentre outros, tornaram claro a necessária passagem de uma postura restritiva de guerra às drogas para a composição e compartilhamento entre as diversas áreas, para busca de uma pluralidade de pressupostos, de interfaces e de ações integrais exigidas pela complexidade do fenômeno (TOTUGUI et al., 2010).

No próprio campo das políticas públicas de saúde, há relevantes transformações que priorizam o protagonismo do usuário, a perspectiva dos imperativos sociais do consumo, dos direitos humanos e da cidadania. São transformações que contribuem para problematizar o modo como as instâncias intersetoriais percebem o usuário de álcool e outras drogas, as diferentes relações e lugares que a droga ocupa em sua vida e na sociedade.

Nesse sentido, é preciso reconhecer os avanços promovidos pela Reforma Psiquiátrica para as políticas de saúde, em especial as voltadas para a atenção integral a usuários de álcool e outras drogas, que traz um cenário de cuidados de base comunitária e territorial, onde o contexto etnográfico e cultural da população nativa passa a ser compreendido, cada vez mais, como palco principal das ações públicas.

A visibilidade conquistada pelos modelos de cuidado de base comunitária, que se originam e se movimentam fora do espectro hospitalocêntrico, ou da abstinência como única alternativa de encontrar qualidade de vida, enfim, coloca em debate questões fundamentais, como: liberdade de escolha, responsabilidade individual, familiar e social, direito do usuário à universalidade e integralidade de ações e dever do Estado de criar condições para o exercício do autocuidado, redes sociais de apoio e sua conexão com as redes informais dos usuários, bem como outros (MINISTÉRIO DA SAÚDE, 2003)..

É a partir desse contexto que as estratégias individuais e coletivas de redução de danos e de riscos sociais e à saúde passam a fazer parte do repertório das políticas públicas, em especial da saúde, voltadas para o acolhimento da população usuária de álcool e outras drogas.

Em 2003, a Política do Ministério da Saúde de Atenção Integral ao Usuário de Álcool e outras Drogas elege a redução de danos como estratégia de saúde pública, na qual é incentivada a criação e sistematização de intervenções junto à população usuária que, devido ao contexto de vulnerabilidade, não querem ou não desejam parar o uso da droga. Pela primeira vez, em âmbito governamental, as ações de redução de danos são assumidas como relevantes intervenções de saúde pública, para ampliar o acesso e as ações dirigidas a uma população historicamente desassistida de contato com o sistema de saúde. Diversos mecanismos de fortalecimento dos serviços da rede de saúde têm 
sido implantados, com vistas à potencialização das experiências comunitárias no SUS, sob a lógica da redução de danos.

O baixo índice da procura e de acesso aos serviços da rede pública, principalmente pela população usuária de álcool e outras drogas em situação de extrema vulnerabilidade e riscos, justifica a implementação de intervenções biopsicossociais mais efetivas e integradas in loco.

Por isso mesmo, o Ministério da Saúde instituiu o Plano Emergencial de Ampliação do Acesso ao Tratamento e Prevenção em Álcool e Outras Drogas (PEAD 2009-2010, Portaria/MS no 1.190, 04 de junho de 2009), cujas diretrizes são: o direito ao acesso ao tratamento, a redução da lacuna assistencial, o enfrentamento do estigma, da qualificação das redes de saúde, da adoção da estratégia de redução de danos e do reconhecimento de determinantes sociais de vulnerabilidade, risco e padrões de consumo.

O PEAD tem como principal objetivo contribuir para a ampliação do acesso aos cuidados de saúde da rede SUS para usuários de álcool e outras drogas, implementar intervenções em contexto de rua com a articulação de diferentes redes de atenção em álcool e outras drogas. Sua principal população-alvo são crianças, adolescentes e jovens moradores de rua em situação de vulnerabilidade e risco

O Ministério da Saúde, em conjunto com outras políticas sociais, por meio das ações previstas no Plano Integrado de Enfrentamento do Crack e outras Drogas (PIEC/2010, Decreto $\mathrm{n}^{\mathrm{o}}$ 7.179, 20 de maio de 2010), busca intervir nas causas e efeitos do consumo de álcool e outras drogas, oferecendo cuidados de atenção com base na perspectiva da redução de danos sociais e à saúde. Investimentos e estímulos às estratégias de redução de danos nos cuidados integrais voltados para o uso abusivo de álcool e outras drogas foram oferecidos, como os Projetos de Consultórios de Rua do SUS.

\section{3 - Breve Histórico dos Consultórios de Rua}

O Consultório de Rua é uma experiência que surgiu no início de 1999, em Salvador, na Bahia, realizada pelo Centro de Estudos e Terapia do Abuso de Drogas CETAD, instituição criada como extensão da Faculdade de Medicina da Universidade Federal da Bahia (UFBA). O projeto foi idealizado pelo Prof. Antônio Nery Filho no início dos anos noventa, como uma resposta ao problema das crianças em situação de rua e uso de drogas.

Foi somente no início de janeiro de 1999, entretanto, que o projeto foi concretizado pela primeira vez, a partir de uma parceria com a Prefeitura Municipal de Salvador. Durante os oito anos seguintes a experiência foi possível com apoio financeiro de outras instâncias governamentais, como o Ministério da Saúde, Secretaria Nacional Sobre Drogas - SENAD, Secretaria de Combate à Pobreza e Secretaria do Trabalho e Ação Social do Governo do Estado da Bahia (OLIVEIRA, 2009).

Em maio de 2004 o Consultório de Rua foi implantado no primeiro CAPS AD de Salvador, seguindo até dezembro de 2006. Tanto o CETAD, de natureza ambulatorial, quanto o CAPS AD, caracterizado como um espaço de permanência diária 
permitem uma avaliação do funcionamento do Consultório de Rua na arquitetura da rede institucional de serviços para usuários de álcool e outras drogas. O trabalho articulado com o CAPS AD demonstrou que a retaguarda do Consultório de Rua favorece o fluxo de encaminhamento e a inserção na rede dos usuários mais comprometidos com o uso e em situação de maior vulnerabilidade social.

Como experiência inaugural, o primeiro Consultório de Rua de Salvador foi desenvolvido a partir das premissas desenhadas no seu projeto original. À medida que a prática foi acontecendo, ele foi sendo ajustado, sem perder suas características essenciais. As especificidades da população e os contextos do trabalho, com características tão especiais, foram determinando mudanças que levaram à forma mais adequada de a equipe operacionalizar seu funcionamento e, deste modo, também ao melhor atendimento às demandas e necessidades dos usuários. Assim, a composição multidisciplinar da equipe foi assumindo nova configuração, até se encontrar o conjunto de categorias profissionais que possibilitasse mais resolutividade das demandas e maior conforto para a equipe no seu modo de atuar.

A avaliação da experiência ocorrida entre 1999 até 2006 permitiu elaborar uma consideração sobre a pertinência deste dispositivo como alternativa para a abordagem e atendimento aos usuários de drogas em situação de grave vulnerabilidade social, e com maior dificuldade de aderir ao modelo tradicional dos serviços da rede (OLIVEIRA, 2009). Deste modo, em 2009 o Ministério da Saúde propõe o Consultório de Rua como uma das estratégias do Plano Emergencial de Ampliação de Acesso ao Tratamento e Prevenção em Álcool e outras Drogas no Sistema Único de Saúde- PEAD, sendo incluída também, em 2010, no Plano Integrado de Enfrentamento ao Crack, com o objetivo de ampliar o acesso aos serviços de saúde, melhorar e qualificar o atendimento oferecido pelo SUS às pessoas que usam álcool e outras drogas através de ações de rua.

A experiência do Consultório de Rua de Salvador serve, nesse momento, de referência para os novos projetos, consolidando, cada vez mais, o seu lugar na rede de atenção para os usuários de álcool e outras drogas que vivem nas áreas de maior risco social nos espaços urbanos.

O panorama de jovens em situação de rua e uso de drogas vivendo sob grave condição de vulnerabilidade social, em exposição a riscos à saúde física e psíquica, que se repete em diversas cidades, vem sendo observado gradativamente desde as três últimas décadas em Salvador. Era notável a ausência de demanda para atendimento especializado de uma grande parcela destes usuários, que dificilmente procurava o CETAD/UFBA, um centro de referência para tratamento dos problemas decorrentes do consumo de psicoativos na cidade.

No final da década de noventa, a cidade passou por um grande estímulo para o turismo, e a reforma do Pelourinho no Centro Histórico de Salvador marcou este momento. Esse espaço no centro da cidade, ao ganhar vida nova com a restauração dos casarios centenários, atraiu a visitação pública de inúmeros turistas. Crianças e adolescentes em situação de rua também foram atraídas para o local, em busca de contatos e possibilidades de ganhar dinheiro com a mendicância em torno dos transeuntes que visitavam o lugar (OLIVEIRA, 2009). 
A grande movimentação dia e noite mantinha os meninos no local e em outros pontos de fluxo turístico da capital. O consumo de drogas já era uma constante no modo de vida destes jovens. Contudo, a chegada do crack nesta época aumentou a preocupação de técnicos da assistência social da Prefeitura, frente a um aumento da gravidade dos riscos e vulnerabilidade observados no dia a dia dos meninos e meninas, para manter o uso compulsivo da droga. A Secretaria de Trabalho e Desenvolvimento Social do município buscou uma forma mais adequada de solucionar o problema das crianças, sem a alternativa de retirada compulsória dessa população. A partir deste contexto histórico foi feita uma parceria com o CETAD/UFBA, com a disponibilização de recursos que puseram em prática o Consultório de Rua, na tentativa de uma aproximação e abordagem mais flexível e adequada a este público específico.

\section{4 - Consultórios de Rua do SUS}

\subsection{Em que consistem os Consultórios de Rua?}

Os Consultórios de Rua constituem uma modalidade de atendimento extramuros dirigida aos usuários de drogas que vivem em condições de maior vulnerabilidade social e distanciados da rede de serviços de saúde e intersetorial. São dispositivos clínico-comunitários que ofertam cuidados em saúde aos usuários em seus próprios contextos de vida, adaptados para as especificidades de uma população complexa. Promovem a acessibilidade a serviços da rede institucionalizada, a assistência integral e a promoção de laços sociais para os usuários em situação de exclusão social, possibilitando um espaço concreto do exercício de direitos e cidadania.

Sua estrutura de funcionamento conta com uma equipe volante mínima com formação multidisciplinar constituída por profissionais da saúde mental, da atenção básica, de pelo menos um profissional da assistência social, sendo estes: médico, assistente social, psicólogo, outros profissionais de nível superior, redutores de danos, técnicos de enfermagem e educadores sociais. Além desses, eventualmente, poderá contar com oficineiros que possam, estrategicamente, desenvolver atividades de arteexpressão.

Para o desenvolvimento de suas atividades necessita de carro tipo perua ("van"), usado para fazer o deslocamento da equipe profissional e dos materiais necessários à realização das ações. $\mathrm{O}$ carro, além de transportar a equipe e os insumos, tem a função de se constituir como referência para os usuários. Para isso, a caracterização do veículo deve conter sua identificação institucional, com o nome Consultório de Rua - SUS marcando a presença do serviço público de saúde. É interessante também que seu 'layout' esteja de acordo com a linguagem do público que deverá acessar - usuários jovens de substâncias psicoativas em situação de maior vulnerabilidade. Há veículos de Consultórios de Rua que foram grafitados ou que portam adesivos de símbolos contendo alguma significação para este segmento jovem. A idéia é favorecer à clientela traços de identificação com o dispositivo e promover a construção de um vínculo desde o primeiro momento. O carro é um dos elementos que 
podem contribuir para a aproximação inicial e a construção do Consultório de Rua como um referencial para os cuidados com a saúde.

O terceiro aspecto diz respeito a um ponto fixo onde os Consultórios de Rua devem se instalar em cada área de atuação previamente definida. Considerando o fato de que, em muitos locais escolhidos para a intervenção, a população alvo é flutuante, é necessário que se estabeleça um local, dia e hora para os encontros, mantendo-se a regularidade da presença da equipe de forma constante, de modo a criar uma referência e tornar os contatos mais acessíveis para os usuários.

Um aspecto de grande relevância do Consultório de Rua é exatamente ser uma proposta de clínica na rua, especializada para o atendimento de problemas relacionados ao consumo de substâncias psicoativas. A perspectiva de uma oferta programada, tal como se modela este dispositivo, implica em ofertar onde ainda não há uma demanda de ajuda explicitada. Não havendo as condições prévias estabelecidas, tudo está por se fazer. De modo que o "'lugar' do profissional é construído a partir do momento em que se coloca no contexto do trabalho, assim como o "lugar" do Consultório de Rua.

Diferentemente do trabalho dentro de uma instituição, quando é o usuário que busca o serviço e cujas condições de atendimento já estão dadas, com toda a ambiência ajudando a compor o setting terapêutico, incluindo o lugar que o profissional ocupa na organização do serviço, na rua esses 'lugares' precisam ser construídos a partir do trabalho e da posição em que os profissionais se colocam para os usuários. No seu posicionamento, a equipe deve explicitar o propósito da presença do Consultório de Rua e quais as características do seu trabalho, diferenciando-o de outras ações desenvolvidas na rua, como ações de cunho caritativo. Assim, gradativamente, vai-se demarcando o lugar do Consultório de Rua enquanto um dispositivo do campo da saúde.

\subsection{Diretrizes dos Consultórios de Rua}

- Constituir-se como dispositivos públicos componentes da rede de atenção integral em álcool e outras drogas, que ofereçam ações de promoção, prevenção e cuidados primários no espaço da rua a usuários com problemas decorrentes do uso de substâncias psicoativas.

- Priorizar o direito ao tratamento de qualidade a todo usuário de álcool e outras drogas, ofertado pela rede de serviços públicos de saúde, assegurando o acesso a ações e serviços compatíveis com as demandas dos usuários.

- Promover ações que enfrentem as diversas formas de vulnerabilidade e risco, especialmente em crianças, adolescentes e jovens.

- Ter como eixo político o respeito às diferenças, a promoção de direitos humanos e da inclusão social, o enfrentamento do estigma.

- Atuar a partir do reconhecimento dos determinantes sociais de vulnerabilidade, risco e dos padrões de consumo, levando em consideração a estreita relação entre a dinâmica social e os processos de adoecimento.

- Assegurar o cuidado no território, na perspectiva da integralidade, do trabalho em redes, garantido uma atenção diversificada aos usuários de álcool outras drogas. 
- Priorizar as ações dirigidas às crianças e adolescentes em situações de vulnerabilidade, haja vista a iniciação cada vez mais precoce do consumo de substâncias psicoativas e as graves repercussões do seu uso no desenvolvimento psicossocial dos jovens.

- Considerar a rede social de relacionamento da população alvo, como fatores de agravamento ou redução das condições de vulnerabilidade, isto é, levar em conta fatores de risco e de proteção, em cada contexto.

- Incentivar o trabalho de natureza interdisciplinar e enfoque intersetorial, considerando a complexidade que envolve os contextos de vida da população que vive em situação de rua, e a necessidade de ações de atenção integral aos usuários de psicoativos com tais características.

- Manter articulação permanente da rede de saúde e intersetorial visando à sensibilização dos serviços e profissionais da rede para o acolhimento com qualidade aos usuários de drogas em situação de rua.

- Garantir o alinhamento com as diretrizes da Política para Atenção Integral a Pessoas que Usam Álcool e Outras Drogas, do Plano Emergencial de Ampliação do Acesso ao Tratamento e Prevenção em Álcool e outras Drogas, do Plano Integrado de Enfrentamento do Crack, da Política Nacional de Saúde Mental, da Política Nacional de DST/AIDS, da Política de Humanização e da Política de Atenção Básica do Ministério da Saúde.

\subsection{Quais os princípios que norteiam essa prática?}

A universalidade de acesso à saúde, um dos princípios do Sistema Único de Saúde - SUS, é um dos eixos éticos que norteiam essa prática. Ao acolher um segmento populacional em situação de exclusão social, que se auto-exclui ou que é excluída da rede de serviços, o objetivo é intervir inserindo esses usuários na rede SUS e concederlhes o direito à saúde pública, funcionando como porta de entrada no sistema de saúde.

A integralidade da atenção é assegurada pela multidisciplinaridade da equipe, que com seus olhares e saberes plurais pode acolher as demandas de ordem física, psíquica e social dos usuários. A clientela atendida pelo Consultório de Rua, pelos históricos de vida e pela dificuldade de acessar e ser acessada pela rede formal acumula problemas de saúde e relevantes questões pessoais e sociais. A sobreposição de problemas acumulados vai potencializar os riscos à saúde psicossocial destes indivíduos, de maneira que a oferta de ajuda do Consultório de Rua busca reduzir os danos em diferentes vertentes, favorecendo a melhoria da qualidade de vida.

A equidade, outro princípio do SUS, que visa assegurar "mais aos que têm menos", busca dar prioridade de atenção aos grupos que vivem em contextos sócioeconômicos mais desfavoráveis, e por isso, com as piores condições de saúde geral. $\mathrm{O}$ Consultório de Rua se caracteriza como uma oferta programada na perspectiva da integralidade da saúde a um dos segmentos mais fragilizados da sociedade, atendendo assim de forma equinâme estes indivíduos.

Outro eixo ético se refere ao respeito ao modus vivendi da população atendida. Não cabe à equipe nenhuma forma de julgamento ou censura moral aos 
comportamentos dos indivíduos, seja com relação ao uso de substâncias psicoativas ilícitas, ou a condutas delinqüentes ou antagônicas à moral e costumes tidos como aceitáveis. O papel dos profissionais é exatamente o de acessar um segmento que muitas vezes está à margem da rede de saúde e social por temer o estigma e a rejeição. A aceitação de cada um destes usuários enquanto sujeitos e o respeito ao lugar que ocupam na escala social confere ao Consultório de Rua a possibilidade de construção de um vínculo de confiança, base sobre a qual se desenvolverá o trabalho.

A redução de danos é estratégia prioritária no atendimento aos usuários, respeitando seu tempo e escolha em relação ao consumo das substâncias psicoativas utilizadas, buscando reduzir os danos decorrentes sem imposição de condições rígidas para seu tratamento.

Por fim, o trabalho direcionado às crianças e adolescentes deve utilizar uma linguagem própria, intermediando a aproximação dos profissionais e a população mais jovem através de estratégias lúdicas. O uso de recursos como o teatro improvisado com bonecos de fantoches, desenhos e jogos empresta ludicidade à comunicação, funcionando como uma ferramenta de trabalho.

\subsection{Quais os objetivos do Consultório de Rua?}

Seu propósito é oferecer ao segmento de usuários de substâncias psicoativas em situação de maior vulnerabilidade a disponibilização de recursos para os cuidados básicos de saúde, atendendo-os em seus locais de permanência e encaminhando as demandas mais complexas para a rede de saúde. Nesse sentido, uma das suas funções é atuar como uma ponte para a população que está à margem do sistema de saúde e possibilitar sua inserção na rede.

Inicialmente pensada como uma estratégia dirigida apenas ao segmento de crianças e adolescentes em situação de rua, ela foi ampliada a outras faixas etárias nas mesmas condições sociais, sem perder a priorização do público infanto-juvenil.

O perfil de "'em situação de rua" engloba todos aqueles que passam grande parte do tempo no espaço público, mantendo vínculos precários com a família ou aqueles que tomaram o espaço da rua como local de moradia, visto que muitas vezes a passagem de uma condição a outra é decorrente de uma gradativa desvinculação que vai se processando pouco a pouco ao longo de meses e anos (NEIVA-SILVA; KOLLER, 2002).

A proposta do Consultório de Rua é sustentada a partir da equipe mínima, que atua fora das paredes da instituição, intervindo em ações de prevenção e cuidados de saúde, considerando o conhecimento sobre os problemas, hábitos e condutas de risco dos usuários. A equipe mínima formada por profissionais de diversas campos disciplinares permitem uma oferta de serviço na perspectiva da integralidade, buscando atender aos indivíduos em suas queixas, necessidades e demandas no âmbito biopsicossocial. Para isso procura construir uma aproximação cuidadosa no sentido de adequar as ações a serem desenvolvidas, priorizando a abordagem a partir do estabelecimento de vínculos de confiança, na busca de constituir uma interlocução singular com os usuários. Nesse sentido, a tecnologia essencial do trabalho é construída 
a partir da relação que a equipe mantém com cada indivíduo na rua, privilegiando a particularidade de cada um. Os profissionais realizam uma escuta sensível sobre a situação atual e as histórias de vida dos usuários, ajudando-os a refletir e tentar encontrar caminhos alternativos de acordo com seus desejos.

O percurso anterior dessa população em relação ao contato com as instituições de saúde e sociais muitas vezes se passou através de situações de rejeição devido ao estigma e à falta de acolhimento por parte de profissionais da rede, gerando o afastamento destes dos serviços formais. O Consultório de Rua apresenta uma proposta que procura ultrapassar essa barreira, a começar pelo fato de os profissionais se dirigirem a essa população em seu próprio espaço de vida, e abrir um campo de fala, ampliando a capacidade de subjetivação dos usuários, considerando a realidade de vida desses sujeitos.

Apesar de, muitas vezes, nos primeiros momentos a equipe ser recebida com certa desconfiança por alguns usuários, aos poucos, a regularidade da presença, a percepção da atenção qualificada e acolhedora dos profissionais vai abrindo as possibilidades de construção de um vínculo de confiança. A partir daí, a própria população passa a demandar da equipe cuidados que até então estavam relegados ao abandono. Essas demandas são "disparadas"' a partir da apresentação da proposta e dos profissionais, configurando a oferta de serviços de saúde do Consultório de Rua.

Neste sentido, constitui objetivos do dispositivo a realização de consultas, orientações, oficinas de educação em saúde, e encaminhamentos das demandas não atendidas in loco, para a rede de saúde do SUS, ações de prevenção de doenças infectocontagiosas como as doenças sexualmente transmissíveis, tuberculose, e diversos outros cuidados de problemas já instalados.

\subsection{Etapas preliminares e operacionalização do Consultório de Rua}

O mapeamento da cidade é a primeira etapa que antecede à operacionalização do Consultório de Rua, quando se procura identificar locais onde há uma maior concentração de jovens em situação de risco psicossocial e em uso de drogas. A partir da identificação dos locais mais necessitados da intervenção, a equipe escolhe as áreas prioritárias para a presença do Consultório de Rua. Outra forma complementar que auxilia a escolha das áreas é a interlocução com a rede de saúde e intersetorial, que pode sinalizar áreas mais vulneráveis onde se considera a intervenção importante para a população alvo.

A etapa seguinte é a abertura de campo. Nesta etapa se busca identificar as lideranças do grupo ou da comunidade, para que, com seu aval, a equipe possa se instalar no território sem com isso interferir de forma invasiva no seu espaço de vida. Uma vez havendo a aquiescência das lideranças, estas podem influenciar positivamente para a receptividade do trabalho pelos membros do grupo ou da comunidade em torno. Em conjunto com a comunidade, os técnicos definem um ponto fixo para estacionar a Unidade Móvel, criando uma referência de lugar e hora para os encontros periódicos.

A regularidade da presença do Consultório de Rua sempre no mesmo local e horário permitirá às pessoas manter um vínculo com os profissionais, buscando-os 
sempre que sentirem necessidade. É a partir dessa dinâmica de funcionamento que a relação de confiança vai se constituindo, estabelecendo-se de forma gradativa a aproximação da clientela, e possibilitando que os mesmos exponham seus problemas e busquem ajuda, dando início ao funcionamento cotidiano do Consultório de Rua

\subsection{A rotina do Consultório de Rua}

A rotina de trabalho do Consultório de Rua divide-se em atividades extracampo, com os contatos com a rede de saúde e intersetorial na engenharia das articulações interinstitucionais, o acompanhamento de usuários quando se fizer necessário, discussão clínica de casos, a elaboração dos diários de campo e relatórios. Além dessas, na rotina diária está prevista uma reunião que antecede a ida a campo, com duração de uma (1) hora, com a presença de coordenador do Consultório de Rua, o supervisor clínicoinstitucional e os técnicos da equipe da área a ser atendida no dia. Neste momento a equipe define quais as melhores estratégias de abordagem, um planejamento das atividades a serem realizadas no dia, configurando um processo permanente de avaliação do processo de trabalho da área. Há ainda a preparação do carro com os materiais necessários para a realização das atividades, e em seguida a equipe se desloca para a área de trabalho. O carro deve estacionar no local e horário definidos previamente nos contatos preliminares com a comunidade da área, e em casos de mudança de local é aconselhável que seja de comum acordo, se possível.

O segundo tipo de atividades são as atividades de campo, que constituem os atendimentos aos usuários no seu espaço de permanência. Os atendimentos são realizados fora do carro, este servindo como apoio para as atividades e referência institucional para os usuários. A equipe deve se colocar disponível, acessando e sendo acessada pelos usuários. Os contatos devem ser discretos e receptivos, guiados por uma postura acolhedora. Cada profissional desenvolve suas atividades planejadas e de acordo com as demandas que se apresentarem no momento. O tempo de permanência não é rígido, variando de acordo com as demandas. O período de tempo na rua, ou seja, o turno de trabalho deve ser suficiente para o desenvolvimento de atividades de rotina, como a distribuição de preservativos, a realização de oficinas de educação em saúde, atividades lúdicas, consultas clínicas e seus desdobramentos, tais como orientações e encaminhamentos. Os encaminhamentos podem ser entre os profissionais da equipe nas interconsultas, ou externos, para os serviços da rede de saúde e intersetorial. Os desdobramentos e/ou encaminhamentos externos pendentes devem ficar sob a responsabilidade do profissional contatado pelo usuário, respeitando o vínculo estabelecido com ele.

Algumas atividades estratégicas são planejadas como "disparadoras" de demandas, outras como técnicas de aproximação. Mas o planejamento prévio pode ser descartado em função de variáveis não controladas. Nesse caso a equipe deve ter flexibilidade e criatividade para se adequar ao que se apresentar ali e propor novas alternativas. $\mathrm{O}$ contexto da rua é dinâmico e a equipe deve ajustar o trabalho frente ao inesperado. 
Apesar das orientações acima, este não é um trabalho para o qual se estabelece um protocolo rígido, ou uma 'receita de como fazer'. Os Consultórios de Rua são dispositivos que têm uma estrutura viva, flexível, que deve adaptar-se a todo instante às condições que se apresentam. É um trabalho que segue o contexto mutante da rua, sempre dinâmico, que leva a equipe a incorporar uma forma de atuação também dinâmica. Por ser uma estrutura viva, ele é construído cotidianamente, adequando-se às condições dos lugares e do momento.

Embora seja desejável compor uma estrutura mínima de funcionamento para os Consultórios de Rua, e há um esforço nesse sentido, a idéia é que esse formato definido em algumas premissas não sejam elementos de engessamento do trabalho. Muito ao contrário, o que se espera é que, entre os elementos básicos que possam dar uma estrutura de funcionamento ao dispositivo, a operacionalização do Consultório de Rua mantenha como sua maior e melhor característica a oferta de um serviço que atua ao nível de uma interação, onde o eixo pelo qual se processa todo o trabalho é o que envolve profissional-usuário em uma relação inter-humana, misturando técnica, teoria e sensibilidade humana.

4.7 Como os Consultórios de Rua se articulam com o restante da rede setorial e com a intersetorialidade

Os Consultórios de Rua são equipamentos de saúde com potência para promover articulações na rede intersetorial, uma vez que, ao atuar na ponta, com um público com especificidades tão complexas, com queixas e demandas múltiplas, necessitam de aliança com outros setores para dar retaguarda aos encaminhamentos, buscando romper o isolamento do setor saúde, construindo efetivamente parcerias eficazes e resolutivas, e que de fato atendam às necessidades da população. A multidisciplinaridade da equipe pode fazer aumentar o raio da ação que se inicia na ponta para o interior da rede de saúde e de outros setores (ainda não podemos dizer que há uma 'rede intersetorial'"), desde os recursos comunitários (escolas, centros culturais, centros esportivos, associação de moradores) existentes na área de atuação do Consultório de Rua, de onde procedem os encaminhamentos feitos, acessando também os equipamentos de saúde como os PSF, UBS, CAPS, Postos de Saúde, hospitais, etc. Assim, através da equipe são articulados serviços nos diversos setores para dar consequiência aos atendimentos in loco, buscando na prática uma "engenharia", interinstitucional e intersetorial. Dessa forma, os profissionais "provocarão" os demais serviços da rede intersetorial para que acolham os usuários encaminhados pelo Consultório de Rua, dando acolhimento às demandas e resolutividade aos problemas apresentados, podendo acompanhar o fluxo de referência e contrarreferência. Com essas "'amarrações" interinstitucionais pretende-se potencializar as ações do Consultório de Rua através do enredamento/sensibilização dos profissionais dos serviços na ética de uma clínica ampliada. 
Os municípios que apresentam perfil epidemiológico para incluir este dispositivo como um equipamento de saúde para usuários de $\mathrm{AD}$ excluídos da rede, inserindo-os na rede formal de saúde, possibilitando seu acesso para cuidados relacionados aos problemas decorrentes do consumo de álcool e outras drogas.

Como um parâmetro geral, os Consultórios de Rua são indicados para municípios com população superior a 300 mil habitantes, o que deve ser visto como uma orientação flexível. 


\section{RELATO DE EXPERIÊNCIA CONSULTÓRIO DE RUA: ESTAMOS AQUI... E AÍ?}

\section{CONSULTÓRIO DE RUA: ATENÇÃO INTEGRAL ÀS CRIANÇAS E ADOLESCENTES EM SITUAÇÃO DE RUA E QUE FAZEM USO DE ÁLCOOL E OUTRAS DROGAS}

Autora: Valéria Cristina da Silva ${ }^{1}$

Equipe: André Albuquerque,Cícera Luana, Elencilda Pessoa, Marcos Perazzo, Renata Martins, Wilson Gonçalves

Colaboradores: Ana Vigarani, Cínthia Galiza

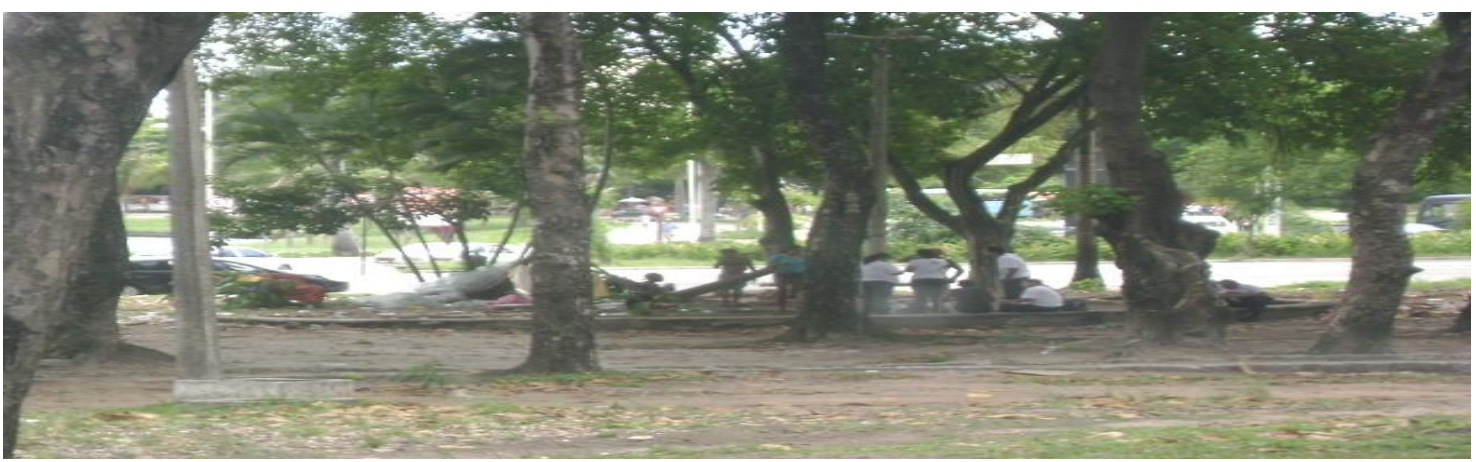

O município de João Pessoa/PB, através da Secretaria de Saúde, vem ampliando e fortalecendo as ações no tocante às políticas públicas voltadas para Atenção Básica em Saúde e Saúde Mental, de acordo com as diretrizes do SUS, com base nos pressupostos da Reforma Psiquiátrica, da Política Nacional DST/AIDS, Política Nacional de Saúde Mental e Política de Atenção Integral a Usuários de Álcool e outras Drogas. Nesta perspectiva e buscando privilegiar uma linha de cuidado integral, aliada a uma prática inovadora de atenção aos jovens em situação de rua e que fazem uso de álcool e outras drogas, o Consultório de Rua (CR): Estamos Aqui... e Aí! foi implantado em março de 2010, como parte integrante do Plano Emergencial de Ampliação do Acesso ao Tratamento e Prevenção em Álcool e outras Drogas (PEAD) em João Pessoa. Trata-se de uma equipe multiprofissional formada por 03 redutores danos, 01 assistente social, 01 psicólogo e 01 enfermeira, que faz abordagem nos logradouros públicos, praças, casas abandonadas dentre outros, baseado na estratégia de redução de danos e na redução dos agravos à saúde decorrentes do uso/abuso de substâncias psicoativas.

A primeira abordagem ocorreu no Parque Sólon de Lucena, próximo ao Cassino da Lagoa, localizado no centro da cidade, onde foi abordado um grupo de adolescentes e jovens adultos que estavam sob efeito de thiner, pés descalços, uns deitados numa rede, outros deitados em um colchão no chão. Na oportunidade, o CR apresentou-se ao grupo e perguntou se gostariam de receber assistência em saúde e de participar de oficina de capoeira. O fato de compor a equipe um redutor de danos 
capoeirista permtiu que, surpreendentemente, a receptividade foi de imediato e logo depois alguns já começaram a demonstrar as habilidades para o jogo de capoeira. O interessante foi que um dos meninos falou que só a aproximação e preocupação da equipe com sua saúde já propiciou a conquista da confiança do grupo. Outro jovem comentou: "as pessoas não costumam se aproximar da gente, pelo contrário, têm medo". Ficou agendado o retorno da equipe para o dia seguinte. A equipe constatou a necessidade de um dentista, pois a queixa de muitas dores de dente era constante. A idéia foi levar o referido profissional para o espaço de rua, no sentido de formar o vínculo antes de levá-los para o Centro de Especialidades Odontológicas (CEO). Assim aconteceu. Houve surpresa da equipe, pois no dia marcado para a condução dos meninos para o CEO, eles haviam levado colegas que não estavam presentes no dia do agendamento, demonstrando com esse ato, o sentimento de solidariedade para com o restante do grupo, e não preocupação com seus próprios problemas. O êxito obtido com o dentista motivou a adoção da mesma estratégia para com o atendimento médico, obtendo a equipe resultado satisfatório. Uma importante particularidade é o fato de que a população era de meninos, meninas, adolescentes e jovens adultos, sendo perceptível o uso do Thinner, portando, a maioria, um pano sobre o ombro onde ficavam todo o tempo inalando. Numa breve conversa, soube-se que entre eles haviam garotos com história de abandono, abuso sexual e violência familiar, alegando, por isso, estarem nas ruas. Estiveram presentes relatos como: "aqui na rua uns defendem os outros" ou "nós passamos por muita humilhação, as pessoas não querem saber da gente". Percebeu-se a procura por amparo uns aos outros, embora quem comandasse fosse o líder, pessoa de maior confiança para os meninos, que relataram não deixar faltar comida para ninguém. A equipe do CR sabia ter que conquistar o respeito e a confiança da liderança do grupo, para poder prosseguir o desenvolvimento do trabalho.

O vínculo foi acontecendo aos poucos, com o cumprimento dos horários da assistência e atividades com os jovens, respeitando a própria decisão de cada um em querer ou não os cuidados do Consultório de Rua, e sempre com a autorização do líder. Com a realização das visitas diárias, a demanda de atenção foi se ampliando, e a cada dia o número dos jovens foi aumentando, além de passar o atendimento aos adultos que se encontravam também em situação de rua e que são referências para os meninos. Com o passar do tempo, as informações cedidas e a própria observação do cotidiano da criança e do adolescente em situação de rua, a equipe constatou que o grupo vivenciava situações conflitantes e de violência, mas que, mesmo assim, os jovens se sentiam acolhidos pelos "irmãos de rua", onde eles desenvolvem estratégias de sobrevivência juntos. Na verdade, são invisíveis para a sociedade e sabem disso; por isso, procuram pertencer a algo, buscam aceitação, ainda que essa valorização venha daqueles que se encontram no espaço de rua. Foram encontrados jovens com vínculo familiar, mas que passam o dia nas ruas junto com aqueles com vínculo familiar interrompido ou com os que estão em processo de ruptura familiar, com breves saídas de casa. O grupo considera-se como "o grupo do thinner", não permitindo crack. Diziam não se misturar com "a turma do crack", apesar de algumas vezes a equipe tê-los visto com um casal usuários de crack. 
Dessa forma, a ansiedade e as expectativas de como deveriam ser as abordagens na aproximação e o estabelecimento do vínculo passaram, aos poucos, a ser naturais, na medida em que cada um aceitava participar das atividades propostas e da receptividade quanto à assistência em saúde. Foi possível conhecer como se dão os relacionamentos, a divisão do mesmo espaço, o que pensa e deseja o grupo. A aproximação com a dinâmica de vida dos meninos em situação de rua acaba, de alguma forma, fortalecendo os profissionais do CR, sua habilidade no trato e no manejo, estando ou não os meninos sob efeito de substâncias psicoativas.

Após o desenvolvimento do trabalho de campo, evidenciamos a necessidade de cuidar da equipe do CR, tendo em vista a complexidade e toda a dinâmica que envolve os meninos em situação de rua: ora os jovens estão juntos dividindo o mesmo espaço, ora envolvidos em intensas brigas, o que faz eles se dispersarem, ora apreendidos pela polícia por terem cometidos atos infracionais, ora machucados, ora desaparecidos, ora agressivos, ora receptivos, ora buscam ajuda para voltarem para casa, ora afirmam gostarem de morar nas ruas, ora presenciam momentos de tristeza ao relatarem estarem sendo perseguidos por inimigos, dentre outras situações. Sendo assim, além de avaliarmos o que foi realizado em campo e refletirmos a respeito, passamos a promover Oficinas Cuidando do Cuidador, com encontros semanais, onde tudo o que é vivenciado nas ruas, as questões emocionais que trazem angústia, desânimo, desmotivação, são temas trabalhados, além da própria convivência entre o grupo

Os primeiros resultados são frutos de um trabalho que vem sendo desenvolvido ao longo de seis meses, com muita dedicação e presteza. Falar em resultados remete a equipe a pensar e refletir sobre os aspectos que considera relevantes no desenvolvimento do Consultório de Rua e que considera como merecedores de destaque: mudanças nos juízos de valores da equipe do $\mathrm{CR}$, que relata outro olhar para com as crianças e adolescentes em situação de rua, após vivenciar a experiência com eles. Conforme citação de um redutor de danos: "antes do CR, o que me enchiam os olhos eram as vitrines das lojas; hoje, o que me enchem os olhos são os meninos que ficam nas calçadas das lojas". A equipe verifica o quanto a capoeira como estratégia de aproximação foi surtindo efeito, uma vez que o interesse nas rodas de capoeira é de imediato, independente de sexo e idade. O entusiasmo está em tocar nos instrumentos, cantar e aprender a fazer os movimentos. É nesse envolvimento, todos em roda, que as mensagens educativas em saúde e preventivas em relação às DSTs/ Aids foram e são trabalhadas. A arte-terapia envolvendo desenho, pintura, colagem, oficinas de histórias é utilizada para a socialização, o trabalho de temas de cuidados de saúde, do uso de substâncias psicoativas e cidadania, bem como para o fortalecimento do vínculo com a equipe.

Foi constatado que as ações de assistência básica em saúde realizadas in loco (procedimentos de enfermagem, escuta psicológica, atendimento médico e com dentista), possibilitaram a adesão do grupo aos demais serviços de saúde, conforme necessidade da demanda: tratamento HIV/AIDS; encaminhamento e acompanhamento hospitalar e atendimento pré-natal; encaminhamento a ginecologista, oftalmologista, tratamento odontológico, avaliação com clínico geral; realização de exames laboratoriais, acompanhamento na solicitação do cartão SUS, encaminhamento para 
obtenção de prótese dentária. Outras questões vislumbradas pela equipe foram as manifestações de mudanças no comportamento de alguns jovens, ao longo dos seis meses: tomar banho no dia da consulta médica, procurar evitar fazer uso do thinner quando vão ao dentista, lavar as roupas para se vestir. Também se pode mencionar o vínculo com a equipe quando o grupo informa sobre as outras áreas onde costumam se concentrar, quando solicita atendimento em enfermagem, quando estão com ferimentos ou para irem ao dentista quando estão com dor de dente. Alguns deles falam sobre seus desejos, necessidades e sonhos adormecidos, reafirmando assim a importância do estabelecimento do vínculo como o maior aliado na continuidade da assistência.

A equipe pôde quantificar tudo o que seria considerado como aprendizado com a vivência no Projeto. Entretanto, dimensionar o que não é mensurável é o maior desafio! Partindo do desconhecido, cada um da equipe foi se encantando com a proposta. Descobriu a grandeza e a riqueza de garantir o espaço da fala do outro. Que ao desvendar o prazer da escuta, ao sentir que, mesmo por um instante, esse outro permite saber o que muitas vezes não foi revelado a ninguém. É o estabelecimento da confiança, através do respeito, tão primordial para qualquer tipo de relacionamento, que está posto no desenvolvimento do CR. O que se vê e se escuta, pode ser esquecido; mas é o que se sente com o que se vê e o que se ouve, que fica gravado no âmbito do todo ser. O sentir não é só o da equipe em relação aos jovens, mas o que as crianças e adolescentes em situação de rua sentem com a atenção e cuidados levados a eles, já que cada um traz consigo uma história de experiências fortes e presentes marcada pelos mais diversos tipos de violência. Fica o registro de A.W., que investiu duas semanas do seu tempo confeccionando um presente, utilizando a técnica do origami, como gesto de gratidão à equipe do CR, pelo que recebeu de assistência em Saúde no espaço de rua e nos demais serviços da rede do município. A equipe aprendeu que, acreditar no que se faz é o maior agente motivador de superação dos obstáculos e dificuldades vivenciadas nas ações do Consultório de Rua.

\section{RECOMENDAÇÕES}

O Projeto Consultório de Rua poderá ser desenvolvido com êxito em qualquer lugar, desde que a equipe se identifique com a causa, com o modelo de atenção focado no sujeito, que tenha clareza política sobre a proposta e o apoio da gestão. Que haja decisão política do município, sobretudo no processo do cuidado integral, com práticas humanizadas à população em situação de rua. 


\section{6 - Bibliografia}

BAUMAN, Z. Globalização: as conseqüências humanas. Tradução Marcus Penchel. Rio de Janeiro: Jorge Zahar, 1999. 145 p.

BUCHER, R. Drogas e sociedade nos tempos da AIDS. Brasília: Universidade de Brasília, 1996. $131 \mathrm{p}$.

BURSZTYN, M. Da pobreza à miséria, da miséria à exclusão: o caso das populações de rua. IN: No meio da rua: nômades, excluídos e viradores. Rio de Janeiro: Garamond, 2000, p. 27-52.

BRASIL. Ministério da Saúde. Os Centros de Atenção Psicossocial [completar]. Disponível em www.saude.gov.br/saudemental.

BRASIL. Ministério da Saúde. A política do Ministério da Saúde para Atenção Integral a Usuários de Álcool e outras Drogas. Disponível em www.saude.gov.br/saudemental.

CARVALHO, D. B. B. O consumo de drogas por crianças e adolescentes em situação de rua no Distrito Federal: relatos de experiências vividas. IN: CARVALHO, D. B. B.;

SILVA, M. T. (Orgs.). Prevenindo a drogadição entre crianças e adolescentes em situação de rua: a experiência do PRODEQUI. Brasília: MS/COSAM; UnB/PRODEQUI; UNDCP, 1999. p. 51-64.

CASTELLS, M. O surgimento do quarto mundo: capitalismo informacional, pobreza e exclusão social. IN: Fim de milênio. São Paulo: Paz e Terra, 1999. p. 95-201.

Delgado, P. G. G. Drogas: o desafio da saúde pública. In ACSELRAD, G. (ORG.) Avessos do Prazer: drogas, aids e direitos humanos. 2.ed. Rio de Janeiro: Editora Fiocruz, 2005. pp.165-182

DIOS, V. C. Droga, família, escola e o grupo de pares no processo de socialização de crianças e adolescentes em situação de rua. IN: CARVALHO, D. B. B.; SILVA, M. T. (Orgs.). Prevenindo a drogadição entre crianças e adolescentes em situação de rua: a experiência do PRODEQUI. Brasília: MS/COSAM; UnB/PRODEQUI; UNDCP, 1999. p. 79-89.

LIPOVETZKY, G. Os tempos hipermodernos. Tradução Mário Vilela. São Paulo: Barcarolla, 2004. 127 p.

NEIVA-SILVA, L.; KOLLER, S. H. A rua como contexto de desenvolvimento. IN: 
LORDELO, E. R.; CARVALHO, A. M.; KOLLER, S. H. (Orgs.) Infância brasileira e contextos de desenvolvimento. São Paulo: Casa do Psicólogo; Salvador: EDUFBA, p. 205-230, 2002.

NERY FILHO, A. "La vie dans la marginalité ou la mort dans l'instituiton": étude sur quatre groups d'enfants et d'adolescents vivant de la rue a Salvador de Bahia (Bresil). These (Doctorat en Sociologie e Sciences Sociales) - Université Lumière Lyon 2, Faculté d'Antropologie et de Sociologie. 1993. Inédito. 584 p.

NOTO, A. R.; GALDURÓZ J. C. F.; NAPPO, S.A.; FONSECA, A. M.; CARLINI, E. A. III Levantamento nacional sobre o uso de drogas entre crianças e adolescentes em situação de rua de seis capitais brasileiras. São Paulo: Escola Paulista de Medicina, 1993. $97 \mathrm{p}$.

NOTO, A. R.; GALDURÓZ J. C. F.; NAPPO, S.A.; FONSECA, A. M.; CARLINI, E. A. IV Levantamento nacional sobre o uso de drogas entre crianças e adolescentes em situação de rua de seis capitais brasileiras. São Paulo: Escola Paulista de Medicina, 1997. $120 \mathrm{p}$.

NOTO, A. R.; GALDURÓZ J. C. F.; NAPPO, S.A.; FONSECA, A. M.; CARLINI, E. A. Levantamento nacional sobre o uso de drogas entre crianças e adolescentes em situação de rua nas 27 capitais brasileiras. Escola Paulista de Medicina, São Paulo, (CEBRID/SENAD), 2003. 246 p.

NOTO, A. R et al. Catálogo de Instituições que assistem Crianças e Adolescentes em Situação de Rua em 27 Capitais Brasileiras. São Paulo: CEBRID, 2004. p. 85-90.

OLIVEIRA, M.G.P.N. Consultório de rua: relato de uma experiência. Dissertação (mestrado). Universidade Federal da Bahia. Instituto de Saúde Coletiva. Salvador, Bahia. 2009. 151p.

PEAD - Plano Emergencial de Ampliação do Acesso ao Tratamento e Prevenção em Álcool e outras Drogas no Sistema Único de Saúde - SUS (PEAD 2009-2010), Portaria $\mathrm{n}^{\mathrm{o}} 1.190$, de 4 de junho de 2009.

PIEC - Plano de Enfrentamento do Crack, 2010. Decreto nº 7.179, de 20 de maio de 2010.

TOTUGUI, M.L.; GIOVANNI, M.D.; CORDEIRO. F.; DIAS, M.K.; DELGADO, P. G. G. “Álcool e outras Drogas como Desafio para a Saúde e as Políticas Intersetoriais contribuições para a IV Conferência Nacional de Saúde Mental - Intersetorial" In Vasconcelos, E. M. Desafios Políticos da Reforma Psiquiátrica Brasileira. Editora Hucitec. São Paulo: 2010. pp. 93 - 113. 
VARANDA, W \& ADORNO, RCF (2004) Descartáveis urbanos: discutindo a complexidade da população de rua e o desafio para políticas de saúde. Saúde e Sociedade v.13, n.1, p.56-69, jan-abr 2004.

LINK: http://www.scielo.br/pdf/sausoc/v13n1/07.pdf

WACQUANT, L. Os condenados da cidade: estudos sobre marginalidade avançada. $2^{\mathrm{a}}$. ed. Tradução João Roberto Martins Filho et al. Rio de Janeiro: Revan; FASE, 2001. Set. 2005. 224 p.

Walter Varanda. Liminaridade, bebidas alcoolicas e outras drogas:funções e significados entre moradores de rua. 2009. Tese (Doutorado em Programa de PósGraduação em Saúde Pública) - Faculdade de Saude Publica /USP. 


\section{7 - Endereços para Contato e Informações}

\subsection{Ministeriais}

\section{- MINISTÉRIO DA SAÚDE}

$\underline{\text { www.saude.gov.br }}$

Informações gerais sobre o SUS, programas de saúde e links importantes.

\section{- DISQUE SAÚDE MINISTÉRIO DA SAÚDE 0800611997}

Serviço telefônico gratuito para esclarecimentos à população em geral.

\section{- DEPARTAMENTO DE DST, AIDS E HEPATITES VIRAIS - MINISTÉRIO DA SAÚDE www.aids.gov.br}

Informações gerais sobre as doenças sexualmente transmissíveis, locais para a realização do teste anti-HIV, publicações e materiais educativos e instrucionais.

\section{- DEPARTAMENTO DE ATENÇÃO BÁSICA/DAB/SAS}

http://www.saude.gov.br/dab

Ações de saúde, no âmbito individual e coletivo, que abrangem a promoção e a proteção da saúde, a prevenção de agravos, o diagnóstico, o tratamento, a reabilitação e a manutenção da saúde. Responsável por desenvolver mecanismos de controle e avaliação dos serviços de atenção básica e prestar cooperação técnica a estados, municípios e Distrito Federal na organização de ações de atendimento básico, como o Programa Saúde da Família (PSF), Saúde Bucal, Diabetes e Hipertensão Arterial, Alimentação e Nutrição, Gestão e Estratégia, Avaliação e Acompanhamento.

Edifício Premium SAF Sul - Quadra 2 - Lotes 5/6 Bloco II - Subsolo - CEP: 70.070600 Brasília - DF - Telefone: (61) 3306-8044

Email: DAB@saude.gov.br

- COORDENAÇÃO GERAL de Saúde Mental, Álcool e outras Drogas/DAPES/SAS/MS www.saude.gov.br/saudemental

Departamento de Ações Programáticas Estratégicas - DAPE

Secretaria de Atenção à Saúde - SAS

Coordenador: Pedro Gabriel Godinho Delgado 
Setor de Administrativo Federal Sul (SAF Sul)

Trecho 2, Bloco F, Edifício Premium, Torre II

SALA 13

CEP 70070-600Brasília/DF

fone (61) 3306-8140/8141/8142/8243/8144

E-mail: saudemental@saude.gov.br

\subsection{Coordenações Estaduais de Saúde Mental}

\begin{tabular}{|c|c|c|c|c|}
\hline $\mathbf{N}^{\mathbf{o}}$ & UF & $\begin{array}{c}\text { NOME } \\
\text { COORDENADOR }\end{array}$ & TELEFONES & EMAIL \\
\hline 1 & $\mathrm{AC}$ & $\begin{array}{l}\text { Ximena Luisa Catalan } \\
\text { Pavez }\end{array}$ & (68) $3222-8453$ & smental.dabs@ac.gov.br; \\
\hline 2 & AL & Berto Gonçalo da Silva & (82) 3315-1687 & $\begin{array}{l}\text { prosam@saude.al.gov.br; } \\
\text { bertogoncalo@saude.al.gov.br; }\end{array}$ \\
\hline 3 & $\mathrm{AM}$ & $\begin{array}{l}\text { Maria de Lourdes Ribeiro } \\
\text { Siqueira }\end{array}$ & $\begin{array}{l}\text { (92) 3643-6300/6484 } \\
\text { Ramal } 6414\end{array}$ & saudemental@saude.am.gov.br; \\
\hline 4 & $\mathrm{AP}$ & Suzana de Oliveira Correia & (96) 33121516 & $\begin{array}{l}\text { suziverner@hotmail.com; } \\
\text { pena@unifap.br }\end{array}$ \\
\hline 5 & BA & Iordan Gurgel & $\begin{array}{l}\text { (71) } 3115-8421 / 4284 / \\
4382\end{array}$ & $\begin{array}{l}\text { saudemental@saude.am.gov.br; } \\
\text { saudemental.ba@gmail.com; }\end{array}$ \\
\hline 6 & $\mathrm{CE}$ & Marcelo Fialho & (85) $3101-5276$ & $\begin{array}{l}\text { cosame@saude.ce.gov.br; } \\
\text { saudementalceara@gmail.com }\end{array}$ \\
\hline 7 & DF & $\begin{array}{l}\text { Ricardo de Albuquerque } \\
\text { Lins }\end{array}$ & $\begin{array}{l}\text { (61) } 3346.6422 \text { ISM } \\
3399-3910\end{array}$ & gesam.sesdf@yahoo.com.br; \\
\hline 8 & ES & $\begin{array}{l}\text { Inêz Maria Antunes Paes } \\
\text { Torres }\end{array}$ & (27) $3137-2365$ & $\begin{array}{l}\text { ineztorres@saude.es.gov.br; } \\
\text { smental@saude.es.gov.br }\end{array}$ \\
\hline 9 & GO & $\begin{array}{l}\text { Celene Santana Oliveira } \\
\text { (Responsável) }\end{array}$ & (62) $3201-4523$ & $\begin{array}{l}\text { spais.aps@saude.go.gov.br; } \\
\text { smentalgo@hotmail.com; }\end{array}$ \\
\hline 10 & MA & Rui Cruz & $\begin{array}{l}\text { (14 AS 19hs) (98) 3218- } \\
8729\end{array}$ & saudemental@saude.ma.gov.br; \\
\hline 11 & MG & Marta Elizabete de Souza & $\begin{array}{l}(31) 3247-3829 / 3247- \\
3830\end{array}$ & saudemental@saude.mg.gov.br \\
\hline 12 & MS & Míriam Sengui & $\begin{array}{l}\text { (67) } 3318-1738 / 1650 / \\
33051664\end{array}$ & sdmental@saude.ms.gov.br; \\
\hline 13 & MT & $\begin{array}{l}\text { Áurea Assis Lambert } \\
(02 / 08)\end{array}$ & $\begin{array}{l}(65) 3613- \\
5469 / 5339 / 5340\end{array}$ & coapre.mt@gmail.com \\
\hline 14 & PA & $\begin{array}{l}\text { Rodolfo Valentim Carvalho } \\
\text { do Nascimento }\end{array}$ & (91) 4006-4304 / & saudementalsespa@yahoo.com.br \\
\hline 15 & $\mathrm{~PB}$ & Ursula PatrÍcia Neves Leite & (83) 3218-7325 & saudemental@saude.pb.gov.br; \\
\hline 16 & $\mathrm{PE}$ & Marcela Lucena & (81)31816182/6032 & $\begin{array}{l}\text { gasam.saude@hotmail.com; } \\
\text { programamaisvida@yahoo.com.br; } \\
\text { marcelalucena2005@yahoo.com.br }\end{array}$ \\
\hline 17 & PI & $\begin{array}{l}\text { Gisele Martins do } \\
\text { Nascimento }\end{array}$ & (86) 3216-3562 & saudemental@saude.pi.gov.br; \\
\hline 18 & PR & $\begin{array}{l}\text { Salette Maria Revoredo } \\
\text { Pugsley }\end{array}$ & (41) 3330-4526/4485 & $\begin{array}{l}\text { saudemental@sesa.pr.gov.br; spp- } \\
\text { sesa@ sesa.pr.gov.br }\end{array}$ \\
\hline 19 & $\mathrm{RJ}$ & Marcos de Miranda Gago & $\begin{array}{l}\text { (21) } 23333885 / 2333- \\
3905 /\end{array}$ & $\begin{array}{l}\text { smental@ saude.rj.gov.br; } \\
\text { saude.mental@saude.rj.gov.br }\end{array}$ \\
\hline 20 & $\mathrm{RN}$ & $\begin{array}{l}\text { Liege Uchoa Azevedo de } \\
\text { Araújo }\end{array}$ & (84) $3232-2461$ & $\begin{array}{l}\text { saudemental@rn.gov.br; } \\
\text { rnsaudemental@gmail.com; }\end{array}$ \\
\hline 21 & RO & $\begin{array}{l}\text { Regina Fatima Correia } \\
\text { Lima }\end{array}$ & $\begin{array}{l}\text { func. 7h ás 13h) - (69) } \\
3216-5284-5255\end{array}$ & rondoniamental@gmail.com; \\
\hline
\end{tabular}




\begin{tabular}{|c|c|c|c|c|}
\hline 22 & RR & $\begin{array}{l}\text { Maria da Conceição } \\
\text { Teixeira da Silva }\end{array}$ & (95) 2121-0581 / 0576 & saudementalrr@gmail.com; \\
\hline 23 & RS & $\begin{array}{l}\text { Patricia Bianchessi } \\
\text { Domingues }\end{array}$ & (51) $3288-5909 / 5908$ & $\begin{array}{l}\text { saudemental@ saude.rs.gov.br; } \\
\text { patricia- } \\
\text { domingues@saude.rs.gov.br }\end{array}$ \\
\hline 24 & $\mathrm{SC}$ & Elisia Puel & $\begin{array}{l}\text { (48) 3212-1689 (func. } \\
13 \mathrm{~h})\end{array}$ & saudemental@ saude.sc.gov.br; \\
\hline 25 & SE & $\begin{array}{l}\text { Ana Raquel Santiago de } \\
\text { Lima }\end{array}$ & (79) $3226-8341$ & $\begin{array}{l}\text { saude.mental@ saude.se.gov.br; } \\
\text { ana.lima@ saude.se.gov.br; } \\
\text { sony.petris@ } \text { saude.se.gov.br }\end{array}$ \\
\hline 26 & SP & $\begin{array}{l}\text { Luizemir Wolnei Carvalho } \\
\text { Lago }\end{array}$ & (11) $3066-8224$ & $\begin{array}{l}\text { lwolney@ saude.sp.gpv.br; } \\
\text { gte@ saude.sp.gov.br }\end{array}$ \\
\hline 27 & TO & Domingos de Oliveira & $\begin{array}{l}\text { (func: } 14 \text { as } 18 \mathrm{Hs} \text { ) (63) } \\
3218-3246\end{array}$ & $\begin{array}{l}\text { gab.saude@palmas.to.gov.br; } \\
\text { s.mental@saude.to.gov.br; }\end{array}$ \\
\hline
\end{tabular}

\subsection{Projetos de Consultórios de Rua apoiados pelo Ministério da Saúde}

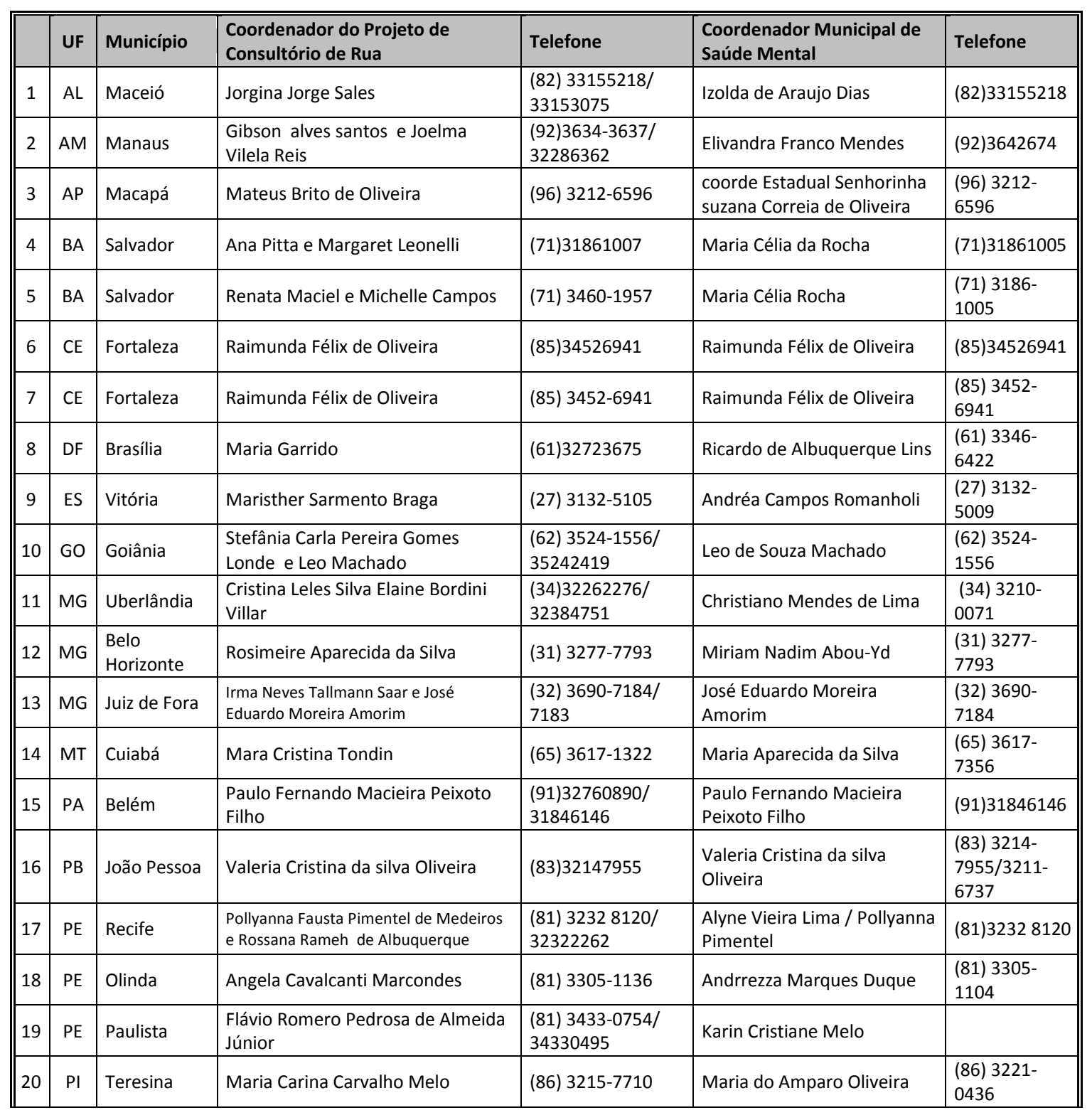




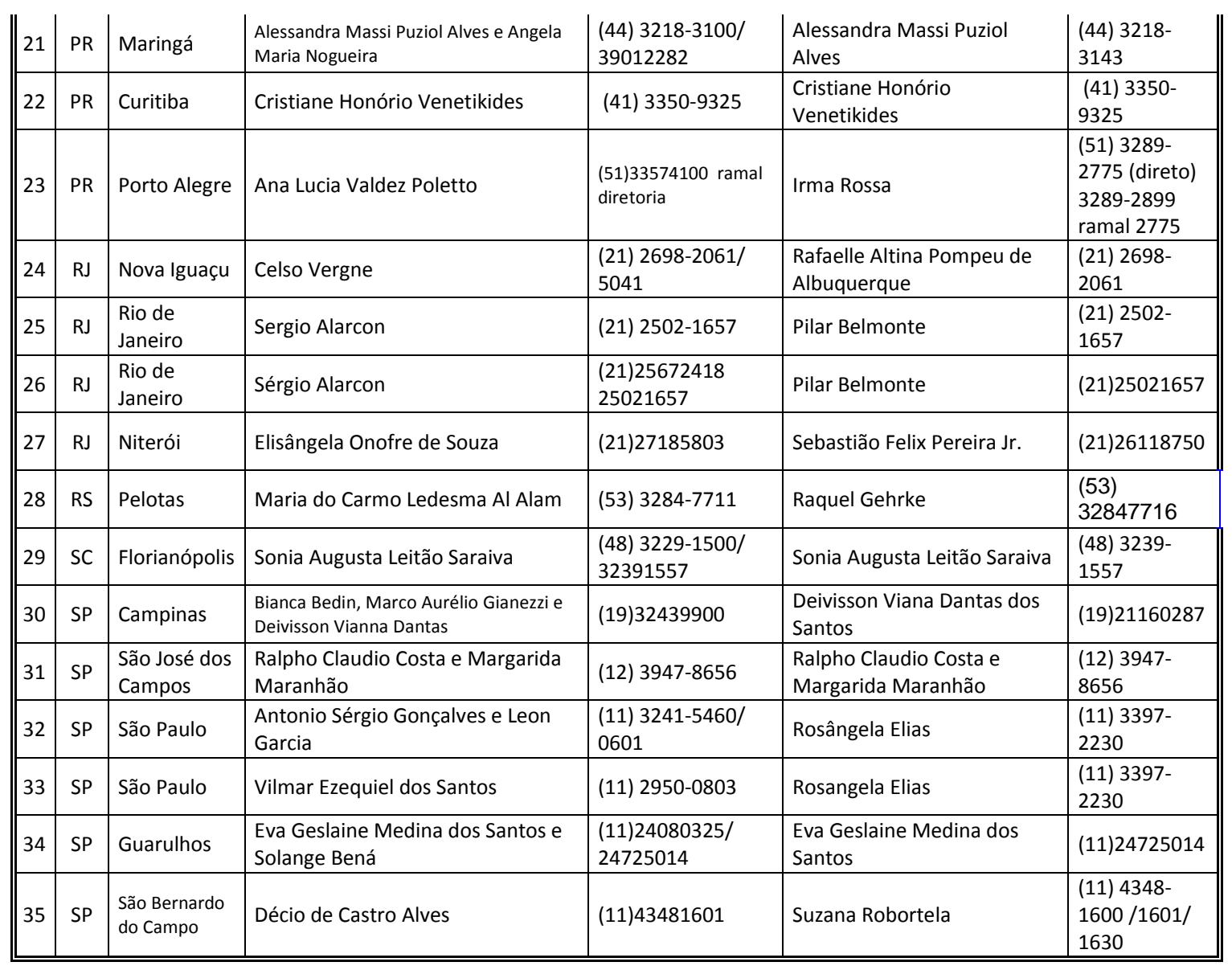


$8-$ Anexos

\section{ANEXO 1}

\section{Oficina Nacional de Projetos de Consultório de Rua - Relatório Final}

Brasília, 10 de fevereiro de 2010

\section{I - Apresentação}

Dando continuidade às diretrizes do Plano Emergencial de Acesso ao Tratamento para Usuários de Álcool e outras Drogas (PEAD - 2009/2010), que institui diversas ações como desafios da atenção à pessoa do usuário de álcool e outras drogas em situação de rua, principalmente crianças, adolescentes e jovens, o Ministério da Saúde incentiva a implantação de Consultórios de Rua.

Posteriormente à seleção dos projetos, foi realizada a I Oficina Nacional de Projetos de Consultório de Rua, em Brasília, com apoio da Organização Panamericana de Saúde, com o objetivo de desenhar uma moldura mínima para a sistematização do funcionamento da prática. Estiveram presentes coordenadores e representantes dos 14 projetos selecionados, que se tornariam referências nacionais.

II - Primeiro momento

A Oficina foi aberta com um painel sobre os objetivos do Consultório de Rua. Enquanto novo dispositivo da rede de saúde voltado para o enfrentamento do estigma, o fortalecimento do direito de acesso ao tratamento e da qualificação das redes de saúde, adoção de estratégias de redução de danos e reconhecimento dos determinantes sociais de vulnerabilidade, risco e padrões de consumo, o Consultório de Rua deve entrar na lógica dos serviços substitutivos do SUS e objetivar:

$\checkmark$ Ações integrais de prevenção e promoção da saúde, sob a lógica da redução de danos;

$\checkmark$ Promover ações que favoreçam a construção e o resgate da cidadania;

$\checkmark$ Prevenção de DST/AIDS/Hepatites Virais;

$\checkmark$ Realizar ações de redução de danos;

$\checkmark$ Promover uma rede de apoio;

$\checkmark$ Facilitar o acesso á rede.

Segundo a Coordenação de Saúde Mental do Ministério da Saúde, fenômenos como o grave cenário epidemiológico de consumo, a cultura de exclusão familiar e social da população usuária de álcool e outras drogas em situação de rua, o distanciamento histórico com os serviços da rede de saúde justificam o desenvolvimento de técnicas e práticas mais amplas e territorializadas, como o Consultório de Rua.

Além disso, o baixo acesso aos serviços de saúde está associado ao fato de que, a maioria das ofertas de cuidados apresenta modelos de atenção baseados na abstinência e na internação. Trata-se de uma imposição responsável pela precária demanda por ajuda, bem como pela baixa aderência aos modelos de tratamento existentes, de uma 
população altamente vulnerável e em situação de riscos, que se encontra seja com dificuldades para paralisar ou moderar o uso, seja sem desejo para fazê-lo.

Foi realizado um panorama do consumo prejudicial de substâncias psicoativas no país, contextualizado por uma visão multidimensional: o usuário, a droga e os aspectos sócio-culturais. Apesar da ausência de pesquisa sobre o número de usuários de crack, houve um consenso do grupo quanto à grande prevalência de uso de crack pela população infanto-juvenil em situação de rua, e a necessidade de intervenções específicas e diferenciadas.

O Consultório de Rua deve ter como referenciais: a singularidade do sujeito, a integralidade do cuidado, a lógica da Redução de Danos, a atuação no território do usuário, o respeito ao modo de viver do sujeito, a intersubjetividade, a cidadania e direitos humanos, o acolhimento e vínculo e, por fim, a intersetorialidade nas ações.

III - Segundo momento

Foi realizada uma exposição acerca da Experiência do Consultório de Rua de Salvador, com relato de importantes características, principalmente sobre o que motivou sua criação, tais como: saída precoce das crianças e adolescentes para fugir de situações de abuso e violência e miséria; busca de alívio de tensões e por ajuda financeira; duplo sofrimento e risco dentro e fora de casa; dramática situação do "lugar nenhum" ou "sem lugar"; falta de alcance e frustração diante da oferta de um modelo de atenção baseado apenas na abstinência; demanda por uma clínica da rua e em movimento com necessidade de novo setting terapêutico, desterritorializado e com tecnologias livres, baseadas na abordagem do vínculo e do acolhimento.

\section{IV - Terceiro momento}

Alguns aspectos necessários à implantação do CR foram abordados, enquanto elementos estruturantes, como:

$\checkmark \quad \mathrm{O}$ atendimento deve ser realizado por uma equipe multiprofissional, em seus locais de permanência. O vinculo é de extrema importância para a identificação e retaguarda da equipe, influenciando na receptividade da população. A abordagem feita pela equipe deve ser pela via da saúde e da cidadania. O consumo de drogas deve ser compreendido e abordado como uma via secundária. A equipe é a principal tecnologia do Consultório de Rua - assistente social, motorista agente de saúde, médico generalista, psicóloga, redutores de danos.

$\checkmark$ Deve haver um papel fundamental de articulador político, que tenha identidade com o usuário, facilitador das primeiras abordagens. Todos os técnicos deverão procurar construir esse lugar. Os profissionais são sujeitos e atores das práticas tanto quanto o usuário.

$\checkmark$ A equipe precisa ser cuidada para que não “esmoreça”. É preciso construir mecanismos de qualificação e de cuidados contínuos com a equipe - por exemplo, mobilização para lidar com a complexidade, o inesperado, a impotência, a vulnerabilidade física, psíquica e social, a subjetividade e as situações imensuráveis. 
$\checkmark$ Trata-se de um modelo de assistência que requer do profissional: flexibilidade, relativização, negociação do modelo. A oferta de serviço deve estar adaptada às especificidades da população. É fundamental a escuta sensível.

$\checkmark$ Há a necessidade de abertura para o estabelecimento de aquiescência com o tráfico para que o Consultório de Rua, dispositivo da saúde, possa circular na área. É preciso se considerar a relação no espaço da rua entre o usuário e o traficante, e as ofertas paralelas estabelecidas, inclusive antes da saúde se apresentar.

$\checkmark$ A aparência física da equipe pode servir, muitas vezes, como barreira de acesso e aceitação. É preciso uma aproximação de identidade, da equipe com a população atendida.

$\checkmark$ Postura não moralista e isenta de julgamento no tocante à diversidade da população presente - prostitutas, pequenos traficantes, travestis, e outros.

$\checkmark$ Desenvolvimento da noção de território. Trata-se de um trabalho dentro do espaço aberto, de um território que é fora, e que é um território subjetivo, para além do espaço geográfico.

$\checkmark$ As intervenções devem estar baseadas na lógica da Redução de Danos, para que seja facilitada a aproximação da equipe com a população.

$\checkmark$ Há uma diversidade de características da população alvo, conforme cada região. Na pratica não há como priorizar somente as crianças e os adolescentes. Haverá uma demanda por parte da população adulta demanda, pois eles estarão também habitando o local, inclusive liderando o mesmo. Eticamente a equipe não pode se privar dessa demanda.

$\checkmark$ Possíveis atividades a serem desenvolvidas: Prevenção das DST/AIDAS/Hepatites Virais; demonstração do uso seguro que diminua os riscos e danos à saúde; distribuição de cartilhas informativas; oficinas de educação, de jogos, de dança, de música, de arte, de contagem e narrativa de histórias e de esporte.

$\checkmark$ Oferta de atendimento médico, psicológico e social, com encaminhamento, se for o caso e se o usuário permitir, à rede SUS e SUAS.

$\checkmark$ Identificação das áreas prioritárias para a intervenção.

$\checkmark$ Mapeamento da cidade, abertura de campo, observação sobre a dinâmica do lugar, contatos preliminares com lideranças locais (inclusive com o traficante da área).

$\checkmark$ Articulação com a Atenção Básica (NASF, ESF, SAMU), com o CAPS AD e outros serviços da rede de saúde e ONGs.

$\checkmark$ Criação de programas mais amplos, a partir da avaliação/monitoramento das ações, por meio de instrumentos construídos por Universidade Pública, com a sistematização das práticas em desenvolvimento.

$\checkmark \mathrm{O}$ atendimento será realizado a todos que se aproximar do Consultório de Rua, independente de gênero, sexo e idade.

$\checkmark$ Possibilidade de abordagem pela via das DST/AIDS/Hepatites Virais, e não do uso de drogas. 
V - Quarto momento

Algumas considerações foram tecidas e compartilhadas por todo grupo:

$\checkmark$ Necessidade de assegurar a sustentabilidade das ações, tanto no que se refere à instabilidade de financiamento quanto à questões de ordem jurídicas durante o desenvolvimento das ações.

$\checkmark$ Aspectos legais que assegurem algumas ações da equipe de Consultório de Rua, como a distribuição de insumos (cachimbo para usuários de crack, protetores labiais, camisinhas).

$\checkmark$ Explorar mais o "perfil" dos profissionais para o trabalho sob a lógica da redução de danos e "fora dos muros".

$\checkmark$ Reuniões semanais para discussão e escuta da equipe.

$\checkmark$ Reunião semanal e anterior ao trabalho de campo (pré-campo), com mínimo de uma hora antes da saída para a rua, com o planejamento das atividades do dia.

$\checkmark$ Reuniões semanais e posteriores ao trabalho de campo (pós-campo), visando a descrição de como aconteceram as intervenções, o precisa ou não ser mudado. Tais reuniões podem acontecer em dia posterior ao dia das intervenções noturnas.

$\checkmark$ Construção de alguma forma de registro (nos moldes de um prontuário) durante ou após as intervenções, adequada ao contexto das intervenções.

$\checkmark$ Incorporação de alguém da comunidade, podendo ser capacitado como redutor de danos.

$\checkmark$ Selecionar para compor os profissionais dos CR, usuários dos CAPS AD que estejam num atendimento não intensivo.

$\checkmark$ Seguir as experiências exitosas da DST/AIDS/Hepatites Virais: usuários como redutores de danos, com discussão acerca da responsabilidade e compromissos.

$\checkmark$ O encaminhamento para CAPS AD ou qualquer outra instituição não pode ser o objetivo principal, podendo ocorrer no decorrer das ações. O Consultório de Rua deve funcionar como ponte.

$\checkmark$ Necessidade de estabelecimento de contato com associações, Ministério Público, Justiça, Segurança Pública e outros parceiros intersetoriais de programas de inclusão social e cultural, no sentido anunciar a existência e objetivos dos serviços e facilitar a integração.

$\checkmark$ Como seria uma estratégia de abordagem de redutores de danos para crianças?

$\checkmark$ Aspecto político das ações: a droga nos grupos de CR é uma questão de sustentabilidade social.

$\checkmark$ Mobilização de familiares de usuários, mesmo que sob a forma de visita domiciliar.

$\checkmark$ Sugestão de manter diálogo com a mídia, no sentido de desfazer a concepção do uso de drogas como doença.

$\checkmark$ Adoção de critérios diferenciados de uso de substâncias psicoativas.

$\checkmark$ Mobilização da rede de saúde que apresentarem resistência. 
VI - Quinto momento

Foi apresentada a proposta da Supervisão dos Consultórios de Rua e as normas gerais para seu funcionamento. A Universidade Federal da Bahia é a instituição responsável pela supervisão dos $\mathrm{CR}$, sob coordenação técnica do Prof. Tarcísio Mattos de Andrade. Os demais supervisores colaboradores foram escolhidos a posteriori.

Objetivos da supervisão

a. Supervisionar, monitorar e avaliar as ações

b. Realizar capacitação (acompanhamento do campo, supervisão clinica e atividade de docência)

c. Estimular e avaliar a articulação com a rede

d. Desenvolver estudo e pesquisa

e. Realizar evento que favoreça o diálogo e a troca de experiência (no final do período de 12 meses)

Sugestão: criação de um blog para trocar experiência dos municípios e supervisores.

VII - Sexto momento

Discutiu-se de forma mais aprofundada, sobre os componentes principais do Consultório de Rua.

A. Equipe volante

B. Veiculo amplo

C. Insumo (proposta em questão)

D. Rotina de atividade

1. A equipe tem papel fundamental, é o papel instrumento do PCR. Necessita de capacitação e aprimoramento constante.

2. Supervisão, capacitação a parti da demanda da pratica.

3. Integrantes da equipe-Saúde mental

4. Atenção Básica

5. Trabalhadores da educação, cultura, esporte, outros

E. Praticas e estratégias de Ação

1. Difundir área atuação

2. Estado do Território

3. Caracterização do publico alvo

4. Levantamento de especificidades locais

5. Entrada em campo

6. Ofertas de cuidado

7. Ação de cuidados básicos

8. Demandas clinicas e emergenciais

9. Imunização

10. Prevenção DST

11. Atividade de abordagem, orientação prevenção e assistência

12. Manejo de demandas para tratar em relação ao uso de SPAs

13. Elaboração de PTI

14. Diário de campo

15. Avaliação das ações reuniões de equipe e intersetoriais 
16. Supervisão local

17. Monitoramento do MS

18. Relatório bimestral, enviado on line para o MS, com o andamento dos projetos, contendo:

a. Identificação da área, clientela e demanda

b. Reunião realizada

c. Como se deu a entrada em campo

d. Outras ações realizadas

e. Dificuldades encontradas

f. Facilidades

g. Sugestões 
Anexo 2

Chamadas de Seleção de Projetos de Consultório de Rua

A primeira Chamada aconteceu em novembro de 2009, se inscreveram 32 projetos e selecionados 14. Na segunda chamada foram 50 projetos inscritos e selecionados 20.

\section{CHAMADA PARA SELEÇÃO DE PROJETOS DE CONSULTÓRIOS DE RUA E REDUÇÃO DE DANOS (PCR-II)}

Portaria no 1.059/GM de 04 de julho de 2005

\section{I- Introdução:}

1. O cenário epidemiológico atual do consumo de substâncias psicoativas, especialmente álcool, cocaína (crack, merla e pasta base) e inalantes, tem convocado diferentes setores do governo e da sociedade civil para a criação de estratégias e intervenções com vistas à prevenção, promoção da saúde, tratamento e redução de danos sociais e à saúde associados ao consumo prejudicial dessas substâncias. $\mathrm{O}$ Ministério da Saúde lançou, em junho de 2009, o Plano Emergencial de Ampliação do Acesso ao Tratamento e Prevenção em Álcool e Outras Drogas (PEAD), que tem como diretrizes gerais a) direito ao acesso ao tratamento, b) redução da lacuna assistencial, c) enfrentamento do estigma, d) qualificação das redes de saúde e seus trabalhadores, e) adoção da estratégia de redução de danos, f) ampliação e intensificação das ações intersetoriais, e g) reconhecimento dos determinantes sociais de vulnerabilidade, risco e padrões de consumo, e intervenção integrada sobre tais fatores (Portaria no 1.190, 04 de junho de 2009).

2. A ausência de demanda de ajuda e de acesso aos serviços da rede de saúde por parte da população usuária de drogas moradora de rua, em especial as crianças, adolescentes e jovens, levanta, há muito tempo, a necessidade de intervenções biopsicossociais efetivas, urgentes e integradas, in loco. As abordagens feitas no local de uso de álcool e outras drogas possibilitam ações preventivas, de promoção da saúde e de cuidados clínicos primários, além de aproximar essa população, quando necessário e de forma sistêmica e integrada, a outros serviços de tratamento para os problemas que envolvem o consumo de substâncias psicoativas. A característica mais importante desta intervenção é oferecer cuidados no próprio espaço da rua, preservando o respeito ao contexto sócio-cultural da população. Os projetos implantados têm demonstrado resultados satisfatórios, com produção de assistência primária, prevenção, melhora do acesso aos serviços de saúde e promoção de vida.

3. A Portaria GM 1059, de 04 de julho de 2005, foi instituída com o objetivo de apoiar os Estados, Municípios e Distrito Federal na ampliação da rede de serviços e 
ações de atenção integral, incluindo redução de danos, nas redes locais de saúde mental. Nesse sentido, com o objetivo de contribuir para a ampliação do acesso aos cuidados de saúde para pessoas que usam álcool e outras drogas no SUS, potencializar intervenções desenvolvidas em contexto de rua e articular diferentes redes de atenção a população usuária, especialmente crianças, adolescentes e jovens moradores de rua em situação de vulnerabilidade e risco de naturezas diversas, a Coordenação de Saúde Mental, Álcool e outras Drogas do Ministério da Saúde selecionará 20 Projetos de “Consultórios de Rua e Redução de Danos", que receberão, em 2010/2011, incentivo financeiro para fomentar ações realizadas nas ruas e ambientes de convívio da população-alvo, nos termos da Portaria GM 1059/2005.

4. Após aprovados, os projetos selecionados deverão ser executados em duas fases.

$\mathrm{Na}$ fase I, os projetos receberão o incentivo no valor de $\mathrm{R} \$ 50.000,00$ (cinqüenta mil reais). Após 06 meses, a partir da avaliação dos resultados das intervenções, poderão ser encaminhadas propostas de continuidade ao projeto - fase II -, seguindo-se novo repasse de recursos, com valor e duração iguais aos da fase I, nos termos da Portaria GM 1059/2005.

5. Poderão participar desta seleção (PCR II) Secretarias Municipais de Saúde de municípios com mais de $\mathbf{3 0 0 . 0 0 0}$ habitantes.

6. A experiência de Consultórios de Rua foi iniciada em Salvador, BA, no final dos anos 90, e consiste na disponibilização de recursos móveis para abordagem e acolhimento das situações de uso prejudicial de Álcool e outras Drogas nos locais onde vivem e/ou se encontram os usuários.

\section{Seus componentes principais são:}

a) uma equipe volante, devidamente identificada por crachá e/ou camiseta, constituída por profissionais da saúde mental, da atenção básica, técnicos de enfermagem e pelo menos um profissional da área de assistência social;

b) um veículo amplo, capaz de prover o deslocamento da equipe e armazenamento dos insumos durante as ações;

c) insumos para tratamento de situações clínicas comuns, preservativos, cartilhas e material instrucional, material para curativos, medicamentos de uso mais freqüente em tais situações;

d) rotina de atividade, contendo os protocolos clínicos aplicáveis, os fluxos de referência para continuidade da atenção quando for o caso, e as intervenções psicossociais e educativas, que levem em conta as especificidades socioculturais e epidemiológicas locais. 
II - Sobre os Projetos “Consultórios de Rua e Redução de Danos" (PCR):

1. Os Projetos "Consultórios de Rua e Redução de Danos" deverão:

A. Constituir-se como dispositivos públicos componentes da rede de atenção integral em saúde mental, oferecendo às pessoas com problemas decorrentes do uso de álcool e outras drogas ações de promoção, prevenção e cuidados primários no espaço da rua. B. Promover ações que enfrentem as diversas formas de vulnerabilidade e risco, especialmente em crianças, adolescentes e jovens.

C. Ter como eixos o respeito às diferenças, a promoção de direitos humanos e da inclusão social, o enfrentamento do estigma, as estratégia de redução de danos e a intersetorialidade.

D. Estar alinhados às diretrizes da Política para Atenção Integral a Pessoas que Usam Álcool e Outras Drogas, do Plano Emergencial de Ampliação do Acesso ao Tratamento e Prevenção em Álcool e outras Drogas, da Política Nacional de Saúde Mental, da Política Nacional de DST/AIDS, da Política de Humanização e da Política de Atenção Básica do Ministério da Saúde.

III - Das inscrições para o processo seletivo:

1. As inscrições para a Chamada para Seleção de Projetos de Consultórios de Rua e Redução de Danos (PCR-II) serão feitas através de formulário eletrônico, disponível no período de $\mathbf{2 9}$ de abril a 15 de maio de 2010, no sítio abaixo:

http://formsus.datasus.gov.br/site/formulario.php?id aplicacao=3964

2. O formulário eletrônico deverá ser preenchido pelo Coordenador de Saúde Mental do Município ou pelo Coordenador (a) do projeto proponente, devendo ser resultante de um processo coletivo de construção.

3. Para o preenchimento do formulário, é necessário ter disponível:

a) Dados de identificação do projeto (nome e local em que será desenvolvido);

b) Dados de identificação dos gestores municipais (Secretário Municipal de Saúde e Coordenação de Saúde Mental do Município)

c) Dados de identificação do(a) Coordenador(a) do Projeto

d) Arquivo eletrônico com projeto e plano de aplicação do incentivo

e) Informações sobre principais ações desenvolvidas ou previstas

4. Os proponentes deverão preencher o formulário eletrônico e as inscrições se darão exclusivamente por meio desse instrumento. 
5. Serão aceitos um ou mais projetos por município, porém cada projeto deve ter um serviço de saúde mental específico de referência (preferencialmente CAPSad); municípios com população entre hum milhão a 2,5 milhões de habitantes poderão inscrever até 03 (dois) projetos; municípios com população superior a 2,5 milhões de habitantes poderão inscrever até 04 (quatro) projetos, todos com áreas de abrangência específicas.

6. Serão aceitos projetos de municípios sem CAPSad, porém deverão ter outra modalidade de CAPS ou serviço de Saúde Mental de referência para o PCR.

7. Não é necessário o envio de material impresso para a Coordenação de Saúde Mental/MS, sendo todo o processo realizado por meio eletrônico.

8. A comprovação das informações prestadas, assim como outros documentos exigidos pela PT GM 1059/2005, serão solicitadas posteriormente, e apenas aos Projetos selecionados, sendo indispensáveis para a confirmação da seleção.

9. Orientações sobre os itens para elaboração do projeto estão contidas no Anexo A.

\section{IV - Dos critérios para a seleção dos serviços}

São critérios de prioridade para a seleção dos projetos:

1. Porte populacional: projetos municipais ou intermunicipais com mais de 300 mil habitantes.

2. Municípios do PEAD

3. Segmento populacional : propostas dirigidas a grupos de maior vulnerabilidade e risco (crianças, adolescentes e jovens)

4. Articulação com a Rede de Saúde Mental e da Atenção Básica, especialmente com as Equipes de Saúde da Família, CAPS e Hospitais Gerais.

5. Articulação com o Sistema Único de Assistência Social - SUAS, especialmente com os CRAS e CREAS.

6. Redução de Danos: contratação imprescindível de, no mínimo, 03 redutores de danos.

7. Intersetorialidade: articulação com outros setores do governo e da sociedade civil ação social, direitos humanos, educação, justiça, esporte e cultura.

\section{V - Do repasse dos incentivos}


1.0 incentivo (Fase I) será repassado em uma única parcela ao Fundo Municipal de Saúde, de acordo com a Portaria 1059/2005;

2.Serão aprovados 20 projetos com valor individual de $\mathrm{R} \$ 50.000,00$ (cinqüenta mil reais), na Fase I, e, a partir da avaliação dos resultados da intervenção, poderão ser encaminhadas propostas de continuidade do projeto - Fase II, com duração e valor idênticos à Fase I.

\section{VI - Da Consultoria Técnica e Acompanhamento dos Projetos Selecionados}

Os Consultórios de Rua são projetos-piloto de ampliação das ações territoriais de atenção integral em álcool e outras drogas (AOD). Por esta característica, os projetos selecionados contarão com Consultoria Técnica e Acompanhamento do Ministério da Saúde, através de 02 (duas) oficinas nacionais e de supervisão e consultoria no local de funcionamento de cada PCR, realizada com apoio de equipe de consultores de instituições colaboradoras. Uma Comissão de Acompanhamento do PCR-II será constituída, com a participação de consultores e dos coordenadores dos projetos selecionados.

\section{VI - Do Resultado da Seleção}

A listagem com os 20 Projetos selecionados estará disponível nos sítios www.saude.gov.br/saudemental e www.saude.gov.br, a partir do dia 20 de maio de 2010.

\section{VII - Da documentação a ser encaminhada pelos projetos selecionados:}

Os Projetos selecionados deverão enviar até o dia 25 de maio (data de postagem), ao Ministério da Saúde - Área Técnica de Saúde Mental/DAPES/SAS, com cópia para a Coordenação Estadual de Saúde Mental, a seguinte documentação, nos termos do Art 40 da Portaria GM 1059/2005:

a) ofício assinado pelo gestor solicitando o incentivo financeiro e identificando o projeto que será beneficiado;

b) projeto técnico (conforme estabelecido no item II e no Anexo A desta Chamada), assinado pelo responsável pela área de saúde mental do município;

c) relação dos agentes redutores de danos que estão vinculados ao serviço; acompanhado de dados de identificação.

d) termo de compromisso do gestor local assegurando a aplicação integral do incentivo financeiro no projeto ou no conjunto de projetos em até 3 (três) meses após seu recebimento;

e) proposta técnica de aplicação do recurso; 
Os documentos devem ser enviados para:

Ministério da Saúde

Coordenação Geral de Saúde Mental, Álcool e Outras Drogas

Esplanada dos Ministérios, Bloco G, 60 andar, sala 603

CEP: 70058-900

Brasília - DF.

O envio destes documentos é indispensável para o recebimento do incentivo.

Maiores informações:

Miriam Di Giovanni (miriam.giovanni@saude.gov.br)

Brasília, 29 de abril de 2010.

Coordenação Geral de Saúde Mental, Álcool e Outras Drogas

DAPES/SAS

Ministério da Saúde 


\section{ANEXO 3}

\section{PORTARIA No 1.190, DE 4 DE JUNHO DE 2009}

Institui o Plano Emergencial de Ampliação do Acesso ao Tratamento e Prevenção em Álcool e outras Drogas no Sistema Único de Saúde - SUS (PEAD 2009-2010) e define suas diretrizes gerais, ações e metas.

O MINISTRO DE ESTADO DA SAÚDE, no uso das atribuições que lhe conferem os incisos I e II do parágrafo único do art. 87 da Constituição, e

Considerando o cenário epidemiológico recente, que mostra a expansão no Brasil do consumo de algumas substâncias, especialmente álcool, cocaína (pasta-base, crack, merla) e inalantes, que se associa ao contexto de vulnerabilidade de crianças, adolescentes e jovens;

Considerando a lacuna assistencial nas políticas de saúde para a questão da prevenção e tratamento dos transtornos associados ao consumo do álcool e de outras drogas;

Considerando a necessidade de intensificar, ampliar e diversificar as ações orientadas para prevenção, promoção da saúde, tratamento e redução dos riscos e danos associados ao consumo prejudicial de substâncias psicoativas;

Considerando a necessidade de construção, sob a coordenação do campo da saúde pública, de respostas públicas intersetoriais eficazes, sensíveis à cultura e às peculiaridades da clínica de álcool e outras drogas;

Considerando a necessidade de fortalecimento e qualificação da rede de atenção à saúde mental existente;

Considerando a Lei $\mathrm{n}^{\circ}$ 10.216, de 6 de abril de 2001, que "dispõe sobre a proteção e os direitos das pessoas portadoras de transtornos mentais e redireciona o modelo assistencial em saúde mental";

Considerando a Lei $\mathrm{n}^{\circ}$ 8.069, de 13 de julho de 1990, que institui o Estatuto da Criança e do Adolescente e, em seus arts. $4^{\circ}$ e $11^{\circ}$, estabelece como absoluta prioridade, a efetivação dos direitos referentes à vida e à saúde por meio de políticas públicas que assegurem o acesso universal e igualitário às ações e serviços para a promoção, proteção e recuperação da saúde;

Considerando as diretrizes da Política do Ministério da Saúde para a Atenção Integral a Usuários de Álcool e outras Drogas;

Considerando as diretrizes e recomendações para Atenção Integral à Saúde de Adolescentes e Jovens;

Considerando as diretrizes da Política Nacional de Promoção da Saúde, no que diz respeito à morbimortalidade em decorrência do uso abusivo de álcool e outras drogas, às ações preventivas ao con-sumo de álcool e outras drogas previstas no Programa Saúde na Escola e à necessidade de abordagens preventivas e de promoção da saúde dirigidas às crianças desde a primeira infância; 
Considerando a Portaria n ${ }^{\circ}$ 2.197/GM, de 14 de outubro de 2004, que redefine e amplia a atenção integral para usuários de álcoole outras drogas, no âmbito do Sistema Único de Saúde - SUS;

Considerando a Portaria no 816/GM, de 30 de abril de 2002, que institui o Programa Nacional de Atenção Comunitária Integrada aUsuários de Álcool e outras Drogas;

Considerando a Portaria n $1.612 / G M$, de 9 de setembro de 2005, que aprova as Normas de Funcionamento e Credenciamento/Habilitação dos Serviços Hospitalares de Referência para a Atenção Integral aos Usuários de Álcool e outras Drogas;

Considerando a Política Nacional de Humanização (PNH), que atravessa as diferentes ações, serviços e instâncias gestoras do SUS;

Considerando as determinações da Portaria Interministerial MS/SEDH/SEPM n ${ }^{\circ} 1.426$, de 14 de julho de 2004 e da Portaria SAS/MS nº 647, de 11 de novembro de 2008, que dispõem sobre a atenção integral de saúde para adolescentes em cumprimento de medidas sócio-educativas;

Considerando a adesão do Brasil ao Programa "Mental Health Gap Action Program", da Organização Mundial da Saúde, de 2008, que prevê estratégias para a redução da lacuna assistencial entre a demanda e a oferta de serviços para atenção em saúde mental em todos os países do mundo, especialmente os países em desenvolvimento; e

Considerando a pactuação ocorrida na Reunião Ordinária da Comissão Intergestores Tripartite - CIT, realizada no dia 28 de maio de 2009, resolve:

Art. $1^{\text {o }}$ Instituir o Plano Emergencial de Ampliação do Aces-so ao Tratamento e Prevenção em Álcool e outras Drogas no SistemaÚnico de Saúde -SUS (PEAD 2009 2010), com as seguintes finalidades:

I - ampliar o acesso ao tratamento e à prevenção em álcoole outras drogas no Sistema Único de Saúde (SUS);

II -diversificar as ações orientadas para a prevenção, promoção da saúde, tratamento e redução dos riscos e danos associados ao consumo prejudicial de substâncias psicoativas; e

III - construir respostas intersetoriais efetivas, sensíveis ao ambiente cultural, aos direitos humanos e às peculiaridades da clínica do álcool e outras drogas, e capazes de enfrentar, de modo sustentável, a situação de vulnerabilidade e exclusão social dos usuários.

Art. $2^{\circ}$ São prioridades do PEAD:

I -Os 100 maiores municípios, com população superior a 250.000 habitantes, além de Palmas, por ser capital, e 7(sete) municípios de fronteira, listados todos no Anexo I desta Portaria, por apresentarem fragilidades na rede assistencial e/ou problemas de maior magnitude, do ponto de vista epidemiológico; e

II - O segmento populacional formado por crianças, adolescentes e jovens em situação de vulnerabilidade e risco.

Parágrafo único. As ações, já em curso e/ou planejadas, de expansão e qualificação da rede de saúde mental nos demais municípios, não sofrerão prejuízo em função da prioridade definida no caput. Caso sejam identificadas novas necessidades emergenciais, outros municípios poderão ser incorporados ao PEAD. 
Art. $3^{\circ}$ Estabelecer que as ações do PEAD (2009 -2010) devem orientar-se segundo as seguintes diretrizes gerais:

I - direito ao tratamento: todo usuário de álcool e outras drogas tem direito a um tratamento de qualidade, ofertado pela rede de serviços do SUS, e que considere os diversos aspectos envolvidos no seu processo de adoecimento;

II - redução da lacuna assistencial: ao SUS cabe a tarefa de garantir o acesso a ações e serviços de saúde mental, compatíveis com as demandas dos usuários de álcool e outras drogas;

III - respeito e promoção dos direitos humanos e da inclusão social: os usuários de álcool e outras drogas devem ser tratados com dignidade e respeito e a eles deve ser garantido o real acesso ao direito à saúde, ao bem-estar físico e mental, ao tratamento de qualidade, à moradia, à cultura, entre outros;

IV - enfrentamento do estigma: deve haver uma dimensão política de enfrentamento do estigma associada a toda e qualquer ação proposta para a população usuária de álcool e outras drogas, tendo em vista que o acesso ao cuidado tem importantes barreiras sociais, oriundas da compreensão ainda existente de que a estes cidadãos devem ser ofertadas somente políticas repressivas. $\mathrm{O}$ estigma se manifesta também pela desconfiança dos usuários em relação ao acolhimento e cuidado oferecidos pelo Estado;

V -garantia de acesso a um tratamento de eficácia comprovada: na discussão de modelos de atenção aos usuários de álcool e outras drogas é preciso incorporar as pesquisas e avaliações que vêm sendo feitas no país e no exterior, que apontam as melhores estratégias, eficazes e custo-efetivas, de cuidado para essa população;

VI -reconhecimento dos determinantes sociais de vulnerabilidade, risco e dos padrões de consumo: as políticas públicas voltadas para os usuários de álcool e outras drogas devem levar em conta a estreita ligação entre a dinâmica social e os processos de adoecimento;

VII - garantia do cuidado em rede, no território, e de atenção de base comunitária: o cuidado integral aos usuários de álcool outras drogas deve ser garantido em uma rede diversificada de ações e serviços de saúde mental, de base comunitária e territorial;

VIII - priorização de ações para crianças, adolescentes jovens em situações de vulnerabilidade: há uma tendência de uso de álcool e outras drogas cada vez mais cedo nessa população, além das altas prevalências de uso de álcool e drogas entre jovens. Esta situação apresenta-se mais grave quando se considera também o impacto das consequências danosas do álcool e do crack, por exemplo, na vida afetiva, familiar e social, além dos prejuízos à saúde nessa população;

IX - enfoque intersetorial: o cuidado à saúde mental da população infanto-juvenil tem sempre caráter multidisciplinar e intersetorial. As ações de atenção integral à crianças e adolescentes não se desenvolvem somente no campo das ações clínicas, mas se relacionam com as questões da família, da comunidade, da escola, da moradia, do trabalho, da cultura, além dos grandes problemas sociais do mundo contemporâneo como o tráfico de drogas e a violência;

$\mathrm{X}$ - qualificação das redes de saúde: devem ser ampliadas as ofertas de capacitação e fortalecidos os processos de formação permanente e supervisão para profissionais que lidam com essa população, de acordo com as demandas identificadas; e 
XI - adoção da estratégia de redução de danos: este deve ser um norte ético de todo e qualquer serviço do SUS, que deve reduzir os danos decorrentes do consumo de álcool e outras drogas, especialmente relacionados à saúde, mas não exclusivamente. Trata-se de uma diretriz que toma como base as condições e possibilidades do usuário do SUS, em vez de partir do que os serviços oferecem.

Art. $4^{\text {o }}$ Definir os seguintes eixos de intervenções para as linhas de ação do PEAD (2009-2010):

I - EIXO 1 - Ampliação do acesso ao tratamento: expansão da rede de Centros de Atenção Psicossocial (CAPS); ampliação dos leitos de atenção integral em saúde mental e do atendimento pela Rede de Urgência e Emergência; expansão das ações de saúde mental na atenção básica; articulação efetiva da rede de saúde com a rede de suporte social:

a) expansão dos Centros de Atenção Psicossocial Álcool e outras Drogas (CAPSad), Centros de Atenção Psicossocial Infanto-Juvenil (CAPSi) e Centros de Atenção Psicossocial 24 horas (CAPS III), de modo a assegurar cobertura ambulatorial plena nos municípios prioritários;

b) implantação de leitos de atenção integral em saúde mental em hospitais gerais;

c) estímulo ao fortalecimento do componente de saúde mental/álcool e outras drogas nas equipes de saúde da família e nos Núcleos de Apoio à Saúde da Família (NASF), através da incorporação de profissional capacitado em álcool/drogas às novas equipes dos NASF nos Municípios prioritários;

d) construção de mecanismos para implantação do acolhimento com classificação de risco a situações de álcool e outras drogas na Rede de Urgência e Emergência, com garantia de continuidade do cuidado e fomento à ampliação do acesso para atendimento pela Rede de Urgência e Emergência - SAMU 192, UPA 24h e QualiSUS -a estas situações clínicas;

e) implantação/piloto de casas de passagem/moradias assistidas e outras experiências de acolhimento transitório;

f) fortalecimento e expansão de experiência de intervenção comunitária, como consultórios de rua, ações no território, atenção domiciliar e outros (articuladas à atenção básica e visando à inclusão social);

g) articulação eficaz da rede de saúde mental do SUS com a rede de suporte social intersetorial, composta por entidades governamentais e não-governamentais;

II -EIXO 2 - Qualificação da Atenção -Formação, avaliação, monitoramento e produção de conhecimento: qualificação da rede de cuidados, com investimento na formação, avaliação, monitoramento e produção de conhecimento:

a) realização de cursos de Especialização e atualização em saúde mental, com ênfase em álcool e drogas, para profissionais da atenção básica e Centros de Atenção Psicossocial CAPS (incluindo a estratégia de Telessaúde e ensino a distância);

b) criação do Observatório Nacional sobre Álcool, Drogas e Saúde Pública; c) implantação da Rede de Pesquisa em Saúde Mental; d) lançamento de publicações sobre álcool e outras drogas dirigidas a públicos diversificados; e

e) desenvolvimento de ações contínuas de monitoramento e avaliação das ações de saúde mental, com ênfase nos CAPS e atenção básica. 
III - EIXO 3 -Articulação intra e intersetorial, com a sociedade civil e participação social: apoio à articulação entre as políticas da Saúde, Desenvolvimento Social, Educação, Esporte, Justiça, Trabalho, Direitos Humanos, Cultura e outras políticas sociais. Apoio a ações com a participação da sociedade civil, em projetos comunitários que se articulem às redes de saúde mental:

a) implantação de ações culturais articuladas ao campo da saúde mental (Programa Mais Cultura/Ministério da Cultura);

b) apoio a iniciativas de Geração de Renda e Inclusão Social pelo trabalho, para pessoas com transtornos mentais relacionadas ao uso de álcool e outras drogas;

c) criação de Comitê Interministerial para integração de políticas federais para ações intersetoriais de prevenção e tratamento voltadas para usuários de álcool e drogas;

d) incentivo e qualificação das ações de redução de danos na rede de atenção em saúde mental, em articulação com a rede ampliada de saúde e proteção social;

e) implantação de Centros de Convivência (Pontos de Acolhimento e Integração Social) para usuários de álcool e outras drogas, em articulação com as políticas de assistência social e direitos humanos; e

f) fomento à criação de fóruns intersetoriais voltados para crianças e adolescentes em situação de vulnerabilidade;

g) ampliação da rede de suporte social (instituições sociais e de acolhimento, casas de passagem, grupos de ajuda mútua e outras); e

h) ampliação de ações em articulação com o Programa Nacional de Segurança Pública com Cidadania - PRONASCI.

IV -EIXO 4 -Promoção da saúde e dos direitos, inclusão social, enfrentamento do estigma: apoio a estratégias e ações para a sensibilização de gestores, profissionais e população em geral sobre os direitos das pessoas que usam álcool e outras drogas e a experiências comunitárias e ações culturais que trabalham com o estigma e com a inclusão social:

a) promoção de educação para prevenção do uso de álcool e outras drogas para alunos do ensino técnico, médio e fundamental;

b) sensibilização de gestores públicos da rede de atenção à saúde mental para os direitos dos usuários de álcool e outras drogas, especialmente crianças e adolescentes, e para o estigma como barreira para o acesso aos serviços;

c) articulação de ações com os Núcleos de Prevenção de Violências e Promoção da Saúde já implantados nos Municípios prioritários do PEAD;

d) desenvolvimento prioritário de ações conjuntas previstas no componente da redução da morbimortalidade em decorrência do uso abusivo de álcool e outras drogas da Política Nacional de Promoção da Saúde;

e) fortalecimento da articulação com as ações do Programa Saúde na Escola (Departamento de Ações Programáticas Estratégicas -DAPES/Departamento de Atenção Básica - DAB, da Secretaria de Atenção à Saúde/Ministério da Saúde e Ministério da Educação MEC) e Programa Saúde e Prevenção nas Escolas (Secretaria de Atenção à Saúde/Secretaria de Vigilância em Saúde -Ministério da Saúde e Ministério da Educação - MEC); e 
f) desenvolvimento de ações de promoção e prevenção em saúde mental na primeira infância.

$\S 1^{\circ}$ A definição das prioridades para a implantação dos CAPS e outras ações de ampliação do acesso, nos Municípios listados no Anexo I, levará em conta a combinação dos seguintes critérios:

I - Critério 1: Parâmetro populacional;

II - Critério 2: Cobertura de CAPS/100.000 habitantes;

III - Critério 3: Cobertura existente de leitos de atenção integral em saúde mental; IV -

Critério 4: Garantia da equidade regional; V -Critério 5: Cobertura de equipes de saúde da família; e

VI - Critério 6: Existência de Serviço de Atendimento Móvel de Urgência -SAMU 192 ou sistema de regulação urgência/emergência.

$\S 2^{\circ}$ Os objetivos, ações e metas do Plano de Ação do PEAD estão descritas no Anexo II desta Portaria.

Art. $5^{\circ}$ Definir que o componente hospitalar do PEAD deverá atender às diretrizes e especificações da Portaria $\mathrm{n}^{\circ} 1.612 / \mathrm{GM}$, de 9 de setembro de 2005, que aprova as Normas de Funcionamento e Credenciamento/Habilitação dos Serviços Hospitalares de Referência para a Atenção Integral aos Usuários de Álcool e outras Drogas (SHRad) e das recomendações propostas pelo Grupo de Trabalho sobre Saúde Mental em Hospitais Gerais, instituído pela Portaria $\mathrm{n}^{\circ} 1.899 / \mathrm{GM}$, de 11 de setembro de 2008.

Parágrafo único. O componente hospitalar do PEAD deve conter mecanismos formalmente definidos de referência e contrareferência, que incluam as redes locais ou regionais de urgência/emergência, de atenção psicossocial e de proteção social.

Art. $6^{\circ}$ Caberá ao Ministério da Saúde:

I - a gestão do PEAD no âmbito federal;

II - a articulação e integração dos programas do governo federal em torno do tema do acesso ao tratamento do uso/abuso deálcool e outras drogas e da violência;

III - prestar assessoria técnica aos Estados e aos Municípios no processo de discussão e implantação das ações do PEAD;

IV - apoiar técnica e financeiramente, no âmbito de sua competência e conforme pactuações estabelecidas, a ampliação dos serviços dos níveis hospitalar, ambulatorial e de atenção básica integrantes do PEAD;

$\mathrm{V}$ - monitorar, acompanhar e avaliar as ações desenvolvidas; e

VI - priorizar o cadastramento de unidades de saúde municipais que dependam de habilitação específica do Ministério da Saúde.

Art. $7^{\circ}$ Caberá às Secretarias de Estado da Saúde:

I - articular e integrar as ações do PEAD no âmbito estadual;

II - coordenar os mecanismos locorregionais de referência e contra-referência do componente hospitalar e da rede de urgência/ emergência;

III - apoiar técnica e financeiramente, no âmbito de sua competência e conforme pactuações estabelecidas, a ampliação dos serviços dos níveis hospitalar, ambulatorial e de atenção básica integrantes do PEAD;

IV - monitorar, acompanhar e avaliar, em sua esfera de atuação, as ações desenvolvidas; 
V - articular com os Municípios, listados no Anexo I, o desenvolvimento das ações previstas no PEAD 2009-2010.

Art. $8^{\circ}$ Compete às Secretarias Municipais de Saúde:

I - coordenar e executar as ações do PEAD no âmbito municipal;

II - construir mecanismos de articulação intermunicipal e locorregional;

III - apoiar técnica e financeiramente, no âmbito de sua competência e conforme pactuações estabelecidas, a ampliação dos serviços dos níveis hospitalar, ambulatorial e de atenção básica integrantes do PEAD;

IV - contribuir para a ampliação da oferta de serviços da rede integrante do PEAD, no âmbito de sua competência e conforme pactuações estabelecidas; e

V - monitorar, acompanhar e avaliar, em sua esfera de atuação, as ações desenvolvidas; VI - identificar, na rede de saúde mental municipal, a necessidade de expansão das intervenções de saúde e intersetoriais direcionadasàs pessoas que com transtornos associados ao consumo deálcool e outras drogas, previstas no PEAD 2009-2010.

Art. $9^{\circ}$ Instituir o Comitê de Acompanhamento e Avaliação do PEAD, coordenado pelo Ministério da Saúde/Secretaria de Atenção à Saúde/Departamento de Ações Programáticas Estratégicas/Área Técnica de Saúde Mental, e integrado pelas seguintes instâncias e instituições:

I - Ministério da Saúde;

a) Secretaria de Atenção à Saúde - SAS

1. Departamento de Ações Programáticas Estratégicas - DAPES:

- Área Técnica de Saúde Mental;

- Área Técnica de Saúde do Adolescente e do Jovem;

2. Departamento de Atenção Básica - DAB.

3. Departamento de Regulação, Avaliação e Controle de Sistemas - DRAC.

4. Departamento de Atenção Especializada - DAE.

b) Secretaria-Executiva - SE

c) Secretaria de Vigilância em Saúde - SVS

1. Departamento de Análise e Informação de Saúde - DASIS

2. Programa Nacional de DST-Aids

d) Secretaria de Gestão do Trabalho e da Educação na Saúde - SGTES

II - Conselho Nacional dos Secretários de Saúde - CONASS;

III - Conselho Nacional de Secretários Municipais de Saúde - CONASEMS; e

IV - Ministério do Desenvolvimento Social e Combate à Fome - MDS.

Parágrafo único. O Comitê de que trata este artigo contará com o apoio de um Grupo Consultivo Intersetorial para subsidiar a implementação do PEAD de acordo com as parcerias previstas.

Art. 10. Os recursos financeiros para execução das ações previstas nos Eixos 1 e 2, constantes do Anexo II a esta Portaria, deverão onerar as seguintes Funcionais Programáticas/Programas de Trabalho:

I - 10.302.1220.8585 - Atenção à Saúde da População para Procedimentos de Média e Alta Complexidade;

II - 10.302.1220.20B0 - Atenção Especializada em Saúde Mental;

III - 10.301.1312.6233 - Implementação de Políticas de Atenção à Saúde Mental; 
IV - 10.243.1312.6177 - Implementação de Políticas de Atenção à Saúde do

Adolescente e Jovem;

V - 10.301.1312.8762 - Implementação de Ações e Serviçosàs Populações em

Localidades Estratégicas e Vulneráveis de Agravo;

V - 10.128.1436.8612.0001 - Formação de Profissionais Técnicos de Saúde e

Fortalecimento das Escolas Técnicas/Centros de Formadores do SUS; e

VI - 10.364.1436.8628 - Apoio ao Desenvolvimento da Graduação, Pós Graduação Stricto e Latu Sensu, em Áreas Estratégicas para o SUS, relativas à Política Nacional de Educação Permanente em Saúde, prevista na Portaria no- 2.813/GM, de 20 de novembro de 2008 e Portaria n. 1996/GM, de 20 de agosto de 2007.

Parágrafo único. As programações orçamentárias por meio das quais serão executadas as ações intersetoriais relativas aos Eixos 3 e 4, previstos no Anexo II a esta Portaria, serão objeto de atos normativos específicos.

Art. 11. Esta Portaria entra em vigor na data de sua publicação, com efeitos financeiros a partir de julho de 2009

\section{.JOSÉ GOMES TEMPORÃO}

\section{ANEXO I}

\begin{tabular}{|c|c|c|}
\hline $\begin{array}{l}\text { Art. } 10 \mathrm{O} \\
\text { constante } \\
\text { Programá }\end{array}$ & $\begin{array}{l}\text { s para execução das açõe } \\
\text { Portaria, deverão onerar } \\
\text { Tr a b a } 1 \text { h o: }\end{array}$ & $\begin{array}{l}\text { evistas nos Eixos } 1 \text { e } 2 \text {, } \\
\text { guintes Funcionais }\end{array}$ \\
\hline Municípi & is ações do PEAD & \\
\hline U.F. & MUNICÍPIO & POPULAÇÃO \\
\hline SP & São Paulo & 10.990 .249 \\
\hline RJ & Rio de Janeiro & 6.161 .047 \\
\hline BA & Salvador & 2.948 .733 \\
\hline $\mathrm{DF}$ & Brasília & 2.557 .158 \\
\hline $\mathrm{CE}$ & Fortaleza & 2.473 .614 \\
\hline MG & Belo Horizonte & 2.434 .642 \\
\hline PR & Curitiba & 1.828 .092 \\
\hline AM & Manaus & 1.709 .010 \\
\hline $\mathrm{PE}$ & Recife & 1.549 .980 \\
\hline $\mathrm{RS}$ & Porto Alegre & 1.430 .220 \\
\hline $\mathrm{PA}$ & Belém & 1.424 .124 \\
\hline SP & Guarulhos & 1.279 .202 \\
\hline $\mathrm{GO}$ & Goiânia & 1.265 .394 \\
\hline SP & Campinas & 1.056 .644 \\
\hline MA & São Luís & 986.826 \\
\hline RJ & São Gonçalo & 982.832 \\
\hline $\mathrm{AL}$ & Maceió & 924.143 \\
\hline RJ & Duque de Caxias & 864.392 \\
\hline RJ & Nova Iguaçu & 855.500 \\
\hline SP & São Bernardo do Campo & 801.580 \\
\hline $\mathrm{RN}$ & Natal & 798.065 \\
\hline PI & Teresin a & 793.915 \\
\hline
\end{tabular}




\begin{tabular}{|c|c|c|}
\hline MS & Campo Grande & 747.189 \\
\hline SP & Osasco & 713.066 \\
\hline PB & João Pessoa & 693.082 \\
\hline$\overline{\mathrm{PE}}$ & Jaboatão dos Guararapes & 678.346 \\
\hline SP & Santo André & 671.696 \\
\hline MG & Uberlândia & 622.441 \\
\hline$\overline{M G}$ & Contagem & 617.749 \\
\hline SP & São José dos Campos & 609.229 \\
\hline $\mathrm{BA}$ & Feira de Santana & 584.497 \\
\hline SP & Sorocaba & 576.312 \\
\hline SP & Ribeirão Preto & 558.136 \\
\hline MT & Cuiabá & 544.737 \\
\hline SE & Aracaju & 536.785 \\
\hline$\overline{M G}$ & Juiz de Fora & 520.612 \\
\hline PR & Londrina & 505.184 \\
\hline$\overline{\mathrm{RJ}}$ & Belford Roxo & 495.694 \\
\hline $\mathrm{PA}$ & Ananindeua & 495.480 \\
\hline $\mathrm{GO}$ & Aparecida de Goiânia & 494.919 \\
\hline $\mathrm{SC}$ & Joinville & 492.101 \\
\hline RJ & Niterói & 477.912 \\
\hline RJ & São João de Meriti & 468.309 \\
\hline $\mathrm{RJ}$ & Campos dos Goytacazes & 431.839 \\
\hline MG & Betim & 429.507 \\
\hline SP & Santos & 417.518 \\
\hline SP & São José do Rio Preto & 414.272 \\
\hline SP & Mauá & 412.753 \\
\hline ES & Vila Velha & 407.579 \\
\hline$\overline{R S}$ & Caxias do Sul & 405.858 \\
\hline $\mathrm{SC}$ & Florianópolis & 402.346 \\
\hline$\overline{E S}$ & Serra & 397.226 \\
\hline$\overline{\mathrm{PE}}$ & Olinda & 394.850 \\
\hline SP & Diadema & 394.266 \\
\hline SP & Carapicuíba & 388.532 \\
\hline $\mathrm{PB}$ & Campina Grande & 381.422 \\
\hline RO & Porto Velho & 379.186 \\
\hline SP & Mogi das Cruzes & 371.372 \\
\hline SP & Piracicaba & 365.440 \\
\hline$\overline{E S}$ & Cariacica & 362.277 \\
\hline$\overline{\mathrm{AP}}$ & Macapá & 359.020 \\
\hline$\overline{M G}$ & Montes Claros & 358.271 \\
\hline SP & Bauru & 355.675 \\
\hline SP & Itaquaquecetuba & 351.493 \\
\hline SP & Jundiaí & 347.738 \\
\hline RS & Pelotas & 343.167 \\
\hline $\mathrm{MG}$ & Ribeirão das Neves & 340.033 \\
\hline$\overline{P R}$ & Maringá & 331.412 \\
\hline GO & Anápolis & 331.329 \\
\hline $\mathrm{RS}$ & Canoas & 329.903 \\
\hline SP & São Vicente & 328.522 \\
\hline SP & Franca & 327.176 \\
\hline $\mathrm{CE}$ & Caucaia & 326.811 \\
\hline
\end{tabular}




\begin{tabular}{||l|l|l||}
\hline PR & Foz do Iguaçu & 319.189 \\
\hline ES & Vitória & 317.817 \\
\hline PE & Paulista & 314.302 \\
\hline BA & Vitória da Conquista & 313.898 \\
\hline RJ & Petrópolis & 312.766 \\
\hline PR & Ponta Grossa & 311.106 \\
\hline SP & Guarujá & 304.274 \\
\hline AC & Rio Branco & 301.398 \\
\hline SC & Blumenau & 296.151 \\
\hline PE & Caruaru & 294.558 \\
\hline MG & Uberaba & 292.377 \\
\hline PR & Cascavel & 291.747 \\
\hline SP & Suzano & 279.394 \\
\hline SP & Limeira & 278.776 \\
\hline PE & Petrolina & 276.174 \\
\hline PA & Santarém & 275.571 \\
\hline PR & São José dos Pinhais & 272.530 \\
\hline SP & Taubaté & 270.918 \\
\hline RS & Santa Maria & 266.822 \\
\hline RS & Gravatá́ & 266.230 \\
\hline SP & Barueri & 264.619 \\
\hline MG & Governador Valadares & 261.981 \\
\hline RR & Boa Vista & 260.930 \\
\hline RJ & Volta Redonda & 259.811 \\
\hline RS & Viamão & 257.844 \\
\hline RS & Novo Hamburgo & 255.945 \\
\hline CE & Juazeiro do Norte & 246.515 \\
\hline TO & Palmas & 184.018 \\
\hline RS & Uruguaiana & 127.138 \\
\hline MS & Corumbá & 99.196 \\
\hline RS & Santana do Livramento & 84.779 \\
\hline MS & Ponta Porã & 74.601 \\
\hline AM & Tabatinga & 47.501 \\
\hline AM & São Gabriel da Cachoeira & 40.806 \\
\hline RO & Guajará-Mirim & 40.541 \\
\hline & & \\
\hline & & \\
\hline
\end{tabular}

\section{ANEXO II}

Plano de Ação do Plano Emergencial de Ampliação do Acesso ao Tratamento e Prevenção em Álcool e outras Drogas no Sistema Único de Saúde

\begin{tabular}{|l|l|}
\hline EIXO 1 & $\begin{array}{l}\text { AMPLIAÇÃO DO ACESSO AO TRATAMENTO EM SAÚDE } \\
\text { MENTAL }\end{array}$ \\
\hline Objetivo 1.1 & $\begin{array}{l}\text { Assegurar cobertura ambulatorial plena nos municípios prioritários, } \\
\text { através da implantação de } 92 \text { novos Centros de Atenção Psicossocial } \\
\text { (CAPS AD, CAPS-i e CAPS III). }\end{array}$ \\
\hline Objetivo 1.2 & \begin{tabular}{l} 
Implantar, nos municípios prioritários, 2.325 novos leitos de atenção \\
\hline
\end{tabular} \\
\hline
\end{tabular}




\begin{tabular}{|l|l|}
\hline & $\begin{array}{l}\text { integral em saúde mental especializados em atendimento de transtornos } \\
\text { de álcool/drogas, em hospitais gerais, nos termos da Portaria no } 1.612 / \mathrm{GM}, \text { de 09 de } \\
\text { setembro de 2005. }\end{array}$ \\
\hline Objetivo 1.3 & $\begin{array}{l}\text { Implantar acolhimento com classificação de risco a situações de álcool e outras drogas } \\
\text { na Rede de Urgência e Emergência, com garantia de continuidade do cuidado }\end{array}$ \\
\hline Objetivo 1.4 & $\begin{array}{l}\text { Estimular a contratação de pelo menos 1 profissional de saúde mental } \\
\text { nas equipes de Núcleos de Atenção à Saúde da Família (NASF) } \\
\text { a serem implantadas nos } 100 \text { maiores municípios do País e Capitais. }\end{array}$ \\
\hline Objetivo 1.5 & $\begin{array}{l}\text { Fomentar estratégias de implantação de projetos-piloto de casas de passagem/moradias } \\
\text { assistidas ou outras experiências de acolhimento transitório, em todos os municípios } \\
\text { com mais de 500.000 habitantes. }\end{array}$ \\
\hline
\end{tabular}

\begin{tabular}{|c|c|c|}
\hline \multicolumn{2}{|l|}{ EIXO 2} & $\begin{array}{l}\text { QUALIFICAÇÃO DA ATENÇÃO: FORMAÇÃO, SUPERVISÃO E } \\
\text { PRODUÇÃO DE INFORMAÇÃO E CONHECIMENTO }\end{array}$ \\
\hline \multicolumn{2}{|c|}{ Objetivo 2.1} & $\begin{array}{l}\text { Realizar } 15 \text { Cursos de Especialização regionais e } 65 \text { cursos de atualização em saúde } \\
\text { mental, com ênfase em álcool e drogas, abrangendo profissionais de saúde dos } 100 \\
\text { Municípios do país previstos no Anexo I, além de programas intensivos de ensino a } \\
\text { distância (Telessaúde e Supera III/SENAD). }\end{array}$ \\
\hline \multicolumn{2}{|c|}{ Objetivo 2.2} & Implantar Observatório Nacional sobre Álcool, Drogas e Saúde Pública. \\
\hline \multicolumn{2}{|c|}{ Objetivo 2.3} & $\begin{array}{l}\text { Qualificar e fortalecer os sistemas de informação/inquéritos que se } \\
\text { relacionam ao consumo de álcool e drogas. }\end{array}$ \\
\hline \multicolumn{2}{|c|}{ Objetivo 2.4} & $\begin{array}{l}\text { Ampliar a supervisão clínico-institucional junto aos CAPSad, CAPSi e CAPS III } \\
\text { cadastrados no SUS nos Municípios prioritários. }\end{array}$ \\
\hline \multicolumn{2}{|c|}{ Objetivo 2.5} & $\begin{array}{l}\text { Realizar levantamento preliminar para estimar a demanda potencial para tratamento } \\
\text { de crack nos } 100 \text { maiores Municípios brasileiros. }\end{array}$ \\
\hline \multicolumn{2}{|c|}{ Objetivo 2.6} & Implantar Rede de Pesquis \\
\hline \multicolumn{2}{|c|}{ Objetivo 2.7} & $\begin{array}{l}\text { Lançar publicação sobre álcool e outras drogas dirigidas aos profissionais da rede de } \\
\text { atenção à saúde mental e às redes intersetoriais (justiça, assistência social, cultura, } \\
\text { trabalho e outras) e publicação dirigida aos alunos da rede regular de ensino }\end{array}$ \\
\hline \multicolumn{3}{|c|}{$\begin{array}{cl}\text { EIXO } 3 & \text { ARTICULAÇÃO INTRA E INTERSETORIAL, SOCIEDADE CIVIL E PARTICIPAÇÃO } \\
& \text { SOCIAL }\end{array}$} \\
\hline $\begin{array}{l}\text { Objetivo } \\
3.1\end{array}$ & \multicolumn{2}{|r|}{$\begin{array}{l}\text { Publicar edital conjunto do Ministério da Saúde e Ministério da Cultura para implantação de } \\
\text { ações culturais articuladas às redes de saúde e saúde mental (Programa Mais Cultura) em } \\
2009 \text { e } 2010 .\end{array}$} \\
\hline $\begin{array}{l}\text { Objetivo } \\
3.2\end{array}$ & \multicolumn{2}{|r|}{$\begin{array}{l}\text { Publicar edital conjunto do Ministério da Saúde com Ministério do Trabalho e Emprego } \\
\text { (MTE) para apoio a } 100 \text { iniciativas de Geração de Renda. }\end{array}$} \\
\hline Objetivo & \multicolumn{2}{|r|}{ Fortalecer as ações educativas e de promoção da saúde relacionadas à associação do } \\
\hline
\end{tabular}


3.3 consumo de álcool e situações de violência, em parceria com Estados e Municípios.

Objetivo Consolidar as ações de prevenção de acidentes de trânsito relacionados com o consumo de 3.4 álcool - Estratégia conjunta com MS, MJ e Ministério das Cidades.

Objetivo Criar Comitê Interministerial para integração de políticas federais para ações intersetoriais 3.5 voltadas para o tratamento e prevenção ao consumo de álcool e outras drogas.

Objetivo Publicar e divulgar os projetos selecionados por meio do Edital para qualificação das ações 3.6 de redução de danos na rede de atenção em saúde mental (lançado em abril/09).

Objetivo Implantar 15 Pontos de Acolhimento e Integração Social (Centros de Convivência), em 3.7 articulação com Ministérios do Desenvolvimento Social e Combate à Fome (MDS) e Cultura (MINC) e Secretaria Especial de Direitos Humanos (SEDH), em municípios com populaçãosuperior a 500.000 habitantes.

Objetivo

3.8 Fomentar a criação de fóruns intersetoriais voltados para crianças e adolescentes em situação de vulnerabilidade com participação de operadores de justiça e defesa dos direitos humanos.

Objetivo Fomentar ações de prevenção do consumo de álcool e outras drogas e HIV/AIDS para 3.9 população de rua.

Objetivo Ampliar ações compartilhadas entre a rede de atenção básica e saúde mental, com os 3.10 Núcleos de Prevenção de Violências e Promoção da Saúde.

Objetivo Realizar Seminário Nacional sobre Atenção em Saúde Mental aos Adolescentes Privados de 3.11 Liberdade para divulgação e debate dos dados do Levantamento Nacional realizado sobre o tema (Brasília, agosto/09).

Objetivo

3.12 Realizar oficina nacional de articulação com comunidades terapêuticas e ONGs (Brasília, outubro/09).

3.13 Criar critérios para regulação das vagas para internação em comunidades terapêuticas, quando necessárias, no contexto locorregional.

\begin{tabular}{|l|l|}
\hline Objetivo 3.14 & Inserir o canal Disque Jovem no Disque Saúde. \\
\hline Objetivo 3.15 & Estimular e fortalecer a criação de grupos de protagonismo juvenil. \\
\hline Objetivo 3.16 & $\begin{array}{l}\text { Ampliar ações em articulação com o PRONASCI (Ministério da Justiça), } \\
\text { especialmente com o projeto "Drogas e Violência: respostas integradas" } \\
\text { (Ministério da Justiça/Gabinete de Segurança Institucional). }\end{array}$ \\
\hline Objetivo 3.17 & $\begin{array}{l}\text { Articular o PEAD com o Programa Jovem Atleta (Ministério dos Esportes), } \\
\text { Jovem Trabalhador (MTE), Inclusão Digital (MCT) e Pro-grama de Proteção a }\end{array}$ \\
\hline
\end{tabular}




\begin{tabular}{|l|l|}
\hline & $\begin{array}{l}\text { Crianças e Adolescentes Ameaçados de Morte (PPCAAM/SEDH) e } \\
\text { CRAS/CREAS (MDS). }\end{array}$ \\
\hline Objtetivo 3.18 & $\begin{array}{l}\text { Fomentar e apoiar, através de Edital, estratégias intersetoriais ativas de ações } \\
\text { extra-muros, que promovam no território alternativas de convivência, } \\
\text { sociabilidade e vínculos, às pessoas em situação de rua com transtornos mentais } \\
\text { e/ou associados ao consumo de álcool/drogas (30 projetos). }\end{array}$ \\
\hline
\end{tabular}

\begin{tabular}{|l|l|}
\hline EIXO 4 & $\begin{array}{l}\text { PROMOÇÃO DA SAÚDE, DOS DIREITOS E ENFRENTAMENTO AO } \\
\text { ESTIGMA }\end{array}$ \\
\hline Objetivo 4.1 & $\begin{array}{l}\text { Promover educação para prevenção do uso de álcool e outras drogas para alunos } \\
\text { do ensino técnico, médio e fundamental, em consonância com ações previstas } \\
\text { no Programa de Saúde nas Escolas e no Saúde e Prevenção nas Escolas } \\
\text { (Ministérios da Saúde e Educação). }\end{array}$ \\
\hline Objetivo 4.2 & $\begin{array}{l}\text { Articular ações desenvolvidas pelo Ministério da Saúde e Secretaria Especial de } \\
\text { Direitos Humanos para atenção integral em unidades de medida sócio- } \\
\text { educativa. }\end{array}$ \\
\hline Objetivo 4.3 & $\begin{array}{l}\text { Incluir nas ações de Educação Popular em Saúde que contribuam para ampliar o } \\
\text { conhecimento da população sobre o uso de álcool e outras drogas, com vistas a } \\
\text { combater a exclusão social, o preconceito e o estigma em relação às pessoas que } \\
\text { fazem uso de álcool e outras drogas. }\end{array}$ \\
\hline Objetivo 4.4 & $\begin{array}{l}\text { Incorporar, nas ações de humanização dirigidas aos profissionais de saúde, a } \\
\text { redução do estigma no acolhimento e tratamento dos usuários de álcool e outras } \\
\text { drogas e na continuidade do cuidado dos usuários na rede. }\end{array}$ \\
\hline Objetivo 4.5 & \begin{tabular}{l} 
Realizar de Seminário sobre Drogas e Mídia (Brasília, setembro/09). \\
\hline
\end{tabular}
\end{tabular}


ANEXO 4

\section{DECRETO N 7.179, DE 20 DE MAIO DE 2010}

Institui o Plano Integrado de Enfrentamento ao Crack e outras Drogas, cria o seu Comitê Gestor, e dá outras providências.

O PRESIDENTE DA REPÚBLICA, no uso da atribuição que lhe confere o art. 84, inciso VI, alínea "a", da Constituição,

\section{DECRETA:}

Art. $1^{\circ}$ Fica instituído o Plano Integrado de Enfrentamento ao Crack e outras Drogas, com vistas à prevenção do uso, ao tratamento e à reinserção social de usuários e ao enfrentamento do tráfico de crack e outras drogas ilícitas.

$\S 1^{0}$ As ações do Plano Integrado de Enfrentamento ao Crack e outras Drogas deverão ser executadas de forma descentralizada e integrada, por meio da conjugação de esforços entre a União, os Estados, o Distrito Federal e os Municípios, observadas a intersetorialidade, a interdisciplinaridade, a integralidade, a participação da sociedade civil e o controle social.

$\S 2^{\underline{0}}$ O Plano Integrado de Enfrentamento ao Crack e outras Drogas tem como fundamento a integração e a articulação permanente entre as políticas e ações de saúde, assistência social, segurança pública, educação, desporto, cultura, direitos humanos, juventude, entre outras, em consonância com os pressupostos, diretrizes e objetivos da Política Nacional sobre Drogas.

Art. $2^{-}$São objetivos do Plano Integrado de Enfrentamento ao Crack e outras Drogas: I - estruturar, integrar, articular e ampliar as ações voltadas à prevenção do uso, tratamento e reinserção social de usuários de crack e outras drogas, contemplando a participação dos familiares e a atenção aos públicos vulneráveis, entre outros, crianças, adolescentes e população em situação de rua;

II - estruturar, ampliar e fortalecer as redes de atenção à saúde e de assistência social para usuários de crack e outras drogas, por meio da articulação das ações do Sistema Único de Saúde - SUS com as ações do Sistema Único de Assistência Social - SUAS;

III - capacitar, de forma continuada, os atores governamentais e não governamentais envolvidos nas ações voltadas à prevenção do uso, ao tratamento e à reinserção social de usuários de crack e outras drogas e ao enfrentamento do tráfico de drogas ilícitas;

IV - promover e ampliar a participação comunitária nas políticas e ações de prevenção do uso, tratamento, reinserção social e ocupacional de usuários de crack e outras drogas e fomentar a multiplicação de boas práticas;

$\mathrm{V}$ - disseminar informações qualificadas relativas ao crack e outras drogas; e

VI - fortalecer as ações de enfrentamento ao tráfico de crack e outras drogas ilícitas em todo o território nacional, com ênfase nos Municípios de fronteira. 
Art. $3^{\circ}$ Fica instituído o Comitê Gestor do Plano Integrado de Enfrentamento ao Crack e outras Drogas, composto por um representante, titular e suplente, de cada órgão a seguir indicado:

I - Gabinete de Segurança Institucional da Presidência da República;

II - Casa Civil da Presidência da República;

III - Secretaria-Geral da Presidência da República;

IV - Secretaria de Relações Institucionais da Presidência da República;

V - Secretaria de Direitos Humanos da Presidência da República;

VI - Secretaria de Comunicação Social da Presidência da República;

VII - Secretaria de Políticas para as Mulheres da Presidência da República;

VIII - Ministério da Justiça;

IX - Ministério da Saúde;

$\mathrm{X}$ - Ministério do Desenvolvimento Social e Combate à Fome;

XI - Ministério da Defesa;

XII - Ministério da Educação;

XIII - Ministério da Cultura;

XIV - Ministério do Esporte; e

XV - Ministério do Planejamento, Orçamento e Gestão.

$\S 1^{\text {o }}$ Compete ao Gabinete de Segurança Institucional da Presidência da República e ao Ministério da Justiça a coordenação do Comitê Gestor.

$\S 2^{0}$ Os membros do Comitê Gestor serão indicados pelos titulares dos órgãos nele representados, no prazo de quinze dias contado da publicação deste Decreto, e designados pelo Ministro de Estado Chefe do Gabinete de Segurança Institucional da Presidência da República.

$\S 3^{0}$ O Comitê Gestor reunir-se-á periodicamente, mediante convocação de seus coordenadores.

$\S 4^{\underline{0}}$ Os coordenadores Comitê Gestor poderão convidar para participar de suas reuniões, representantes de outros órgãos e entidades da administração pública federal, dos Estados, do Distrito Federal e dos Municípios, dos Poderes Judiciário e Legislativo, de entidades privadas sem fins lucrativos, bem como especialistas.

$\S 5^{\circ}$ Ao Gabinete de Segurança Institucional da Presidência da República caberá prover apoio técnico-administrativo e os meios necessários à execução dos trabalhos do Comitê Gestor.

Art. $4^{\circ}$ Compete ao Comitê Gestor:

I - estimular a participação dos entes federados na implementação do Plano Integrado de Enfrentamento ao Crack e outras Drogas;

II - acompanhar e avaliar a implementação do Plano Integrado de Enfrentamento ao Crack e outras Drogas; e

III - consolidar em relatório periódico as informações sobre a implementação das ações e os resultados obtidos.

Art. $5^{\mathrm{O}} \mathrm{O}$ Plano Integrado de Enfrentamento ao Crack e outras Drogas será composto por ações imediatas e estruturantes.

$\S 1^{\underline{0}}$ As ações Imediatas do Plano Integrado de Enfrentamento ao Crack e outras Drogas contemplam: 
I - ampliação do número de leitos para tratamento de usuários de crack e outras drogas; II - ampliação da rede de assistência social voltada ao acompanhamento sociofamiliar e à inclusão de crianças, adolescentes e jovens usuários de crack e outras drogas em programas de reinserção social;

III - ação permanente de comunicação de âmbito nacional sobre o crack e outras drogas, envolvendo profissionais e veículos de comunicação;

IV - capacitação em prevenção do uso de drogas para os diversos públicos envolvidos na prevenção do uso, tratamento, reinserção social e enfrentamento ao tráfico de crack e outras drogas ilícitas;

V - ampliação das ações de prevenção, tratamento, assistência e reinserção social em regiões de grande vulnerabilidade à violência e ao uso de crack e outras drogas, alcançadas por programas governamentais como o Projeto Rondon e o Projovem;

VI - criação de sítio eletrônico no Portal Brasil, na rede mundial de computadores, que funcione como centro de referência das melhores práticas de prevenção ao uso do crack e outras drogas, de enfrentamento ao tráfico e de reinserção social do usuário;

VII - ampliação de operações especiais voltadas à desconstituição da rede de narcotráfico, com ênfase nas regiões de fronteira, desenvolvidas pelas Polícias Federal e Rodoviária Federal em articulação com as polícias civil e militar e com apoio das Forças Armadas; e

VIII - fortalecimento e articulação das polícias estaduais para o enfrentamento qualificado ao tráfico do crack em áreas de maior vulnerabilidade ao consumo.

$\S 2^{0}$ As ações estruturantes do Plano Integrado de Enfrentamento ao Crack e outras Drogas contemplam:

I - ampliação da rede de atenção à saúde e assistência social para tratamento e reinserção social de usuários de crack e outras drogas;

II - realização de estudos e diagnóstico para o acúmulo de informações destinadas ao aperfeiçoamento das políticas públicas de prevenção do uso, tratamento e reinserção social do usuário e enfrentamento do tráfico de crack e outras drogas ilícitas;

III - implantação de ações integradas de mobilização, prevenção, tratamento e reinserção social nos Territórios de Paz do Programa Nacional de Segurança Pública com Cidadania - PRONASCI, e nos territórios de vulnerabilidade e risco;

IV - formação de recursos humanos e desenvolvimento de metodologias, envolvendo a criação de programa de especialização e mestrado profissional em gestão do tratamento de usuários de crack e outras drogas;

V - capacitação de profissionais e lideranças comunitárias, observando os níveis de prevenção universal, seletiva e indicada para os diferentes grupos populacionais;

VI-criação e fortalecimento de centros colaboradores no âmbito de hospitais universitários, que tenham como objetivos o ensino, a pesquisa e o desenvolvimento de metodologia de tratamento e reinserção social para dependentes de crack e outras drogas;

VII - criação de centro integrado de combate ao crime organizado, com ênfase no narcotráfico, em articulação com o Centro Gestor e Operacional do Sistema de Proteção da Amazônia - CENSIPAM, com apoio das Forças Armadas; 
VIII - capacitação permanente das polícias civis e militares com vistas ao enfrentamento do narcotráfico nas regiões de fronteira; e

IX - ampliação do monitoramento das regiões de fronteira com o uso de tecnologia de aviação não tripulada.

$\S 3^{\mathrm{o}}$ O Plano Integrado de Enfrentamento ao Crack e outras Drogas promoverá, ainda, a articulação das ações definidas neste artigo com outras ações desenvolvidas em âmbito federal, estadual, distrital e municipal.

Art. 6 ${ }^{0}$ As despesas decorrentes da implementação do Plano Integrado de Enfrentamento ao Crack e outras Drogas correrão à conta de dotações orçamentárias próprias dos órgãos nele representados, consignadas anualmente nos respectivos orçamentos, observados os limites de movimentação, de empenho e de pagamento da programação orçamentária e financeira anual.

Art. $7^{0}$ A execução das ações previstas neste Plano observará as competências previstas no Decreto $\mathrm{n}^{0} 5.912$, de 27 de setembro de 2006.

Art. $8^{0}$ Este Decreto entra em vigor na data de sua publicação.

Brasília, 20 de maio de 2010; 189ํํำ da Independência e $122^{\circ}$ da República.

\section{LUIZ INÁCIO LULA DA SILVA}

Luiz Paulo Teles Ferreira Barreto

Fernando Haddad

Márcia Bassit Lameiro da Costa Mazzoli

Márcia Helena Carvalho Lopes

Jorge Armando Felix 
Anexo 5 - Texto de Apoio

Álcool e outras drogas como desafio para a saúde e as políticas intersetoriais - contribuições para a IV Conferência Nacional de Saúde Mental - Intersetorial ${ }^{1}$

Márcia Landini Totugui

Miriam Di Giovanni

Francisco Cordeiro

Marcelo Kimati Dias

Pedro Gabriel Godinho Delgado

${ }^{1}$ In Desafios políticos da reforma psiquiátrica brasileira, Vasconcelos,

E. M., São Paulo: Editora Hucitec. 2010. pp 93-113. 


\section{Introdução}

A expansão do uso de cocaína na forma de crack constitui um fenômeno complexo e contemporâneo. Ainda que não saibamos a extensão do aumento do consumo, sabe-se que, ainda que haja informações que apontam para o aumento do consumo em camadas de classe média, populações mais vulneráveis, em particular moradores de rua, estão mais expostos ao uso. A ampla divulgação do fenômeno na mídia faz, de uma forma geral, que o consumo de crack seja adornado por inúmeros adjetivos potencialmente criadores de pânico. Outro fenômeno que acompanha o aumento do consumo de crack diz respeito ao grande número de estigmas e preconceitos relacionados à droga e seus usuários.

A questão do uso de drogas, inclusive do crack, tem sido comumente tratada e entendida de forma simplista, inclusive por profissionais da saúde. A conseqüência disso é a tendência de avaliação moral do consumo. A visão reducionista implica ainda na tendência a abordagens também reducionistas aos usuários. Por um lado, na medida em que tais estratégias são frequentemente ineficazes, por outro ajudam a desenvolver barreiras de acesso aos cuidados de saúde. Como se sabe, as drogas fazem parte da história da humanidade, o homem sempre as usou para as mais variadas finalidades, em diferentes contextos e sentidos. Especialistas apontam que as políticas proibicionistas ou de extinção das drogas não demonstram funcionalidade e eficácia. A complexidade do fenômeno de uso de drogas aponta para a necessidade de desenvolver propostas de ações também complexas, interdisciplinares e intersetoriais.

O crack ocupa os cenários urbanos de nosso país há mais ou menos 20 anos. Hoje se observa sua interiorização com espaço em cidades de médio e pequeno porte. Gestores de saúde mental relatam aumento no consumo de crack em regiões que outrora não apresentavam presença significativa da droga, em especial no nordeste e nas cidades fora dos grandes centros urbanos. $\mathrm{O}$ aumento parece estar relacionado com o baixo custo e as características dos efeitos procurados, embora sejam necessários estudos e pesquisa sobre a influência desses ou outros fatores.

O panorama mundial da difusão do uso do cloridrato de cocaína (pó) por aspiração intranasal esteve associado, a partir da década de 60, à falta de algumas drogas no mercado, como a anfetamina e a maconha, devido às ações repressivas. 
Contudo, o alto preço do produto levou usuários de drogas à descoberta de outras formas de uso com efeitos mais intensos, apesar de menor duração. Desse cenário, no início de 1980, aparecem novas drogas obtidas a partir da mistura de cloridrato de cocaína com ingredientes cada vez mais incertos e tóxicos. Tempos depois, surge o uso do crack, outra forma fumável de cocaína, disseminando-se no Brasil, oficialmente a partir de 1989, alastrando-se atualmente, em vários segmentos sociais de gênero, sexo, idade e classe social.

Na produção de crack não há o processo de purificação final. O cloridrato de cocaína é dissolvido em água e adicionado em bicarbonato de sódio. Essa mistura é aquecida e, quando seca, adquire a forma de pedras duras e fumáveis. Além dos alcalóides de cocaína e bicarbonato de sódio, essas pedras contêm as sobras de todos os ingredientes que já haviam sido adicionados anteriormente durante o refino da cocaína. As pedras de crack são vendidas já prontas para serem fumadas. Sua composição conta com uma quantidade imprecisa de cocaína, suficiente para que possa produzir efeitos fortes e intensos. Além disso, para obter a produção final do crack são misturadas à cocaína diversas substâncias tóxicas como gasolina, querosene e até água de bateria.

A entrada do crack no mercado das drogas está relacionada a vários fatores que levaram a uma grave transformação, tanto na oferta quanto na procura. De um lado, o controle mundial e nacional repressivo sobre os insumos químicos necessários a sua produção - como éter e acetona - leva os produtores a baratear cada vez mais sua fabricação, com a utilização indiscriminada de outros ingredientes altamente impuros. Quanto mais barata sua produção, mais rentável é sua venda. Por outro lado, o crack representa para a população usuária de drogas um tipo de cocaína acessível, pois vendido em pequenas unidades baratas, oferece efeitos rápidos e intensos. Entretanto, a desejada intoxicação cocaínica proporcionada pelo crack provoca efeitos de pouca duração, o que leva o usuário a fumar imediatamente outra pedra, fenômeno entendido como fissura. Esse ciclo ininterrupto de uso potencializa os prejuízos à saúde física, as possibilidades de dependência e os danos sociais. A inovação no mercado das drogas com a entrada do crack atraiu pequenos traficantes, agravou ainda mais a situação, com o aumento incontrolável de produções caseiras, se diferenciando conforme a região do país.

À cocaína é misturada uma variedade incerta de reagentes químicos em sua preparação. O desconhecimento quanto a sua composição pode dificultar, muitas vezes, 
as intervenções emergenciais de cuidados à saúde nos casos de intoxicação aguda sofrida por alguns usuários. Tais condições, porém, não impossibilitam o desenvolvimento de ações voltadas à saúde e ao bem-estar social da referida população. O crack é fumado por ser uma forma mais rápida (e barata) de a droga chegar ao cérebro e produzir seus efeitos. A pedra é quebrada e fumada de diversas maneiras e em diferentes recipientes: enrolada no cigarro de tabaco ou misturada na maconha - forma que parece amenizar psiquicamente os efeitos maléficos da droga, como o sentimento de perseguição, a agitação motora e posteriormente a depressão. É também fumado em cachimbos improvisados feitos em tubos de PVC ou em latas de alumínio muitas vezes coletados na rua ou no lixo, apresentando possibilidades de contaminação infecciosa. O uso de latas favorece a aspiração de grande quantidade de fumaça pelo bocal, promovendo intoxicação pulmonar muito intensa.

São vários os tipos de danos causados pelo uso de crack. Além dos problemas respiratórios pela inspiração de partículas sólidas, sua ação estimulante leva à perda de apetite, falta de sono e agitação motora e, a dificuldade de ingestão de alimentos pode levar à desnutrição, desidratação e gastrite. Podem ser ainda observados sintomas físicos como rachadura nos lábios pela falta de ingestão de água e de salivação, cortes e queimaduras nos dedos das mãos e às vezes no nariz, provocados pelo ato de quebrar e acender a pedra, além de ficar o usuário mais exposto ao risco social e de doenças. O cenário epidemiológico do crack no Brasil, segundo o CEBRID, aponta:

Tabela 1. População geral, cidades com mais de 200.000 habitantes (2001 e 2005)

\begin{tabular}{|l|l|l|l|l|l|l|}
\hline \multicolumn{2}{|l|}{2001} & \multicolumn{2}{l|}{2005} \\
\hline & homens & mulheres & total & homens & mulheres & total \\
\hline $\begin{array}{l}\text { Crack: uso na } \\
\text { vida (\%) }\end{array}$ & 0,7 & 0,2 & 0,4 & 1,5 & 0,2 & 0,7 \\
\hline
\end{tabular}


Tabela 2. Estudantes de 10 a 19 anos, ensino fundamental e médio da rede pública de ensino, (2004) - padrão de consumo de crack

\begin{tabular}{|l|l|l|}
\hline Padrão de uso & $\%$ \\
\hline Uso na vida & 0,7 \\
\hline Uso no ano & 0,7 \\
\hline Uso no mês & & 0,5 \\
\hline $\begin{array}{l}\text { Uso freqüente* 6 ou mais vezes nos } \\
\text { últimos 30 dias }\end{array}$ & 0,1 \\
\hline $\begin{array}{l}\text { Uso pesado** 20 ou mais vezes nos } \\
\text { últimos 30 dias }\end{array}$ & 0,1 \\
\hline
\end{tabular}

Tabela 3. Crianças e adolescentes, de 9 a 18 anos, em situação de rua (27 capitais brasileiras - 2003)

\begin{tabular}{|l|l|}
\hline Uso no ano & $8,6 \%$ \\
\hline Uso no mês & $5,5 \%$ \\
\hline
\end{tabular}

\section{Atenção em saúde mental aos usuários de crack}

\subsection{Tipologia de caracterização dos usuários de crack}

Todo uso de drogas está associado a fatores sociais, culturais, psíquicos e biológicos e o consumo de crack não é diferente. Além dos problemas físicos já descritos, há os de ordem psicológica, social e legal. Ocorrem graves perdas nos vínculos familiares, nos espaços relacionais, nos estudos e no trabalho, bem como a troca de sexo por drogas e, ainda, podendo chegar à realização de pequenos delitos para a aquisição da droga. Há controvérsia se tais condutas socialmente desaprovadas têm relação com o estado de "fissura" para usar ou se resulta da própria intoxicação. A unanimidade é que o usuário desemboca numa grave e complexa exclusão social.

Existe uma tendência a homogeneizar usuários de crack, além de associá-los ao tráfico, violência e risco, o que contribui para diminuir o acesso dessa população aos cuidados de saúde. Profissionais da área reafirmam a grande heterogeneidade entre os usuários, especialmente em relação aos impactos de ruptura de laços sociais decorrentes do uso.

Como forma de sistematizar e criar referências para abordagem do fenômeno de uso de crack, proprõe-se uma caracterização do usuário para avaliar diretrizes da oferta de cuidados pela rede de atenção em saúde mental. Esta caracterização tem um aspecto pragmático e serve como ferramenta de avaliação para profissionais da rede de atenção. A caracterização de usuários de crack a partir da tipologia descrita abaixo ajuda a 
sistematizar a população alvo das ações emergenciais e elaborar o planejamento dos investimentos de ampliação e diversificação das ofertas de cuidado. Estas categorias são necessárias não no sentido de criar categorias diagnósticas, mas de construir estratégias intersetoriais diversificadas para um problema em freqüente transformação.

Os aspectos definidos com os mais significativos na orientação quanto a utilização da rede de atenção foram:

a) Funcionalidade- estipula o quanto o usuário de crack apresentou rupturas em sua vida social em decorrência do uso da substância. Neste sentido, usuários podem ser funcionais ou disfuncionais. Ainda que o crack se constitua uma substância com grande potencial de desenvolvimento de dependência, existe uma porcentagem de usuários da substância que apresentam menos danos funcionais. Esta categoria de usuários apresenta menos rupturas com sua rede de relações social, trabalho, família. Estudos apontam para o fato de que parte dos usuários de crack utiliza a substância também sem grandes rupturas com a funcionalidade social. Com base neste achado, dividimos os usuários em duas categorias: funcionais e disfuncionais. É importante que aos usuários funcionais sejam oferecidas condições de suporte social e de rede de cuidados para que se mantenham na funcionalidade. As ações de saúde mental, tanto na atenção básica, nos hospitais, quanto nos CAPS, estarão voltadas aos usuários disfuncionais na medida em que estes constituem um grupo com um maior risco de agravos e maior vulnerabilidade. A ruptura com as redes de relação social tende, por sua vez, dificultar a diminuição do consumo de substâncias.

b) Vulnerabilidade- identifica os usuários como mais propensos aos agravos do uso, incluindo não só agravos físicos como sociais. Característica que implica no risco do usuário de crack em apresentar agravos de todas as ordens decorrentes do uso da droga. Diversos elementos interferem na vulnerabilidade do usuário, entre elas elencamos:

B1) Gênero- usuárias do sexo feminino são mais vulneráveis a abuso sexual e agravos de ordem física. O consumo de crack pode associar-se ainda com prostituição, que implica no aumento de riscos.

B2) Idade- usuários jovens e adultos jovens apresentam um uso de crack mais frequentemente associado a processos disruptivos em relação à sua vida social. Características ainda de impulsividade podem implicar em agravos relativos ao consumo. 
B3) Vínculo com instituições (família, trabalho) e inserção no trabalho formal ou informal- usuários de crack que mantêm uma rede de apoio social e vinculações formais no mercado de trabalho têm mais recursos de acesso ao cuidado.

B4) Escolaridade- baixa escolaridade implica, entre outros aspectos, em menor inserção no mercado formal, menor disponibilidade financeira e, consequentemente, maior vulnerabilidade.

B5) Co-morbidades- co-morbidades psiquiátricas como transtornos de humor ou quadros psicóticos implicam frequentemente em pior prognóstico em avaliações prospectivas.

B6) Delitos, Conflito com a lei- situações de ilegalidade, especialmente associação com tráfico implica numa maior exposição à violência e portanto a maior vulnerabilidade.

B7) Conflito com tráfico- dívidas com tráfico, especialmente, implicam em maior vulnerabilidade.

c) Relação com o cuidado- identifica as formas de acesso ao cuidado, não só aos serviços de saúde, mas também à rede de apoio social. Diz respeito também à oferta de cuidado, não só ao usuário. Usuários de crack com dificuldade de acessar ajuda apresentam maior risco de agravos, sendo prioridade das ações de saúde mental. As redes aqui referenciadas não se limitam a ações públicas, mas incluem redes de apoio informais ligados à cultura local. O não-acesso a estas redes pode decorrer da ruptura das relações sociais relativas ao uso de crack ou do estigma relacionado ao usuário de crack. Entendemos que existe um déficit no acesso universal ao SUS por parte desta população por despreparo das equipes de saúde, especialmente na atenção básica, em acolherem as demandas destes usuários. Desta forma, ampliação do acesso é visto como uma prioridade nas ações de saúde mental em relação a este usuário.

Os usuários disfuncionais em condição de extrema vulnerabilidade pessoal e social (por se encontrarem com freqüência em situação de rua), num processo de ampla ruptura das relações sociais e com pouco acesso ao cuidado constituem hoje um grupo de 15 a 25 mil pessoas. Por outro lado, a população geral de usuários de crack $0,1 \%$ a $0,2 \%$ da população geral (CEBRID, 2005). 


\subsection{Princípios básicos orientadores da atenção aos usuários de crack}

$\mathrm{O}$ atendimento ao usuário funcional ou disfuncional de crack deve considerar alguns importantes critérios:

a) O usuário que não procura tratamento: a ele devem ser dirigidas estratégias de assistência e cuidados, de redução de danos e de riscos sociais e à saúde. As ações devem ser oferecidas e articuladas por uma rede pública de serviços de saúde e de ações sociais e devem ser feitas por equipes itinerantes, como os consultórios de rua, que busquem ativamente ampliar o acesso aos cuidados em saúde e em saúde mental destes usuários. A perspectiva dessa abordagem objetiva a inserção da promoção da saúde como também as possibilidades de inserção social.

b) A porta de entrada na rede de atenção em saúde deve ser a Estratégia de Saúde Família e os Centros de Atenção Psicossocial (CAPS). Estes serviços especializados devem ser os organizadores das demandas de saúde mental no território. Os CAPS devem dar apoio especializado às ESF, fazer articulações intersetoriais (educação, assistência social, justiça, cultura, entre outros), facilitar a articulação entre os diferentes serviços da rede, tais como ambulatórios de saúde mental, residências terapêuticas, atenção básica e leitos de atenção integral, além de encaminhar e acompanhar os usuários à internação em hospitais gerais, quando necessário.

c) Quando o usuário acessa as equipes de saúde e de saúde mental, é necessária uma avaliação clínica das suas condições de saúde física e mental, para a definição das intervenções terapêuticas que devem ser desenvolvidas. É importante que se faça uma avaliação de risco pelas equipes de saúde para se subsidiar intervenções sociais e de saúde.

d) A internação deve ser de curta duração, em hospital geral da rede pública, com vistas à desintoxicação associada aos cuidados emergenciais das complicações orgânicas e/ou à presença de algum tipo de co-morbidade desenvolvida com o uso. É concebível e muito comum que usuários de crack, ainda que num padrão de uso preocupante, resistam à internação e optem pela desintoxicação e cuidados clínicos em regime aberto, acompanhado nos CAPS AD por uma equipe interdisciplinar, nos níveis de atendimento intensivo, semi-intensivo e até 
o não intensivo. Nesse caso, a boa evolução clínica, psíquica e social dependerá da articulação inter e intrasetorial das redes de apoio, inclusive e se possível, com mobilização familiar.

e) A decisão pela internação deve ser compreendida como parte do tratamento, atrelada a um projeto terapêutico individual e, assim como a alta hospitalar e o pós-alta, deve ser de natureza interdisciplinar. Intervenções e procedimentos isolados mostram-se ineficazes, com pouca adesão e curta duração, além de favorecer o descrédito e desalento da família e mais estigma ao usuário.

\subsection{Rede de Saúde e Atenção aos Usuários de Crack}

A atenção a usuários de crack no SUS tem como referência o constante diálogo e articulação entre os diferentes serviços. Devem ser construídos, tanto no âmbito municipal quanto regional, fluxos transversais e intersetoriais, considerando uma atenção em rede, de forma a facilitar e promover a circulação dos usuários nos serviços necessários. A atenção em rede implica num conjunto de dispositivos com funções complementares, mas sem papéis estanques ou fluxos burocráticos. Ao contrário, a rede de atenção deve ser mobilizada a partir de demandas específicas de cada usuário do sistema. E cada uma destas necessidades deve ser contemplada à partir de um projeto individual que defina como a rede de atenção deve ser mobilizada. Desta forma, a descrição dos componentes desta rede deve ser entendida como uma configuração dinâmica, com cada um dos dispositivos atuando de forma flexível de acordo com as demandas dos usuários da rede. Desta forma, a avaliação interdisciplinar e o acolhimento dos usuários de crack devem ser realizados de forma universal nos serviços de saúde. Por outro lado, as diferentes instâncias de cuidados têm especificidades que devem ser apontadas:

a. Atenção básica (via ESF e NASF, com participação de profissionais de $\mathrm{AD})$. A atenção básica é reconhecidamente a porta de entrada do usuário de crack no SUS e deve estar disponível para realizar seu acolhimento. A atenção básica deve realizar ofertas de cuidado a usuários funcionais, identificando aqueles com historia da ruptura de seus laços sociais e articulando-se aos CAPS do município para desenvolvimento de projetos terapêuticos individuais. Uma vez que apresenta grande capilaridade com a comunidade, pode estrategicamente desempenhar o mapeamento e 
identificação de usuários disfuncionais e, em articulação com as equipes dos CAPS. Pode ainda propor abordagens para estes usuários, especialmente aquelas ligadas a ações de redução de danos.

Experiências de ações em prevenção e assistência de usuários de crack através do núcleo de apoio à saúde da família (NASF) apontam para a possibilidade de atuação deste profissional como articulador de projetos terapêuticos de caráter interdisciplinar e intersetorial junto ao PSF. Estas ações devem sempre ter como característica agregar pessoas da equipes de saúde da família às ações com o objetivo de constituírem procedimentos de capacitação para a abordagem de usuários de crack. Um profissional do NASF tem ainda a possibilidade de articular ações intersetoriais, de identificação de casos, oferta de assistência, redução de danos e prevenção, junto a escolas, igrejas, associação de bairros, conselho local de saúde e outros segmentos da comunidade local.

b. CAPS $A D$ - acolhimento nos níveis intensivo, semi-intensivo até não intensivo - O cuidado ofertado tem como característica se efetivar por uma rede.

c. Leitos de atenção integral: hospital geral, CAPS AD 24 horas- são dispositivos que permitem o cuidado intensivo para usuários que apresentam quadro de muita gravidade e/ou vulnerabilidade. Leitos em hospitais gerais envolvem especialmente agravos clínicos, como quadros de abstinência, pneumonia, arritmias secundárias ao uso de crack. Leitos em CAPS têm como grande vantagem permitirem que o usuário seja acompanhado em período de crise pela mesma equipe que o acompanhou de forma diária, fora da crise. O leito pode ser utilizado também como recurso de redução de danos ou prevenção à recaída.

d. Consultórios de rua: são dispositivos públicos componentes da rede de atenção substitutiva em saúde mental, com objetivo principal de estender o cuidado a usuários de álcool e outras drogas em situação de rua, historicamente desassistidos e distantes dos serviços de saúde. As ações de promoção, prevenção e cuidados primários são realizadas in loco, fora de ambientes institucionalizados. As abordagens privilegiam a redução de danos como estratégia de aproximação e cuidado destes usuários. 
e. Casas de Acolhimento Transitório: Experiência desenvolvida em Recife com o nome de Casas do Meio do Caminho ou Casas de Passagem. Consistem em casas de albergamento de usuários da rede de atenção psicossocial em tratamento para transtornos relacionados ao uso de álcool e outras drogas. As Casas de Acolhimento Transitório procuram ampliar os recursos da rede em oferecer a estes usuários cuidados contínuos para populações em estado de vulnerabilidade e riscos. Funcionam como albergues 24 horas que potencializam as ações de saúde mental da rede de atenção, dando maior institucionalidade e continuidade ao cuidado. Sua utilização, na experiência de Recife, é vinculada a um projeto terapêutico que define o tempo de uso do recurso e o objetivo desta utilização. Casas de Acolhimento Transitório podem proporcionar aos usuários de álcool e outras drogas em situação de extrema vulnerabilidade e riscos sociais e de saúde a chance de receber uma intervenção breve ou iniciar um tratamento, protegido das drogas, seja a curto ou médio prazo, que respeite seu contexto social e familiar, sua capacidade e disponibilidade de adesão, ou seu desejo de interromper ou apenas reduzir seu consumo.

f. Ponto de Acolhimento: tem como finalidade proporcionar um primeiro contato com usuários de substância que não têm qualquer acesso a cuidados relativos a álcool e outras drogas. São espaços abertos, onde estes usuários podem alimentar-se, descansar e onde, são feitas ofertas de promoção de saúde e redução de danos. Trata-se de espaços de gestão intersetorial, com caráter territorial.

g. Estratégias de redução de danos

h. Articulação com outras Políticas Públicas: Ação Social, Educação, Trabalho, Justiça, Esporte, Direitos Humanos, Moradia.

\section{Considerações Finais}

A abordagem terapêutica do crack traz à tona diversos desafios atuais da reforma psiquiátrica. Em primeiro lugar, resgata a complexidade que deve ser considerada nas abordagens. $\mathrm{O}$ uso de drogas é um fenômeno que vai muito além do efeito psicotrópico da substância, envolvendo questões culturais, de identificação de grupo e tem uma 
relação íntima com o território, considerando este termo em toda sua complexidade. Este aspecto do uso de drogas demanda, da saúde pública, saídas também complexas e estas apontam sempre para a necessidade de incorporar diversos outros parceiros e práticas de cuidado fora da saúde mental.

Este é o segundo desafio que a questão do uso de drogas traz à tona. $\mathrm{O}$ fenômeno demanda que os trabalhadores de saúde mental passem a desenvolver práticas em articulação interdisciplinar e intersetorial. Este é um processo em desenvolvimento nas práticas de saúde mental e deve romper com a tradição histórica de isolamento do cotidiano dos serviços. O diálogo e a necessidade de desenvolvimento de parcerias fora da área implicam nos trabalhadores de saúde mental se defrontarem com a alteridade. Este processo é positivo na medida em que marca uma expansão das concepções ligadas à reforma psiquiátrica. Com a expansão do número de profissionais e no número de categorias profissionais envolvidas com a atenção a usuários de drogas passa a existir um crescimento no número de atores envolvidos com o ideário que referencia este atenção. E na medida em que isso acontece, a reforma ampliando seu caráter de política nacional de saúde e ganha um caráter sócio-cultural.

\section{Referências}

Andrade TM, Lurie P, Medina MG, Anderson K e Dourado I. The Opening of South America's First Needle Exchange Program and an Epidemic of Crack Use in Salvador, Bahia-Brazil. AIDS and Behaviour Volume 5, Number 1/ March, 2001. Andrade, TM. Condiçöes psicossociais e exposiçäo ao risco de infecçäo pelo HIV entre usuários de drogas infetáveis, em uma comunidade marginalizada de SalvadorBahia. Apresentada a Universidade Federal da Bahia. Faculdade de Medicina para obtenção do grau de Doutor. Salvador, 1996.

Andrade, AG, Leite, MC e col. Cocaína e crack: dos fundamentos ao tratamento. Porto Alegre: Artes Médicas, 1999.

Carvalho, Heraclito Barbosa de and Seibel, Sergio Dario. Crack cocaine use and its relationship with violence and HIV. Clinics [online]. 2009, vol.64, n.9, pp. 857-866.

Carlini EA, Galduróz JCF, Noto AR, Nappo AS. I Levantamento Domiciliar sobre o Uso de Drogas Psicotrópicas no Brasil: Estudo Envolvendo as 107 Maiores Cidades do País - 2001 - CEBRID - Centro Brasileiro de Informações Sobre Drogas Psicotrópicas : UNIFESP - Universidade Federal de São Paulo, 2002. 
Domanico, A. \& MacRae, E. Estratégias de Redução de Danos entre Usuários de Crack. In: Silveira, D. X. \& Moreira, F. G. Panorama Atual de Drogas e Dependências. São Paulo: Ed. Atheneu, 2006.

Governo de São Paulo. SOS crack: prevenção e tratamento, diretrizes e resumos de trabalhos, 1999.

Nappo SA, Galduróz JC, Raymundo M, Carlini EA. Changes in cocaine use as viewed by key informants: a qualitative study carried out in 1994 and 1999 in São Paulo, Brazil.Journal of Psychoactive Drugs. 2001 Jul-Sep;33(3):241-53.

Silva, SL. Mulheres da luz: uma etnografia dos usos e da preservação no uso do crack. Dissertação apresentada para obtenção de título de mestre em Saúde Pública. Faculdade de Saúde Pública/USP, 2000.

Silveira, DX, Labigalini E. e Rodrigues, LR Redução de danos no uso de maconha por dependentes de crack. In: SOS crack prevenção e tratamento. Governo do Estado de São Paulo, 1998.

Totugui ML. Possibilidades Integradoras da Redução de Danos na Teoria da Complexidade: Estudo Teórico-Clínico para Psicoterapia de Dependentes de Drogas. Dissertação apresentada para obtenção de título de mestre em psicologia clínica e cultura. UNB, 2009. 


\author{
ANEXO 5 \\ CONSELHO FEDERAL DE MEDICINA \\ RESOLUÇÃO CFM No 1.931, DE 17 DE SETEMBRO DE 2009 \\ Diário Oficial da União; Poder Executivo, Brasília, DF, 24 set. 2009. Seção I, p.90-92 \\ Diário Oficial da União; Poder Executivo, Brasília, DF, 13 out. 2009. Seção I, p.173 - RETIFICAÇÃO \\ EM VIGOR A PARTIR DE 13-04-2010 \\ REVOGA A RESOLUCÃ̃O CFM No 1.246, DE 08-01-1988
}

Aprova o Código de Ética Médica.

O CONSELHO FEDERAL DE MEDICINA, no uso das atribuições conferidas pela Lei n..$^{\circ} 3.268$, de 30 de setembro de 1957 , regulamentada pelo Decreto $\mathrm{n} .^{\circ}$ 44.045 , de 19 de julho de 1958 , modificado pelo Decreto $n .^{\circ} 6.821$, de 14 de abril de 2009 e pela Lei n. ${ }^{\circ} 11.000$, de 15 de dezembro de 2004 , e, consubstanciado nas Leis n. ${ }^{\circ} 6.828$, de 29 de outubro de 1980 e Lei n. ${ }^{\circ} 9.784$, de 29 de janeiro de 1999; e

CONSIDERANDO que os Conselhos de Medicina são ao mesmo tempo julgadores e disciplinadores da classe médica, cabendo-lhes zelar e trabalhar, por todos os meios ao seu alcance, pelo perfeito desempenho ético da Medicina e pelo prestígio e bom conceito da profissão e dos que a exerçam legalmente;

CONSIDERANDO que as normas do Código de Ética Médica devem submeter-se aos dispositivos constitucionais vigentes;

CONSIDERANDO a busca de melhor relacionamento com o paciente e a garantia de maior autonomia à sua vontade;

CONSIDERANDO as propostas formuladas ao longo dos anos de 2008 e 2009 e pelos Conselhos Regionais de Medicina, pelas Entidades Médicas, pelos médicos e por instituições científicas e universitárias para a revisão do atual Código de Etica Médica;

CONSIDERANDO as decisões da IV Conferência Nacional de Ética Médica que elaborou, com participação de Delegados Médicos de todo o Brasil, um novo Código de Ética Médica revisado.

CONSIDERANDO o decidido pelo Conselho Pleno Nacional reunido em 29 de agosto de 2009;

CONSIDERANDO, finalmente, o decidido em sessão plenária de 17 de setembro de 2009.

RESOLVE:

Art. $1^{\circ}$ Aprovar o Código de Ética Médica, anexo a esta Resolução, após sua revisão e atualização. 
Art. $2^{\circ} 0$ Conselho Federal de Medicina, sempre que necessário, expedirá Resoluções que complementem este Código de Ética Médica e facilitem sua aplicação.

Art. $3^{\circ} \mathrm{O}$ Código anexo a esta Resolução entra em vigor cento e oitenta dias após a data de sua publicação e, a partir daí, revoga-se o Código de Ética Médica aprovado pela Resolução CFM n. ${ }^{\circ} 1.246$, publicada no Diário Oficial da União, no dia 26 de janeiro de 1988, Seção I, páginas 1574-1579, bem como as demais disposições em contrário.

\section{EDSON DE OLIVEIRA ANDRADE \\ Presidente}

LÍVIA BARROS GARÇÃO

Secretária-Geral

\section{CÓDIGO DE ÉTICA MÉDICA}

\section{PREÂMBULO}

I - O presente Código de Ética Médica contém as normas que devem ser seguidas pelos médicos no exercício de sua profissão, inclusive no exercício de atividades relativas ao ensino, à pesquisa e à administração de serviços de saúde, bem como no exercício de quaisquer outras atividades em que se utilize o conhecimento advindo do estudo da Medicina.

II - As organizações de prestação de serviços médicos estão sujeitas às normas deste Código.

III - Para o exercício da Medicina, impõe-se a inscrição no Conselho Regional do respectivo Estado, Território ou Distrito Federal. (vIDE RETIFICACÃ̃o CONFORME DOU DE 13-10-2009)

IV - A fim de garantir o acatamento e a cabal execução deste Código, o médico comunicará ao Conselho Regional de Medicina, com discrição e fundamento, fatos de que tenha conhecimento e que caracterizem possível infração do presente Código e das demais normas que regulam o exercício da Medicina.

V - A fiscalização do cumprimento das normas estabelecidas neste Código é atribuição dos Conselhos de Medicina, das comissões de ética e dos médicos em geral.

VI - Este Código de Ética Médica é composto de 25 princípios fundamentais do exercício da Medicina, 10 normas diceológicas, 118 normas deontológicas e quatro disposições gerais. A transgressão das normas deontológicas sujeitará 
os infratores às penas disciplinares previstas em lei. (VIDE RETIFICACÃ̃o CONFORME DOU DE 13-10-2009)

\section{Capítulo I}

\section{PRINCÍPIOS FUNDAMENTAIS}

I - A Medicina é uma profissão a serviço da saúde do ser humano e da coletividade e será exercida sem discriminação de nenhuma natureza.

II - O alvo de toda a atenção do médico é a saúde do ser humano, em benefício da qual deverá agir com o máximo de zelo e o melhor de sua capacidade profissional.

III - Para exercer a Medicina com honra e dignidade, o médico necessita ter boas condições de trabalho e ser remunerado de forma justa.

IV - Ao médico cabe zelar e trabalhar pelo perfeito desempenho ético da Medicina, bem como pelo prestígio e bom conceito da profissão.

$\mathrm{V}$ - Compete ao médico aprimorar continuamente seus conhecimentos e usar o melhor do progresso científico em benefício do paciente.

VI - O médico guardará absoluto respeito pelo ser humano e atuará sempre em seu benefício. Jamais utilizará seus conhecimentos para causar sofrimento físico ou moral, para o extermínio do ser humano ou para permitir e acobertar tentativa contra sua dignidade e integridade.

VII - O médico exercerá sua profissão com autonomia, não sendo obrigado a prestar serviços que contrariem os ditames de sua consciência ou a quem não deseje, excetuadas as situações de ausência de outro médico, em caso de urgência ou emergência, ou quando sua recusa possa trazer danos à saúde do paciente.

VIII - O médico não pode, em nenhuma circunstância ou sob nenhum pretexto, renunciar à sua liberdade profissional, nem permitir quaisquer restrições ou imposições que possam prejudicar a eficiência e a correção de seu trabalho.

IX - A Medicina não pode, em nenhuma circunstância ou forma, ser exercida como comércio.

$X$ - O trabalho do médico não pode ser explorado por terceiros com objetivos de lucro, finalidade política ou religiosa.

XI - O médico guardará sigilo a respeito das informações de que detenha conhecimento no desempenho de suas funções, com exceção dos casos previstos em lei. 
XII - O médico empenhar-se-á pela melhor adequação do trabalho ao ser humano, pela eliminação e pelo controle dos riscos à saúde inerentes às atividades laborais. (VIDE RETIFICACÁ̃O CONFORME DOU DE 13-10-2009)

XIII - O médico comunicará às autoridades competentes quaisquer formas de deterioração do ecossistema, prejudiciais à saúde e à vida.

XIV - O médico empenhar-se-á em melhorar os padrões dos serviços médicos e em assumir sua responsabilidade em relação à saúde pública, à educação sanitária e à legislação referente à saúde.

XV - O médico será solidário com os movimentos de defesa da dignidade profissional, seja por remuneração digna e justa, seja por condições de trabalho compatíveis com o exercício ético-profissional da Medicina e seu aprimoramento técnico-científico. (VIDE RETIFICACÃO CONFORME DOU DE 13-10-2009)

XVI - Nenhuma disposição estatutária ou regimental de hospital ou de instituição, pública ou privada, limitará a escolha, pelo médico, dos meios cientificamente reconhecidos a serem praticados para o estabelecimento do diagnóstico e da execução do tratamento, salvo quando em benefício do paciente.

XVII - As relações do médico com os demais profissionais devem basear-se no respeito mútuo, na liberdade e na independência de cada um, buscando sempre o interesse e o bem-estar do paciente.

XVIII - O médico terá, para com os colegas, respeito, consideração e solidariedade, sem se eximir de denunciar atos que contrariem os postulados éticos.

XIX - O médico se responsabilizará, em caráter pessoal e nunca presumido, pelos seus atos profissionais, resultantes de relação particular de confiança e executados com diligência, competência e prudência.

XX - A natureza personalíssima da atuação profissional do médico não caracteriza relação de consumo.

XXI - No processo de tomada de decisões profissionais, de acordo com seus ditames de consciência e as previsões legais, o médico aceitará as escolhas de seus pacientes, relativas aos procedimentos diagnósticos e terapêuticos por eles expressos, desde que adequadas ao caso e cientificamente reconhecidas.

XXII - Nas situações clínicas irreversíveis e terminais, o médico evitará a realização de procedimentos diagnósticos e terapêuticos desnecessários e propiciará aos pacientes sob sua atenção todos os cuidados paliativos apropriados.

XXIII - Quando envolvido na produção de conhecimento científico, o médico agirá com isenção e independência, visando ao maior benefício para os pacientes e a sociedade. 
XXIV - Sempre que participar de pesquisas envolvendo seres humanos ou qualquer animal, o médico respeitará as normas éticas nacionais, bem como protegerá a vulnerabilidade dos sujeitos da pesquisa.

XXV - Na aplicação dos conhecimentos criados pelas novas tecnologias, considerando-se suas repercussões tanto nas gerações presentes quanto nas futuras, o médico zelará para que as pessoas não sejam discriminadas por nenhuma razão vinculada a herança genética, protegendo-as em sua dignidade, identidade e integridade.

\section{Capítulo II}

\section{DIREITOS DOS MÉDICOS}

É direito do médico:

I - Exercer a Medicina sem ser discriminado por questões de religião, etnia, sexo, nacionalidade, cor, orientação sexual, idade, condição social, opinião política ou de qualquer outra natureza.

II - Indicar o procedimento adequado ao paciente, observadas as práticas cientificamente reconhecidas e respeitada a legislação vigente.

III - Apontar falhas em normas, contratos e práticas internas das instituições em que trabalhe quando as julgar indignas do exercício da profissão ou prejudiciais a si mesmo, ao paciente ou a terceiros, devendo dirigir-se, nesses casos, aos órgãos competentes e, obrigatoriamente, à comissão de ética e ao Conselho Regional de Medicina de sua jurisdição.

IV - Recusar-se a exercer sua profissão em instituição pública ou privada onde as condições de trabalho não sejam dignas ou possam prejudicar a própria saúde ou a do paciente, bem como a dos demais profissionais. Nesse caso, comunicará imediatamente sua decisão à comissão de ética e ao Conselho Regional de Medicina.

V - Suspender suas atividades, individualmente ou coletivamente, quando a instituição pública ou privada para a qual trabalhe não oferecer condições adequadas para o exercício profissional ou não o remunerar digna e justamente, ressalvadas as situações de urgência e emergência, devendo comunicar imediatamente sua decisão ao Conselho Regional de Medicina.

$\mathrm{VI}$ - Internar e assistir seus pacientes em hospitais privados e públicos com caráter filantrópico ou não, ainda que não faça parte do seu corpo clínico, respeitadas as normas técnicas aprovadas pelo Conselho Regional de Medicina da pertinente jurisdição.

VII - Requerer desagravo público ao Conselho Regional de Medicina quando atingido no exercício de sua profissão. 
VIII - Decidir, em qualquer circunstância, levando em consideração sua experiência e capacidade profissional, o tempo a ser dedicado ao paciente, evitando que o acúmulo de encargos ou de consultas venha a prejudicá-lo.

IX - Recusar-se a realizar atos médicos que, embora permitidos por lei, sejam contrários aos ditames de sua consciência.

X- Estabelecer seus honorários de forma justa e digna.

\section{Capítulo III}

RESPONSABILIDADE PROFISSIONAL

É vedado ao médico:

Art. $1^{\circ}$ Causar dano ao paciente, por ação ou omissão, caracterizável como imperícia, imprudência ou negligência.

Parágrafo único. A responsabilidade médica é sempre pessoal e não pode ser presumida.

Art. $2^{\circ}$ Delegar a outros profissionais atos ou atribuições exclusivos da profissão médica.

Art. $3^{\circ}$ Deixar de assumir responsabilidade sobre procedimento médico que indicou ou do qual participou, mesmo quando vários médicos tenham assistido o paciente.

Art. $4^{\circ}$ Deixar de assumir a responsabilidade de qualquer ato profissional que tenha praticado ou indicado, ainda que solicitado ou consentido pelo paciente ou por seu representante legal.

Art. $5^{\circ}$ Assumir responsabilidade por ato médico que não praticou ou do qual não participou.

Art. $6^{\circ}$ Atribuir seus insucessos a terceiros e a circunstâncias ocasionais, exceto nos casos em que isso possa ser devidamente comprovado.

Art. $7^{\circ}$ Deixar de atender em setores de urgência e emergência, quando for de sua obrigação fazê-lo, expondo a risco a vida de pacientes, mesmo respaldado por decisão majoritária da categoria.

Art. $8^{\circ}$ Afastar-se de suas atividades profissionais, mesmo temporariamente, sem deixar outro médico encarregado do atendimento de seus pacientes internados ou em estado grave.

Art. $9^{\circ}$ Deixar de comparecer a plantão em horário preestabelecido ou abandoná-lo sem a presença de substituto, salvo por justo impedimento. 
Parágrafo único. Na ausência de médico plantonista substituto, a direção técnica do estabelecimento de saúde deve providenciar a substituição.

Art. 10. Acumpliciar-se com os que exercem ilegalmente a Medicina ou com profissionais ou instituições médicas nas quais se pratiquem atos ilícitos.

Art. 11. Receitar, atestar ou emitir laudos de forma secreta ou ilegível, sem a devida identificação de seu número de registro no Conselho Regional de Medicina da sua jurisdição, bem como assinar em branco folhas de receituários, atestados, laudos ou quaisquer outros documentos médicos.

Art. 12. Deixar de esclarecer o trabalhador sobre as condições de trabalho que ponham em risco sua saúde, devendo comunicar o fato aos empregadores responsáveis.

Parágrafo único. Se o fato persistir, é dever do médico comunicar o ocorrido às autoridades competentes e ao Conselho Regional de Medicina.

Art. 13. Deixar de esclarecer o paciente sobre as determinantes sociais, ambientais ou profissionais de sua doença.

Art. 14. Praticar ou indicar atos médicos desnecessários ou proibidos pela legislação vigente no País.

Art. 15. Descumprir legislação específica nos casos de transplantes de órgãos ou de tecidos, esterilização, fecundação artificial, abortamento, manipulação ou terapia genética.

$\S 1^{\circ}$ No caso de procriação medicamente assistida, a fertilização não deve conduzir sistematicamente à ocorrência de embriões supranumerários.

§ $2^{\circ} \mathrm{O}$ médico não deve realizar a procriação medicamente assistida com nenhum dos seguintes objetivos:

I - criar seres humanos geneticamente modificados;

II - criar embriões para investigação;

III - criar embriões com finalidades de escolha de sexo, eugenia ou para originar híbridos ou quimeras.

$\S 3^{\circ}$ Praticar procedimento de procriação medicamente assistida sem que os participantes estejam de inteiro acordo e devidamente esclarecidos sobre o mesmo.

Art. 16. Intervir sobre o genoma humano com vista à sua modificação, exceto na terapia gênica, excluindo-se qualquer ação em células germinativas que resulte na modificação genética da descendência. 
Art. 17. Deixar de cumprir, salvo por motivo justo, as normas emanadas dos Conselhos Federal e Regionais de Medicina e de atender às suas requisições administrativas, intimações ou notificações no prazo determinado

Art. 18. Desobedecer aos acórdãos e às resoluções dos Conselhos Federal e Regionais de Medicina ou desrespeitá-los.

Art. 19. Deixar de assegurar, quando investido em cargo ou função de direção, os direitos dos médicos e as demais condições adequadas para o desempenho ético-profissional da Medicina.

Art. 20. Permitir que interesses pecuniários, políticos, religiosos ou de quaisquer outras ordens, do seu empregador ou superior hierárquico ou do financiador público ou privado da assistência à saúde interfiram na escolha dos melhores meios de prevenção, diagnóstico ou tratamento disponíveis e cientificamente reconhecidos no interesse da saúde do paciente ou da sociedade.

Art. 21. Deixar de colaborar com as autoridades sanitárias ou infringir a legislação pertinente.

\section{Capítulo IV \\ DIREITOS HUMANOS}

É vedado ao médico:

Art. 22. Deixar de obter consentimento do paciente ou de seu representante legal após esclarecê-lo sobre o procedimento a ser realizado, salvo em caso de risco iminente de morte.

Art. 23. Tratar o ser humano sem civilidade ou consideração, desrespeitar sua dignidade ou discriminá-lo de qualquer forma ou sob qualquer pretexto.

Art. 24. Deixar de garantir ao paciente o exercício do direito de decidir livremente sobre sua pessoa ou seu bem-estar, bem como exercer sua autoridade para limitá-lo.

Art. 25. Deixar de denunciar prática de tortura ou de procedimentos degradantes, desumanos ou cruéis, praticá-las, bem como ser conivente com quem as realize ou fornecer meios, instrumentos, substâncias ou conhecimentos que as facilitem.

Art. 26. Deixar de respeitar a vontade de qualquer pessoa, considerada capaz fisica e mentalmente, em greve de fome, ou alimentá-la compulsoriamente, devendo cientificá-la das prováveis complicações do jejum prolongado e, na hipótese de risco iminente de morte, tratá-la. 
Art. 27. Desrespeitar a integridade física e mental do paciente ou utilizar-se de meio que possa alterar sua personalidade ou sua consciência em investigação policial ou de qualquer outra natureza.

Art. 28. Desrespeitar o interesse e a integridade do paciente em qualquer instituição na qual esteja recolhido, independentemente da própria vontade.

Parágrafo único. Caso ocorram quaisquer atos lesivos à personalidade e à saúde física ou mental dos pacientes confiados ao médico, este estará obrigado a denunciar o fato à autoridade competente e ao Conselho Regional de Medicina.

Art. 29. Participar, direta ou indiretamente, da execução de pena de morte.

Art. 30. Usar da profissão para corromper costumes, cometer ou favorecer crime.

\section{Capítulo V}

\section{RELAÇÃO COM PACIENTES E FAMILIARES}

É vedado ao médico:

Art. 31. Desrespeitar o direito do paciente ou de seu representante legal de decidir livremente sobre a execução de práticas diagnósticas ou terapêuticas, salvo em caso de iminente risco de morte.

Art. 32. Deixar de usar todos os meios disponíveis de diagnóstico e tratamento, cientificamente reconhecidos e a seu alcance, em favor do paciente.

Art. 33. Deixar de atender paciente que procure seus cuidados profissionais em casos de urgência ou emergência, quando não haja outro médico ou serviço médico em condições de fazê-lo.

Art. 34. Deixar de informar ao paciente o diagnóstico, o prognóstico, os riscos e os objetivos do tratamento, salvo quando a comunicação direta possa the provocar dano, devendo, nesse caso, fazer a comunicação a seu representante legal. (VIDE RETIFICACÃO CONFORME DOU DE 13-10-2009)

Art. 35. Exagerar a gravidade do diagnóstico ou do prognóstico, complicar a terapêutica ou exceder-se no número de visitas, consultas ou quaisquer outros procedimentos médicos.

Art. 36. Abandonar paciente sob seus cuidados.

$\S 1^{\circ}$ Ocorrendo fatos que, a seu critério, prejudiquem o bom relacionamento com o paciente ou o pleno desempenho profissional, o médico tem o direito de renunciar ao atendimento, desde que comunique previamente ao paciente 
ou a seu representante legal, assegurando-se da continuidade dos cuidados e fornecendo todas as informações necessárias ao médico que lhe suceder.

$\S 2^{\circ}$ Salvo por motivo justo, comunicado ao paciente ou aos seus familiares, 0 médico não abandonará o paciente por ser este portador de moléstia crônica ou incurável e continuará a assisti-lo ainda que para cuidados paliativos.

Art. 37. Prescrever tratamento ou outros procedimentos sem exame direto do paciente, salvo em casos de urgência ou emergência e impossibilidade comprovada de realizá-lo, devendo, nesse caso, fazê-lo imediatamente após cessar o impedimento. (VIDE RETIFICACÃO CONFORME DOU DE 13-10-2009)

Parágrafo único. 0 atendimento médico a distância, nos moldes da telemedicina ou de outro método, dar-se-á sob regulamentação do Conselho Federal de Medicina. (VIDE RETIFICACÃA CONFORME DOU DE 13-10-2009)

Art. 38. Desrespeitar o pudor de qualquer pessoa sob seus cuidados profissionais.

Art. 39 Opor-se à realização de junta médica ou segunda opinião solicitada pelo paciente ou por seu representante legal.

Art. 40. Aproveitar-se de situações decorrentes da relação médico-paciente para obter vantagem física, emocional, financeira ou de qualquer outra natureza.

Art. 41. Abreviar a vida do paciente, ainda que a pedido deste ou de seu representante legal.

Parágrafo único. Nos casos de doença incurável e terminal, deve o médico oferecer todos os cuidados paliativos disponíveis sem empreender ações diagnósticas ou terapêuticas inúteis ou obstinadas, levando sempre em consideração a vontade expressa do paciente ou, na sua impossibilidade, a de seu representante legal.

Art. 42. Desrespeitar o direito do paciente de decidir livremente sobre método contraceptivo, devendo sempre esclarecê-lo sobre indicação, segurança, reversibilidade e risco de cada método.

Capítulo VI

DOAÇÃO E TRANSPLANTE DE ÓRGÃOS E TECIDOS

É vedado ao médico:

Art. 43. Participar do processo de diagnóstico da morte ou da decisão de suspender meios artificiais para prolongar a vida do possível doador, quando pertencente à equipe de transplante. 
Art. 44. Deixar de esclarecer o doador, o receptor ou seus representantes legais sobre os riscos decorrentes de exames, intervenções cirúrgicas e outros procedimentos nos casos de transplantes de órgãos.

Art. 45. Retirar órgão de doador vivo quando este for juridicamente incapaz, mesmo se houver autorização de seu representante legal, exceto nos casos permitidos e regulamentados em lei.

Art. 46. Participar direta ou indiretamente da comercialização de órgãos ou de tecidos humanos.

\section{Capítulo VII}

\section{RELAÇÃO ENTRE MÉDICOS}

É vedado ao médico:

Art. 47. Usar de sua posição hierárquica para impedir, por motivo de crença religiosa, convicção filosófica, política, interesse econômico ou qualquer outro, que não técnico-científico ou ético, que as instalações e os demais recursos da instituição sob sua direção, sejam utilizados por outros médicos no exercício da profissão, particularmente se forem os únicos existentes no local.

Art. 48. Assumir emprego, cargo ou função para suceder médico demitido ou afastado em represália à atitude de defesa de movimentos legítimos da categoria ou da aplicação deste Código.

Art. 49. Assumir condutas contrárias a movimentos legítimos da categoria médica com a finalidade de obter vantagens.

Art. 50. Acobertar erro ou conduta antiética de médico.

Art. 51. Praticar concorrência desleal com outro médico.

Art. 52. Desrespeitar a prescrição ou o tratamento de paciente, determinados por outro médico, mesmo quando em função de chefia ou de auditoria, salvo em situação de indiscutível benefício para o paciente, devendo comunicar imediatamente o fato ao médico responsável. (VIDE RETIFICACÃo CONFORME DOU DE 13-102009)

Art. 53. Deixar de encaminhar o paciente que the foi enviado para procedimento especializado de volta ao médico assistente e, na ocasião, fornecer-lhe as devidas informações sobre o ocorrido no período em que por ele se responsabilizou.

Art. 54. Deixar de fornecer a outro médico informações sobre o quadro clínico de paciente, desde que autorizado por este ou por seu representante legal. 
Art. 55. Deixar de informar ao substituto o quadro clínico dos pacientes sob sua responsabilidade ao ser substituído ao fim do seu turno de trabalho.

Art. 56. Utilizar-se de sua posição hierárquica para impedir que seus subordinados atuem dentro dos princípios éticos.

Art. 57. Deixar de denunciar atos que contrariem os postulados éticos à comissão de ética da instituição em que exerce seu trabalho profissional e, se necessário, ao Conselho Regional de Medicina.

\section{Capítulo VIII}

\section{REMUNERAÇÃO PROFISSIONAL}

É vedado ao médico:

Art. 58. 0 exercício mercantilista da Medicina.

Art. 59. Oferecer ou aceitar remuneração ou vantagens por paciente encaminhado ou recebido, bem como por atendimentos não prestados.

Art. 60. Permitir a inclusão de nomes de profissionais que não participaram do ato médico para efeito de cobrança de honorários. (VIDE RETIFICACÁ̃o CONFORME DOU DE 13-10-2009)

Art. 61. Deixar de ajustar previamente com o paciente o custo estimado dos procedimentos.

Art. 62. Subordinar os honorários ao resultado do tratamento ou à cura do paciente.

Art. 63. Explorar o trabalho de outro médico, isoladamente ou em equipe, na condição de proprietário, sócio, dirigente ou gestor de empresas ou instituições prestadoras de serviços médicos.

Art. 64. Agenciar, aliciar ou desviar, por qualquer meio, para clínica particular ou instituições de qualquer natureza, paciente atendido pelo sistema público de saúde ou dele utilizar-se para a execução de procedimentos médicos em sua clínica privada, como forma de obter vantagens pessoais.

Art. 65. Cobrar honorários de paciente assistido em instituição que se destina à prestação de serviços públicos, ou receber remuneração de paciente como complemento de salário ou de honorários.

Art. 66. Praticar dupla cobrança por ato médico realizado.

Parágrafo único. A complementação de honorários em serviço privado pode ser cobrada quando prevista em contrato. 
Art. 67. Deixar de manter a integralidade do pagamento e permitir descontos ou retenção de honorários, salvo os previstos em lei, quando em função de direção ou de chefia.

Art. 68. Exercer a profissão com interação ou dependência de farmácia, indústria farmacêutica, óptica ou qualquer organização destinada à fabricação, manipulação, promoção ou comercialização de produtos de prescrição médica, qualquer que seja sua natureza.

Art. 69. Exercer simultaneamente a Medicina e a Farmácia ou obter vantagem pelo encaminhamento de procedimentos, pela comercialização de medicamentos, órteses, próteses ou implantes de qualquer natureza, cuja compra decorra de influência direta em virtude de sua atividade profissional.

Art. 70. Deixar de apresentar separadamente seus honorários quando outros profissionais participarem do atendimento ao paciente.

Art. 71. Oferecer seus serviços profissionais como prêmio, qualquer que seja sua natureza.

Art. 72. Estabelecer vínculo de qualquer natureza com empresas que anunciam ou comercializam planos de financiamento, cartões de descontos ou consórcios para procedimentos médicos.

Capítulo IX

SIGILO PROFISSIONAL

É vedado ao médico:

Art. 73. Revelar fato de que tenha conhecimento em virtude do exercício de sua profissão, salvo por motivo justo, dever legal ou consentimento, por escrito, do paciente.

Parágrafo único. Permanece essa proibição:

a) mesmo que o fato seja de conhecimento público ou o paciente tenha falecido;

b) quando de seu depoimento como testemunha. Nessa hipótese, o médico comparecerá perante a autoridade e declarará seu impedimento;

c) na investigação de suspeita de crime, o médico estará impedido de revelar segredo que possa expor o paciente a processo penal.

Art. 74. Revelar sigilo profissional relacionado a paciente menor de idade, inclusive a seus pais ou representantes legais, desde que o menor tenha capacidade de discernimento, salvo quando a não revelação possa acarretar dano ao paciente. 
Art. 75. Fazer referência a casos clínicos identificáveis, exibir pacientes ou seus retratos em anúncios profissionais ou na divulgação de assuntos médicos, em meios de comunicação em geral, mesmo com autorização do paciente.

Art. 76. Revelar informações confidenciais obtidas quando do exame médico de trabalhadores, inclusive por exigência dos dirigentes de empresas ou de instituições, salvo se o silêncio puser em risco a saúde dos empregados ou da comunidade.

Art. 77. Prestar informações a empresas seguradoras sobre as circunstâncias da morte do paciente sob seus cuidados, além das contidas na declaração de óbito, salvo por expresso consentimento do seu representante legal.

Art. 78. Deixar de orientar seus auxiliares e alunos a respeitar o sigilo profissional e zelar para que seja por eles mantido.

Art. 79. Deixar de guardar o sigilo profissional na cobrança de honorários por meio judicial ou extrajudicial.

\section{Capítulo X}

\section{DOCUMENTOS MÉDICOS}

É vedado ao médico:

Art. 80. Expedir documento médico sem ter praticado ato profissional que 0 justifique, que seja tendencioso ou que não corresponda à verdade.

Art. 81. Atestar como forma de obter vantagens.

Art. 82. Usar formulários de instituições públicas para prescrever ou atestar fatos verificados na clínica privada.

Art. 83. Atestar óbito quando não o tenha verificado pessoalmente, ou quando não tenha prestado assistência ao paciente, salvo, no último caso, se o fizer como plantonista, médico substituto ou em caso de necropsia e verificação médico-legal.

Art. 84. Deixar de atestar óbito de paciente ao qual vinha prestando assistência, exceto quando houver indícios de morte violenta.

Art. 85. Permitir o manuseio e o conhecimento dos prontuários por pessoas não obrigadas ao sigilo profissional quando sob sua responsabilidade.

Art. 86. Deixar de fornecer laudo médico ao paciente ou a seu representante legal quando aquele for encaminhado ou transferido para continuação do tratamento ou em caso de solicitação de alta.

Art. 87. Deixar de elaborar prontuário legível para cada paciente. 
$\S 1^{\circ} \mathrm{O}$ prontuário deve conter os dados clínicos necessários para a boa condução do caso, sendo preenchido, em cada avaliação, em ordem cronológica com data, hora, assinatura e número de registro do médico no Conselho Regional de Medicina.

$\S 2^{\circ} \mathrm{O}$ prontuário estará sob a guarda do médico ou da instituição que assiste o paciente.

Art. 88. Negar, ao paciente, acesso a seu prontuário, deixar de lhe fornecer cópia quando solicitada, bem como deixar de lhe dar explicações necessárias à sua compreensão, salvo quando ocasionarem riscos ao próprio paciente ou a terceiros.

Art. 89. Liberar cópias do prontuário sob sua guarda, salvo quando autorizado, por escrito, pelo paciente, para atender ordem judicial ou para a sua própria defesa.

$\S 1^{\circ}$ Quando requisitado judicialmente o prontuário será disponibilizado ao perito médico nomeado pelo juiz.

§ $2^{\circ}$ Quando o prontuário for apresentado em sua própria defesa, o médico deverá solicitar que seja observado o sigilo profissional.

Art. 90. Deixar de fornecer cópia do prontuário médico de seu paciente quando de sua requisição pelos Conselhos Regionais de Medicina. (vIDE RETIFICACÃ̃o CONFORME DOU DE 13-10-2009)

Art. 91. Deixar de atestar atos executados no exercício profissional, quando solicitado pelo paciente ou por seu representante legal.

Capítulo

XI

AUDITORIA E PERÍCIA MÉDICA

É vedado ao médico:

Art. 92. Assinar laudos periciais, auditoriais ou de verificação médico-legal quando não tenha realizado pessoalmente o exame. (VIDE RETIFICACÃO CONFORME DOU DE 13-10-2009)

Art. 93. Ser perito ou auditor do próprio paciente, de pessoa de sua família ou de qualquer outra com a qual tenha relações capazes de influir em seu trabalho ou de empresa em que atue ou tenha atuado.

Art. 94. Intervir, quando em função de auditor, assistente técnico ou perito, nos atos profissionais de outro médico, ou fazer qualquer apreciação em presença do examinado, reservando suas observações para o relatório.

Art. 95. Realizar exames médico-periciais de corpo de delito em seres humanos no interior de prédios ou de dependências de delegacias de polícia, unidades militares, casas de detenção e presídios. 
Art. 96. Receber remuneração ou gratificação por valores vinculados à glosa ou ao sucesso da causa, quando na função de perito ou de auditor.

Art. 97. Autorizar, vetar, bem como modificar, quando na função de auditor ou de perito, procedimentos propedêuticos ou terapêuticos instituídos, salvo, no último caso, em situações de urgência, emergência ou iminente perigo de morte do paciente, comunicando, por escrito, o fato ao médico assistente.

Art. 98. Deixar de atuar com absoluta isenção quando designado para servir como perito ou como auditor, bem como ultrapassar os limites de suas atribuições e de sua competência.

Parágrafo único. 0 médico tem direito a justa remuneração pela realização do exame pericial.

Capítulo XII

ENSINO E PESQUISA MÉDICA

É vedado ao médico:

Art. 99. Participar de qualquer tipo de experiência envolvendo seres humanos com fins bélicos, políticos, étnicos, eugênicos ou outros que atentem contra a dignidade humana.

Art. 100. Deixar de obter aprovação de protocolo para a realização de pesquisa em seres humanos, de acordo com a legislação vigente.

Art. 101. Deixar de obter do paciente ou de seu representante legal o termo de consentimento livre e esclarecido para a realização de pesquisa envolvendo seres humanos, após as devidas explicações sobre a natureza e as consequências da pesquisa.

Parágrafo único. No caso do sujeito de pesquisa ser menor de idade, além do consentimento de seu representante legal, é necessário seu assentimento livre e esclarecido na medida de sua compreensão.

Art. 102. Deixar de utilizar a terapêutica correta, quando seu uso estiver liberado no País.

Parágrafo único. A utilização de terapêutica experimental é permitida quando aceita pelos órgãos competentes e com o consentimento do paciente ou de seu representante legal, adequadamente esclarecidos da situação e das possíveis consequências.

Art. 103. Realizar pesquisa em uma comunidade sem antes informá-la e esclarecê-la sobre a natureza da investigação e deixar de atender ao objetivo de proteção à saúde pública, respeitadas as características locais e a legislação pertinente. 
Art. 104. Deixar de manter independência profissional e científica em relação a financiadores de pesquisa médica, satisfazendo interesse comercial ou obtendo vantagens pessoais.

Art. 105. Realizar pesquisa médica em sujeitos que sejam direta ou indiretamente dependentes ou subordinados ao pesquisador.

Art. 106. Manter vínculo de qualquer natureza com pesquisas médicas, envolvendo seres humanos, que usem placebo em seus experimentos, quando houver tratamento eficaz e efetivo para a doença pesquisada.

Art. 107. Publicar em seu nome trabalho científico do qual não tenha participado; atribuir-se autoria exclusiva de trabalho realizado por seus subordinados ou outros profissionais, mesmo quando executados sob sua orientação, bem como omitir do artigo científico o nome de quem dele tenha participado.

Art. 108. Utilizar dados, informações ou opiniões ainda não publicados, sem referência ao seu autor ou sem sua autorização por escrito.

Art. 109. Deixar de zelar, quando docente ou autor de publicações científicas, pela veracidade, clareza e imparcialidade das informações apresentadas, bem como deixar de declarar relações com a indústria de medicamentos, órteses, próteses, equipamentos, implantes de qualquer natureza e outras que possam configurar conflitos de interesses, ainda que em potencial.

Art. 110. Praticar a Medicina, no exercício da docência, sem o consentimento do paciente ou de seu representante legal, sem zelar por sua dignidade e privacidade ou discriminando aqueles que negarem o consentimento solicitado.

\section{Capítulo XIII \\ PUBLICIDADE MÉDICA \\ É vedado ao médico:}

Art. 111. Permitir que sua participação na divulgação de assuntos médicos, em qualquer meio de comunicação de massa, deixe de ter caráter exclusivamente de esclarecimento e educação da sociedade. (VIDE RETIFICACÃ̃o CONFORME DOU DE 13-10-2009)

Art. 112. Divulgar informação sobre assunto médico de forma sensacionalista, promocional ou de conteúdo inverídico.

Art. 113. Divulgar, fora do meio científico, processo de tratamento ou descoberta cujo valor ainda não esteja expressamente reconhecido cientificamente por órgão competente. 
Art. 114. Consultar, diagnosticar ou prescrever por qualquer meio de comunicação de massa.

Art. 115. Anunciar títulos científicos que não possa comprovar e especialidade ou área de atuação para a qual não esteja qualificado e registrado no Conselho Regional de Medicina.

Art. 116. Participar de anúncios de empresas comerciais qualquer que seja sua natureza, valendo-se de sua profissão.

Art. 117. Apresentar como originais quaisquer idéias, descobertas ou ilustrações que na realidade não o sejam.

Art. 118. Deixar de incluir, em anúncios profissionais de qualquer ordem, o seu número de inscrição no Conselho Regional de Medicina.

Parágrafo único. Nos anúncios de estabelecimentos de saúde devem constar o nome e o número de registro, no Conselho Regional de Medicina, do diretor técnico.

\section{Capítulo XIV \\ DISPOSIÇÕES GERAIS}

I - O médico portador de doença incapacitante para o exercício profissional, apurada pelo Conselho Regional de Medicina em procedimento administrativo com perícia médica, terá seu registro suspenso enquanto perdurar sua incapacidade.

II - Os médicos que cometerem faltas graves previstas neste Código e cuja continuidade do exercício profissional constitua risco de danos irreparáveis ao paciente ou à sociedade poderão ter o exercício profissional suspenso mediante procedimento administrativo específico.

III - O Conselho Federal de Medicina, ouvidos os Conselhos Regionais de Medicina e a categoria médica, promoverá a revisão e atualização do presente Código quando necessárias.

IV - As omissões deste Código serão sanadas pelo Conselho Federal de Medicina.

CONSELHO FEDERAL DE MEDICINA

Diário Oficial da União; Poder Executivo, Brasília, DF, 13 out. 2009. Seção I, p.173 - RETIFICAÇ̃̃O

\section{RETIFICAÇÕES}

Na Resolução CFM n ${ }^{\circ} 1.931$, de 17 de setembro de 2009, publicada no DOU de 24 de setembro de 2009, Seção 1, páginas 90-92, em seu anexo: 


\section{ONDE SE LÊ:}

PREÂMBULO

III - Para o exercício da Medicina, impõe-se a inscrição no Conselho Regional do respectivo estado, território ou Distrito Federal.

\section{LEIA-SE:}

PREÂMBULO

III - Para o exercício da Medicina impõe-se a inscrição no Conselho Regional do respectivo Estado, Território ou Distrito Federal.

\section{ONDE SE LÊ:}

PREÂMBULO

VI - Este Código de Ética Médica é composto de 25 princípios fundamentais do exercício da Medicina, 10 normas diceológicas, 118 normas deontológicas e cinco disposições gerais. A transgressão das normas deontológicas sujeitará os infratores às penas disciplinares previstas em lei.

\section{LEIA-SE:}

PREÂMBULO

VI - Este Código de Ética Médica é composto de 25 princípios fundamentais do exercício da Medicina, 10 normas diceológicas, 118 normas deontológicas e quatro disposições gerais. A transgressão das normas deontológicas sujeitará os infratores às penas disciplinares previstas em Lei.

\section{ONDE SE LÊ:}

\section{CAPITULO I}

PRINCÍPIOS FUNDAMENTAIS

XII - O médico empenhar-se-á pela melhor adequação do trabalho ao ser humano, pela eliminação e controle dos riscos à saúde inerentes às atividades laborais.

\section{LEIA-SE:}

CAPÍTULO I

PRINCÍPIOS FUNDAMENTAIS

XII - O médico empenhar-se-á pela melhor adequação do trabalho ao ser humano, pela eliminação e pelo controle dos riscos à saúde inerentes às atividades laborais.

\section{ONDE SE LÊ:}

\section{CAPÍTULO I}

\section{PRINCÍPIOS FUNDAMENTAIS}

XV - O médico será solidário com os movimentos de defesa da dignidade profissional, seja por remuneração digna e justa seja por condições de trabalho compatíveis com o exercício eticoprofissional da Medicina e seu aprimoramento técnico-científico.

\section{LEIA-SE:}

CAPÍTULO I

PRINCÍPIOS FUNDAMENTAIS

XV - O médico será solidário com os movimentos de defesa da dignidade profissional, seja por remuneração digna e justa, seja por condições de trabalho compatíveis com o exercício éticoprofissional da Medicina e seu aprimoramento técnico-científico.

\section{ONDE SE LÊ:}

Capítulo III RESPONSABILIDADE PROFISSIONAL

Art. 34. Deixar de informar ao paciente o diagnóstico, o prognóstico, os riscos e os objetivos do tratamento, salvo quando a comunicação direta possa provocar-lhe dano, devendo, nesse caso, fazer a comunicação a seu representante legal. 


\section{LEIA-SE:}

Capítulo III

RESPONSABILIDADE PROFISSIONAL

Art. 34. Deixar de informar ao paciente o diagnóstico, o prognóstico, os riscos e os objetivos do tratamento, salvo quando a comunicação direta possa lhe provocar dano, devendo, nesse caso, fazer a comunicação a seu representante legal.

ONDE SE LÊ:

Capítulo V

RELAÇÃO COM PACIENTES E FAMILIARES

Art. 37. Prescrever tratamento ou outros procedimentos sem exame direto do paciente, salvo em casos de urgência ou emergência e impossibilidade comprovada de realizá-lo, devendo, nesse caso, fazê-lo imediatamente após cessar o impedimento.

Parágrafo único. 0 atendimento médico a distância, nos moldes da telemedicina ou outro método, dar-se-á sob regulamentação do Conselho Federal de Medicina.

\section{LEIA-SE:}

Capítulo $V$

RELAÇÃO COM PACIENTES E FAMILIARES

Art. 37. Prescrever tratamento ou outros procedimentos sem exame direto do paciente, salvo em casos de urgência ou emergência. e impossibilidade comprovada de realizá-lo, devendo, nesse caso, fazê-lo imediatamente após cessar o impedimento.

Parágrafo único. $O$ atendimento médico a distância, nos moldes da telemedicina ou de outro método, dar-se-á sob regulamentação do Conselho Federal de Medicina.

\section{ONDE SE LÊ:}

Capítulo VII

RELAÇÃO ENTRE MÉDICOS

Art. 52. Desrespeitar a prescrição ou o tratamento de paciente, determinado por outro médico, mesmo quando em função de chefia ou de auditoria, salvo em situação de indiscutível benefício para o paciente, devendo comunicar imediatamente o fato ao médico responsável.

\section{LEIA-SE:}

Capítulo VII

RELAÇÃO ENTRE MÉDICOS

Art. 52. Desrespeitar a prescrição ou o tratamento de paciente, determinados por outro médico, mesmo quando em função de chefia ou de auditoria, salvo em situação de indiscutível benefício para o paciente, devendo comunicar imediatamente o fato ao médico responsável.

\section{ONDE SE LÊ:}

Capítulo VII

RELAÇÃO ENTRE MÉDICOS

Art. 60. Permitir a inclusão de nomes de profissionais que não participaram do ato médico, para efeito de cobrança de honorários.

\section{LEIA-SE:}

Capítulo VII

RELAÇÃO ENTRE MÉDICOS

Art. 60. Permitir a inclusão de nomes de profissionais que não participaram do ato médico para efeito de cobrança de honorários.

\section{ONDE SE LÊ:}

Capítulo VII

RELAÇÃO ENTRE MÉDICOS

Art. 90. Deixar de fornecer cópia do prontuário médico de seu paciente quando requisitado pelos Conselhos Regionais de Medicina. 


\section{LEIA-SE:}

Capítulo VII

RELAÇÃO ENTRE MÉDICOS

Art. 90. Deixar de fornecer cópia do prontuário médico de seu paciente quando de sua requisição pelos Conselhos Regionais de Medicina.

\section{ONDE SE LÊ:}

Capítulo XI

AUDITORIA E PERÍCIA MÉDICA

É vedado ao médico:

Art. 92. Assinar laudos periciais, auditoriais ou de verificação médico-legal, quando não tenha realizado pessoalmente o exame.

\section{LEIA-SE:}

Capítulo XI

AUDITORIA E PERÍCIA MÉDICA

É vedado ao médico:

Art. 92. Assinar laudos periciais, auditoriais ou de verificação médico-legal quando não tenha realizado pessoalmente o exame.

\section{ONDE SE LÊ:}

Capítulo XIII

PUBLICIDADE MÉDICA

Art. 111. Permitir que sua participação na divulgação de assuntos médicos, em qualquer meio de comunicação de massa, deixe de ter caráter exclusivamente de esclarecimento e educação da sociedade.

\section{LEIA-SE:}

Capítulo XIII

PUBLICIDADE MÉDICA

É vedado ao médico:

Art. 111. Permitir que sua participação na divulgação de assuntos médicos, em qualquer meio de comunicação de massa, deixe de ter caráter exclusivamente de esclarecimento e educação da sociedade 
MINISTÉRIO DA SAÚDE

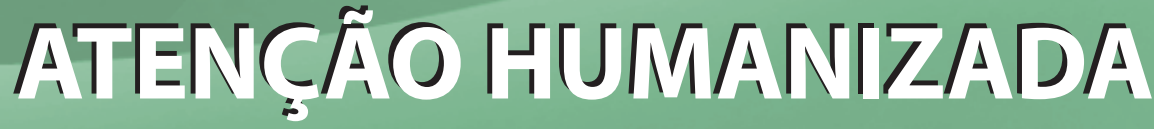 AO A BORTAAMIENTTO
}

\author{
Norma Técnica
}




\section{ATENÇÃO HUMANIZADA AO ABORTAMENTO}

\section{Norma Técnica}

$2^{\mathrm{a}}$ edição

Série A. Normas e Manuais Técnicos

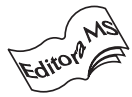

BRASÍLIA - DF 
(c) 2005 Ministério da Saúde.

Todos os direitos reservados. É permitida a reprodução parcial ou total desta obra, desde que citada a fonte e que não seja para venda ou qualquer fim comercial.

A responsabilidade pelos direitos autorais de textos e imagens desta obra é da área técnica.

A coleção institucional do Ministério da Saúde pode ser acessada, na íntegra, na Biblioteca Virtual em Saúde do Ministério da Saúde: http://www.saude.gov.br/bvs

O conteúdo desta e de outras obras do Ministério da Saúde pode ser acessado na página:

http://www.saude.gov.br/editora

Tiragem: 2a edição - 2011 - 149.536 exemplares

Série Direitos Sexuais e Direitos Reprodutivos - Caderno n 4

Edição, distribuição e informações:

MINISTÉRIO DA SAÚDE

Secretaria de Atenção à Saúde

Departamento de Ações Programáticas Estratégicas

Área Técnica de Saúde da Mulher

SAF, Trecho 2, Lote 5/6, Ed. Premium

Torre II, Sala 17, Térreo. CEP: 70070-600

Tel.: 61-3306-8101

E-mail: www.saude.mulher@saude.gov.br

Elaboração $1^{a}$ Edição:

Adson França

Aníbal Faundes

Cristião Fernando Rosas

Estela Aquino

Gilberta Soares

Greice Menezes

Jorge Andalaft Neto

Leila Adesse

Maria José de Oliveira Araújo

Rivaldo Mendes de Albuquerque

Colaboração $1^{a}$ Edição:

Eleonora Menecucci de Oliveira

Fátima Oliveira

Jacira Melo

Jefferson Drezett Ferreira

José Henrique Torres

Juliana Monti Maifrino

Miriam Ventura

Secretaria Especial de Políticas para as Mulheres

Valéria Pandjiarjian

Elaboração 2a Edição:

Ministério da Saúde

Secretaria de Atenção à Saúde

Departamento de Ações Programáticas Estratégicas

Área Técnica de Saúde da Mulher

Comissão de Violência Sexual e Aborto Previsto em Lei da Febrasgo

Colaboração 2a Edição:

Avelar de Holanda Barbosa

Cláudia Araújo de Lima

Daniela Gontijo

Jefferson Drezett Ferreira

José Henrique Torres

Liliane Brum Ribeiro

Osmar Ribeiro Colas

Editora MS

Coordenação de Gestão Editorial

SIA, trecho 4, lotes 540/610

CEP: 71200-040, Brasília - DF

Tels.: (61) 3233-1774 / 2020

Fax: (61) 3233-9558

E-mail: editora.ms@saude.gov.br

Home page: http://www.saude.gov.br/editora

Equipe editorial:

Normalização: Adenilson Félix

Revisão: Khamila Silva e Mara Soares Pamplona

Capa, projeto gráfico e diagramação: Marcelo Rodrigues

Impresso no Brasil / Printed in Brazil

Ficha Catalográfica

Brasil. Ministério da Saúde. Secretaria de Atenção à Saúde. Departamento de Ações Programáticas Estratégicas.

Atenção humanizada ao abortamento: norma técnica / Ministério da Saúde, Secretaria de Atenção à Saúde, Área

Técnica de Saúde da Mulher. - 2. ed. - Brasília : Ministério da Saúde, 2011.

60 p. - (Série A. Normas e Manuais Técnicos) (Série Direitos Sexuais e Direitos Reprodutivos ; Caderno n 4)

ISBN 978-85-334-1711-3

1. Saúde da Mulher 2. Abortamento 3. Atenção Humanizada 4. Normas Técnicas I. Brasil. Ministério da Saúde. II. Brasil. Secretaria de Atenção à Saúde. Área Técnica de Saúde da Mulher. III. Título. IV. Séries.

CDU 618.39

Catalogação na fonte - Coordenação-Geral de Documentação e Informação - Ministério da Saúde - OS 2011/0185

Títulos para indexação:

Em inglês: Humanized attention to the abortin: technical rule

Em espanhol: Atención humanizada al aborto: norma técnica 


\section{SUMÁRIO}

APRESENTAÇÃO. 5

INTRODUÇÃO

1 MARCO CONCEITUAL DE ATENÇÃO AO ABORTAMENTO 13

2 ASPECTOS ÉTICO-PROFISSIONAIS E JURÍDICOS DO ABORTAMENTO.. 15

2.1 PLANO INTERNACIONAL ...................................................................................15

2.2 PLANO NACIONAL ........................................................................................

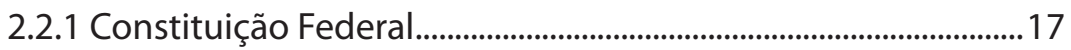

2.2.2 Código Penal, Doutrina e Jurisprudência .......................................17

2.2.3 Norma Técnica de Prevenção e Tratamento

dos Agravos Resultantes da Violência Sexual Contra

Mulheres e Adolescentes ................................................................................ 18

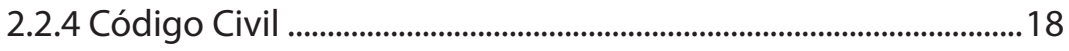

2.2.5 Ética profissional................................................................................. 19

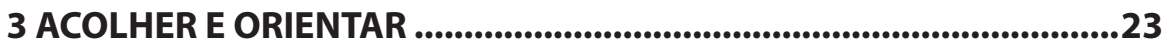

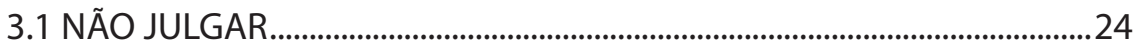

3.2 ACOLHIMENTO É TAREFA DA EQUIPE DE SAÚDE.....................................24

3.3 ROTEIRO DE CONVERSA ............................................................................2

3.3.1 Mudança de postura .............................................................................25

3.3.2 Atenção humanizada ..........................................................................25

3.4 ESCUTA QUALIFICADA …………………………………………………....2

3.4.1 É responsabilidade da equipe ...........................................................2

3.4.2 Para os profissionais de saúde mental e serviço social.............27

3.4.3 Informar e orientar.................................................................................2 
3.4.4 Orientações clínicas.................................................................................28

3.4.5 Orientações gerais .........................................................................28

\section{ATENÇÃO CLÍNICA AO ABORTAMENTO ............................................29}

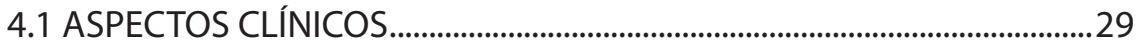

4.1.1 Ameaça de abortamento...............................................................29

4.1.2 Abortamento completo .........................................................................30

4.1.3 Abortamento inevitável/incompleto .................................................30

4.1.4 Abortamento retido .........................................................................

4.1.5 Abortamento infectado ..................................................................31

4.1.6 Abortamento habitual...................................................................32

4.1.7 Abortamento eletivo previsto em lei ...............................................33

4.2 ESCOLHENDO AS TÉCNICAS DE ESVAZIAMENTO UTERINO .................33

4.2.1 Abortamento farmacológico ..............................................................34

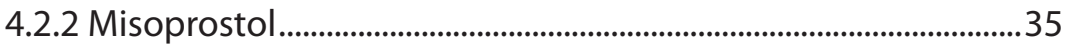

4.2.2 Aspiração Manual Intrauterina (Amiu)...........................................37

4.2.3 Curetagem uterina..............................................................................38

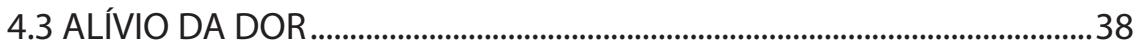

5 PLANEJAMENTO REPRODUTIVO PÓS-ABORTAMENTO .................41

5.1 ORIENTAÇÃO EM PLANEJAMENTO REPRODUTIVO ..................................41

5.2 OFERTA DE MÉTODOS ANTICONCEPCIONAIS ..........................................42

5.3 ABORTAMENTO ESPONTÂNEO E ORIENTAÇÃO CONCEPCIONAL.....43

REFERÊNCIAS ............................................................................45

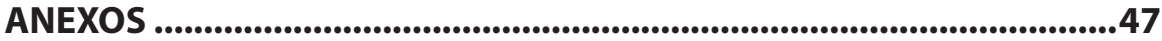

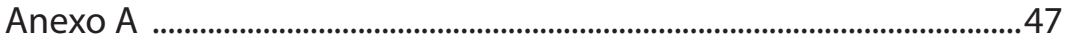

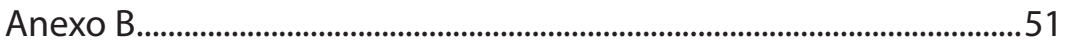

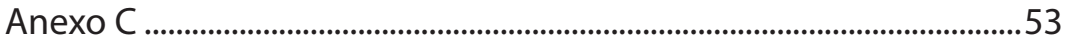

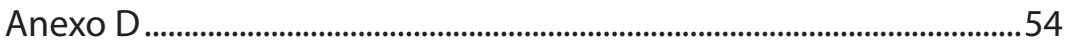

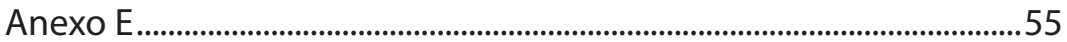

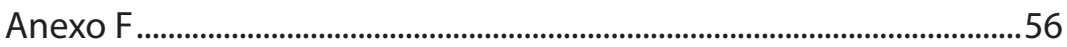

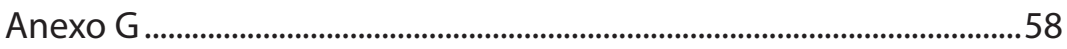




\section{APRESENTAÇÃO}

O abortamento representa um grave problema de saúde pública. Estima-se que ocorram, considerando apenas o Brasil, mais de um miIhão de abortamentos induzidos ao ano, sendo uma das principais causas de morte materna no País. Por atravessar um emaranhado de aspectos sociais, culturais, econômicos, jurídicos, religiosos e ideológicos, é tema que incita passionalidade e dissensão, parecendo, sob consideráveis perspectivas, distante de saída. Compreender sua abrangência e (re)pensar soluções demanda tanto investimento em educação e informação - vitais no aprimoramento da capacidade crítica - quanto o comprometimento constante do Estado, dos profissionais de saúde e da sociedade em geral com o ordenamento jurídico nacional e alguns de seus mais basilares princípios: a democracia, a laicidade do Estado, a igualdade de gênero e a dignidade da pessoa humana.

O Ministério da Saúde, atento à primazia dos direitos humanos e sensível às reivindicações dos movimentos feministas e de mulheres, que não arrefecem na luta histórica por tais direitos, ganhou, nos últimos anos, visível e inexorável fôlego no compromisso com a garantia dos direitos reprodutivos e dos direitos sexuais das mulheres. Vem pautando-se, para tanto, pelo zelo no seguimento dos acordos internacionais dos quais o Brasil é signatário e pela legislação nacional vigente, com destaque para a consolidação de garantias constitucionais e pela recente Lei Maria da Penha. Esta última, sendo marco político essencial no enfrentamento não somente à violência doméstica em geral, mas também ao estupro ocorrido em âmbito doméstico, que não raro provoca gestações incestuosas, produzindo traumas indeléveis em crianças e adolescentes.

Em 20 anos do Sistema Único de Saúde e 25 anos de criação PAISM, tendo os Objetivos de Desenvolvimento do Milênio (ODM) como horizonte, o Ministério da Saúde, por meio da Área Técnica de Saúde da Mulher, apresenta aos profissionais de saúde a nova edição da Norma Técnica de Atenção Humanizada ao Abortamento, com revisão de normas gerais de acolhimento, orientação e atenção clínica. Cumpre, assim, esta nova edição, objetivos específicos da Política Nacional de Atenção Integral 
à Saúde da Mulher - e seus Planos de Ação, ao buscar promover a atenção qualificada e humanizada - obstétrica e neonatal, incluindo a assistência ao abortamento em condições inseguras, para mulheres e adolescentes.

Ademais, o Ministério da Saúde vem atuando, de maneira intra e intersetorial, no âmbito do Pacto Nacional pela Redução da Mortalidade Materna e Neonatal e, em especial, de forma articulada com a Secretaria Especial de Políticas para as Mulheres (SPM), nos Planos Nacionais de Políticas para as Mulheres. Caminha, desse modo, para a ampliação do acesso à atenção, auxiliando profissionais de saúde na organização de serviços e no desenvolvimento de uma atuação eficaz, qualificada e livre de julgamentos morais nos casos de abortamento, base de uma saúde pública de fato universal, integral e equânime.

Área Técnica de Saúde da Mulher

Ministério da Saúde 


\section{INTRODUÇÃO}

O abortamento representa um grave problema de saúde pública, com maior incidência em países em desenvolvimento, sendo uma das principais causas de mortalidade materna no mundo, inclusive no Brasil. Sua discussão, notadamente passional em muitos países, envolve uma intricada teia de aspectos legais, morais, religiosos, sociais e culturais. Vulnerabilidades como desigualdade de gênero, normas culturais e religiosas, desigualdade de acesso à educação, e múltiplas dimensões da pobreza - com a falta de recursos econômicos e de alternativas, a dificuldade de acesso a informação e direitos humanos, a insalubridade, dentre outros fazem com que o abortamento inseguro atinja e sacrifique, de forma mais devastadora, mulheres de comunidades pobres e marginalizadas.

O abortamento espontâneo ocorre em aproximadamente (10 a $15 \%)$ das gestações e envolve sensações de perda, culpa pela impossibilidade de levar a gestação a termo, além de trazer complicações para o sistema reprodutivo, requerendo uma atenção técnica adequada, segura e humanizada. Outros $10 \%$ dos abortamentos atendidos em nossos hospitais são provocados pelas mais diferentes formas, já que, para um grande contingente de mulheres, o abortamento resulta de necessidades não satisfeitas de planejamento reprodutivo, envolvendo a falta de informação sobre anticoncepção, dificuldades de acesso aos métodos, falhas no seu uso, uso irregular ou inadequado, e/ou ausência de acompanhamento pelos serviços de saúde. É preciso destacar que, para muitas mulheres, a gestação que motiva o abortamento resulta de violência sexual, seja por desconhecido, seja cometida pelo parceiro ou outro membro em âmbito doméstico e/ou intrafamiliar.

Aspectos culturais, religiosos, legais e morais inibem as mulheres a declararem seus abortamentos, dificultando o cálculo da sua magnitude. Independente dessa dificuldade, sabe-se que o abortamento é praticado com o uso de meios diversos, muitas vezes induzidos pela própria mulher ou realizados em condições inseguras, em geral acarretando consequências danosas à saúde, podendo, inclusive, levar à morte. O informe de outubro de 2008, do Instituto Guttmacher, aponta como métodos usuais em 
abortamentos inseguros a inserção de preparos herbais na vagina, chás, saltos de escadas ou telhados, o uso de paus, ossos de frango, dentre outros objetos de risco.

Segundo estimativas da Organização Mundial da Saúde, metade das gestações é indesejada, com uma a cada nove mulheres recorrendo ao abortamento para interrompê-las. De acordo com dados recentes do Instituto Guttmacher de Washington, D.C. - EUA, o número de abortos induzidos no mundo caiu de 45,6, em 1995, para 41,6 milhões, em 2003. A queda nos índices foi mais drástica em países desenvolvidos, caindo de 10 milhões, em 1995, para 6,6 milhões em 2003. Na Europa, o número caiu de 7,7 milhões para 4,3 milhões. A queda mais acentuada se deu no leste europeu, onde o aborto já é seguro e descriminalizado, na maioria dos países. Houve decréscimo de 90 para 44 na proporção de abortamentos a cada 1.000 mulheres entre 15 e 44 anos (THE ALAN GUTTMACHER INSTITUTE, 2008).

Por outro lado, considerando o mesmo intervalo de 1995 a 2003, para os países em desenvolvimento, não houve queda expressiva, sendo de 35,5 milhões em 1995 para 35 milhões em 2003. Excluindo desta contagem a China, percebe-se, em números absolutos, um aumento de 24.9 milhões para 26.4 milhões. Na América Latina, houve queda, também inexpressiva, de 4,2 milhões em 1995 para 4,1 milhões em 2003 (AGI, 2008).

No Brasil, estima-se a ocorrência de mais de um milhão de abortos inseguros ao ano. O artigo 128 do Código Penal de 1940 prevê o abortamento legalizado para gestações resultantes de estupro e para o caso de risco de morte para a mulher, a questão está em cumprir a legislação.

Os avanços já alcançados, ainda insuficientes, apontam o crescimento do número de serviços de referência para o atendimento ao abortamento previsto em lei e mobilização - com a implementação das Redes de Atenção Integral à Saúde de Mulheres e Adolescentes em Situação de Violência Doméstica e/ou Sexual - articulada e organizada por estados, municípios e o Governo Federal para a criação de outros. O Judiciário tem autorizado, com frequência, o abortamento para os casos de má-formação fetal incompatível com a vida e o Supremo Tribunal Federal vem estudando a interrupção da gestação nesses casos. 
Em países onde as mulheres têm acesso aos serviços seguros, suas probabilidades de morrer em decorrência de um abortamento realizado com métodos modernos não é maior do que uma para cada 100 mil procedimentos (AGl, 1999). Em países em desenvolvimento, o risco de morte por complicações de procedimentos de abortamento inseguro é várias vezes mais alto do que de um abortamento realizado por profissionais e em condições seguras (ORGANIZAÇÃO MUNDIAL DA SAÚDE, 2004). Por outro lado, em países onde o aborto é proibido por lei ou norma religiosa, não há queda da taxa total de abortos, pelo contrário, estudos demonstram um efeito direto entre a proibição e o aumento das taxas de abortamentos clandestinos e inseguros, e logo, da mortalidade materna (AGI, 2004, 2008; BRASIL, 2006; DREZETT, 2005)

O abortamento representa uma das principais causas de mortalidade materna no Brasil. Segundo estudo da Mortalidade de Mulheres, de 10 a 49 anos, com Pesquisa realizada em 2002, em todas as capitais e no Distrito Federal, evidenciou a permanência de alta taxa de mortalidade materna no País (BRASIL, 2006), diferentemente do que ocorre em países desenvolvidos, onde essas taxas de morte, especificamente por aborto, são reduzidas. Entre 1995 e 2000, estatísticas de vários países europeus mostram taxas inferiores a 10 óbitos/100.000 nascidos vivos, com o aborto sendo realizado em condições seguras, não se constituindo mais importante causa de óbito, (ALEXANDER et al., 2003).

A despeito da subnotificação dos óbitos por aborto, tem sido observada, nas últimas décadas, uma tendência de declínio da taxa de mortalidade por essa causa no Brasil. Entretanto, verifica-se não somente um decréscimo da média de idade das mulheres que foram a óbito, como também a permanência de desigualdades regionais, com menor redução dessas taxas nos estados nordestinos. É também nesta região do País onde as mortes decorrentes do abortamento inseguro adquirem mais importância entre as causas de morte materna. Em municípios da Região Metropolitana do Recife, incluindo a capital, entre 1994 e 1996, o aborto ocupou, respectivamente, o primeiro e segundo lugar deste grupo de causas, decrescendo nos anos seguintes (VALONGUEIRO, 1996; RECIFE, 1998) e, em Salvador, desde o início da década de 90, o abortamento 
permanece como a primeira causa isolada de morte materna, com adolescentes e jovens apresentando maiores riscos de morte (COMPTE, 1995; MENEZES; AQUINO, 2001).

Considerando que a mortalidade representa apenas uma fração dessa problemática, os dados referentes à hospitalização por abortamento confirmam sua magnitude. A curetagem pós-abortamento representa o terceiro procedimento obstétrico mais realizado nas unidades de internação da rede pública de serviços de saúde.

As repercussões sociais na vida pessoal, familiar, e no mundo do trabalho precisam ser analisadas e respeitadas, na medida em que o abortamento atinge mulheres jovens, em plena idade produtiva e reprodutiva, levando-as desnecessariamente à morte ou implicando sequelas à sua saúde física, mental e reprodutiva. Complicações físicas imediatas, como hemorragias, infecções, perfurações de órgãos e infertilidade se somam aos transtornos subjetivos, ao se vivenciar o ônus de uma escolha inegavelmente difícil num contexto de culpabilização e de penalização do abortamento.

No Brasil, sua prática se traduz numa inequívoca expressão das desigualdades sociais, pois embora compartilhem a mesma situação ante a ilegalidade da intervenção, as mulheres percorrem distintas trajetórias, com uma minoria delas podendo arcar com os custos de um abortamento rápido, seguro e sem riscos. A maior parcela da população feminina recorre a várias estratégias inseguras que frequentemente se complicam e acarretam mortes maternas por abortamento. Para a redução da mortalidade materna, o SUS trabalha para melhorar a saúde das gestantes, a promoção da igualdade entre os sexos e a valorização das mulheres, ou seja, alcançar as metas números três e cinco dos Objetivos de Desenvolvimento do Milênio que estão interligadas.

A necessidade de uma atenção oportuna é imperiosa, dada a dificuldade das mulheres em reconhecer sinais de possíveis complicações, aliado ao fato de que o medo e a vergonha são fatores que podem retardar a busca de cuidado. Não menos importante que esses aspectos, se faz necessário superar a discriminação e a desumanização do atendimento 
às mulheres em situação de abortamento, ainda uma realidade de muitos serviços públicos no País. São expressões disso não só a recusa da internação em certos hospitais ou a longa espera para atendimento, como também a demora na resposta às demandas das mulheres, seja por desqualificação dos sintomas, seja por tomá-los como expressão de um suposto sentimento de culpa por terem provocado o aborto.

Esta Norma pretende, portanto, fornecer aos profissionais subsídios para que possam oferecer não só um cuidado imediato às mulheres em situação de abortamento, mas também, na perspectiva da integralidade deste atendimento, disponibilizá-las alternativas contraceptivas, evitando o recurso a abortos repetidos. Para mulheres com abortamentos espontâneos e que desejem nova gestação deve ser garantido um atendimento adequado às suas necessidades.

É fundamental, por fim, reconhecer que a qualidade da atenção almejada inclui aspectos relativos à sua humanização, incitando profissionais, independentemente dos seus preceitos morais e religiosos, a preservarem uma postura ética, garantindo o respeito aos direitos humanos das mulheres. 



\section{MARCO CONCEITUAL DE ATENÇÃO AO ABORTAMENTO}

A inclusão de um modelo humanizado de atenção às mulheres com abortamento é propósito desta Norma. Isso não apenas como um guia de cuidados, mas também na intenção de oferecer às mulheres, aos serviços de saúde e à sociedade um novo paradigma que torne seguro, sustentável e efetivo a atenção às mulheres em situação de abortamento. Para que esse modelo possa ser implantado faz-se necessária a inclusão dos seguintes elementos essenciais:

1. Rede integrada com a comunidade e com os prestadores de serviço para a prevenção das gestações indesejadas e do abortamento inseguro, para a mobilização de recursos e para a garantia de que os serviços reflitam as necessidades da comunidade e satisfaçam suas expectativas.

2. Acolhimento e orientação para responder às necessidades de saúde mental e física das mulheres, além de outras preocupações que possam surgir.

3. Atenção clínica adequada ao abortamento e suas complicações, segundo referenciais éticos, legais e bioéticos.

4. Oferecimento de serviços de planejamento reprodutivo às mulheres pós-abortamento, inclusive orientações para aquelas que desejam nova gestação.

5. Integração com outros serviços de atenção integral à saúde e de inclusão social para as mulheres. 



\section{ASPECTOS ÉTICO-PROFISSIONAIS E JURÍDICOS DO ABORTAMENTO}

A atenção humanizada às mulheres em abortamento merece abordagem ética e reflexão sobre os aspectos jurídicos, tendo como princípios norteadores a igualdade, a liberdade e a dignidade da pessoa humana, não se admitindo qualquer discriminação ou restrição ao acesso à assistência à saúde. Esses princípios incorporam o direito à assistência ao abortamento no marco ético e jurídico dos direitos sexuais e reprodutivos afirmados nos planos internacional e nacional de direitos humanos.

\subsection{PLANO INTERNACIONAL}

As Conferências das Nações Unidas reconhecem tais direitos, especialmente no campo da saúde e da autodeterminação sexual e reprodutiva.

Conferência Mundial sobre Direitos Humanos, Viena (1993): os direitos das mulheres e meninas são parte inalienável, integral e indivisível dos direitos humanos universais, e a violência de gênero, inclusive a gravidez forçada, é incompatível com a dignidade e o valor da pessoa humana.

Conferência Internacional sobre População e Desenvolvimento, Cairo (1994) e Conferência Mundial sobre a Mulher, Beijing (1995): os direitos reprodutivos são constituídos por direitos humanos reconhecidos nos diversos tratados e convenções internacionais e incluem o direito de toda pessoa a ter controle e decisão sobre as questões relativas à sua sexualidade e reprodução, livres de coerção, discriminação e violência, e de dispor de informações e meios adequados que lhes garantam o mais elevado padrão de saúde sexual e saúde reprodutiva; o tema do aborto inseguro deve ser tratado de forma humana e solidária.

Cairo e Beijing definem como saúde reprodutiva: "um estado de completo bem-estar físico, mental e social, e não de mera ausência de enfermidade ou doença, em todos os aspectos relacionados com o sistema reprodutivo e suas funções e processos". (Fonte: item 7.2, Cairo; parágrafo 94, Beijing). 
A saúde reprodutiva inclui o direito de mulheres e homens:

a) a desfrutar de uma vida sexual satisfatória e sem risco;

b) a procriar, com liberdade para decidir fazê-lo ou não, quando e com que frequência;

c) à informação e ao acesso a métodos seguros, eficientes e exequíveis de planejamento familiar de sua escolha;

d) ao acesso a serviços de acompanhamento na gravidez e no parto sem riscos, garantindo-Ihes as melhores possibilidades de terem fiIhos sãos.

Pela magnitude dos efeitos dos abortamentos realizados em condições inadequadas sobre a saúde da mulher, os governos foram instados a desenvolver ações para tratá-los, a considerar o abortamento como um importante problema de saúde pública, e reduzir sua prática mediante a prestação de serviços de planejamento familiar (Parágrafo 8.25, Cairo), bem como, "considerar a possibilidade de reformar as leis que preveem medidas punitivas contra as mulheres que tenham sido submetidas a abortos ilegais" (parágrafo 106 k, Beijing).

Ainda, "em circunstâncias em que o aborto não é contra a lei, o sistema de saúde deve treinar e equipar os provedores de serviços de saúde e deve tomar outras medidas para assegurar-se de que tais abortos sejam seguros e acessíveis". (Cairo +5, artigo 63, inciso 3).

O Brasil é signatário dos documentos dessas conferências e de tratados internacionais de direitos humanos, com destaque para a Convenção sobre a Eliminação de Todas as Formas de Discriminação contra a Mulher (ONU, 1979) e para a Convenção Interamericana para Prevenir, Punir e Erradicar a Violência contra a Mulher (OEA, 1994). 
A prevenção da gravidez não desejada, do abortamento e de suas consequências são de alta prioridade para profissionais de saúde. Às muIheres deve ser garantindo o acesso: à informação e orientação humana e solidária; ao abortamento previsto em lei; à atenção de qualidade em complicações derivadas de abortos; e ao planejamento reprodutivo pós-aborto para, inclusive, evitar abortos repetidos.

\subsection{PLANO NACIONAL}

A legislação brasileira incorpora os direitos humanos internacionais e prevê princípios e normas éticas e jurídicas relacionadas à prevenção da gestação indesejada e ao abortamento.

São elas:

\subsubsection{Constituição Federal}

Igualdade: "homens e mulheres são iguais em direitos e obrigações" (Art. 5, I), inclusive no que se refere à "sociedade conjugal" (Art. 226, § 3).

Planejamento familiar: "fundado no princípio da dignidade da pessoa humana e da paternidade responsável, o planejamento familiar é livre decisão do casal, competindo ao Estado propiciar recursos educacionais e científicos para o exercício desse direito, vedada qualquer forma coercitiva por parte de instituições oficiais ou privadas" (Art. 226, § 70). A Lei n 9.263/96 o define como o conjunto de ações de regulação da fecundidade que garanta direitos iguais de constituição, limitação ou aumento da prole pela mulher, homem ou casal.

\subsubsection{Código Penal, Doutrina e Jurisprudência}

Não é crime e não se pune: o abortamento praticado por médico(a), se: a) não há outro meio de salvar a vida da mulher (Art. 128, I); b) a gravidez é resultante de estupro (ou outra forma de violência sexual), com o consentimento da mulher ou, se incapaz, de seu representante legal (Art. 128, II). 
A jurisprudência brasileira tem autorizado a interrupção de gravidez nos casos de malformação fetal com inviabilidade de vida extrauterina, com o consentimento da mulher. Nesses casos, o abortamento é um direito da mulher.

2.2.3 Norma Técnica de Prevenção e Tratamento dos Agravos Resultantes da Violência Sexual Contra Mulheres e Adolescentes

O Ministério da Saúde normatizou os procedimentos para o atendimento ao abortamento em gravidez por violência sexual, conforme Norma Técnica de Prevenção e Tratamento dos Agravos Resultantes de Violência Sexual contra as Mulheres e Adolescentes, que contempla a organização da atenção e um guia geral para esse atendimento. O Código Penal não exige qualquer documento para a prática do abortamento nesses casos, e a mulher violentada sexualmente não tem o dever legal de noticiar o fato à polícia. Deve-se orientá-la a tomar as providências policiais e judiciais cabíveis, mas caso ela não o faça, não lhe pode ser negado o abortamento.

O(a) médico(a) e demais profissionais de saúde não devem temer possíveis consequências jurídicas, caso revele-se posteriormente que a gravidez não foi resultado de violência sexual, pois "é isento de pena quem, por erro plenamente justificado pelas circunstâncias, supõe situação de fato que, se existisse, tornaria a ação legítima" (Código Penal, Art. 20, § 1).

\subsubsection{Código Civil}

Do consentimento

O consentimento da mulher é necessário para o abortamento em quaisquer circunstâncias, salvo em caso de eminente risco de vida estando a mulher impossibilitada para expressar seu consentimento. De

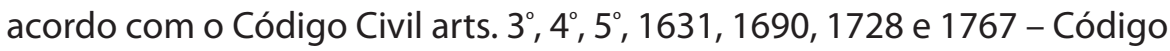
Civil:

a) a partir dos 18 anos: a mulher é capaz de consentir sozinha; 
b) a partir dos 16 e antes dos 18 anos: a adolescente deve ser assistida pelos pais ou por seu representante legal, que se manifestam com ela;

c) antes de completar 16 anos: a adolescente ou criança deve ser representada pelos pais ou por seu representante legal, que se manifestam por ela.

A outra circunstância em que é necessário o consentimento de representante legal (curador/a ou tutor/a) refere-se à mulher que, por qualquer razão, não tenha condições de discernimento e de expressão de sua vontade.

De qualquer forma, sempre que a mulher ou adolescente tiver condições de discernimento e de expressão de sua vontade, deverá também consentir, assim como deverá ser respeitada a sua vontade se não consentir com o abortamento, que não deverá ser praticado, ainda que os seus representantes legais assim o queiram.

\subsection{5 Ética Profissional}

Do sigilo profissional

Diante de abortamento espontâneo ou provocado, o(a) médico(a) ou qualquer profissional de saúde não pode comunicar o fato à autoridade policial, judicial, nem ao Ministério Público, pois o sigilo na prática profissional da assistência à saúde é um dever legal e ético, salvo para proteção da usuária e com o seu consentimento. O não cumprimento da norma legal pode ensejar procedimento criminal, civil e ético-profissional contra quem revelou a informação, respondendo por todos os danos causados à mulher.

É crime: "revelar alguém, sem justa causa, segredo de que tem ciência em razão de função, ministério, ofício ou profissão, e cuja revelação possa produzir dano a outrem" (Código Penal, art. 154).

Constituição Federal: "são invioláveis a intimidade, a vida privada, a honra e a imagem das pessoas, assegurado o direito à indenização material ou moral decorrente de sua violação" (Art. 5, X). 
Quanto à criança e ao adolescente

Código de Ética Médica: "é vedado ao médico revelar segredo profissional referente à paciente menor de idade, inclusive a seus pais ou responsáveis legais, desde que o menor tenha capacidade de avaliar seu problema e de conduzir-se por seus próprios meios para solucioná-los, salvo quando a não revelação possa acarretar danos ao paciente" (Artigo 74 - Resolução CFM n 1.931, de 17 de setembro de 2009 - Código de Ética Médica).

Estatuto da Criança e do Adolescente: a) considera-se criança a pessoa menor de 12 anos de idade; e adolescente, a partir dos 12 e antes de completar 18 anos; e b) deve prevalecer o princípio do respeito à sua opinião e vontade.

A assistência à saúde de crianças ou adolescentes menores de 18 anos em abortamento deve, pois, submeter-se ao princípio da proteção integral. Se a revelação for feita para preservá-la de danos, estaria afastado o crime de revelação de segredo profissional. Entretanto, a revelação do fato também pode lhe acarretar prejuízos ainda mais graves, como o seu afastamento do serviço de saúde e perda da confiança nos profissionais que a assistem. A decisão, qualquer que seja, deve estar justificada no prontuário da adolescente.

Da objeção de consciência

Código de Ética Médica: "o médico deve exercer a profissão com ampla autonomia, não sendo obrigado a prestar serviços profissionais a quem ele não deseje, salvo na ausência de outro médico, em casos de urgência, ou quando sua negativa possa trazer danos irreversíveis ao paciente" (art. $7^{\circ}$ ). É seu direito "indicar o procedimento adequado ao paciente observado as práticas reconhecidamente aceitas e respeitando as normas legais vigentes no país" (art. 21) e "recusar a realização de atos médicos que, embora permitidos por lei, sejam contrários aos ditames de sua consciência" (art. 28). É vedado "descumprir legislação específica nos casos de transplante de ór- 
gãos ou tecidos, esterilização, fecundação artificial e abortamento" (art. 43) e "efetuar qualquer procedimento médico sem o esclarecimento e o consentimento prévios do paciente ou de seu responsável legal, salvo em iminente perigo de vida" (art. 48).

Não cabe objeção de consciência:

a) em caso de necessidade de abortamento por risco de vida para a mulher;

b) em qualquer situação de abortamento juridicamente permitido, na ausência de outro(a) médico(a) que o faça e quando a mulher puder sofrer danos ou agravos à saúde em razão da omissão do(a) médico(a);

c) no atendimento de complicações derivadas de abortamento inseguro, por se tratarem de casos de urgência.

Em caso de omissão, o(a) médico(a) pode ser responsabilizado(a) civil e criminalmente pela morte da mulher ou pelos danos físicos e mentais que ela venha a sofrer, pois podia e devia agir para evitar tais resultados (Código Penal, art. 13, § 2).

É dever do(da) médico(a) informar à mulher sobre suas condições e direitos e, em caso que caiba a objeção de consciência, garantir a atenção ao abortamento por outro(a) profissional da instituição ou de outro serviço. Não se pode negar o pronto atendimento à mulher em qualquer caso de abortamento, afastando-se, assim, situações de negligência, omissão ou postergação de conduta que violem os direitos humanos das mulheres.

É dever do Estado manter, nos hospitais públicos, profissionais que realizem o abortamento. Caso a mulher venha a sofrer prejuízo de ordem moral, física ou psíquica em decorrência da omissão, poderá haver responsabilização pessoal e/ou institucional. 


\section{OBRIGAÇÕES INSTITUCIONAIS:}

Embora exista o direito do médico à objeção de consciência dentro dos limites acima descritos, é OBRIGAÇÃO da INSTITUIÇÃO oferecer aos usuários do SUS todos os seus direitos, inclusive o da interrupção das gestações nos casos previstos em Lei. Qualquer forma de exposição ou negação dos serviços a que tem direito podem ser requeridos e/ou questionados à luz da justiça. Portanto é importante que os gestores e diretores clínicos estejam preparados para a implementação destes serviços nos hospitais públicos do País.

Referenciais da bioética no abortamento

A atenção humanizada às mulheres em abortamento pressupõe o respeito aos princípios fundamentais da Bioética (ética aplicada à vida): a) autonomia: direito da mulher de decidir sobre as questões relacionadas ao seu corpo e à sua vida; b) beneficência: obrigação ética de se maximizar o benefício e minimizar o dano (fazer o bem); c) não maleficência: a ação deve sempre causar o menor prejuízo à paciente, reduzindo os efeitos adversos ou indesejáveis de suas ações (não prejudicar) e d) justiça: o(a) profissional de saúde deve atuar com imparcialidade, evitando que aspectos sociais, culturais, religiosos, morais ou outros interfiram na relação com a mulher.

Em todo caso de abortamento, a atenção à saúde da mulher deve ser garantida prioritariamente, provendo-se a atuação multiprofissional e, acima de tudo, respeitando a mulher na sua liberdade, dignidade, autonomia e autoridade moral e ética para decidir, afastando-se preconceitos, estereótipos e discriminações de quaisquer natureza, que possam negar e desumanizar esse atendimento.

Diante de um caso de abortamento inseguro, adote, do ponto de vista ético, a conduta necessária: "Não fazer juízo de valor e não julgar", pois o dever de todos os profissionais de saúde é acolher condignamente e envidar esforços para garantir a sobrevivência da mulher e não causar quaisquer transtornos e constrangimentos.

A atenção humanizada às mulheres em abortamento é direito de toda mulher e dever de todo(a) profissional de saúde. 


\section{ACOLHER E ORIENTAR}

Quando as mulheres chegam aos serviços de saúde em processo de abortamento sua experiência é física, emocional e social. Geralmente, elas verbalizam as queixas físicas, demandando solução, e calam-se sobre suas vivências e sentimentos. A mulher que chega ao serviço de saúde em situação de abortamento espontâneo, induzido ou provocado, está passando por um momento difícil e pode ter sentimentos de solidão, angústia, ansiedade, culpa, autocensura, medo de falar, de ser punida, de ser humilhada, sensação de incapacidade de engravidar novamente. Todos esses sentimentos se misturam no momento da decisão pela interrupção, sendo que para a maioria das mulheres, no momento do pós-abortamento, sobressai o sentimento de alívio.

O acolhimento e a orientação são elementos importantes para uma atenção de qualidade e humanizada às mulheres em situação de abortamento. Acolher, segundo o dicionário Aurélio é: "dar acolhida a, atender, dar crédito a, dar ouvidos a, admitir, aceitar, tomar em consideração". Pode também ser definido como "receber bem, ouvir a demanda, buscar formas de compreendê-la e solidarizar-se com ela" (PAIDÉIA, 2002).

Acolhimento é o tratamento digno e respeitoso, a escuta, o reconhecimento e a aceitação das diferenças, o respeito ao direito de decidir de mulheres e homens, assim como o acesso e a resolubilidade da assistência à saúde.

A orientação pressupõe o repasse de informações necessárias à condução do processo pela mulher como sujeito da ação de saúde, à tomada de decisões e ao autocuidado, em consonância com as Diretrizes do Sistema Único de Saúde (SUS). É muito importante que o profissional certifique-se de que cada dúvida e preocupação das mulheres sejam devidamente esclarecidas para garantir uma decisão informada.

A ação de orientar deverá promover a autodeterminação, segundo o princípio ético da autonomia. 


\subsection{NÃO JULGAR}

A capacidade de escuta, sem prejulgamentos e imposição de valores, a capacidade de lidar com conflitos, a valorização das queixas e a identificação das necessidades são pontos básicos do acolhimento que poderão incentivar as mulheres a falarem de seus sentimentos e necessidades. Cabe ao profissional adotar uma "atitude terapêutica", buscando desenvolver uma escuta ativa e uma relação de empatia, que é a capacidade de criar uma comunicação sintonizada a partir das demandas das mulheres, assim como a possibilidade de se colocar no lugar do outro.

\subsection{ACOLHIMENTO É TAREFA DA EQUIPE DE SAÚDE}

Ao lidar com o atendimento ao abortamento, a equipe de saúde necessita refletir sobre a influência de suas convicções pessoais em sua prática profissional, para que dessa forma possa ter uma atitude destituída de julgamentos arbitrários e rotulações. Essa prática não é fácil, uma vez que muitos cursos de graduação e a formação em serviço não têm propiciado uma dissociação entre os valores individuais (morais, éticos, religiosos) e a prática profissional, muito pelo contrário, não preparam os profissionais para que possam lidar com os sentimentos, com a questão social, enfim, com elementos que vão além da prática biomédica.

Promover o acolhimento e fornecer as informações deve ser uma prática de todos os profissionais da equipe multiprofissional e devem estar presentes de forma transversal durante todo o contato com a mulher. Mais do que um dos passos do atendimento, o acolhimento é uma prática educativa que deverá refletir a qualidade da relação profissional de saúde/ usuária na perspectiva de construção de um novo modelo de atendimento. Para isso, os profissionais deverão estar devidamente sensibilizados e capacitados para incorporar o acolhimento e a orientação como uma prática cotidiana da assistência.

Devemos considerar que o papel de cada profissional de saúde na promoção do acolhimento e da orientação está relacionado à sua formação profissional. No tocante à escuta, é fundamental considerar a atenção psicossocial às mulheres em abortamento, integrando assisten- 
tes sociais e psicólogos no atendimento, com suas respectivas especificidades na atenção à saúde, quando possível. Deve-se considerar que os enfoques da psicologia e do serviço social podem ser diferenciados no trato das questões emocionais, relacionais e sociais. A enfermagem também tem um papel diferenciado por estar presente na porta de entrada, durante o procedimento obstétrico e na fase de recuperação clínica da mulher na unidade de saúde.

\subsection{ROTEIRO DE CONVERSA}

Do ponto de vista da escuta e da orientação oferecida pela psicologia, alguns aspectos podem ser aprofundados a depender da disponibilidade da mulher e das condições do serviço para esse atendimento. Podem estar incluídas no roteiro de conversa questões como: a maternidade e o desejo de ser e não ser mãe, sexualidade, relacionamento com o parceiro. Assim como, na perspectiva da prevenção da repetição do abortamento, é importante o espaço para elaboração subjetiva da experiência, com a verbalização dos sentimentos, a compreensão dos significados do abortamento no contexto de vida de cada mulher e dos motivos que levaram ao surgimento de uma gravidez não planejada.

\subsubsection{Mudança de postura}

Por envolver questões subjetivas de quem atende e quem é atendida, o tema do abortamento pressupõe sensibilização da equipe de saúde, visando à mudança de postura, de forma continuada. Nesse sentido, podem ajudar: discussões coletivas, supervisões clínicas, troca de preocupações, o confrontar de atitudes e convicções implícitas no atendimento, reuniões e oficinas de sensibilização e capacitação sobre sexualidade e práticas reprodutivas.

\subsubsection{Atenção humanizada}

Promover o acolhimento, a informação, a orientação e o suporte emocional no atendimento favorece a atenção humanizada por meio da interação da equipe com a clientela, o que determina as percepções des- 
ta quanto à qualidade da assistência, melhora da relação profissional de saúde/usuária, aumenta a capacidade de resposta do serviço e o grau de satisfação das mulheres com o serviço prestado, assim como influencia na decisão pela busca de um futuro atendimento. Nos casos de abortamento por estupro, o profissional deverá atuar como facilitador do processo de tomada de decisão, respeitando-a.

\subsection{ESCUTA QUALIFICADA}

Todos os profissionais de saúde devem promover a escuta privilegiada, evitando julgamentos, preconceitos e comentários desrespeitosos, com uma abordagem que respeite a autonomia das mulheres e seu poder de decisão, procurando estabelecer uma relação de confiança.

3.4.1 É responsabilidade da equipe:

- Respeitar a fala da mulher, lembrando que nem tudo é dito verbalmente, auxiliando-a a contatar com os seus sentimentos e elaborar a experiência vivida, buscando a autoconfiança.

- Organizar o acesso da mulher, priorizando o atendimento de acordo com necessidades detectadas.

- Identificar e avaliar as necessidades e riscos dos agravos à saúde em cada caso, resolvendo-os, conforme a capacidade técnica do serviço, ou encaminhando para serviços de referência, grupos de mulheres e organizações não governamentais (ONGs) feministas.

- Dar encaminhamentos aos problemas apresentados pelas mulheres, oferecendo soluções possíveis e priorizando o seu bem-estar e comodidade.

- Garantir a privacidade no atendimento e a confidencialidade das informações.

- Realizar os procedimentos técnicos de forma humanizada e informando às mulheres sobre as intervenções necessárias. 
3.4.2 Para os profissionais de saúde mental e serviço social:

- Prestar apoio emocional imediato e encaminhar, quando necessário, para o atendimento continuado em médio prazo.

- Reforçar a importância da mulher respeitando o estado emocional em que se encontra, adotando uma postura autocompreensiva, que busque a autoestima.

- Identificar as reações do grupo social (famílias, amigos, colegas) em que está envolvida/inserida.

- Perguntar sobre o contexto da relação em que se deu a gravidez e as possíveis repercussões do abortamento no relacionamento com o parceiro.

- Conversar sobre gravidez, aborto inseguro, menstruação, saúde reprodutiva e direitos sexuais e reprodutivos.

\subsubsection{Informar e orientar:}

- Estar atento às preocupações das mulheres, aceitando as suas percepções e saberes, passando informações que atendam às suas necessidades e perguntas.

- Estabelecer uma comunicação efetiva, estando atento à comunicação não verbal (gestos, expressões faciais). Utilizar linguagem simples, aproximativa, inteligível e apropriada ao universo da usuária.

- Informar sobre os procedimentos e como serão realizados, sobre as condições clínicas da usuária, os resultados de exames, os cuidados para evitar complicações posteriores e o acompanhamento pós-abortamento.

- Orientar quanto à escolha contraceptiva no momento pósabortamento, informando, inclusive, sobre a contracepção de emergência. 


\subsubsection{Orientações clínicas}

- SINAIS E SINTOMAS QUE REQUEREM ATENDIMENTO DE EMERGÊNCIA:

- CÓLICAS POR TEMPO PROLONGADO.

- SANGRAMENTO PROLONGADO (MAIS DE DUAS SEMANAS).

- SANGRAMENTO MAIS ABUNDANTE DO QUE UMA MENSTRUAÇÃO NORMAL.

- DOR INTENSA OU PROLONGADA.

- FEBRE, CALAFRIOS OU MAL-ESTAR GERAL.

- DESMAIOS.

\subsubsection{Orientações gerais}

- Informar sobre a rotina de higiene pessoal, reinício da atividade sexual, volta da menstruação e planejamento reprodutivo. O retorno da atividade sexual pós-abortamento não complicado pode ocorrer tão logo a mulher assim o desejar.

- A fertilidade retornará logo após o procedimento, de forma que é necessária a orientação de planejamento reprodutivo e o acesso a métodos contraceptivos.

- Agendar retorno para no máximo 15 dias para revisão pósabortamento.

- Orientar sobre o que fazer e onde encontrar assistência de emergência.

- Orientar sobre complicações.

SINAIS DE RECUPERAÇÃO NORMAL

UM POUCO DE CÓLICA UTERINA DURANTE OS PRÓXIMOS DOIS DIAS, QUE PODE SER ALIVIADA COM ANALGÉSICOS LEVES, E UM POUCO DE SANGRAMENTO, QUE NÃO DEVE EXCEDER DE UMA MENSTRUAÇÃO NORMAL.

UMA NOVA MENSTRUAÇÃO PODE OCORRER DENTRO DAS PRÓXIMAS 4-8 SEMANAS. 


\section{ATENÇÃO CLÍNICA AO ABORTAMENTO}

\subsection{ASPECTOS CLÍNICOS}

Abortamento é a interrupção da gravidez até a $20^{\mathrm{a}}$ ou $22^{\mathrm{a}}$ semana e com produto da concepção pesando menos que $500 \mathrm{~g}$. Aborto é o produto da concepção eliminado no abortamento.

São várias as causas de abortamento, contudo, na maioria das vezes, a causa permanece indeterminada. Muitas gestações são interrompidas por decisão pessoal da mulher.

Deve-se oferecer a todas as mulheres exames para classificação sanguínea, e administrar imunoglobulina anti-D naquelas Rh não sensibilizadas, teste sorológico para sífilis e pesquisa do HIV.

Os abortamentos podem ser classificados em:

- ameaça de abortamento;

- abortamento completo;

- abortamento inevitável/incompleto;

- abortamento retido;

- abortamento infectado;

- abortamento habitual;

- abortamento eletivo previsto em lei.

\subsubsection{Ameaça de abortamento}

O sangramento genital é de pequena a moderada intensidade, podendo existir dores, tipo cólicas, geralmente pouco intensas. O colo uterino (orifício interno) encontra-se fechado, o volume uterino é compatível com o esperado para a idade gestacional, e não existem sinais de infecção. $\mathrm{O}$ exame de ultrassom mostra-se normal, com feto vivo, podendo encontrar pequena área de descolamento ovular. 
Não existe indicação de internação hospitalar, a mulher deve ser orientada para ficar em repouso, utilizar analgésico se apresentar dor, evitar relações sexuais durante a perda sanguínea, e retornar ao atendimento de pré-natal. Nos casos em que não ocorre regressão das alterações ou se surgir febre, dor pélvica localizada ou sangramento com odor fétido deve a mulher retornar ao serviço de saúde para nova avaliação.

\subsubsection{Abortamento completo}

Geralmente ocorre em gestações com menos de oito semanas. A perda sanguínea e as dores diminuem ou cessam após a expulsão do material ovular. O colo uterino (orifício interno) pode estar aberto e o tamanho uterino mostra-se menor que o esperado para a idade gestacional. No exame de ultrassom encontra-se cavidade uterina vazia ou com imagens sugestivas de coágulos.

A conduta nesse caso é de observação, com atenção ao sangramento e/ou à infecção uterina. Quando persiste o sangramento, podemos prescrever uterotônicos, ou pode ser realizada uma aspiração manual intrauterina (Amiu) com cânula bem fina. É importante ressaltar que a curetagem uterina deve ser usada apenas quando a aspiração não estiver disponível.

\subsubsection{Abortamento inevitável/incompleto}

O sangramento é maior que na ameaça de abortamento, que diminui com a saída de coágulos ou de restos ovulares, as dores costumam ser de maior intensidade que na ameaça, e o orifício cervical interno encontra-se aberto. O exame de ultrassom confirma a hipótese diagnóstica, embora não seja imprescindível.

Em gestações com menos de 12 semanas, pelo tamanho uterino, indica-se a aspiração manual ou elétrica intrauterina por ser mais segura e permitir o esvaziamento mais rápido. Quando não for possível empregar essa técnica, realiza-se a curetagem uterina. Em úteros compatíveis com gestação superior a 12 semanas, principalmente se o feto ainda estiver dentro do útero, emprega-se o misoprostol na dose de 200 mcg de 12/12 
horas, via vaginal, em ciclos de 48 horas de tratamento, com 3 a 5 dias de intervalo. Após a expulsão, persistindo o sangramento, se o tamanho uterino for menor ou igual a gestação de 12 semanas podemos realizar a complementação por aspiração uterina. Se o volume uterino for maior de 12 semanas utilizamos a curetagem uterina. Também é importante avaliar a perda sanguínea e, se necessário, far-se-á transfusão sanguínea. Em situações onde o esvaziamento é emergencial (hemorragias graves ou infecções graves), o uso do misoprostol deve ser evitado devido ao tempo de resposta necessário para o esvaziamento medicamentoso.

\subsubsection{Abortamento retido}

Em geral, o abortamento retido cursa com regressão dos sintomas e sinais da gestação, o colo uterino encontra-se fechado e não há perda sanguínea. $O$ exame de ultrassom revela ausência de sinais de vitalidade ou a presença de saco gestacional sem embrião (ovo anembrionado). Pode ocorrer o abortamento retido sem os sinais de ameaça.

Trata-se com misoprostol quando o útero corresponder à gestação maior que 12 semanas e por meio de Amiu com útero correspondente a menos de 12 semanas.

\subsubsection{Abortamento infectado}

Com muita frequência está associado a manipulações da cavidade uterina pelo uso de técnicas inadequadas e inseguras. Estas infecções são polimicrobianas e provocadas, geralmente, por bactérias da flora vaginal. São casos graves e devem ser tratados, independentemente da vitalidade do feto. As manifestações clínicas mais frequentes são: elevação da temperatura, sangramento genital com odor fétido acompanhado de dores abdominais ou eliminação de secreção purulenta através do colo uterino. Na manipulação dos órgãos pélvicos, através do toque vaginal, a mulher pode referir bastante dor, e deve-se sempre pensar na possibilidade de perfuração uterina.

Os seguintes exames são necessários para melhor avaliação da mulher, bem como para seu seguimento: hemograma com contagem de 
plaquetas; urina tipo l; coagulograma; hemocultura; cultura da secreção vaginal e do material endometrial, também para anaeróbios; raios- $x$ do abdome; ultrassonografia pélvica ou de abdome total; e tomografia, principalmente para definir coleções intracavitárias. No tratamento é fundamental o restabelecimento das condições vitais com soluções parenterais ou com sangue, principalmente se a hemoglobina for inferior a $8 \mathrm{~g} \%$. Iniciar antibioticoterapia, junto com as medidas de suporte, dando preferência aos quimioterápicos de largo espectro. Pode ser utilizado um anaerobicida (metronidazol - 500g - $1 \mathrm{~g} \mathrm{IV}$, a cada 6 horas, por 7 - 10 dias ou clindamicina - 600 - 900mg, a cada 6 ou 8h IV, por 7 - 10 dias), associado com um aminoglicosídeo (gentamicina - 1,5mg/ $\mathrm{Kg} /$ dose IV ou IM, a cada 8h, por 7 - 10 dias ou amicacina - $15 \mathrm{mg} / \mathrm{Kg} / \mathrm{dia}$, a cada 6 - 8h IV ou IM, por 7 - 10 dias).

O esvaziamento uterino, naqueles úteros com tamanho compatível com gestação até 12 semanas, deve ser realizado, preferencialmente, por aspiração manual intrauterina (Amiu), por apresentar menores taxas de complicações, reduzida necessidade de dilatação cervical e promover a aspiração do material infectado. Na realização desse procedimento, atentar para o fato de que a perda do vácuo pode significar perfuração uterina prévia. Na impossibilidade do uso da Amiu pode-se empregar a curetagem uterina; em ambas, o esvaziamento uterino deve ser feito sob infusão de ocitocina. Nos casos mais graves, acompanhados de peritonite e que demoram a dar uma resposta satisfatória, deve-se proceder a laparotomia exploradora e, se necessário, realizar retirada de órgãos pélvicos. A persistência de febre após os cuidados iniciais pode traduzir abscessos pélvicos ou tromboflebite. Nesse caso indica-se a utilização da heparina.

\subsubsection{Abortamento habitual}

Caracteriza-se pela perda espontânea e consecutiva de três ou mais gestações antes da $22^{a}$ semana. É primário quando a mulher jamais conseguiu levar a termo qualquer gestação, e secundário quando houve uma gravidez a termo. Estas mulheres devem ser encaminhadas para tratamento especializado, onde seja possível identificar as causas e realizados tratamentos específicos. 


\subsubsection{Abortamento eletivo previsto em lei}

Nos casos em que exista indicação de interrupção da gestação, obedecida a legislação vigente e, por solicitação da mulher ou de seu representante, deve ser oferecida à mulher a opção de escolha da técnica a ser empregada: abortamento farmacológico, procedimento aspirativo (Amiu) ou a dilatação e curetagem.

Tal escolha deverá ocorrer depois de adequados esclarecimentos das vantagens e desvantagens de cada método, suas taxas de complicações e efeitos adversos. Para maiores informações sobre abortamento eletivo nos casos de violência sexual, consultar a Norma Técnica de Prevenção e Tratamento dos Agravos Resultantes da Violência Sexual contra Mulheres e Adolescentes.

\subsection{ESCOLHENDO AS TÉCNICAS DE ESVAZIAMENTO UTERINO}

O abortamento seguro, nas razões legalmente admitidas no Brasil, e o tratamento do abortamento, constituem direito da mulher que deve ser respeitado e garantido pelos serviços de saúde. Para o exercício pleno desse direito, é fundamental que a escolha do tipo de método para o abortamento faça parte de um processo de decisão compartilhada entre a mulher e os profissionais de saúde. Os diferentes métodos disponíveis devem ser igualmente oferecidos de forma apropriada, garantindo que a decisão seja a mais livre, consciente e informada possível. Além disso, todo o processo de escolha deve estar fundamentado no respeito aos princípios de autonomia e autodeterminação da mulher.

Recomenda-se que os serviços de saúde elaborem normas ou rotinas internas, incluindo-se fluxogramas e procedimentos, com a finalidade de enfatizar e promover o compromisso dos profissionais e da instituição. A normatização deve considerar as capacidades e habilidades específicas de cada serviço. A equipe multidisciplinar deve dispor de um espaço específico para a avaliação e o monitoramento do serviço e da qualidade da assistência, incluindo a discussão de questões éticas.

Durante o primeiro trimestre da gravidez consideram-se métodos aceitáveis a aspiração intrauterina (manual ou elétrica), o aborta- 
mento farmacológico e a curetagem uterina. A ordem de escolha para os diferentes métodos depende das condições de cada serviço e da preferência da mulher, além da necessária avaliação do risco-benefício de cada procedimento.

Deve-se adotar critérios que considerem e respeitem:

1) a disponibilidade de métodos em cada serviço de saúde;

2) a capacitação, habilidade e rotinas dos serviços de saúde para cada método;

3) as condições clínicas, sociais e psicológicas da mulher.

No segundo trimestre, o abortamento farmacológico constitui método de eleição, podendo ser complementado, após a expulsão fetal, com curetagem ou aspiração uterina, segundo as condições clínicas da mulher. A interrupção da gravidez por meio de microcirurgia ou microcesariana deve ser reservada para condições excepcionais.

\subsubsection{Abortamento farmacológico}

É a utilização de fármacos para indução do abortamento ou abreviação do abortamento em curso. Toda mulher grávida que solicita interrupção da gestação e cumpre com as condições estabelecidas pela lei, pode optar pela interrupção farmacológica da gravidez, tanto no primeiro como no segundo trimestre da gestação.

No Brasil tem-se disponível o misoprostol e a ocitocina, conforme a Portaria MS/GM no 1.044, de 5 de maio de 2010 - Aprova-se a 7a edição da Rename - Relação Nacional de Medicamentos Essenciais - 2010 (Publicada no Diário Oficial da União n 85, Seção I - pág. 58, de 6 de maio de 2010) e a Resolução-RDC no 13, de 26 de março de 2010, que dispõe sobre a atualização do Anexo I, Listas de Substâncias Entorpecentes, Psicotrópicas, Precursoras e Outras sob Controle Especial, da Portaria MS/SVS n 344, de 12 de maio de 1998 e dá outras providências. 
As drogas utilizadas para interrupção da gravidez não devem ser usadas nos casos de conhecida intolerância.

Nos casos de gestação molar, não devem ser primeira opção e somente devem ser usadas excepcionalmente e sob estrita vigilância. Para mulheres portadoras de distúrbios da coagulação, incluindo uso de anticoagulantes, e entre as cardiopatas graves, deve-se manter vigilância rigorosa durante o uso das drogas. No abortamento de segundo trimestre, mantêm-se as mesmas condições assinaladas para o primeiro trimestre, acrescidas da presença de cicatriz uterina.

O possível risco de sangramento excessivo e o eventual efeito psicológico de observar a expulsão do conteúdo uterino devem ser discutidos com a mulher, devendo a paciente permanecer internada até a finalização do processo.

Nos casos de interrupção da gestação, a mulher deverá permanecer internada, até a conclusão do procedimento.

4.2.2 Misoprostol

\section{ESVAZIAMENTO UTERINO NO $1^{\circ}$ TRIMESTRE GESTACIONAL ( ABORTO LEGAL OU ABORTO RETIDO)}

1a opção: Misoprostol 4 cápsulas de $200 \mathrm{mcg}$ via vaginal a cada 12 horas. ( 3 doses $-0,12$ e 24 horas).

2a opção: Misoprostol 2 cápsulas de $200 \mathrm{mcg}$ via vaginal a cada 8 horas ( 3 doses - 0,8 e 16 horas).

$3^{\text {a }}$ opção: Misoprostol 1 cápsula de $200 \mathrm{mcg}$ via vaginal a cada 6 horas ( 4 doses $-0,6,12$ e 18 horas).

Observação: Os últimos trabalhos científicos têm demonstrado que a $1^{\text {a }}$ opção apresenta maior eficácia, com expulsão do produto da concepção dentre as primeiras 24 horas podendo alguns casos demorarem 48 ou 72 horas, sem aumento dos efeitos colaterais. 


\section{ESVAZIAMENTO UTERINO NO $2^{\circ}$ TRIMESTRE GESTACIONAL (ÓBITO FETAL INTRAUTERINO)}

De 13 a 17 semanas - misoprostol 1 cápsula de 200mcg via vaginal cada 6 horas.(4 doses)

De 18 a 26 semanas - misoprostol 1 cápsula de 100mcg via vaginal cada 6 horas.(4 doses)

Observação: Se necessário repetir após 24 horas

\section{ESVAZIAMENTO UTERINO NO $3^{\circ}$ TRIMESTRE GESTACIONAL (ÓBITO FETAL INTRAUTERINO)}

- Se o colo não está maduro, colocar misoprostol 1 cápsula de $25 \mathrm{mcg}$ via vaginal e repetir a dose se necessário após 6 horas.

- Se não houver resposta utilizar misoprostol 2 cápsulas de $25 \mathrm{mcg}$ via vaginal de $6 / 6$ horas até 4 doses. Não usar mais de 50 mcg por vez.

- Não administrar uma nova dose se já houver atividade uterina.

- Não usar ocitocina dentro das seis horas após o uso do misoprostol.

\section{INDUÇÃO DO PARTO COM FETO VIVO}

Misoprostol 1 cápsula ( $25 \mathrm{mcg}$ ) via vaginal a cada 6 horas. Recomendado utilizar as doses durante o dia (7, 13 e 19 horas). Se não houver resultado repetir as doses no dia seguinte.

\section{AMOLECIMENTO DE COLO UTERINO PRÉVIO A AMIU OU CURETAGEM}

Misoprostol 2 cápsulas de 200mcg via vaginal, 3 a 4 horas antes do procedimento. 


\section{CONTRAINDICAÇÕES DO USO DE MISOPROSTOL}

- Cesárea anterior.

- Cirurgia uterina prévia.

- Paciente asmática.

- Uso concomitante com ocitocina.

- Placenta prévia.

No primeiro trimestre deve ser discutido com a mulher, que poderá decidir por não continuar esperando o aborto e solicitar o esvaziamento a qualquer momento, o que deve ser aceito pela equipe médica. Se a mulher aceitar, no primeiro trimestre, deve-se esperar até 72 horas ou 24 horas depois da última dose. Após 72 horas o esquema pode repetir-se ou ser utilizado um método alternativo, dependendo da decisão da mulher. Geralmente o colo uterino apresenta-se favorável para aspiração ou curetagem.

No segundo trimestre, como há menos alternativas, é preciso esperar mais tempo. Propõe-se repetir o tratamento em ciclos de 48 horas, com três a cinco dias de intervalo, repetidos até completado o abortamento ou até que a mulher, em conjunto com o clínico, decidam passar a outros procedimentos, como exemplo a associação com ocitocina.

Efeitos colaterais podem ocorrer com a utilização do misoprostol, tais como: diarreia, que deve ser tratada apenas com hidratação oral, vômitos, controlados com antieméticos, e sangramento genital excessivo, tratado com esvaziamento uterino, preferentemente por meio de aspiração manual ou elétrica.

\subsubsection{Aspiração Manual Intrauterina (Amiu)}

Procedimento que utiliza cânulas de Karman, com diâmetros variáveis, de 4 a $12 \mathrm{~mm}$, acopladas a seringa com vácuo, promovendo a retirada dos restos ovulares através da raspagem da cavidade uterina e por 
aspiração. Deve ser utilizada em gestações com menos de 12 semanas, em função do tamanho uterino, pois há necessidade do colo uterino ser justo à cânula para que o vácuo seja transferido da seringa para a cavidade uterina. Nos casos de abortamento infectado Amiu é a técnica de eleição. Nos casos de interrupção da gravidez previstos na legislação vigente no País, com menos de 12 semanas, deve-se empregar essa técnica. A aspiração manual intrauterina (Amiu) é o procedimento de escolha para tratamento do abortamento, sendo recomendada pela Organização Mundial da Saúde e pela Federação Internacional de Ginecologia e Obstetrícia (Figo).

\subsubsection{Curetagem uterina}

Estando o colo uterino aberto, ou dilatado previamente pelos dilatadores de Deninston ou velas de Hegar, introduz-se a cureta e promove-se uma raspagem da cavidade uterina, extraindo-se o material desprendido pelo instrumental. Por ter diâmetro variável e ser de material rígido (aço) pode provocar acidentes, tal como perfuração do útero. Por ser de utilização mais antiga, ainda é muito usada no Brasil. Nos casos do colo uterino estar fechado ou pouco dilatado, pode-se promover sua abertura por meio da dilatação cervical, embora esse procedimento não esteja isento de riscos. Nas gestações superiores a 12 semanas deve-se promover a indução farmacológica com misoprostol. Então, após a expulsão fetal, faz-se a curetagem uterina.

\subsection{ALÍVIO DA DOR}

O processo de abortamento é para muitas mulheres desconfortável e doloroso, necessitando, portanto, de atenção médica adequada para o controle da dor. Situações emocionais influenciam na percepção da mulher em sentir a dor e podem dificultar seus cuidados, exigindo do profissional de saúde atitudes amigáveis e tranquilizadoras. A intensidade da dor sofre influências da idade da gestação, idade da mulher, dilatação cervical, além do medo da mulher em relação ao procedimento proposto e sua compreensão em relação ao abortamento. Mulheres que já experimentaram a maternidade, em geral, queixam-se menos de desconforto provocado pela dor. Aquelas que apresentam história de uso frequente de analgésicos geralmente necessitam de maior atenção. 
A inadequação do controle da dor provoca nas mulheres sofrimentos desnecessários, além de aumentar suas ansiedades e de expor essas mulheres a mais complicações, provocando insatisfação quanto à qualidade da atenção prestada. Em todos os casos de atenção ao abortamento, quer na indução farmacológica ou nos outros procedimentos de esvaziamento (Amiu ou curetagem), a avaliação clínica criteriosa, esclarecimentos sobre os procedimentos que serão utilizados, apoio afetuoso, empático e humanizado, proporcionam ambiente favorável para uma abordagem menos medicamentosa, com menores riscos de complicações, menos custos, e mais rápida recuperação.

Deve-se oferecer medicamentos para alívio da dor a todas as mulheres. Aquelas que se apresentem em condições clínicas favoráveis, com úteros pequenos e com pouco conteúdo a ser esvaziado e satisfatória interação com a equipe de saúde, podem ser tratadas apenas com apoio verbal e anestesia paracervical. Utilizam-se outras drogas associadas quando a mulher necessitar, evitando-se sofrimentos desnecessários. Na maior parte dos procedimentos é suficiente o uso de analgésicos não narcóticos, com anestesia paracervical e/ou sedação. Algumas mulheres precisam receber drogas tranquilizantes, como o diazepan ou midazolan, quando a ansiedade passa a ser um componente prejudicial ao atendimento.

Em situações selecionadas, os usos de analgésicos narcóticos (petidina e morfina) podem ser empregados, atentando-se aos seus possíveis efeitos adversos, principalmente a depressão respiratória, devendo estar disponíveis materiais e drogas para reanimação.

A anestesia local ou bloqueio paracervical é realizado utilizandose lidocaína a 1\%, sem vasoconstrictor, injetando-se lentamente o anestésico na metade posterior do colo uterino (transição cérvice com a mucosa vaginal), às 5 e às 7 horas, com agulha fina (calibre 23 ou de insulina), a uma profundidade de $3-5 \mathrm{~mm}$, na quantidade de $3-8 \mathrm{ml}$ em cada ponto, tendo o cuidado de evitar a injeção intravenosa do anestésico. 
A anestesia geral deve ser empregada quando disponível e essa for a opção da mulher, devendo todos estar cientes dos riscos, dos aumentos dos custos e da permanência mais prolongada da mulher no hospital. A instituição hospitalar deve estar equipada e seus profissionais treinados para atuar nos casos de complicações. 


\section{PLANEJAMENTO REPRODUTIVO PÓS-ABORTAMENTO}

A mulher com complicações de abortamento, espontâneo ou por decisão pessoal, tem necessidade de cuidados destinados a protegê-la das consequências físicas e psicológicas do processo que está sofrendo, assim como evitar que volte a ser acometida do mesmo problema no futuro.

Sabe-se que o risco de ter um novo abortamento é maior entre as mulheres que já tiveram um abortamento, e aumenta com o número de abortamentos anteriores. Nos casos de aborto espontâneo de repetição, as mulheres precisam proteger-se de uma nova gravidez até serem encaminhadas a um serviço especializado que as ajude no diagnóstico e no tratamento de seu problema.

Nos casos de abortamento provocado, a adoção imediata de contracepção tem se mostrado como uma medida eficaz para reduzir o risco de novos abortamentos.

A mulher em situação de abortamento, muitas vezes, não está preocupada com o risco de uma nova gravidez e não usa métodos anticoncepcionais espontaneamente. Ela precisa da orientação dos provedores de serviço e de disponibilidade de métodos eficazes e aceitáveis na redução do risco de gravidez não desejada. Portanto, o atendimento da mulher com complicações de abortamento só será completo se acompanhado de orientação sobre anticoncepção e de oferta de métodos no pós-abortamento imediato.

\subsection{ORIENTAÇÃO EM PLANEJAMENTO REPRODUTIVO}

Em geral, a mulher que teve uma gestação interrompida por decisão pessoal não deseja uma gravidez logo em seguida, portanto, toda mulher que ingressa no hospital em abortamento deve ser acolhida e receber orientação anticoncepcional.

As orientações devem começar por informar que a recuperação da fertilidade pode ser quase que imediata após o abortamento e que, por conseguinte, a anticoncepção deve iniciar-se também de imediato, ainda 
que a mulher não deseje, tão logo, ter relações sexuais. A experiência mostra que a possibilidade do abortamento se repetir é maior justamente entre as mulheres que acham que não estarão expostas à gravidez nos meses ou anos seguintes e, por isso mesmo, não se protegem adequadamente. Esse maior risco deve ser comunicado às mulheres atendidas por abortamento para motivá-las a se proteger contra a gravidez não desejada.

Deve-se dar informações sobre todos os métodos aceitos no Brasil, inclusive sobre a eficiência de cada método para evitar a gravidez. Nesse sentido, o dispositivo intrauterino com cobre e os hormonais injetáveis trimestrais ou mensais têm-se demonstrado mais eficiente por não haver o risco de esquecimento. Nos casos de não aceitação ou impossibilidade de utilização desses métodos, a pílula e os métodos de barreira ganham lugar de destaque.

Outro método que deve ser destacado é a Anticoncepção Hormonal de Emergência (AHE), considerando que sempre haverá mulheres convictas de que não voltarão a ter relações sexuais em curto espaço de tempo e, por este motivo não usam métodos. Essas mulheres poderão estar expostas a relações sexuais inesperadas e não protegidas do risco de gravidez e de abortamento. A utilização da AHE poderá evitar a gravidez nesses casos.

Por outro lado, é necessário lembrar que os métodos destacados acima não protegem contra as infecções sexualmente transmitidas. Nesse sentido, não se pode deixar de prover informação completa sobre o uso de preservativos e sobre como obtê-los, promovendo o conceito de dupla proteção, contra a gravidez e as infecções de transmissão sexual.

\subsection{OFERTA DE MÉTODOS ANTICONCEPCIONAIS}

Idealmente, todos os métodos mencionados acima devem estar disponíveis no local onde se atende à mulher em abortamento, dando oportunidades às mulheres de iniciar o uso antes de receber alta. Em que pese a obrigatoriedade da orientação e oferta de métodos contraceptivos, as mulheres devem ter absoluta liberdade de aceitar ou não os métodos acima citados. 
Nos casos em que a mulher aceita um método, esse pode ser iniciado de imediato. No caso do DIU, deve-se oferecer a inserção no fim do esvaziamento uterino (Amiu ou curetagem) nas mulheres sem nenhum sinal ou suspeita de infecção, na alta hospitalar ou no retorno ao hospital ou à unidade de saúde dentro dos primeiros 15 dias pós-abortamento ou logo depois da primeira menstruação após o esvaziamento.

O injetável mensal ou trimestral pode ser administrado entre o dia do esvaziamento e o quinto dia pós-abortamento, da mesma forma que o anticoncepcional hormonal oral. Como muitas mulheres terão dificuldades em consultar na unidade de saúde dentro desses prazos, é necessário que os métodos estejam disponíveis no hospital que atende o abortamento para que as mulheres possam iniciar o método escolhido dentro do prazo recomendado. Reitera-se que a mulher pode engravidar caso reinicie sua vida sexual no primeiro mês pós-abortamento e não esteja protegida por algum método anticoncepcional.

\subsection{ABORTAMENTO ESPONTÂNEO E ORIENTAÇÃO CONCEPCIONAL}

Apesar de ser difícil distinguir se um abortamento é espontâneo ou provocado, sempre há que se considerar que a mulher tem direito à opção de ter um filho algum tempo após o abortamento. Por essa razão, é necessário que a mulher também receba orientação sobre o planejamento de uma nova gravidez.

A completa recuperação da mulher após um abortamento é relativamente rápida, sendo mais demorada se o abortamento ocorreu no $2^{\circ}$ trimestre da gestação. O retorno das relações sexuais, pós-abortamento não complicado, pode ocorrer tão logo a mulher deseje, assim ela deve ser orientada a usar um método contraceptivo por três meses para iniciar uma próxima gravidez em melhores condições físicas e emocionais. 



\section{REFERÊNCIAS}

ABORTO LEGAL: implicações éticas e religiosas. São Paulo: Católicas pelo Direito de Decidir. 2002.

ADESSE, L.; MONTEIRO, Mário. Magnitude do aborto no Brasil: aspectos epidemiológicos e culturais. [ S.I.: s. n. 2006].

ALEXANDER, S. Maternal health outcomes in Europe. European Journal of Obstetrics \& Gynecology and Reproductive Biology, v. 111, p. S78-87, 2003.

BRASIL. Ministério da Saúde. Assistência ao planejamento familiar. Brasília: Ministério da Saúde. 1996.

BRASIL. Ministério da Saúde. Manual de controle de doenças sexualmente transmissíveis. 3. ed., Brasília: Ministério da Saúde. 1999.

BRASIL. Ministério da Saúde. Parto, aborto e puerpério. Assistência humanizada à mulher. Brasília: Ministério da Saúde. 2001.

BRASIL. Ministério da Saúde. Estudo da mortalidade de mulheres de 10 a 49 anos, com ênfase na mortalidade materna: relatório final. Brasília: Ministério da Saúde. 2006

COMPTE, G. M. Mortalidade materna. Salvador: [s. n.], 1993. Dissertação (mestrado). Universidade Federal da Bahia. Instituto de Saúde Coletiva.

CORRÊA, S.; FREITAS, A. Atualizando os dados sobre a interrupção voluntária da gravidez no Brasil. Estudos Feministas, v. 5, n. 2, p. 389-396, 1997.

DINIZ, D. Aborto e saúde pública: 20 anos de pesquisas no Brasil. [S.I.], 2008.

DREZETT, J. Painel de descriminalização do aborto. Brasília, 2005. Realizado em Brasília e promovido pela Secretaria Especial de Políticas para Mulheres. Disponível em: <http://www.ipas.org.br/arquivos/jefferson/problema_saude05.doc>. Acesso em: 17 nov. 2008.

INTERNATIONAL PLANNED PARENTHOOD FEDERATION. Morte e negação: abortamento inseguro e pobreza. [Chicago], 2006.

INTERNATIONAL PLANNED PARENTHOOD FEDERATION (IPPF). Strategies for the treatment and prevention of sexual assault. Chicago, 1995. 
MENEZES, G. M. S.; AQUINO, E. M. L. Mortalidade materna na Bahia. Salvador. 1998. Relatório de Pesquisa.

MINAYO, Maria Cecília de Souza. A inclusão da violência na agenda da saúde: trajetória histórica. Ciênc. saúde coletiva, Rio de Janeiro2008. Disponível em: <http://www.scielo.br/scielo.php?script=sci_arttext\&pid=S141381232006000500015\&lng=en\&nrm=iso >. Acesso em: 12 Sep 2008. doi: $10.1590 / \mathrm{S} 1413-81232006000500015$

ORGANIZAÇÃO MUNDIAL DE SAÚDE-OMS. Abortamento seguro: orientação técnica e de políticas para os sistemas de saúde. Genebra, 2004.

RECIFE. Prefeitura Municipal. DIEVS. Mortalidade materna: definição, dados epidemiológicos, vigilância epidemiológica e ficha de investigação. In: SEGATO, Rita Laura. Las estructuras elementales de la violencia: ensayos sobre género entre la antropología, el psicoanálisis y los derechos humanos. Buenos Aires. Universidad Nacional de Quilmes, 2003. (mímeo)

SEGATO, Rita Laura. El sistema penal como pedagogia de la irresponsabilidad y el proyecto "Habla preso: el derecho humano a la palabra em la carcel". Serie Antropológica 329

SIRIMARCO, Mariana. Marcas de género, cuerpos de poder. Discursos de producción de masculinidad em la conformación del sujeto policial.

SIMPOSIO NACIONAL DE VIOLENCIA CONTRA LA MUJER. Un problema de ética y justicia. La Paz: Ipas Bolivia. 2002.

THE ALAN GUTTMACHHER INSTITUTE. Aborto clandestino: uma realidade latino-americana. [Nova lorque],1994.

THE ALAN GUTTMACHHER INSTITUTE. Sharing responsability: women, society and abortion: worldwide [S.I.], 1999. 57 p. (Special Report).

THE ALAN GUTTMACHER INSTITUTE Facts on Induced Abortion Worldwide. [S.I.], 2008. (special report). Disponível, em: <http://www.guttmacher.org/ pubs/fb_IAW.pdf>. Acesso em: 17 nov. 2008.

VALONGUEIRO, S. A. Mortalidade materna em Pernambuco: um estudo quantitativo e qualitativo. Belo Horizonte, 1996. Dissertação (mestrado). CEDEPLAR/Universidade Federal de Minas Gerais. 


\section{ANEXOS}

Anexo A

PORTARIA MS/GM No 1.508, DE 1 DE SETEMBRO DE 2005.

Dispõe sobre o Procedimento de Justificação e Autorização da Interrupção da Gravidez nos casos previstos em lei, no âmbito do Sistema Único de Saúde-SUS.

O MINISTRO DE ESTADO DA SAÚDE, no uso das atribuições que lhe confere o inciso Il do parágrafo único do art. 87 da Constituição Federal, e

Considerando que o Código Penal Brasileiro estabelece como requisitos para o aborto humanitário ou sentimental, previsto no inciso II do art. 128, que ele seja praticado por médico e com o consentimento da mulher;

Considerando que o Ministério da Saúde deve disciplinar as medidas assecuratórias da licitude do procedimento de interrupção da gravidez nos casos previstos em lei quando realizado no âmbito do SUS;

Considerando a necessidade de se garantir aos profissionais de saúde envolvidos no referido procedimento segurança jurídica adequada para a realização da interrupção da gravidez nos casos previstos em lei; e

Considerando que a Norma Técnica sobre Prevenção e Tratamento dos Agravos Resultantes da Violência Sexual contra Mulheres e Adolescentes não obriga as vítimas de estupro da apresentação do Boletim de Ocorrência para sua submissão ao procedimento de interrupção da gravidez no âmbito do SUS, 
Art. $1^{\circ}$ O Procedimento de Justificação e Autorização da Interrupção da Gravidez nos casos previstos em lei é condição necessária para adoção de qualquer medida de interrupção da gravidez no âmbito do Sistema Único de Saúde, excetuados os casos que envolvem riscos de morte à mulher.

Art. $2^{\circ}$ O Procedimento de Justificação e Autorização da Interrupção da Gravidez nos casos previstos em lei compõe-se de quatro fases que deverão ser registradas no formato de Termos, arquivados anexos ao prontuário médico, garantida a confidencialidade desses termos.

Art. $3^{\circ}$ A primeira fase é constituída pelo relato circunstanciado do evento, realizado pela própria gestante, perante dois profissionais de saúde do serviço.

Parágrafo único. O Termo de Relato Circunstanciado deverá ser assinado pela gestante ou, quando incapaz, também por seu representante legal, bem como por dois profissionais de saúde do serviço, e conterá:

I - local, dia e hora aproximada do fato;

II - tipo e forma de violência;

III - descrição dos agentes da conduta, se possível; e

IV - identificação de testemunhas, se houver.

Art. 4 A segunda fase dá-se com a intervenção do médico que emitirá parecer técnico após detalhada anamnese, exame físico geral, exame ginecológico, avaliação do laudo ultrassonográfico e dos demais exames complementares que porventura houver.

§ 1० Paralelamente, a mulher receberá atenção e avaliação especializada por parte da equipe de saúde multiprofissional, que anotará suas avaliações em documentos específicos. 
$\S 2^{\circ}$ Três integrantes, no mínimo, da equipe de saúde multiprofissional subscreverão o Termo de Aprovação de Procedimento de Interrupção da Gravidez, não podendo haver desconformidade com a conclusão do parecer técnico.

$\S 3^{\circ}$ A equipe de saúde multiprofissional deve ser composta, no mínimo, por obstetra, anestesista, enfermeiro, assistente social e/ou psicólogo.

Art. $5^{\circ}$ A terceira fase verifica-se com a assinatura da gestante no Termo de Responsabilidade ou, se for incapaz, também de seu representante legal, e esse Termo conterá advertência expressa sobre a previsão dos crimes de falsidade ideológica (art. 299 do Código Penal) e de aborto (art. 124 do Código Penal), caso não tenha sido vítima de violência sexual.

Art. $6^{\circ}$ A quarta fase se encerra com o Termo de Consentimento Livre e Esclarecido, que obedecerá aos seguintes requisitos:

I - o esclarecimento à mulher deve ser realizado em linguagem acessível, especialmente sobre:

a) os desconfortos e riscos possíveis à sua saúde;

b) os procedimentos que serão adotados quando da realização da intervenção médica;

c) a forma de acompanhamento e assistência, assim como os profissionais responsáveis; e

d) a garantia do sigilo que assegure sua privacidade quanto aos dados confidenciais envolvidos, exceto quanto aos documentos subscritos por ela em caso de requisição judicial;

II - deverá ser assinado ou identificado por impressão datiloscópica, pela gestante ou, se for incapaz, também por seu representante legal; e

III - deverá conter declaração expressa sobre a decisão voluntária e consciente de interromper a gravidez. 
Art. 70 Todos os documentos que integram o Procedimento de Justificação e Autorização da Interrupção da Gravidez nos casos previstos em lei, conforme Modelos dos Anexos I, II, III, IV e V desta Portaria, deverão ser assinados pela gestante, ou, se for incapaz, também por seu representante legal, elaborados em duas vias, sendo uma fornecida para a gestante

Art. $8^{\circ}$ Esta Portaria entra em vigor na data de sua publicação.

Art. 90 Fica revogada a Portaria no 1145/GM, de 7 de julho de 2005, publicada no Diário Oficial da União n 130, de 8 de julho de 2005, Seção 1, página 31. 
Anexo B

\section{(IDENTIFICAÇÃO DO SERVIÇO)}

\section{TERMO DE RELATO CIRCUNSTANCIADO}

$\mathrm{Eu}$, brasileira, anos,

portadora do documento de identificação tipo declaro que no dia , do mês do ano de $\mathrm{n}^{\circ}$ no endereço (ou proximidades - indicar ponto de referência) bairro cidade fui vítima de crime de violência sexual, nas seguintes circunstâncias:

Em caso de agressor(s) desconhecido(os)

Declaro ainda, que fui agredida e violentada sexualmente por homem(s) de aproximadamente anos, raça/cor cabelos , trajando (cal-

ça, camisa, camisetas, tênis e outros), outras informações (alcoolizado, drogado, condutor do veículo/tipo etc.).

O crime foi presenciado por (se houver testemunha)

Em caso de agressor(a)(s) conhecido(a)(s)

Declaro ainda, que fui agredida e violentada sexualmente por (informação opcional) , sendo meu/ minha (indicar grau de parentesco ou de relacionamento social e afetivo), com anos de idade e que no momento do crime encontrava-se/ou não (alcoolizado, drogado).

O crime foi presenciado por (se houver testemunha) 
É o que tenho/temos a relatar

Local e data:

Nome, identificação e assinatura

\section{TESTEMUNHAS}

\begin{tabular}{c} 
Profissional de saúde \\
Nome, identificação e assinatura \\
\hline Profissional de saúde \\
Nome, identificação e assinatura
\end{tabular}


Anexo C

\section{(IDENTIFICAÇÃO DO SERVIÇO)}

\section{PARECER TÉCNICO}

Em face da análise dos resultados dos exames físico geral, ginecológico, de ultrassonografia obstétrica e demais documentos anexados ao prontuário hospitalar no da paciente , documento tipo $n^{\circ}$

manifesta-se pela compatibilidade entre a idade gestacional e a da data da violência sexual alegada.

Local e data:

Médico

(assinatura e carimbo) 


\section{(IDENTIFICAÇÃO DO SERVIÇO)}

\section{TERMO DE APROVAÇÃO DE PROCEDIMENTO DE INTERRUPÇÃO DA GRAVIDEZ RESULTANTE DE ESTUPRO}

Nesta data, a Equipe deSaúde multidisciplinar do Serviço de do Hospital , avaliou o pedido de interrupção de gestação, fundamentado na declaração de violência sexual apresentada, pela usuária portadora do documento de identificação tipo registro hospitalar $n^{\circ}$ com $\mathrm{n}^{\circ}$ semanas de gestação. Atesta-se que o pedido se encontra em conformidade com o artigo 128 do inciso II do Código Penal, sem a presença de indicadores de falsa alegação de crime sexual. Portanto, APROVA-SE, de acordo com a conclusão do Parecer Técnico, a solicitação de interrupção de gestação formulada pela paciente e/ou por seu representante legal.

Local e data

RESPONSÁVEIS PELA APROVAÇÃO

Equipe multiprofissional:

Carimbo e assinatura

Carimbo e assinatura

Carimbo e assinatura 
Anexo E

\section{(IDENTIFICAÇÃO DO SERVIÇO)}

\section{TERMO DE RESPONSABILIDADE}

Por meio deste instrumento, eu portadora do documento de identificação tipo $n^{\circ}$ , ou legalmente representada por portador (a) do documento de identificação tipo $\mathrm{n}^{\circ} \_$__ assumo a responsabilidade penal decorrente da prática dos crimes de Falsidade Ideológica e de Aborto, previstos nos artigos 299 e 124 do Código Penal Brasileiro, caso as informações por mim prestadas ao serviço de atendimento às vítimas de violência sexual do Hospital NÃO correspondam à legítima expressão da verdade.

Local e data:

Nome, identificação e assinatura 


\section{TERMO DE CONSENTIMENTO LIVRE E ESCLARECIDO}

\section{INTERRUPÇÃO DE GRAVIDEZ RESULTANTE DE VIOLÊNCIA SEXUAL}

Por meio deste instrumento eu, , documento de identificação tipo , no registro hospitalar $\mathrm{n}^{\circ}$ e/ou meu representante legal/responsável documento de identificação tipo $\mathrm{n}^{\circ}$ , em conformidade com o Artigo 128, inciso II do Código Penal Brasileiro, exerço-o direito de escolha pela interrupção da gestação de forma livre, consciente e informada.

Declaro que estou informada da possibilidade de manter a gestação até o seu término, sendo-me garantido os cuidados de pré-natal e parto, apropriados para a situação; e das alternativas após o nascimento, que incluem a escolha de permanecer com a criança e inseri-la na família, ou de proceder com os mecanismos legais de doação.

Declaro, estar esclarecida(os) dos procedimentos médicos que serão adotados durante a realização da intervenção (abortamento previsto em Lei), bem como dos desconfortos e riscos possíveis à saúde, as formas de assistência e acompanhamentos posteriores e os profissionais responsáveis.

Declaro, que me é garantido o direito ao sigilo das informações prestadas, exceto em caso de requisição judicial.

Declaro, outrossim, que após convenientemente esclarecida pelos profissionais de saúde e ter entendido o que me foi explicado, solicito de forma livre e esclarecida a interrupção da gestação atual decorrente de violência sexual, eautorizo a equipe do Hospital aos procedimentos necessários. 
Local e data:

\begin{tabular}{c}
\hline Nome, identificação e assinatura \\
\hline Testemunha \\
\hline Testeme, identificação e assinatura \\
Nome, identificação e assinatura
\end{tabular}




\section{Anexo G}

Republica Federattva do Brasll Ministerio da Saude

\section{SISTEMA DE INFORMAÇÃNO DE AGRAVOS DE NOTIFICAÇÄO}

FCHA DE NOTIFICAÇAO $I$ INVESTIGAÇAO INDIVIDUAL VIOLENCLA DOMÉSTICA, SEXUAL EIOU OUTRAS VIOLENCLAS

Definiçăo de caso: Suspeita ou confirmaçáo de violéncia. Considera-se violéncia como o uso intencional de força física ou do poder, real ou em ameaça, contra si próprio, contra outra pessoa, ou contra um grupo ou uma comunidade que resulte ou tenha possibilidade de resultar em lesáo, morte, dano psicológico, deficiência de desenvolvimento ou privaçáo (OMS, 2002). Atencäo: Em casos de suspeita ou confirmaçäo de violência contra crianças e adolescentes, a notificaçäo deve ser obrigatória e dirigida a0s Conselhos Tutelares elou autoridades competentes (Juizado da Infáncia e Juventude elou Ministério Público da localidade). de acordo com o art. 13 da Lei no 8.069/1990 - Estatuto da Criança e do Adolescente. Também sảo considerados de notificação compulsória todos os casos de violència contra a mulher (Decreto-Lei no 5.099 de 03/06/2004, Lei no 10.778/2003) e maus tratos contra a pessoa idosa (artigo 19 da Lei no 10.741/2003).

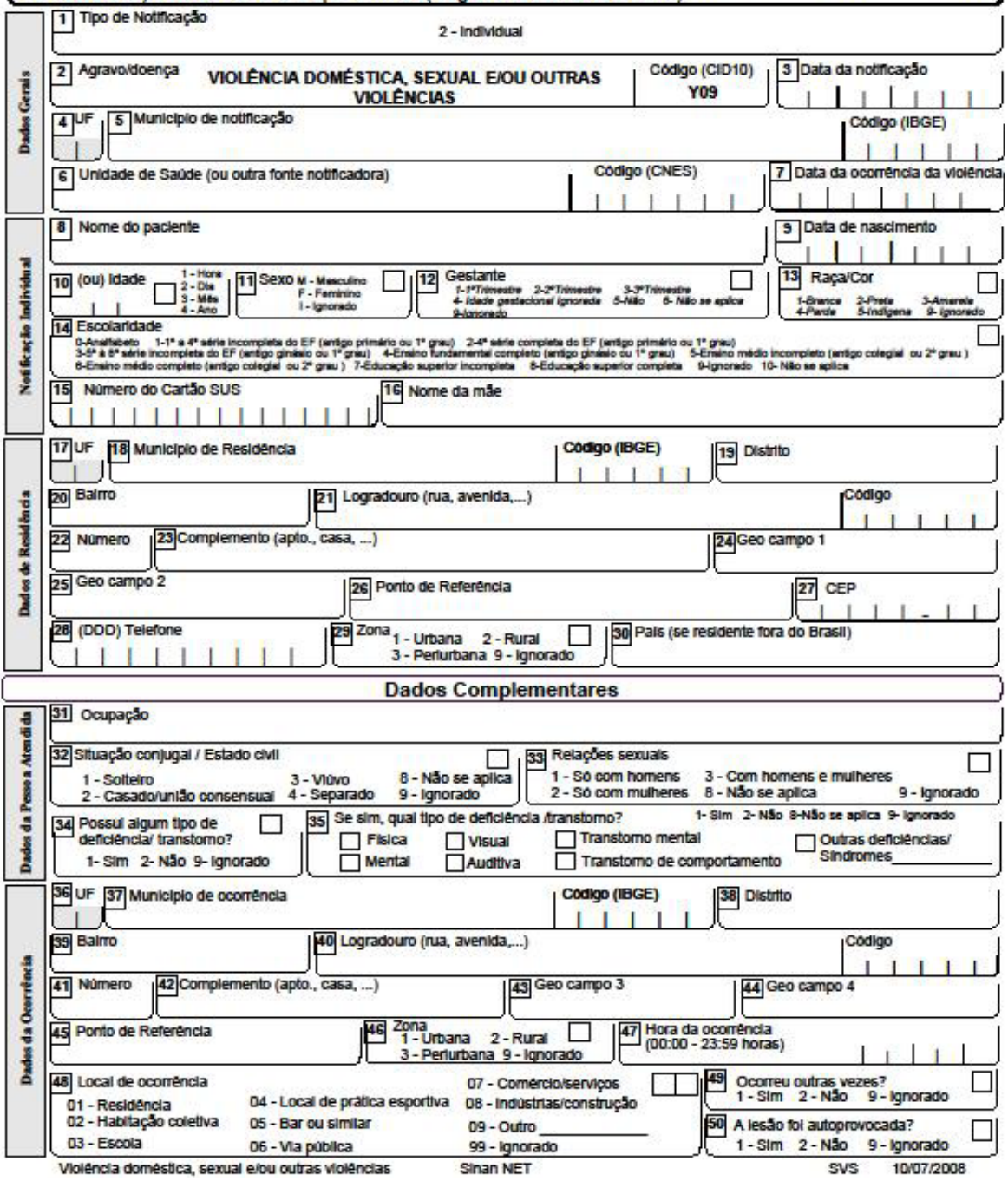




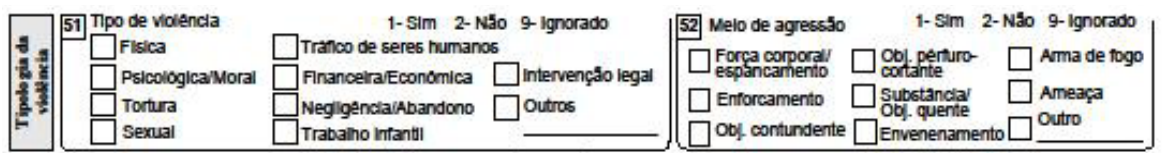

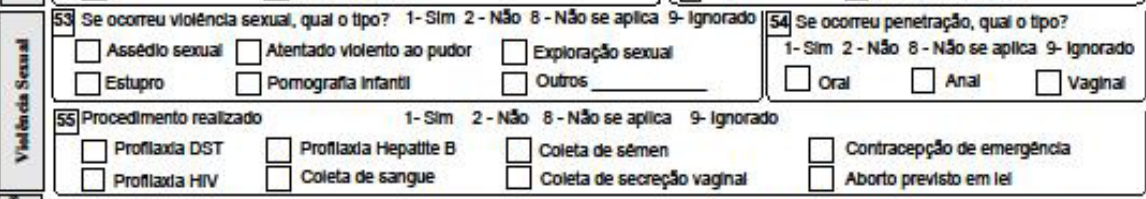

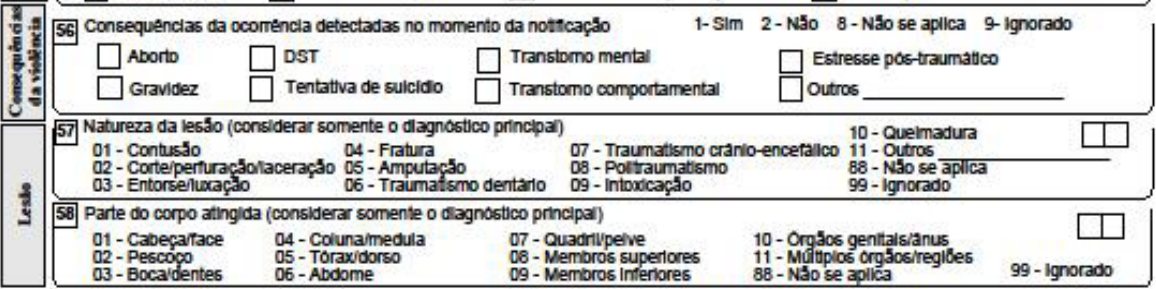

59 Nümero de, E0 vinculo / grau de parertesco com a pessos stendida 1-Sim 2-Năo 9- Ignorado

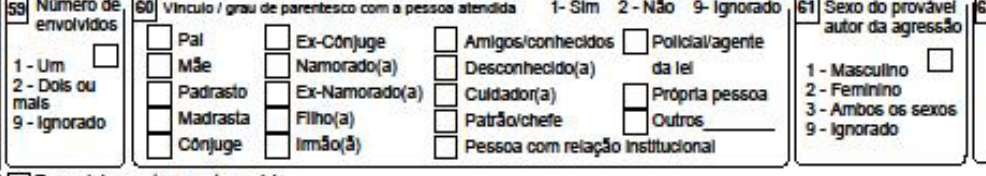

Encaminnamento no setor saude

1 -Encaminhamento ambulatorial $\quad 2$-internaçăo hospitalar 8 -Náo se aplica $\quad 9$-ignorado $\quad \square$

54 Encaminhamento da pessoa atendida para outros setores 1- SIm 2-N5o g- Ignorado
$\square$ conselho Tulelar (Crlança/Adolescente)
$\square$ Delegacla de Atendimento a MulherDEAM

$\square$ Centro de Referencla da Mulher

$\square$ Vara da Intancla / Juventude

$\square$ Casa Abrigo

$\square$ Delegacla de Prot. da Criança e do Adolescente

Centro de Referencla da

$\square$ Programa Sentnela

$\square$ Outras delegaclas

$\square$ Ministerio Poblco

$\square$ Assistencla SocialCREAS
$\square$ Institusto Medico Legal (IML)

Vlolencla Relacionada ao Trabalho

1-SIm 2-Năo 9 - Ignorado

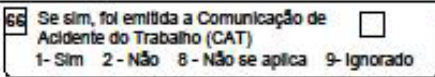

Outros

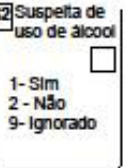

68 Classincaça tinal

1 - Confirmado

2-Descartado

3 -Provavel

8 - inconclusivo
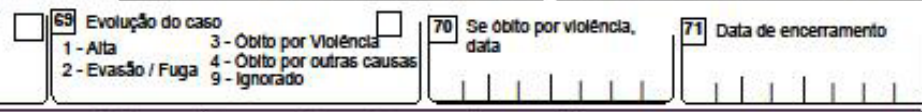

Informaçöes complementares e observações

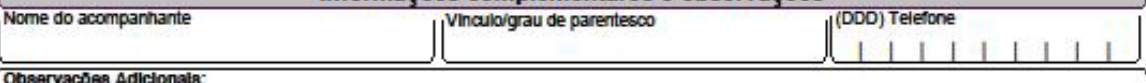

Observaçoes Adictonals:

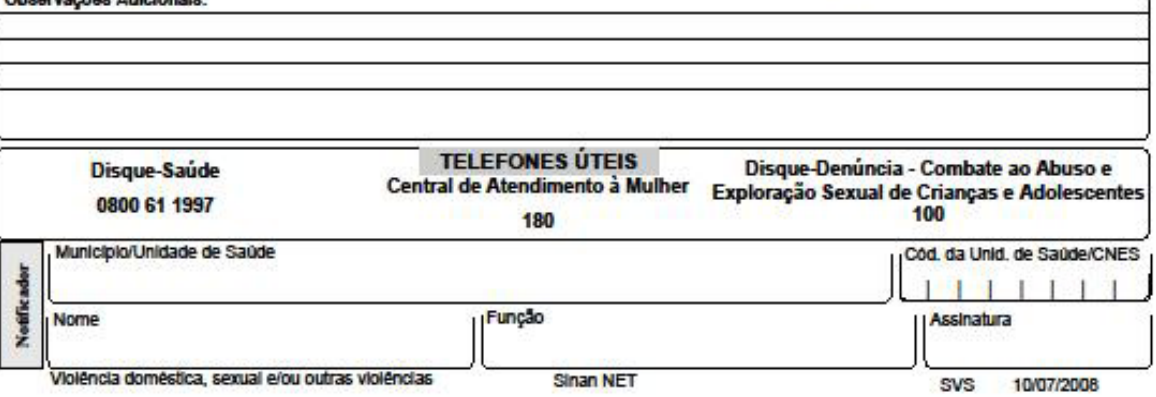





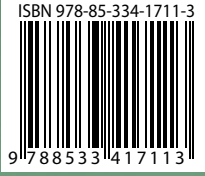

Ouvidoria do SUS

136

Biblioteca Virtual em Saúde do Ministério da Saúde www.saude.gov.br/bvs

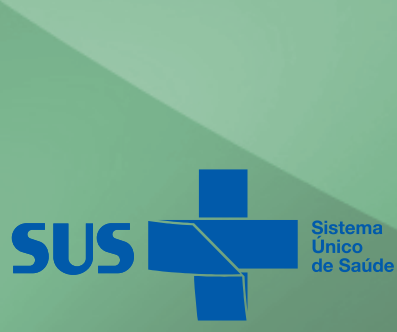

Ministério da Saúde

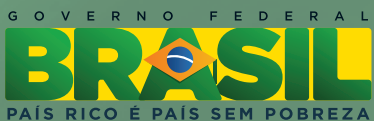

